\title{
Strong organisations in weak states : atypical public sector performance in dysfunctional environments
}

Citation for published version (APA):

Abah, J. (2012). Strong organisations in weak states : atypical public sector performance in dysfunctional environments. [Doctoral Thesis, Maastricht University]. Boekenplan.

https://doi.org/10.26481/dis.20120620ja

Document status and date:

Published: 01/01/2012

DOI:

10.26481/dis.20120620ja

Document Version:

Publisher's PDF, also known as Version of record

\section{Please check the document version of this publication:}

- A submitted manuscript is the version of the article upon submission and before peer-review. There can be important differences between the submitted version and the official published version of record.

People interested in the research are advised to contact the author for the final version of the publication, or visit the DOI to the publisher's website.

- The final author version and the galley proof are versions of the publication after peer review.

- The final published version features the final layout of the paper including the volume, issue and page numbers.

Link to publication

\footnotetext{
General rights rights.

- You may freely distribute the URL identifying the publication in the public portal. please follow below link for the End User Agreement:

www.umlib.nl/taverne-license

Take down policy

If you believe that this document breaches copyright please contact us at:

repository@maastrichtuniversity.nl

providing details and we will investigate your claim.
}

Copyright and moral rights for the publications made accessible in the public portal are retained by the authors and/or other copyright owners and it is a condition of accessing publications that users recognise and abide by the legal requirements associated with these

- Users may download and print one copy of any publication from the public portal for the purpose of private study or research.

- You may not further distribute the material or use it for any profit-making activity or commercial gain

If the publication is distributed under the terms of Article $25 \mathrm{fa}$ of the Dutch Copyright Act, indicated by the "Taverne" license above, 


\title{
Strong Organisations in Weak States
}

\author{
Atypical Public Sector Performance in \\ Dysfunctional Environments
}

\section{DISSERTATION}

to obtain the degree of Doctor at the Maastricht University, on the authority of the Rector Magnificus

Prof.dr. G.P.M.F. Mols

in accordance with the decision of the Board of Deans,

to be defended in public on Wednesday 20 June, 2012, at 16:00 hrs.

\author{
by \\ Joe Abah
}





\section{Promoters}

Prof. Friso den Hertog

Prof. L. Adele Jinadu, professor of Political Science, University of Lagos, Nigeria

\section{Assessment Committee:}

Prof. dr. Maarten Verkerk (chairman)

Prof. Alex Gboyega, professor of Political Science, University of Ibadan, Nigeria

Dr. Haakan Edstrom, senior researcher, Folke Bernadotte Academy, Sweden.

Dr. Mindel van de Laar 
To say it once more: today I find it an impossible book: I consider it badly written, ponderous, embarrassing, image-mad and imageconfused, sentimental, in places saccharine to the point of effeminacy, uneven in tempo, without the will to logical cleanliness, very convinced and therefore disdainful of proof, mistrustful even of the propriety of proof, a book for initiates, "music" for those addicted to music, those who are closely related to begin with on the basis of common and rare aesthetic experiences, "music" meant as a sign of recognition for close relatives in arbutus [in the arts]an arrogant and rhapsodic book that ought to exclude right from the beginning the profanum vulgus [the profane crowd] of "the educated" even more than "the mass" or "folk." Still, the effect of the book proved and proves that it had a knack for seeking out fellow-rhapsodizers and for luring them on to new secret paths and dancing places (Nietzsche, 2000, p. 3).

(C) 2012 Joe Abah

All rights reserved. No part of this publication may be reproduced, stored in a retrieval system, or transmitted in any form, or by any means, electronic, mechanical, photocopying, recording or otherwise, without the prior permission in writing from the author.

Cover image taken from "CR!SIS, The State of the Nigerian Educational System and the Agenda for Reform", presentation of the Presidential Forum on the Education Sector, Federal Ministry of Education, Nigeria, October 28,

2006. The image shows that despite the seemingly impossible chaos, movement is still possible and destinations can still be reached.

ISBN 9789086662593

Published by Boekenplan, Maastricht. 


\section{Acknowledgments}

Completing this dissertation has been a challenging but rewarding endeavour. I have probably read more in the three years that it has taken me to complete it than I did in all previous academic studies put together. Given that my first two degrees are in Law, and that I have professional certificates to practice law in two different countries (obtained by examination), that is saying something.

I owe a huge debt of gratitude to various people, but constraints of time and space will not enable to me to mention every one of them by name. The first and most important person whom I must mention is my darling wife, Kemi, who has always believed, and made me believe, that I could do the seemingly impossible. If the truth be told, doing a $\mathrm{PhD}$ is a selfish and selfrewarding endeavour, especially when its prospects of enhancing immediate career prospects are unclear. I am grateful that Kemi gave me the encouragement, support and space to see it through to the end. I am also grateful for the patience of my daughters, Nnenna and Ola, and my stepsister, Stella, who were denied my full attention while I was on this journey. I am also grateful to my parents and siblings for their support. My father always wanted me to be a medical doctor but I chose a different path. I hope that being a doctor of another sort will help to make up for any disappointment he may have had.

My special gratitude goes to Professor Ladipo Adamolekun who encouraged, supported and guided me throughout the process of this dissertation. He kindly wrote the academic reference that formed part of my application to enrol on the $\mathrm{PhD}$ course, guided me through the development of my research proposal and offered constructive criticism and guidance on all chapters. He also helped to identify one of my supervisors, and bought me several books during the 3 year period. Several PhD holders have claimed him as their mentor. I want to be atypical and claim him as my senior friend. I am also grateful to Professor Dele Olowu for his guidance and support.

I must recognise the contribution of Dr. James Morton, former Managing Director of HTSPE Limited, who was the first person to introduce me to the concept of demand. Other HTSPE directors have equally been supportive of 
my research, particularly Jeremy West and Peter Ross, allowing me to combine my work responsibilities with my research in as flexible a manner as possible.

I am grateful to my work colleagues who have contributed in one way or the other to the completion of this dissertation. John Sanchez gave generously of his time when I was his deputy and ensured that I had enough space to complete this work, including doing some of my office work for me on occasions. Mark Walker, when he became my deputy, similarly shielded me from distractions to enable me to complete the final part of the dissertation, and Hadiza Elayo attended many meetings and produced various reports on my behalf. I am also grateful to Chris Perry who taught me how to do a distribution curve and Tim Donaldson who showed me parts of Microsoft Word that I did not know existed. Esther Ogbole worked as my research assistant for about 4 months and provided excellent support with organising focus group discussions and transcribing hours of taped interviews. All other members of the SPARC Abuja team facilitated the research in one way or the other. Other colleagues that I have crossed intellectual swords with include Simon Foot (who introduced me to Realism), Ursula Blackshaw (who taught me how to defend myself against snobbery from quantitative-minded people), Steve Bertram (who introduced me to the work of Judith Tendler), Steve Hallan and Joseph Umoabasi.

Asishana Okauru, Director General of the Nigeria Governors Forum, was a tremendous help in facilitating my interviews at the Federal Inland Revenue Service and the Economic and Financial Crimes Commission. Afeikhena Jerome was instrumental in arranging my interview with President Olusegun Obasanjo.

My friends Chinedu Eze, Victor Mayomi and Sunny Osuagwu have provided me with incredible support. They perhaps know nearly as much about my topic as I now do, given the number of times that I have bounced ideas off them.

I greatly appreciate the professionalism, friendship and support of the staff of the Maastricht Graduate School of Governance. Dr. Mindel van de Laar has been a tremendous help to me, as has Professor Eddy Szirmai. They 
have guided my work from my very first day at the School all the way through. Dr Haakan Edstrom has kindly and enthusiastically read everything that I have put in front of him and offered valuable opinions, advice and support, for which I am grateful. I am also grateful for the support and encouragement of my colleagues from the GPAC 2009 cohort, particularly Nikolas Wyn Myint; Meike van Ginneken, Leny van Oijen, Yulia Krieger, Farida Lada, Laura Addati and Josephine Namusisi.

I am grateful to my supervisors, Professors Friso den Hertog and Adele Jinadu for their guidance, friendship and support. It has been a privilege to learn at their feet. Any positive comments about this work are attributable to their guidance. Any negative ones are attributable to me.

I would also like to thank the Assessment Committee, Prof. Verkerk, Prof. Gboyega, Dr van de Laar and Dr Edstrom, for their constructive criticisms and guidance which has greatly improved this dissertation.

My Maastricht coach, Jessica Slijkhuis, is worthy of special mention. She helped to open my mind (or is partly to blame for it) and supported me to take in other perspectives that may be different from mine. The ultimate proof of Jessica's success was the fact that I spent my own money to buy Adolf Hitler's Mein Kampf, for which I got very strange stares indeed on the London Underground while I read it!

Finally, I have interviewed a number of amazing people during the course of this dissertation. The interview with President Obasanjo had a profound effect on me. I had been warned that he would angrily throw me out at some point, given the line of questioning that my empirical work inevitably had to follow. Instead, he invited me to breakfast after I had exhausted my semi-structured interview questions and carried on engaging intellectually for a total of 3 hours. I am grateful to Ayo Aderinwale for helping to organise the interview. I found the interaction with Bill Gates enriching and was struck by the humanity of the man, and his seeming ability to only see solutions rather than problems. I am also grateful to all the organisations that I studied, particularly the ones that knew that my dissertation may be critical of the way that they do things. They still cooperated openly and honestly in my quest for answers, in the hope that they too would learn something. This is commendable and I am grateful for their courage and 
honesty. Meeting with Ifueko Omoigui-Okauru, Nuhu Ribadu, Dora Akunyili, Ibrahim Lamorde, Donald Duke, Joseph Odumodu, Elvis Oglafa, Amina az Zubair, Frank Nweke, Jnr., my old friend Rueben Abati and other patriotic Nigerians was a rare privilege. The focus group discussions and interviews with junior and mid-level officers at the Economic and Financial Crimes Commission and the Independent Corrupt Practices Commission filled me with hope for Nigeria. Before I left him, President Obasanjo made me promise that I would not lose hope in Nigeria despite the challenges that the country has. I can confirm that it is not in my nature to lose hope. My dissertation itself is a statement of informed hope. 


\section{Contents}

Acknowledgments.................................................................................................ii

Contents

List of Figures ............................................................................................................. xii

List of Tables ...............................................................................................ii

Chapter 1 Functional Organisations in Dysfunctional States ................1

1.1 The Context: A brief history of the Nigerian Public Service ............1

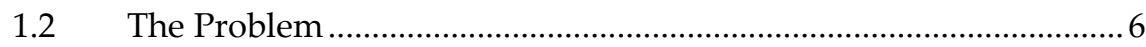

1.3 The Phenomenon of Strong Organisations in Weak Governance Environments....................................................................................... 10

1.4 Explaining the Phenomenon............................................................ 11

1.5 Research Questions and Dependent and Independent Variables 13

1.6 The Approach of the Study ……………………………………......... 19

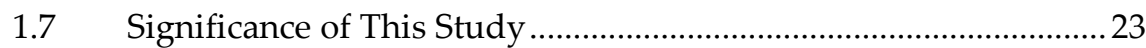

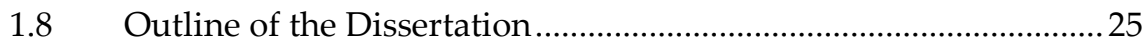

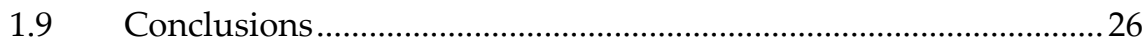

Chapter 2 Theoretical Concepts: In the Guise of a Miracle ...................28

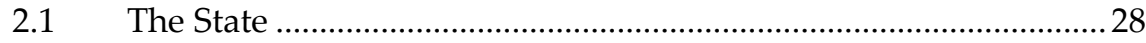

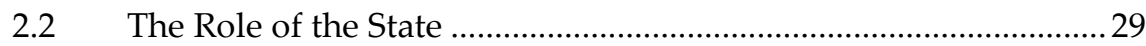

2.3 Globalisation and the State ……………………................................

2.4 The African State ................................................................................... 32

2.5 Public Sector Organisations and the Role of the State .....................36

2.6 Institutions and Public Sector Organisations ................................... 40

2.7 Overcoming the Fatalism of Institutional Theories ........................... 44 
2.8 Demanding Better Public Service Delivery ................................. 48

2.9 Limitations of Current Literature............................................. 51

2.10 Conceptual Framework and Link to Research Design and

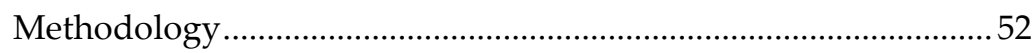

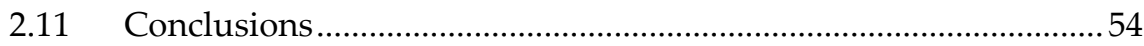

Chapter 3 Research Design and Methodology: Organised Scepticism.. 56

3.1 Research Approach ......................................................................... 56

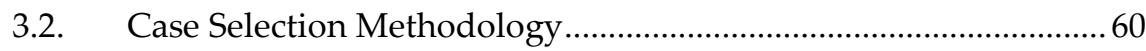

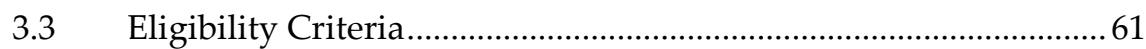

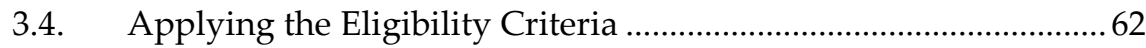

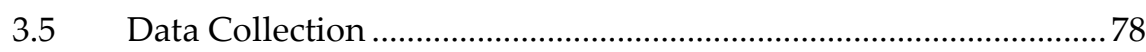

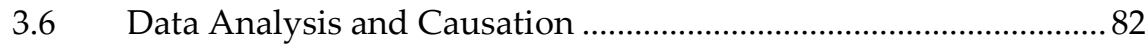

3.7 Indicators for Testing the Existence of Demand .......................... 83

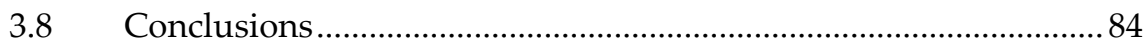

Chapter 4 Anti-Corruption: Swimming Against the Tide.................... 86

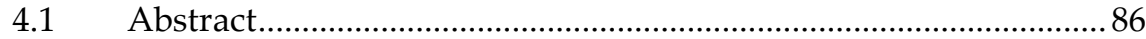

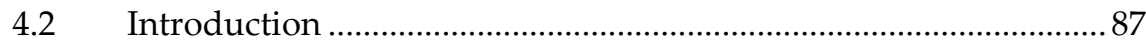

4.3 The Independent Corrupt Practices and Other Related Offences Commission (ICPC) .................................................................... 91

4.3.1 Brief History of ICPC ........................................................... 91

4.3.2 Functions of ICPC ................................................................... 93

4.3.3 Mode of Operation................................................................... 94

4.4 The Economic and Financial Crimes Commission (EFCC) ...........96

4.4.1 Brief History of EFCC................................................................96

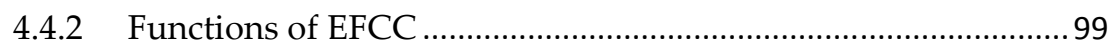

4.4.3 Mode of Operation.................................................................. 101 
4.5 Application of Dependent Variable............................................... 102

4.6 Application of Explanatory Variables ............................................. 104

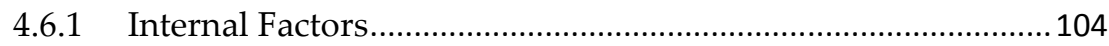

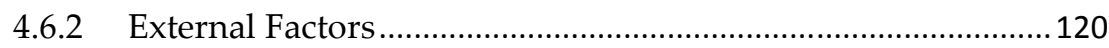

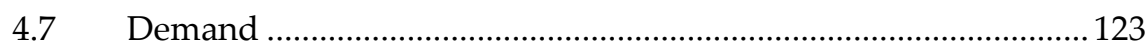

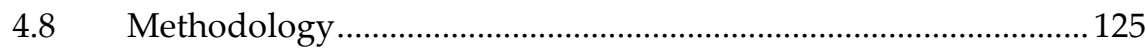

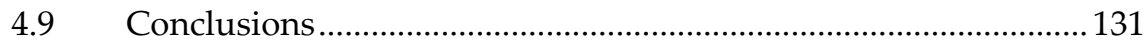

Chapter 5 Regulatory Quality: Against the Odds ...................................133

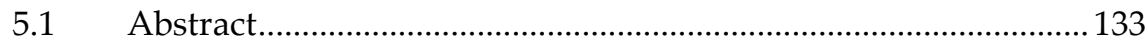

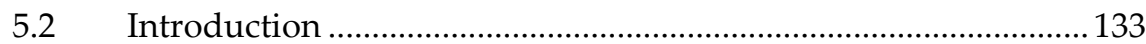

5.3 The Standards Organisation of Nigeria (SON) …………….......... 140

5.3.1 Brief History of SON ............................................................. 140

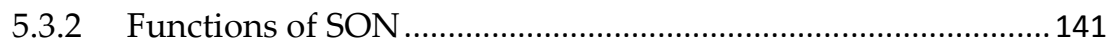

5.3.3 Mode of Operation...................................................................... 142

5.4 The National Agency for Food and Drugs Administration and

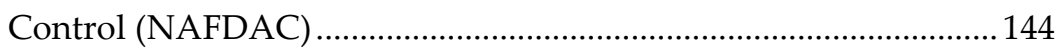

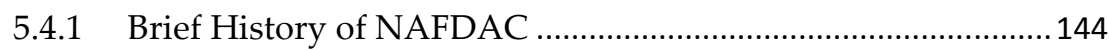

5.4.2 Functions of NAFDAC ........................................................... 146

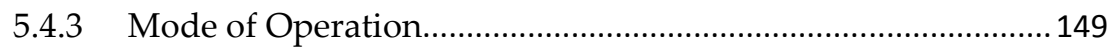

5.5 Application of Dependent Variable................................................... 149

5.6 Application of Explanatory Variables ……………………………..... 151

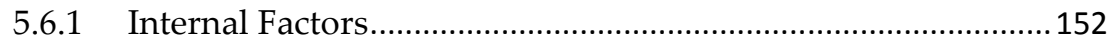

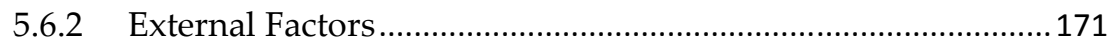

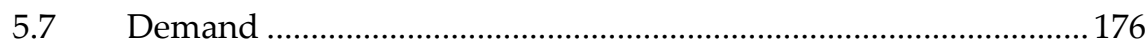

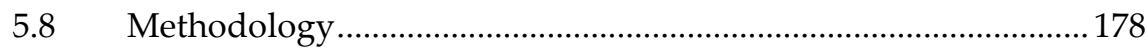

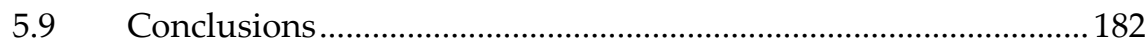

Chapter 6 Revenue Administration: Giving To Caesar .........................184 


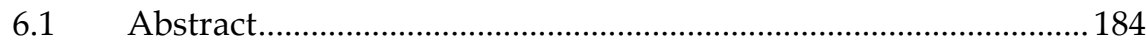

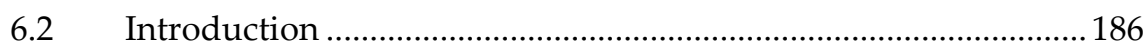

6.3 The Nigeria Customs Service ………………….......................... 188

6.3.1 Brief History of the NCS .......................................................... 188

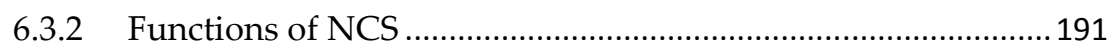

6.3.3 Mode of Operation................................................................... 192

6.4 The Federal Inland Revenue Service (FIRS) …………………........194

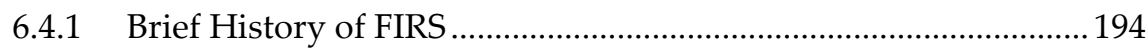

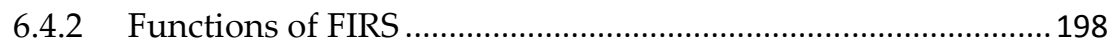

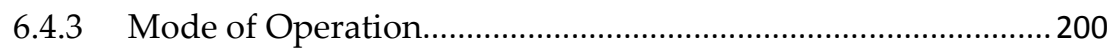

6.5 Application of Dependent Variable..................................................203

6.6 Application of Explanatory Variables ............................................20

6.6.1 Internal Factors.......................................................................... 208

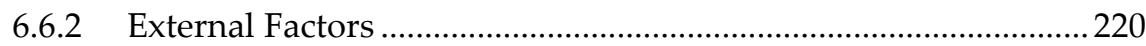

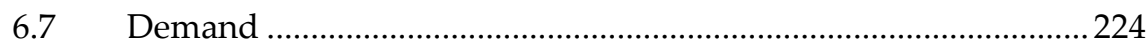

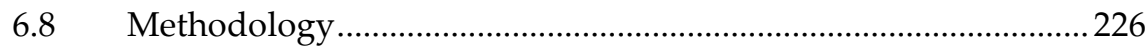

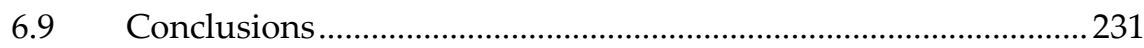

Chapter 7 Islands of Performance in a Sea of Underperformance.... 234

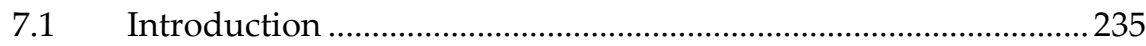

7.2 Application of the Dependent Variable ......................................... 237

7.3 Application of Explanatory Variables …………………………......243

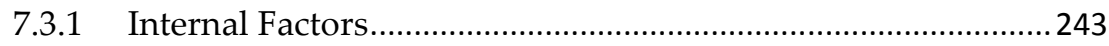

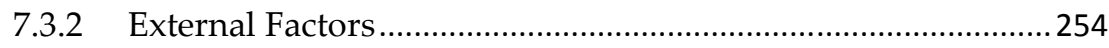

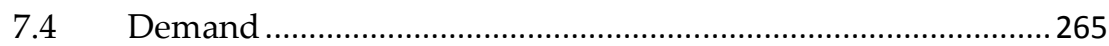

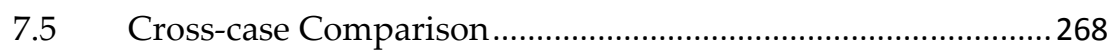

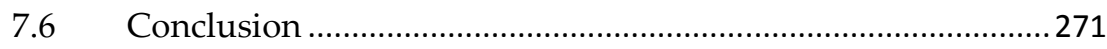


Chapter 8 Towards a New Theory for Overcoming Institutional

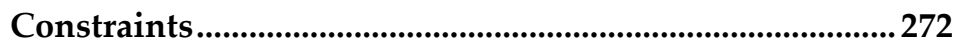

8.1 Brief Summary of Empirical Findings …………………………....22

8.2 Building Theory from Case Study Research....................................22

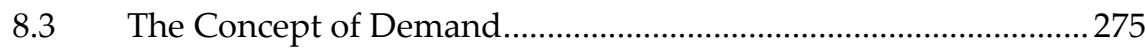

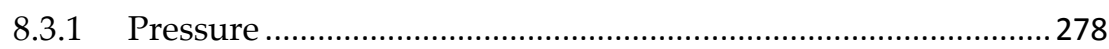

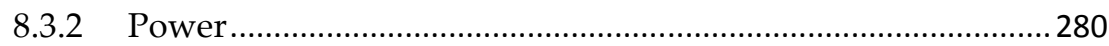

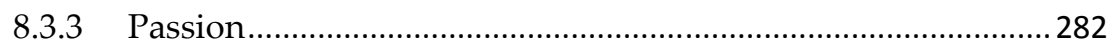

8.4 The Theory of Convergent Demand ………………………….......... 285

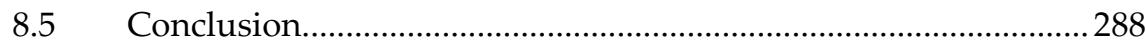

Chapter 9 Unfinished Business ..................................................................... 290

9.1 Contributions to Knowledge …………………………………........291

9.2 Limitations and Opportunities for Further Research.....................297

References and Additional Information .......................................................301

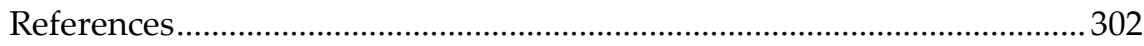

Summary in Dutch/ Samenvatting ...............................................................329

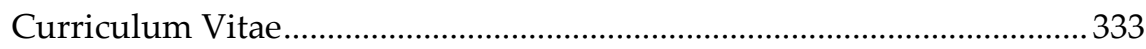

Maastricht Graduate School of Governance Dissertation Series ..............335 


\section{List of Figures}

Figure 1: Relationship of Citizens, Politicians and Public Servants................39

Figure 2: Conceptual Framework ...................................................................53

Figure 3: Case Selection Methodology .............................................................. 63

Figure 4: Perceptions of Effectiveness, Confidence and Corruption in

Government Institutions and Agencies in Nigeria ..........................................64

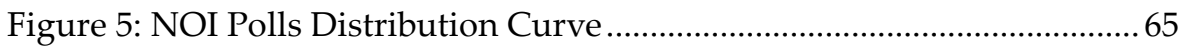

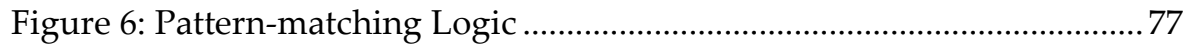

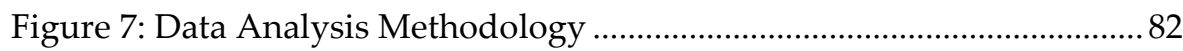

Figure 8: Nigeria's Corruption Perception Index 1996-2010 ........................... 88

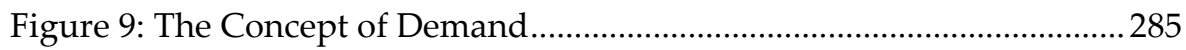




\section{List of Tables}

Table 1: Actual Performance of FIRS and NCS............................................... 75

Table 2: Interview Approach and Epistemological Interest............................ 81

Table 3: Summary of Government Efforts at Fighting Corruption, 1960-2009

Table 4: Nigeria's Score on the Corruption Perception Index, 1996-2010 .... 90

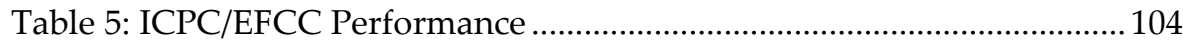

Table 6: ICPC/EFCC Funding 2008-2010 .........................................................112

Table 7: Anticorruption Case Study: Comparison with Methodological Plans 128

Table 8: Budgetary Appropriations to SON and NAFDAC …………..........159

Table 9: Comparison of Pay between SON/NAFDAC and mainstream Civil

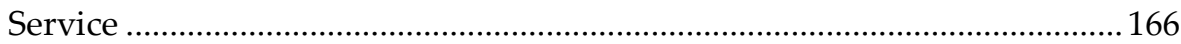

Table 10: Regulatory Quality Case Study: Comparison with Methodological

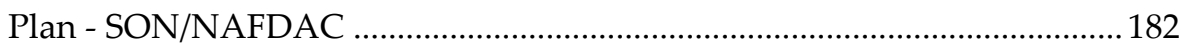

Table 11: Actual Performance of NCS 2004-2011 ............................................ 205

Table 12: Actual Performance of FIRS 2004-2011 ……………………........ 207

Table 13: Revenue Administration: Comparison with Methodological Plan -

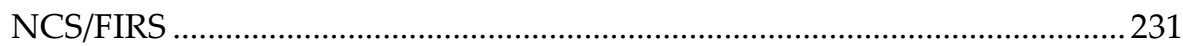

Table 14: Cross-case Comparison of Atypical Performers .............................. 271 



\section{Chapter 1 Functional Organisations in Dysfunctional States}

Impenetrable, incomprehensible to outsiders, Lagos survives. It pulsates. It grows. It works. So does Nigeria. By any law of political or social science it should have collapsed or disintegrated years ago. Indeed, it has been described as a failed state that works (Dowden, 2009, p.440).

The new always happens against the overwhelming odds of statistical laws and their probability, which for all practical, everyday purposes amounts to certainty; the new always appears in the guise of a miracle (Arendt, 1998, p.198).

This chapter sets the context of my research. It highlights the various constraints to good public service delivery in developing countries, but shows that, despite the daunting constraints, some organisations are still managing to deliver the outputs that they were set up to deliver. It also sets out the research question that the study seeks to answer, the dependent and independent variables used, the initial hypotheses advanced, and the contributions that the research will make to existing literature.

\subsection{The Context: A brief history of the Nigerian Public Service}

Prior to independence in 1960, Nigeria operated a Westminster model of public management under the British colonial administration. Although a truly Nigerian public service dates back to 1954, the service was still in transition from a colonial to an indigenous one by the time of the country's first military coup in 1966 (Olaopa, 2009, p.132). 
At the turn of independence in 1960, the Nigerian public service was widely regarded to be one of the best in the Commonwealth (Olaopa, 2010, p.195). The departing premier of Western Nigeria, Chief Obafemi Awolowo, said of the civil service:

Our civil service is exceedingly efficient, absolutely incorruptible in its upper stratum, and utterly devoted and unstinting in the discharge of its many and onerous duties (quoted in Adamolekun, 2003, p.60).

However, aberrations such as civil war, military dictatorships, endemic corruption and crippling debt have systematically eroded the capacity and competence of the public sector to fulfil the role for which it was originally designed. Military dictatorships have engendered a norm of bypassing dueprocess and accountability in favour of arbitrariness, unpredictability, selfinterest, ethnicity and lack of respect for the rule of law. Corruption became a way of life, and recruitment into the public service a form of reward for political jobbers and government sympathisers. In 2000 when Nigeria marked its $40^{\text {th }}$ anniversary, it was rated as the most corrupt country in the world (Transparency International, 2000).

Although the military government left in 1999, after more than 30 years, the problems that they created for the Nigerian public service did not leave with them. By 1999, the civil services at the Federal, State and Local Government levels were fundamentally weak and widely regarded as politicised, corrupt, demoralised and inefficient. In 30 years, the public services had "[...] metamorphosed from a manageable, compact, focused, trained, skilled and highly-motivated body into an over-bloated, lop-sided, ill-equipped, poorly paid, rudderless institution, lacking in initiative and beset by loss of morale, arbitrariness and corruption" (Federal Government of Nigeria, 2008, p.2).

The functions of ministries are unclear and many deliver little or no services. The emphasis can appear to be on the award of contracts for capital projects (and the resultant rent-seeking), with little interest in maintenance or sustainability. The public service is littered with parallel organisations created by successive governments to perform normal bureaucratic functions. Once the government that created them leaves 
office, they become operationally redundant but remain on the payroll. This means that the government wage bill is very heavy. Consequently, wages are low and the government and the public servants trade accusations about this: "public servants do not deliver, so deserve a low wage" versus "public servants lack the motivation to deliver because of the low wage". However, the opportunity for rent-seeking and the privilege of exercising state power means that the rate of staff turnover is extremely low. Indeed, many public servants falsify their birthdates in order to stay longer than the mandatory retirement age of 60 years. There has also been an embargo on recruitment (at least on paper), which means that fresh talent is not entering the service. The workforce is aging and there do not appear to be any thought-through succession plans.

Any sort of training is often just an opportunity to earn generous duty tour allowances to supplement wages, rather than an attempt to learn anything that will usefully be applied in the workplace. Managers have little control over the officers in their organisations and little say in their recruitment, promotion or discipline. The human resource management functions are centralised and staff are pooled and posted arbitrarily to different organisations every few years. Therefore, there is little or no professionalism in discrete job functions. Corruption is rife and any attempt at discipline is thwarted by ethnic and religious sentiments.

The current 1999 Constitution of Nigeria (Federal Government of Nigeria, 1999) has further (purposely or inadvertently) contributed to the problems of the public service. For instance, Sections 14(3) and 14(4) enshrine a principle of "Federal Character" which aims to promote the fair representation of all parts of the country in public appointments, but, unfortunately, this has often been used to sacrifice merit at the altar of representation. The Constitution (Section 7 of the Third Schedule) also centralised all recruitment, promotion and discipline within a Federal Civil Service Commission, which has suffered serious credibility problems (Olaopa, 2008, p. 236). There are frequent allegations that the Commission promotes a sectional agenda in its recruitment practices, runs a money-forpromotion racket, and refuses to sanction erring officers.

Performance Management in any sense of the word is virtually non-existent in the Nigerian public service and what exists is manipulated to ensure that it is virtually impossible to assess performance and seek improvement. 
Although public service delivery in Nigeria has been assessed to be 'nonexistent' (Thomson, 2004), it is usual for 99.9\% of civil servants to score 99.9\% out of a possible 100 in their Annual Performance Evaluation Reports. The Government itself acknowledges that the Federal Civil Service of Nigeria currently has no effective performance management system that motivates excellence, result achievement and accountability, whether at corporate or individual levels (Federal Government of Nigeria, 2008, p. 63).

Since colonial times, attempts have been made at major administrative reforms. The Udoji Reform of 1974 recommended the adoption of new management techniques, such as Management-by-Objectives and Programme and Performance-based Budgeting, and higher remuneration packages commensurate with that of the private sector. The military government of the day chose to implement the increase in wages, but not the new management techniques. The 1988 civil service reform programme, known as the Dotun Phillips Reforms, took away the power of permanent secretaries as accounting officers of their ministries and vested that power in ministers. It completely politicised the role of the permanent secretary and tied the tenure of permanent secretaries to that of the administration which appointed them. This effectively destroyed the independence of the civil service and entrenched a culture of arbitrariness that flowed from the military government of the day. The Ayida Reform of 1995 reversed the tenets of the 1988 reforms. It brought back the permanent secretary as the accounting officer in the ministry and restored the post as a career, rather than political, appointment. However, beyond reversing the 1988 initiatives, it did not move the service much further forward in terms of rejuvenation and transformation. (Olaopa, 2009, pp. 134-141).

When democratic rule returned in 1999, serious attempts were made to renew the public service and place it within the context of a wider government reform agenda. The main thrusts of the reform efforts were to modernise core operations using information and communication technology, increase the accountability of public servants to citizens, reduce waste and inefficiency, consolidate various allowances and fringe benefits into salaries, computerise payrolls and introduce a contributory pension scheme (Olaopa, 2010, pp.209-211). However, the reforms were led by people who were deeply suspicious of the ability of the civil service to renew itself. There was, therefore, a strong attempt to force certain 
initiatives through, rather than to win hearts and minds. It did not help that the first major initiative associated with the reforms was a large-scale redundancy exercise, mostly at the lower cadres of the service. As is the practice of civil servants worldwide, they tolerated the changes they could and simply waited out the government in power. The new practice of selecting a permanent secretary from each state, rather than making appointments purely merit-based, also means that permanent secretaries are still, in effect, political appointees.

In 2008, a comprehensive programme of reforms was articulated in a "National Strategy for Public Service Reforms". Its vision is "a world-class public service delivering government policies and programmes with professionalism, excellence and passion" (Federal Government of Nigeria, 2008 , p. xi). Three years since the completion of the strategy, implementation has not commenced. Instead, in 2009, a new directive was implemented limiting the tenure of permanent secretaries and directors to eight years. The pay of permanent secretaries increased to about ten times that of the directors immediately below them. A new civil service training institution was also established (despite the fact that one already existed), but, although all buildings have been completed and the college commissioned, very little use has been made of the institute since its commissioning three years ago.

The practices from the military era and the processes, legislations and rules (formal and informal) that have developed over the years have evolved into a powerful 'culture of non-performance' which is understood, entrenched and fiercely protected. It often brings any new initiative, no matter how well-conceived, to its knees, and is affectionately known as the "Nigerian Factor".

All things bright and beautiful

All creatures great and small

NIGERIA DESTROYS THEM ALL (author unknown, 2011).

It is within this dysfunctional context that this research is set. I have deliberately, but accurately, I hope, painted the Nigerian public service in 
the worst possible light to make the following point: Given the bleak institutional picture painted in this section, and going by known institutional theories, nothing should work. However, some organisations do. Why and how?

\subsection{The Problem}

This research explores the conditions under which public sector organisations can achieve atypical performance in a dysfunctional environment. In this research, a dysfunctional environment is defined as one in which the incentives for public sector organisations to deliver services to citizens are perverse. "Atypical" is used here in the sense of better-than-the-norm, rather than worse-than-the-norm. There is a dearth of comparable performance data in many developing countries, as any sort of performance measurement is the exception, rather than the rule. In determining the norm and what is better than the norm, I have sought to select those organisations that are 1 standard deviation from the mean where there is comparable statistical data, even though that data may initially be from perception surveys only. I have then gone further to ascertain actual performance against targets and mandates to confirm that they are indeed better than the norm. My case selection methodology is more fully set out in Chapter 3. "Typical" is used as the "norm", or mean performance where there is comparable statistical data. The term "atypical performance" is used in the context of similar organisations in the same environment and is not used in the sense of 'world-class' or comparability across different environments. It is accepted that what may be assessed as atypically-good or even exceptional performance in one environment may be viewed as normal or even weak performance in another.

A country's public management system comprises the core civil service (ministries), departments, agencies, parastatals, quangos or special purpose bodies, and local authorities. The primary responsibility of public service organisations is to deliver services that the private sector may not deliver at all, or to deliver services to those who cannot afford the market price of the service. Governments recognise the importance of delivering services that 
may not be commercially viable, but that citizens desire and demand (Olowu, 2002, p. 123).

Governance consists of the traditions and institutions by which authority in a country is exercised. It includes the capacity of the government to formulate and implement sound policies, and to deliver, or ensure the delivery of, services to its citizens (World Bank, 2010). The main elements of governance on which there is broad agreement in the literature are rule of law, freedom of expression and association, electoral legitimacy, accountability and transparency, development-oriented leadership and a competent and efficient administration (Adamolekun, 2002, p. 3).

In many countries, governments are unresponsive to their citizens, corrupt, and incompetent, and find it difficult to mobilise resources to deliver services to its citizens (World Bank, 1997, p. 158; 2004, p. 4). Since one of the main functions of any state is to directly deliver services or commission others to do so, states in which the incentives to deliver services are perverse are in effect dysfunctional. Such states are often weak on most of the dimensions of good governance, regardless of the 'theory of State' that it subscribes to: minimal, developmental, social-democratic, collectivised or totalitarian (Heywood, 2002, p. 99).

In good governance environments, elections are fought over competing promises to deliver "the good life" (Talbot, 2007, p. 491). Therefore, much of the literature takes for granted an appetite to improve public sector performance, especially as it assists politicians to deliver on electoral promises. In the United Kingdom, Tony Blair labelled his 2001 victory "A mandate for reform...an instruction to deliver" (Barber, 2007, p. ix). Environments in which the politician feels accountable to the electorate are more conducive for good public sector performance than environments where there is no sense of accountability to the electorate (Adamolekun, 2002, p. 11). Ideally, to deliver on its mandate, the political class will invest in and value the role of the public service; and the public service, in return, will view its role as helping the government of the day to deliver on its mandate and fulfil its electoral promises to the people. 


\section{The Crisis of Governance in Sub-Saharan Africa}

The state of governance in many developing countries is far from ideal. The problem is perhaps more acute in sub-Saharan Africa than in other parts of the developing world. Indeed, the slow development of many African countries is linked to weak governance systems. In a 1989 study, the World Bank stated that:

Underlying the litany of Africa's development problems is a crisis of governance. By governance is meant the exercise of political power to manage a nation's affairs. Because countervailing power has been lacking, state officials in many countries have served their own interests without fear of being called to account [...] Politics becomes personalised, and patronage becomes essential to maintain power. The leadership assumes broad discretionary authority and loses its legitimacy. Information is controlled, and voluntary associations are co-opted or disbanded. This environment cannot readily support a dynamic economy (World Bank, 1989, p.60).

While there have been a few success stories like Botswana, and emerging success stories like Mozambique, Ghana and Cape Verde, the situation described above by the World Bank would be familiar to most African countries.

\footnotetext{
Although Africa is a continent of great diversity, African states have much in common [...] Indeed, what is so striking about the fifty-year period since independence is the extent to which African states have suffered so many of the same misfortunes (Meredith, 2005, p.14).
}

For the purposes of this study, the main "misfortunes" to address are the dysfunctional political, institutional, organisational and sociological systems that impede the delivery of decent public services to the majority of citizens. 


\section{Political Dysfunction}

The political environment in many developing countries is weak when assessed against major elements of good governance, such as electoral legitimacy and accountability. Getting into power often does not depend on ideology, electoral promises or even votes. Some countries are still under dictatorships, and, even in the so-called democracies, elections are hardly ever free and fair and are often hopelessly rigged in favour of a powerful minority. In many developing countries, therefore, accountability to the electorate is not of primary concern, and there are little or no sanctions for poor performance by the public service. This creates a dysfunctional environment for public service delivery in at least two ways:

a. The political class is not accountable to the electorate and therefore has little incentive to deliver good public services. Indeed, they will bypass the public service at every opportunity, weaken it and starve it of resources, so that it is unable to constrain the politician's private pecuniary interests.

b. Public servants do not maintain any loyalty to the government of the day (which they may perceive to be illegitimate). Therefore they would not do anything that would bring credit to the government and, instead, without political leadership, may abandon the course of serving the public and focus on what they can get for themselves and their families. There are therefore no incentives for good performance.

\section{Institutional and Organisational Dysfunction}

Institutional factors have also affected the environment for public service delivery. Our earlier review of the history of the Nigerian public service since independence typifies the situation in many developing countries, particularly in Sub-Saharan Africa. As an example, in many developing countries, certain political, economic, legal and social provisions are in place to try and knit together diverse ethnic and religious groups. Although these are necessary for social cohesion, their application often has a constraining effect on the ability of public service organisations to achieve optimal performance. 


\section{Sociological Dysfunction}

The sociological context of developing countries is important in understanding issues of dysfunction. The dysfunctional institutional and organisational environment described above means that many public servants are risk-averse and not performance oriented. For instance, almost every letter emanating out of the Nigerian civil service starts with "I am directed to inform you..." The primary interest of many public servants can sometimes appear to be looking out for themselves and their family members, rather than delivering services to the public. There is often greater loyalty to people who can advance careers, than to job descriptions (where they exist), organisational priorities or the delivery of services to the public.

\subsection{The Phenomenon of Strong Organisations in Weak Governance Environments}

Despite all the problems described in the preceding section, scattered throughout weak governance countries are public sector organisations that manage to escape the norm of poor performance, despite operating in difficult environments (Leonard, 2008, p. 7). These organisations, sometimes called 'pockets of productivity' in the literature, manage to fulfil their mandates and provide services that are of benefit to the general public.

In some cases, those atypical pockets of productivity perform well for some time and then fade away, others are deliberately and systematically weakened, and yet others flicker into life only when a good leader is in place (Leonard, 2008). However, some organisations have stubbornly refused to flow with the tide of weak performance. They have survived changes in government, policy reversals, internal organisational upheavals, intimidation by the elite, dwindling budgets and changes in personnel, and still manage to perform reasonably well. How these organisations come to be created, how and why they continue to thrive, and the lessons that they offer for wider public sector reform are the subjects of this research. 
It is poignant that the study is set primarily in the context of perhaps one of the most paradoxical countries in Sub-Saharan Africa - Nigeria. It is fabulously naturally-endowed (oil earnings in excess of $\$ 400$ billion since independence, and home to virtually every natural mineral known to man) but with crippling poverty (Ikubaje, 2006; Gillies, 2009); it is a deeply religious country with a near 50:50 Christian/ Muslim population but with a strong belief in animism, witchcraft and magic; it is the most populous black nation on earth but with a small political elite that consumes the majority of the country's resources. In such an environment, nothing should work, but some things do.

Why do some organisations work given all the constraints earlier described? How do they survive even in the most difficult environments? What can other organisations learn from their experiences? And is it possible to lift public sector performance across the board by drawing on the experience of the atypically good performers?

\subsection{Explaining the Phenomenon}

In trying to explain the phenomenon of atypical performance in dysfunctional states, many researchers tend to focus on outlining the characteristics that the organisations that they study possess. The characteristics most usually mentioned include strong leadership, good management, a commitment to staff training and development, effective communication, motivated staff, technical capacity, and a supportive political environment. In describing existing research on the subject, Leonard (2008, p. 3) points out that the literature on the subject has generated a very large number of hypotheses based on the individual organisations that have been studied. He goes on to list more than 60 different propositions which he groups into 5 "mega hypotheses", which are more like propositions than clearly-articulated hypotheses:

- Management and leadership determines an organisation's productivity

- Organisations with some types of functions perform better than those with other functions 
- The productivity that an organisation can achieve depends on the timing and process by which it generates a mixture of benefits and cost for the political elite in society

- The political institutions in an environment will shape what an organisation can achieve

- The underlying political economy in an environment will ultimately shape and overcome all other causal factors and determine what an organisation can achieve.

The first two propositions concern managerial and organisational attributes while the last three focus on the interface between political economy and organisational performance.

What is currently lacking in the literature is research that can evaluate the comparative merit of these different hypotheses. It is likely that all the factors mentioned are important but what is not clear, either from Leonard's inventory or other research, is any sort of hierarchy of the key factors or a binding gel that holds them together.

The main proposition of this study is that, in dysfunctional environments, the most important ingredient for achieving and sustaining atypical public sector performance is demand. I argue that, while all the other causal factors such as management and leadership are important, demand sits on top of the hierarchy or is the amalgam that holds them together, and therefore that the efforts of reformers should be aimed at creating or aligning with the demand for improvement. The demand for improved performance could come from government, the private sector, donors, pressure groups and service users, or from a combination of these sources. Demand is a desire for something backed by the ability and willingness to pay for it or bring it about (Sullivan and Sheffrin, 2003, p. 79). I will continue to develop and explain this concept of demand throughout this dissertation. 


\subsection{Research Questions and Dependent and Independent Variables}

Whatever may lie at the bottom of this questionable book: it must have been a question of the greatest interest and appeal, as well as a deeply personal question [...] (Nietzsche, 2000, p.3)

The research question that this study aims to answer is:

How and why are certain public sector organisations able to achieve atypical performance in dysfunctional environments?

The sub-questions that this research will seek to answer are:

- What are the varying effects of external and internal factors on public sector performance?

- To what extent is the quality of management a determinant of organisational performance? For instance, how do methods of recruitment, promotion, remuneration and discipline affect organisational performance?

- To what extent is the quality of leadership a determinant of organisational performance? For instance, what are the effects of task specificity, clarity of goals and clear accountability lines on organisational performance in dysfunctional environments?

- To what extent is the function of the organisation a determinant of its performance? For instance, to what extent are organisations that function, say, in the anti-corruption field more effective than organisations that function in other fields?

- What other factors determine organisational performance? For instance, why do the elite appear to give up some of their power and allow atypical performance in some cases but not in others and what is the role of societal pressure?

- How can atypical performance in one organisation trigger or create demand for improved performance in other organisations? 
- How can an organisation overcome political and institutional constraints to achieve atypical performance? For instance, under what conditions can organisations sustain atypical performance beyond one political administration?

\section{The Dependent Variable}

The performance of private sector organisations is often measured by one overriding factor - profitability. Profit refers to the making of economic gains for the benefit of the owners of the business. Ideally, it is the total revenue achieved over and above the cost of providing the goods or service, rather than the illegal rents received from the state over and above the illegal rents paid to the state, as can be the case in many developing countries. Rents are illegal payments made or advantages received outside normal economic transactions.

On the other hand, the performance of public organisations is notoriously difficult to measure, since there is not one single overriding measure. This research focuses on the public sector, rather than the private sector. It is pertinent therefore to start by asking the obvious question of what we mean when we speak of performance in government. The meaning of performance will vary depending on the lens through which it is looked at and measuring the performance of public sector organisations (central and local government departments; schools, hospitals, etc) is more difficult and calls for a complex mosaic of indicators (Jackson, 1988; Talbolt, 2007; Boyne, et al., 2006; Fitzgerald and Moon, 1996). However, "if you can't define performance, you can't measure or manage it" (Armstrong and Baron, 1998).

Public sector performance can be evaluated through an assessment of any of the following:

1. Inputs - How much resources are expended to produce a public good or service (the financial resources provided to the organisation, staff costs, materials used, cost of equipment, infrastructure, etc). 
2. Outputs produced by the organisation in relation to inputs - The results that the organisation achieves, such as the number of patients treated in a public hospital, number of diplomas produced by schools, level of internally generated revenue, etc.

3. Outcomes - The overall effect that the outputs have on external stakeholders or wider society, such as improved health of the populace, better-educated citizens, more satisfied customers and users of public services, etc.

It is important to distinguish between Outputs and Outcomes. Outputs refer to immediate results of government activity, and Outcomes refer to the final impacts of those activities. While it is usually reasonable to hold governments to account for outputs, it is often not reasonable to hold them entirely responsible for outcomes, because many other factors beyond government's control may intervene to influence the final impacts on society (OECD, 2009, p.63).

The notion of performance, and whether or not it is satisfactory, only has meaning if actual behaviour (outcomes) is compared with some predetermined target (Jackson, 1988).Therefore, although a comprehensive view of performance would be one that embraces all three interrelated variables: inputs, outputs, and value-added outcomes (Mwita, 2000), this research will focus on Outputs, since it is the best measure of the performance of government organisations. "To argue for better and more extensive measurement of outputs is in no way to dismiss or deny the need for other kinds of measures. Nevertheless, outputs have a special place" (OECD, 2009, p.43). Outputs are the final products of public sector organisations and the tangible things that they deliver to the public, such as school diplomas, licences, grants, tax clearance certificates, surgical operations and postal delivery. The ideal public sector organisation is one that achieves its predetermined outputs, with a given set of inputs, without relying on rents.

For the purposes of this research therefore, the term 'performance' will simply be used to mean the extent to which a public sector organisation has achieved its pre-determined goals with regards to its outputs, given a certain level of inputs. Therefore, if it is mandated to achieve a particular set of outputs (whatever the outputs are), to what extent has it done so, given the inputs it 
has? I will evaluate this by reference to published information on targets, expected outputs or performance indicators.

\section{The Explanatory Variable}

For the purposes of this research the key explanatory variables will be discussed in the context of External and Internal Factors (Owusu, 2005).

External factors that affect organisational performance include:

- Political and policy support which determine what an organisation can feasibly achieve, including autonomy and political interference (Leonard, 2008)

- Institutional factors - including conducive historical choices ("Path Dependence") and the favourable interplay between formal and informal rules to achieve results in a society (North, 1990)

- Clarity of expectations - including task specificity, clear mandate, and clarity of the parameters for assessing success (Grindle, 1997).

Internal Factors that affect an organisation's chances of achieving atypical or better-than-the-norm performance are:

- Leadership: the capacity of someone to direct and energize the willingness of people in social units to take actions to achieve organisational goals (Rainey, 1991, p.157).

- Management: the totality of attributes and functions necessary to run an organisation effectively, including freedom to recruit, a focus on results, merit-based human resource management, staff motivation, and decent pay and conditions.

- Technical capacity: the on-the-job competence and capacity of staff, including the use of technology and innovation, to perform the organisation's core functions (Cohen, 1993).

- A resonance between organisational goals and approaches and public expectations, including creating an 'elite-organisation' image (Tendler, 1997, p. 137). 
I will evaluate the Explanatory Variables by determining to what extent the External and Internal factors (and the interplay between them) apply to each organisation that I study, and consider the extent to which they affect the Dependent Variable (the organisation's performance).

\section{Hypotheses}

In studies such as this one, the hypotheses will often emerge from the evidence arising out of the completed study. Examples are Good to Great (Collins, 2001); On Public Organisations in Ghana: What Differentiates Good Performers from Poor Performers? (Owusu, 2005); The Characteristics of a High Performance Organisation (Waal, 2007); and The Secret of High Performance Organisations (Waal, 2008). Therefore, any hypotheses put forward at this stage is to be regarded only as preliminary propositions. Throughout the study, there will be a constant interplay between proposal and verification (Strauss and Corbin, 1990, p.111). However, the approach used here is not a classic Grounded Theory approach that starts with a blank sheet of paper. Certain initial propositions have been developed from a review of the current literature on the subject, and my own professional experience in the field. These will be developed and refined throughout the course of the study as my understanding deepens, in order to propose stronger hypotheses at the end.

For a start, I will be seeking to build on the following initial hypotheses:

H1: In dysfunctional environments, the prior condition for achieving sustainable atypical public sector performance is demand.

H2: Where there is no demand, organisations in dysfunctional environments will perform typically, or worse; and any atypical performance achieved will be brief and unsustainable.

H3: Where institutional conditions are favourable and organisational conditions are effective, atypical performance is more likely to be achieved and sustained. 
H4: Where institutional conditions are favourable but organisational conditions are ineffective, organisational performance is likely to be typical and any atypical performance will be brief and unsustainable.

H5: Where institutional conditions are unfavourable but organisational conditions are effective, organisational performance is likely to be typical and any atypical performance will be brief and unsustainable.

H6: Where institutional conditions are unfavourable and organisational conditions are ineffective, organisational performance is likely to be typical or worse.

Favourable institutional conditions refer to the external factors previously outlined such as strong political and policy support, the existence of suitable legal and regulatory powers and the clarity of expectations on the organisation. Effective organisational conditions refer to internal factors such as good leadership, good management practices, technical capacity to do the job, and a resonance between organisational activities and public expectations.

My key argument is that it is the existence of demand that catalyses atypical performance. Demand in the context of this argument is the informed desire to bring about change, backed by the resources and the willingness to do so (Sullivan and Sheffrin, 2003). Where there is demand, it will create the environment for the other key causal factors to come into play, take hold and make atypical performance possible. In the absence of demand, the existence of other key causal factors, such as leadership and management, will, on their own, have limited effect on improving performance, and any gains achieved are unlikely to be sustained.

I have used the word sustainable to mean subsisting beyond two tenures of the political and/or contractual leadership cycle. Bebbington and McCourt (2007) suggest that atypical performance should persist for at least one political cycle, and have chosen 10 years. In Nigeria, a government is in 
power for 4 years at a time. Heads of agencies are also appointed for 4-year tenures. In both cases, the tenures are renewable for a further 4 years and no more. Therefore, I have taken 'subsisting beyond two tenures of the political and/ or contractual leadership cycle' to mean lasting beyond 8 years, rather than 10 years. In the context in which this study is taking place, subsistence for 8 years is no mean feat.

\subsection{The Approach of the Study}

The approach to the study belongs to the young tradition of evidence-based research or design-oriented research. This method, with its origins in medicine (Oshana, 2006, p.2) seeks to capture contextual complexity through empirical evidence, learn from practitioner experience about what works and propose practical ways forward for decision-makers (Gunn, 2004, p.3). Evidence-based research can be defined as the process of critically identifying approaches that have the strongest basis of empirical support for attaining desired outcomes (Oshana, 2006, p.1; Paynter, 2009, p.1, Fitzallen and Brown, 2007, p.2).

I have chosen this approach because of the nature of the literature on the subject that I am studying, and the importance of finding ways to identify the approaches that have the best chance of success in developing countries, given their institutional constraints. Paynter (2009) points out the dangers of relying solely on the academic authority of proponents when seeking solutions to practical problems, without grounding propositions on the actual evidence of their efficacy. He gives the example of the widespread use of lobotomy in the 1940s due to its enthusiastic promotion by prominent psychiatrist Walter Freeman. Lobotomy has since been proved to be a dangerous and ineffective procedure (Paynter, 2009) and there have been calls for the Nobel Prize awarded in 1949 to Egas Moniz, the founder of lobotomy, to be withdrawn on the basis that the method that won him the prize has subsequently been proven to be a fraud (Sutherland, 2004).

The literature on atypical performance in dysfunctional environments, though limited, consists of a plethora of inconsistent propositions, hypotheses and theories, many of which are equally applicable in good 
governance environments. This means that academics in this field are often unable to answer the simple question: "So, what do you recommend?"

As Siegel (2006, p.6) asks:

[...] what would be the point [...] if the results of all research were either worthless or equally legitimate? In these circumstances there would be no point in conducting research, because any result would either be worthless or stand on an equal epistemological footing with any alternative method.

The particular phenomenon that I am studying (atypical performance) in the environments in which I am studying it (dysfunctional environments) means that a classic approach to research is likely to have limited real value and validity. A more useful approach, with a greater likelihood of validity, would be to identify, explore, confirm and advance theoretical concepts based on empirical evidence and practitioner knowledge. The relevance of any theoretical concepts advanced would be based on its ability to work in real world contexts (Gunn, 2004, p.16).

Evidence-based research often consists of five iterative steps (Gray, 2004):

1. Formulate the question

2. Search for answers

3. Appraise the evidence

4. Apply the results

5. Assess the outcome and confirm results with practitioners

Using this method successfully requires both a deep immersion in the evidence (coupled with practitioner experience of what works), and an iterative approach to theory building that views theory from multiple perspectives. This process consists of constantly abstracting, generalising, relating, selecting, explaining, synthesising and idealising emerging data and knowledge all through the study (Weick, 1995). I have done these progressively as I struggle with empirical evidence, hypotheses and propositions throughout this study (Weick, 1989), and have progressively 
deepened my understanding of what works and why with each subsequent chapter.

To ensure that I capture relevant observations I have kept a Theoretical Sensitivity Diary (Strauss and Corbin, 1990) to record empirical insights from practitioners and their compatibility with theoretical propositions in the literature. I have, therefore, not adopted a classic Grounded Theory approach, as I have started my search for answers not with a blank sheet of paper but from my own practical experience, the insight of other practitioners, and known propositions, hypotheses and theories from the literature. The research approach that I have used is more fully set out in Chapter 3.

This study relies on qualitative research methods as they are more suited to explaining and understanding human phenomenon than focusing on numbers (Miles and Huberman, 1994, p. 10). I have used a comparative case study approach since I am examining a contemporary phenomenon in its real life context, especially as the boundaries between the phenomenon (atypical public sector performance) and the context (dysfunctional environments) are not clearly evident (Yin, 2009, p. 18). From the case studies, I will seek to build theory (Eisenhardt, 1989) that explains this phenomenon in a practical context.

Although the study is an empirical one, I will seek to apply a Realist epistemology in the interpretation of the findings. A lot of social science research is based on trying to achieve regularity through statistical models and random surveys.

Realism replaces the regularity model with one in which objects and social relations have causal powers which may or may not produce regularities, and which can be explained independently of them. In view of this, less weight is put on quantitative methods for discovering and assessing regularities and more on methods of establishing the qualitative nature of social objects and relations on which causal mechanisms depend (Sayer, 2010, p.2).

The phenomenon of strong organisations in weak states is "something whose occurrence is idiosyncratic and therefore perhaps an exception to the 
normal causal patterns sketched by research" (Leonard, 2008, p. 11). Leonard warns against reading the conclusions from the various hypotheses deterministically. There is a need to look for the deeper meaning of the conclusions thrown up by empirics. The empirics will throw up the observable conclusions based on experience. Realism will help us to understand why the complex factors at play work in the way that they do.

The organisations chosen for the study were chosen for their political and/ or economic importance, their perceived and actual effectiveness or ineffectiveness, and the possibility of wider replication that they offer. The study focuses on pairs of similar organisations in three fields (Anticorruption, Regulatory Quality and Revenue Administration). Choosing pairs of organisations in each field will make it possible to continually evaluate the validity of emerging findings in a comparative way throughout the study. As an example, if function is the key for organisational performance, why do two organisations that carry out broadly similar functions perform differently? Also, if it is found that performance has improved across various functions principally as result of, say, demand from the media, then it would make the finding that demand is the key ingredient more robust.

The selection of the case studies is limited to federal organisations and does not include sub-national organisations. All the cases selected therefore operate the same public service rules, have the same budgetary provision arrangements, are headquartered in the same physical environment, and are bound by similar regulations in recruiting, promoting and rewarding staff. This will make it possible to assess the internal factors such as leadership and management within the same setting. The same underlying external factors should also apply to all six case studies and the chosen approach will make it possible to assess the impact of political and institutional conditions on organisational performance in a comparative way.

The study is focused on only one country as it is necessary to understand the phenomenon of atypical performance within the same institutional context. By focusing on organisations within the same country, the study will consider various hypotheses and propositions within a defined political and institutional context. 
However, because the issues considered in this research are of relevance beyond the country in which it is set, and the country in which the study is set is symptomatic of other developing countries, the findings of the study will have wider relevance beyond one country. The research should therefore make a useful contribution to the literature on the subject.

\subsection{Significance of This Study}

This research aims to find out how and why some organisations in weak governance environments manage to escape the norm of poor performance. This phenomenon, often overlooked by most authors, is potentially very important for development policy-making and development assistance. A recent review of the last twenty years of empirical research grounded in institutional theory found that $95 \%$ of the studies focused on developed countries, with only $5 \%$ trying to test the institutional theory on developing countries (Hafsi and Farashahi, 2005).

To address this paucity in research, there is now a growing body of researchers studying this phenomenon. However, current insights tend to be tautological, static in time and oblivious of the political, historical and sociological context in which atypical performance is occurring (Tendler, 1997, pp. 1-8; Leonard, 2008, p.8). As Grindle (1997, p.483) admits about her own study, the purpose of most literature on the subject is often to raise potentially interesting hypotheses but not to assess them fully. Therefore, beyond confirming what is now increasingly common knowledge, that even in the worst institutional environments some organisations are doing well, they simply describe the key organisational conditions that they have found in the particular organisations studied and propose hypotheses on that basis. These will usually include good leadership, clear targets and a strong performance management culture (Grindle, 1997; Tendler, 1997; Leonard, 2008). Quite often, there are little or no explanations about how and why these organisations came about in the first place (Leonard, 2008, p.3) and what equipped them to be able to secure the good leader, set the clear targets or implement the strong performance management practices without opposition from the status quo. There are also often no proposals 
about how to build a critical mass of these organisations and each atypical organisation is treated almost as a happy accident.

Generally, a better understanding of this phenomenon could yield some good practices and useful incentives for other weak governance states that seek to achieve improved public sector performance. Building this understanding will involve looking to see whether there are other underlying variables that may not be immediately apparent. For instance, did political, historical, sociological, environmental, international and organisational factors converge sufficiently strongly at some point in time to give the organisation the space it needs to perform?

All the causal factors that have been listed by previous studies are potentially valid, and are perhaps equally applicable in strong states as they are in weak ones. Specifically, sequencing the main internal and external factors in order of occurrence or convergence, based on empirical evidence, will help to focus the efforts of reformers. This will avoid the dissipation of efforts that will occur if the more than five dozen ideas that have been hypothesised are to be pursued concurrently in an attempt to reform an organisation. This sharper focus could lead to performance gains across the board if this approach can be used to create an emerging critical mass of well-performing organisations.

The advantages conferred by the way that the study is set up also necessarily results in a number of limitations. While there is no fixed minimum number of cases that should be undertaken in case study research, six cases is usually the minimum that one would expect in this sort of study. Undertaking the study on just six organisations means that any generalisations are only safely made at the level of theory. Although basing all six cases in one country meant that they could be studied within the same institutional environment, the findings of the study would have been even more persuasive if we had looked at cases in other countries. 


\subsection{Outline of the Dissertation}

This dissertation has nine chapters, including this introductory chapter. Chapter 2 reviews the literature on the subject by discussing the theoretical concepts of state, institutions and public organisation. It attempts a marriage between theory and experience which provides a good basis for the empirical evaluations in the study. The meaning of the state and its role is explored and the effect of globalisation on the power of the state is discussed. The state in the African context provides the immediate backdrop for the study, before leading into the discussion on how public sector organisations help states to fulfil their roles. The literature on the subject suggests that weak states are characterised by weak institutions which, in turn, breed weak organisations. However, some organisations are overcoming this fatalistic view by managing to deliver good public services, against all odds, and the chapter therefore sets out the limitations of the current literature. The concept of demanding good public service delivery is differentiated from that of demand-side accountability - the former including the desire, ability, power, and willingness to get better public service delivery, while the latter focuses on desire without necessarily including the power and ability to bring about the desired objective. I start to explore the concept of demand in more detail, including the varying abilities of various actors to resource demand. I also propose an initial framework for assessing the availability of demand. The chapter concludes by setting out the conceptual framework that will guide the study.

Chapter 3 outlines the research design and methodological approach that is used in the study. It sets out the logic linking the data to the developing theory of demand and how I intend to interpret the findings (Yin, 2009, p. 27). It also explains the rationale for choosing qualitative research methods based on case studies, and the justification for the areas of focus chosen. Finally, the chapter describes the case selection methodology adopted, the data collection plan and the data analysis protocols.

Chapters 4 to 6 are the three case studies on which the empirical aspect of this research is based. Chapter 4 is the case study on anti-corruption, which focuses on the Economic and Financial Crimes Commission and the 
Independent Corrupt Practices Commission. Chapter 5 is the case study on regulatory quality, focusing on the National Agency for Food and Drug Administration and Control and the Standards Organisation of Nigeria. Chapter 6 is the case study on revenue administration, focusing on the Federal Inland Revenue Service and the Nigeria Customs Service. Within each case study, there is a brief background and history section for the focal organisations. I also review the literature pertinent to each case and assess the key hypotheses from the literature and my own developing theoretical propositions. Each case study concludes with an analysis of empirical data and conclusions and findings.

Chapter 7 is a cross-case analysis of the three case studies against the various hypotheses and propositions. It harmonises the findings from the empirical sections and collectively evaluates them against various hypotheses and theories. Additionally, it attempts the creation of a hierarchy of key factors that bring about atypical performance in dysfunctional environments.

Chapter 8 advances the theory of demand more fully and makes the case for reform efforts to be concentrated in three main areas.

Chapter 9 concludes the study, sets out its limitations and suggests areas for future research.

\subsection{Conclusions}

In summary, this chapter provided the setting in which the research is being conducted. It describes the difficult institutional environment in which public organisations in many developing countries have to operate, and begins to explain why, even in the most difficult environments, some public organisations still perform creditably well. The research problem, dependent and independent variables, initial hypotheses and general approach to the study are briefly discussed. The outline of the dissertation is set out and an argument is made for the contribution that the study will make to the body of knowledge on the phenomenon of strong organisations in weak states. 
Various theories, hypotheses and concepts have been advanced in the literature to explain how states, institutions and public organisations work. Within these is a growing body of literature on 'pockets of effectiveness' in dysfunctional environments and how they come to exist and survive. A review of the literature on these theories, hypotheses and concepts is the subject of the next chapter. 


\section{Chapter 2 Theoretical Concepts: In the Guise of a Miracle}

Theory without experience is empty but experience without theory is blind (Kant, quoted in Goreham, 2009, p.73).

This chapter reviews the current literature on public sector performance in weak states. It explores the meaning and role of the state and the various institutional theories that underpin key propositions in the literature. It argues that a lot of the widely-quoted institutional theories are fatalistic in outlook and that, regardless of difficult operating environments, a number of public sector organisations are performing well. Although there is a growing body of literature on this phenomenon, the current literature is still limited in significant ways. This chapter sets out the key issues in the literature and proposes a Conceptual Framework to guide the analysis of the findings and develop my understanding of the key concepts and theories.

\section{$2.1 \quad$ The State}

The term 'state' is used to refer to a wide range of things. Thomas Hobbes in his book, Leviathan, alludes to a common power that everyone respects and defers to. Without such a power, people exist in a "state of nature" and each person will do what is necessary to preserve their own life. He describes this state as "solitary, poor, nasty, brutish and short" (Hobbes, 2008, p. 84). Hobbes takes forward this argument and makes a case for civil government formed by the agreement of society (Hobbes, 2008, p. 111). Although John Locke differs from Hobbes about the state of nature, saying instead that it is a state of perfect freedom, equality and reason rather than one of base instincts, he agrees with Hobbes on the need for civil authority and an organised government, so long as that government draws its legitimacy from the consent of the people (Locke, 1988, p. 268). 
The 1997 World Development Report: The State in a Changing World defines the state as "a set of institutions that possess the means of legitimate coercion, exercised over a defined territory and its population, referred to as society". It adds that the state monopolises rulemaking within its territorial boundaries using an organised government (World Bank, 1997, p. 20). In his book, Politics (Heywood, 2002, p. 91), Andrew Heywood discusses the meaning of the term "State" drawing on the writings of Georg Hegel, Karl Marx and Max Webber. He defines a state as a political association that establishes sovereign jurisdiction within defined territorial borders, and exercises authority through a set of permanent institutions. It encompasses all public bodies (including government) and exercises impersonal authority on the basis that it represents the permanent interests of society.

A synthesis of the various definitions of State suggests four key characteristics: a monopoly over the means of legitimate violence; a defined territory; impersonality in the exercise of authority; and an identified population/ society. It is accepted that this synthesis generalises the nature of the state, as some societies are sometimes recognised as states, even though they do not currently have a settled territory (like Palestine) or an identified population (like the Vatican).

\subsection{The Role of the State}

The debate about what the role of the state should be has raged for centuries, and is still not settled. Issues in the debate have included the extent to which the state should intervene in civil life, the balance between state intervention and personal liberties, and the responsibilities that the state should fulfil on behalf of society.

There are a number of rival theories about what the role of the state should be. Andrew Heywood (2002, p. 99) summarises the main competing theories thus:

- Minimalist states seek not to interfere in peoples' lives and merely lay down the conditions for orderly existence. 
- Developmental states attempt to proactively intervene to promote growth and economic development.

- Social-democratic states strive to correct imbalances created by market forces.

- Collectivised states attempt to exert control over the entirety of economic life; and

- Totalitarian states take that control beyond the control of economic life and attempt to control all facets of human existence.

In many developed economies, the argument has often been between the proponents of a social democratic state (often called "the old left") and those that advocate a minimalist state ("the old right"). Both camps have gradually moved towards the centre and are now described as "new left" or "new right", but, although the lines between both camps are now often blurred, the basic instincts remain the same. In his important book, The Third Way, Anthony Giddens describes these basic instincts thus: "The neoliberals want to shrink the state; the social democrats, historically, have been keen to expand it." (Giddens, 2009, p. 70)

The collapse of the Soviet Union damaged the "old left", perhaps fatally. Although social democrats could point to successful interventions like the welfare state, the collapse of the Soviet Union was equated by many to the collapse of the social democratic ideology, and an ideological victory for the minimalists and the advocates of "market forces". It was not until the mid1990s that "the left" started to articulate a revised ideology. This new ideology is best set out in Giddens' book The Third Way. His central argument is that the focus should go beyond the arguments of too little state (by "those who say that government is the answer") or too much state (by "those who say government is the enemy") and instead be on the need for government to actively adjust to contemporary challenges like globalisation and climate change. He sets out ideas about how democracies can gain the benefits that flow from market forces while creating a society that is caring, just and inclusive (Giddens, 2009, pp. 64-70).

The Prime Ministerial Debates on television in the run up to the 2010 United Kingdom elections show that the gulf between the opinions of the left and the right on the role of the state is no longer as wide as it was two decades ago. Both the left and the right have now moved towards the centre. In my 
view, the 1997 World Development Report settles the argument when it says:

State-dominated development has failed, but so will stateless development. Development without an effective state is impossible." (World Bank, 1997, p. 34)

\subsection{Globalisation and the State}

In what has been called "the argument of our time", the effect of globalisation on the state has provoked sharp differences of opinion among political scientists. In Globalization: the Argument of Our Time (Held and Hirst, 2002, p. 104), David Held and Paul Hirst, two of the best-known authorities on the subject, debate the effect of globalisation on state power and sovereignty. Held defines globalisation as the increasing extent, intensity and impact of worldwide interconnectedness, while Hirst understands it to mean increasing flows of trade and investments between parts of the world and between countries. One sees it as a new phenomenon; the other sees it as a continuation of centuries-old human interactions.

The question for us is the extent to which globalisation has diminished the power and role of the state, if at all. Held, Giddens (2002, p. 9) and others argue that the power and role of the nation state has diminished as a result of globalisation. On the other hand, Weiss (2000, pp. 1-15) and Clarke (2004, pp. 27-48) are of the opinion that the effects of globalisation on state power are often overstated.

In my view, while globalisation has led to increased, and perhaps unprecedented, interconnectivity, the sovereign state still has a powerful and important role in shaping the lives of its citizens, delivering or ensuring the delivery of public goods and providing the enabling environment for globalisation itself to thrive. As Giddens himself later admits, "Nations retain, and will do for the foreseeable future, considerable governmental, economic and cultural power, over their citizens and in the external arena" (Giddens, 2009, p.32). He goes on to list eleven things that Government 
exists to do, including providing a diversity of public goods, and says that "the list is so formidable that to suppose that the state and government have become irrelevant makes no sense" (Giddens, 2009, p. 48). I agree with him up to that point. I don't fully agree when he goes on to say that nations will only be able to wield such powers in active collaboration with one another and with transnational groups and associations. Many nations (China is an example) wield their in-country powers in absolute terms. It is true that they trade with other nations and belong to international bodies such as the United Nations. It is also true that global communications lead to an exchange of cultures and ideas. However, it would not be correct to say that the state wields its power over its citizens only in active collaboration with any other nation, group or association. Nobody - citizens, other governments or transnational groups - should be in any doubt about the primacy of the nation state or its awesome pervasive power.

The global economic crisis of 2008 to 2010 provides a fresh imperative to look again at the role of the state. It has provided an added rationale for states to intervene in the market in the interest of its citizens by temporarily nationalising certain financial organisations and injecting tax payers' funds into others. Unless it can be shown that such situations as the current crisis can be effectively addressed without state action, there is a need to add state intervention in the economy onto the list of the proper roles of the state (Williamson, 2009).

\subsection{The African State}

Many writers blame colonialism for Africa's underdevelopment. Writing on the failure and collapse of the African state, John Akude starts his article by saying that:

Africa was forced into modern state making through the process of imperialism and colonialism, processes that marginally integrated African states into the international political economy, primarily in the interest of the colonising states as victuallers of raw materials for industrial 
production and markets for the same [...] This had debilitating consequences for economic development and state institutional capacity (Akude, 2007, p.1).

In his important book, Revolutionary Pressures in Africa, Claude Ake, like many other post colonial African academics, relying on books such as Walter Rodney's How Europe Underdeveloped Africa, (Rodney, 2009), does not even bother to make the case for the argument that colonialism was responsible for Africa's underdevelopment. Instead, he says: "I will be taking for granted the causal relation of neo-colonial dependence to the underdevelopment of Africa" (Ake, 1978, p. 33).

I believe that although colonialism had adverse effects on Africa's development, fifty years of independence is sufficient to reverse many of its negative effects. There is a need to "live down the past" (Collier, 1996, p.325) and move on like many other post-colonial countries have done. As Wangari Maathai said:

Fifty years down the road, we ought to be doing things differently. You cannot blame corruption in Africa on colonialism. You cannot blame colonialism for the excessive luxurious lifestyles that African leaders assume. You cannot blame it for the mismanagement of the economy or the fact that we have not invested adequately in education. Yes, colonialism was terrible, but we ought to be moving away from that by now (Maathai, 2011).

The struggle against colonialism lent itself very well to leftist ideology. The desire to expel the colonialists through violent revolution (Fanon, 1963; Nkrumah, 1964; Cabral, 1974), attain independence, and create a fairer and more just society largely drew inspiration from the Soviet socialist experiment of the time. The overriding ambition in many African states was therefore the overthrow of the colonial bourgeois by the African proletariat and the need to do everything possible to ensure that the new African leadership that emerges after the end of colonialism does not simply step into the shoes of the departing colonial bourgeois (Fanon, 1963, p. 133). 
This socialist ideological backdrop meant that most developing countries in Africa emerged out of colonisation with a strong belief in state-dominated economic development. By the 1960s, states had become involved in virtually all aspects of economic life. There were state owned farms, hotels, radio stations, carpet factories, transport companies, airlines and textile factories. This "overdevelopedness" went far beyond what was necessary for the orderly function of post-colonial society (Alavi, 1982, Gana, 1985). By the 1980s, these state-owned enterprises were mostly moribund and were principally conduit pipes for embezzling public funds and rewarding political cronies. Because state-owned enterprises fulfilled these perverse roles, the collapse of the Soviet Union did not result in as radical and immediate a shift in thinking about the role of the state in Africa as it did in Eastern Europe.

However, many African countries have moved from one theory of state to another during their existence, along the entire spectrum of "too much state" to "too little state". These shifts in ideology about the role of the state in Africa have not been linear and sequential.

Immediately after attaining independence, many African countries experimented with the social-democratic and collectivised approaches to statehood. Ghana's Kwame Nkrumah proposed an African socialist ideology known as "Consciencism" which was essentially an attempt to adapt Marxist ideology to the African context by situating it within African history, traditions and colonial legacy. Perhaps the most notable example of the socialist experiment in Africa was in Tanzania where Julius Nyerere introduced the concept of an indigenous form of socialism called Ujamaa, a KiSwahili word which he translated to mean 'familyhood'. Ujamaa sought to build on the pre-colonial heritage of African communal living by encouraging people, and later forcing them, to live in self-sufficient rural villages. On the whole, it was a catastrophic failure (Meredith, 2006, pp. 249259).

Two decades after independence, many African states were in serious economic trouble and were forced to seek the help of international finance organisations to keep from going bankrupt. In what became known as the "Washington Consensus", international financial organisations such as the World Bank and the International Monetary Fund steered states towards a 
minimalist theory of statehood where market forces dominate and the role of the state is simply that of an arbiter (Amuwo, 2009, pp. 37-61; Tendler, 1997, p. 4). This "hollowing out the state" was the dominant thinking in the West in the 1980s (Rhodes, 1996, p. 661) and in turn dominated the thinking of the major international financial bodies.

By the early 1990s therefore, most African countries had abandoned the idea of the state as the "engine of growth" and embraced market liberalisation. This sought to rebalance the roles of the state and that of the market, with the state taking a smaller role. Reducing the role of the state in this way encouraged many African countries to embrace New Public Management, key features of which are corporatisation, commercialisation, privatisation or outright sale of government delivery agents (Adamolekun, 2007, p. 9).

However, by the end of the 1990s, many African states felt that the Minimalist approach had not served them well and developed a renewed interest in the Development State approach (Mkandawire, 1998). Botswana is generally seen as a successful development state. Per capita income in Botswana, unlike in most other African countries, grew by $7.7 \%$ annually between 1965 and 1998. Apart from the key ingredients of law and order, prudent management of resources and an effective bureaucracy, Botswana intervened massively in its economy and its public sector is much larger than in many African states (Rodrik, 2003; Tendler, 1997, p. 4). Similarly, the World Bank and other major international lenders had, by then, come round to the idea of the proactive, intervening, state (World Bank, 1989).

Many African states have suffered military coups since independence and the ideology of the military regimes could be viewed as Totalitarian. Some other countries, such as Sudan and Somalia, have effectively failed as states and it is impertinent to talk about the role of the state in such instances.

In summary, there is usually a lack of clarity about the particular theory of state that African countries subscribe to. In many cases, the vestiges of postcolonial socialist ideology are mixed with totalitarian military ideology, to which is added attempts to realign the role of the state in the face of market forces and globalisation. The resulting concoction leads to confused state action. Some national constitutions set out a state-led economy but the governments in power are forced by international finance organisations, or 
motivated by corruption, to sell off state-owned companies. These companies, worthless as going concerns, are usually sold to government cronies for a fraction of their true value considering the fact that they would usually own extensive landed property and other assets at home and abroad. While states like Botswana and South Africa are making conscious efforts to create Developmental states, the position (in practice) in the rest of the continent is less clear. Nevertheless, the current rhetoric in the vision documents and/or national development strategies of many African countries continues to be that of a small state where the market has primacy (Adamolekun, 2007, p. 9). However, their observable actions often run counter to that rhetoric.

\subsection{Public Sector Organisations and the Role of the State}

Regardless of the theory of state that the state subscribes to, any state has five main roles with regards to the provision of public goods. First, as a direct provider of services. Second, as a commissioner of services, where the state specifies the required outcome but pays a supplier to provide the service. Third, as a regulator of services, ensuring that standards are complied with. Fourth, as a provider of information, so that citizens can make informed choices. Fifth, as a legislator to set down clear rules of behaviour (Cabinet Office, UK, 2007). A major vehicle of the state for the delivery of services is its public sector organisations, although governments can sometimes use other vehicles such as non-governmental organisations and faith groups.

Public sector organisations can simply be defined as publicly owned organisations that receive public funds from government budget allocations (Walmsley and Zald, 1973). They include the civil service, agencies and parastatals, the wider public service (such as the military) and local authorities.

In many developing countries, public service organisations perform poorly by all standards. In many cases, they do not deliver any services at all to the 
public and the overriding concern of many public servants can appear to be only for their own welfare. Incentives to perform well are often perverse and many officials develop finely-honed ways of obstructing the public's business and extracting rents and tolls for doing the job they are already paid by the public to do (Grindle, 1997). Performance Management in any sense of the word is virtually non-existent, and what exists is manipulated to ensure that it is virtually impossible to assess performance and seek improvement.

The environment for the delivery of public services is difficult in many developing countries. Poverty and a history of military coups and repressive regimes have silenced opposition and driven skilled people into exile (Hilderbrand and Grindle, 1994). State and national resources are ravaged, human development is de-emphasised, and there is little economic development and a heavy dependence on foreign aid. Jinadu (2009, p. 4) lists some of the structural problems facing African countries to include:

- Weak management capacity in the public services

- Low investment by the public and private sectors in research and development

- Prevalence of endemic and preventable diseases like malaria and HIV/AIDS

- Kleptocratic behaviour by political leaders

- Huge external debt

- Monoculture economies

- High levels of illiteracy

- Fragile and deteriorating infrastructures in education, health, transportation and water resources

- Brain drain, resulting in the loss of critical human resources in key areas

- Environmental degradation

Collectively, these constrain the capacity of public organisations to perform well (Hilderbrand and Grindle, 1994). Public-employment is used as patronage and many political supporters are on the payroll simply to collect monthly salaries and do not even bother to turn up to the office except on payday. Money is extracted from the heads of public organisations, particularly to fund election expenses, and the chief executives are ordered, 
or encouraged, to award contracts to party members and make hefty advance payments, often for non-existent projects. Selection or promotion based on merit is resisted and, in many developing countries, civil services have emerged as powerful interest groups, typically protected by the constitution and by tenure provisions which make it easy for them to resist reforms designed to improve their performance (Shepherd, 2003).

In properly functioning political systems, the legitimacy of the government is drawn from its ability to improve the life of its citizens through the provision of public-sector-only services, such as tax administration, policing or child protection; or the provision of services to a section of society, such as the unemployed, who cannot afford to pay the market price for them, e.g., through the provision of social housing, state pensions or care for the elderly. Beyond public sector services, the government also seeks to provide the right sort of environment for the private sector to thrive. This may include the use of the private sector and other non-state actors to deliver public services. However, they are very much seen as agents of the government and the ultimate responsibility for the provision of those public services rests with the government. When governments go to the people to seek their mandate to govern, they ask to be judged on the records of their performance, if they are already in office, or on the strength of their propositions if they are in opposition. It is based on a relationship of responsibility and accountability that is mutually reinforcing.

Figure 1 represents the four dimensions of the ideal relationship between the politicians, public servants in public sector organisations and citizens:

i. Citizens freely choose their government and give them a mandate to govern, accompanied by demands

ii. Politicians devise policies to respond to those demands, pass them on to public servants for implementation and hold the public servants accountable for delivery

iii. Public servants translate those policies into goods and services for citizens and deliver those goods and services fairly and impartially to all citizens

iv. The relationships between citizens, politicians and public servants are complex and could flow in different directions. For instance, citizens also make demands directly of public 
servants and politicians make demands on citizens (e.g., the demand for taxes).

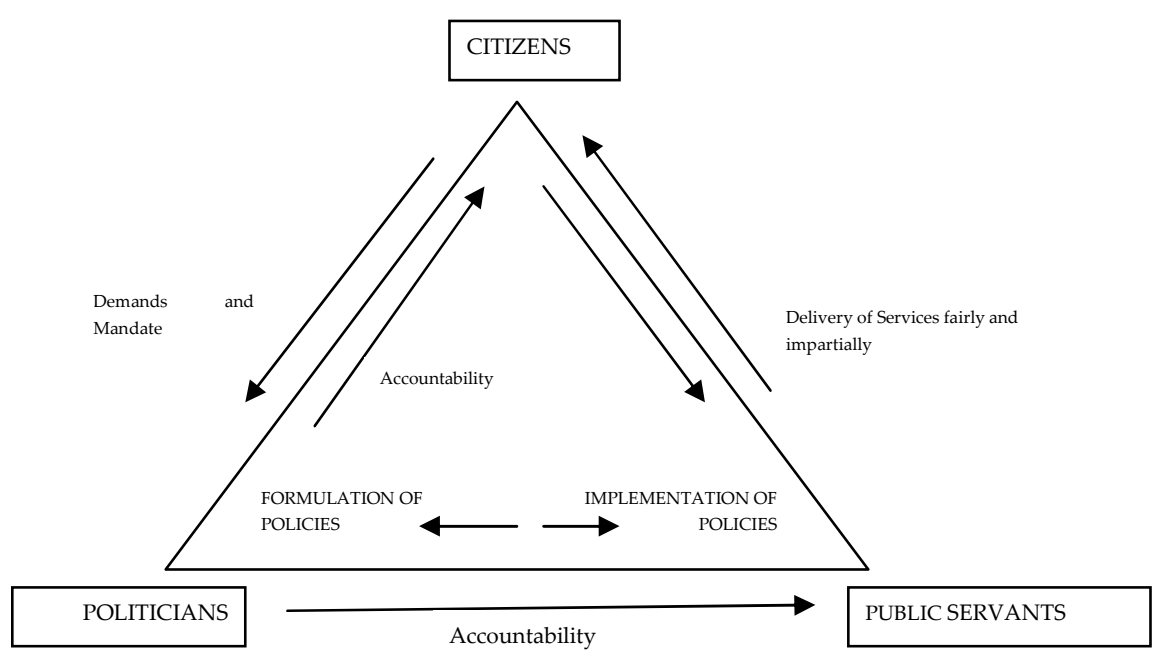

Figure 1: Relationship of Citizens, Politicians and Public Servants ${ }^{1}$

Politicians promise to deliver better health care, safer streets, national security, economic prosperity and lower taxes and ask to be judged on their record of delivering on their promises. However, it is difficult to measure performance against these promises in any specific way and there are difficulties with attribution (Talbot, 2007: p. 491). Nevertheless, what is described above and in Figure 1 is an ideal situation that does not exist in many African countries.

${ }^{1}$ Adapted from Adamolekun (2007) 


\subsection{Institutions and Public Sector Organisations}

In the literature, the terms "Institutions" and "Organisations" are sometimes used interchangeably. In this research, I will use the term "Institutions" to refer to the way that things are done in a society, and "Organisations" to refer to groups of people (such as Ministries and agencies) intentionally organised to achieve set goals (McNamara, 1999).

Different authors use different definitions of institutions. The most commonly accepted definition is that institutions are the rules of the game in a society, together with their enforcement arrangements. They are the humanly devised constraints that shape human interaction. They structure incentives in human exchange and shape the way that societies evolve over time. For institutions to survive, these rules of the game (formal and informal) need to be shared and accepted by members of society, enforced for compliance, and passed on to new members of society through socialisation and education (North, 1990).

The idea that the external environment has an influence on organisational performance is widespread in the generic management and public management literature (Boyne and Meier, 2009). Political, economic, legal and social contexts directly affect the performance of organisations and indirectly affect organisational structures, processes, and managerial behaviour (Lynn, et al., 2000). In other words, "Institutions Rule" and weak institutions are likely to breed weak organisations (Rodrik, et al, 2004; Holdt, 2009).

Three main schools of thought currently dominate the literature on institutional theory: Rational Choice Institutionalism, Historical Institutionalism and Sociological Institutionalism (Thelen, 1999, p. 369). Each school of thought represents a mountainous body of literature "characterised by tremendous internal diversity" (Thelen, 1999, p.370). 


\section{Rational Choice Institutionalism}

This approach to institutional theory, with its origin in economics, is based on the premise that actors make rational preferences based on the need to reduce transaction costs. Transaction costs arise because of the bounded rationality and opportunism of transacting parties. In other words, institutions (rules of the game) will emerge to achieve an optimal match with a particular transaction (Williamson, 2000).

However, this theory cannot explain why different countries (or organisations) with similar technologies may use different institutions to govern apparently similar transactions; why inefficient institutions (and organisations) often tend to persist; or why less successful societies (or organisations) often fail to adopt the institutional structure of more successful ones (Kingston and Caballero, 2006). In many developing countries, competition has not weeded out inefficient institutions. Indeed, the elite in these countries (the groups with political power) choose policies to increase their income and to directly or indirectly transfer resources from the rest of society to themselves (Acemoglu, 2006).

\section{Historical Institutionalism}

Proponents of Historical Institutionalism attempt to construct sequences of events based on historical patterns. The "Path Dependency" theory (Skocpol, 1985; North, 1990) explains that societies, polities and economies evolve differently over time principally because of certain paths they have historically taken, the solutions that they have chosen, and how they have adapted to change over time. In essence, when societies, polities or economies consistently perform poorly, an examination of their history will provide the answers why (Ikenberry, 1994; Thelen, 1999).

In his seminal article on "Colonialism and the Two Publics", Peter Ekeh (1975) explains why public servants in Africa and other post-colonial societies tend to chose the path of poor performance. He argues that in the minds of post-colonials, there are two publics: 
- a "primordial public" (usually at his village or tribe level), which is moral, just and communal. To this public, the person will give his all, will not embezzle communal funds, will aim for optimal performance in all endeavours, will look out for the interests of others, and will strive for the common good; and

- a "civic public" (such as the civil service and the parliamentary and presidential systems of government) which was created and imposed by colonial masters, which is amoral, deserves no loyalty, dedication or taxes, and should instead be extracted from to feed the needs of the primordial public.

Ekeh's propositions represent perhaps the most persuasive answer to the age-old African conundrum: Why does the African public servant deliver communal projects to time, cost and quality specifications (and without corruption), but is incapable of delivering government projects and is constantly in need of capacity-building and gratification? This theory fits well with the Path Dependency theory about the importance of history, as it blames the poor performance of many developing countries almost entirely on colonialism.

Although persuasive, Ekeh's arguments are not infallible. For instance, his assertion (in 1975) that the only non-Western nations to have successfully modernised are those that have never been colonised no longer holds true, with examples such as South Korea and Malaysia.

However, his arguments will still resonate with many post-colonials who would still argue that those post-colonial countries that have modernised (including successful Asian economies) have managed to develop because they have overcome the "two publics" in their minds by integrating their primordial publics with their civic publics. And therefore that the essential theory of the two publics in the minds of many public servants still holds true in many developing societies that have failed to develop.

\section{Sociological Institutionalism}

Sociological institutionalism highlights the importance of endogenous values and norms. Actors react not only to the formal rules of their institutional environment but also through moral templates and normative 
orientations (Bell, 2002; DiMaggio and Powel, 1991; Hall and Taylor, 1996). Proponents of a Hierarchy of Rules approach (Libecap 1989, Ostrom 2005) argue that institutional change is an outcome of a political process and that changes in formal rules occur within a stable political context, with relatively predictable effects on behaviour.

Unfortunately, the political environment in many developing countries is far from stable and the Hierarchy approach cannot explain why some formal rules (like legislation and codes of conduct) are effective and others are not. It also does not capture the importance of Informal Rules (cultures and customs) which condition the way that things are done in many societies.

The "Equilibrium View" of institutions (Calvert 1995, Aoki 2001, Greif 2006) regards formal and informal rules as essential to achieving a shared belief about expected behaviour, necessary for institutions to thrive. It is therefore useful as a broad conceptual framework for understanding institutional change, particularly in developing countries where changes in formal rules (like a constitutional amendment, new legislation or public service rules) often fail to have the desired effect (Kingston and Caballero, 2006, p. 20).

One of the most contentious issues in management theory is the impact of culture on organisational performance. One school of thought argues that management techniques and programmes which have proven to be successful in developed countries should work in developing countries (Waal, 2007). Another diametrically opposed view argues equally strongly that the socio-cultural environment of developing countries have in-built features that are not conducive to good public sector performance and actually inhibit performance (Mendonca and Kanungo, 1996; Piercy, et al., 2004). Geert Hofstede (2001, p.4) goes even further to claim that people from different societies are "collectively mentally programmed" to behave in certain ways.

However, given such "collective mental programming" of societies, Hofstede's theories do not explain why organisations in the same society have differentiated performance; why many private sector organisations in developing countries outperform their public sector counterparts; or why two different countries with the same peoples (and therefore supposedly 
identical mental programming) will achieve different economic performance indices - examples are the Koreans of North and South Korea and the Germans of what used to be East and West Germany. I will argue in this study that, although Culture is an important consideration, it has very little effect on the ability of public organisations to achieve atypical performance in dysfunctional environments.

\subsection{Overcoming the Fatalism of Institutional Theories}

It is now common knowledge that even in the most difficult institutional environments, exceptional, well-functioning, government and governmentsupported agencies exist. Despite operating in an environment of weak state capacity and ineffective public sector organisation, these so-called "pockets of productivity" can be formed and continue to thrive in environments that are generally hostile for productivity and results. (Uphoff, et al., 1998; Leonard, 2008).

Leonard lists dozens of propositions offered by various commentators who have attempted to explain the phenomenon. Helpfully, he has grouped these into five "mega hypotheses". Although many of the propositions cannot be said to the hypotheses in the proper sense of the word, we will stick with Leonard's use of the word, for now, for purposes of discussing the propositions. Leonard's five "mega hypotheses" are:

- Mega-hypothesis 1: An organisation's 'productivity' is largely determined by how it does its tasks - i.e., by management and leadership - not primarily by its function or its political context (Leonard, 1991; Grindle, 1997; Uphoff, et al., 1998). Within this hypothesis is the Goal Setting Theory of Organisational Change. The underlying premise of Goal Setting Theory is that conscious goals affect what is achieved. Goal setting theory asserts that people with specific and challenging goals perform better than those with vague goals (Verbeeten, 2008, p. 431). Therefore it would suggest that public sector organisations that have clear, specific and challenging goals (like an anti-corruption commission) will perform 
better than those with vague, unspecific and non-challenging goals (like a Ministry of Women Affairs).

- Mega-hypothesis 2: Function is more important for productivity than either management or political economy. Thus function and the associated technology, not management initiative, produce organisational specificity of benefits and incentives; and function, not political economy, lead to organisational autonomy (Leonard, 1991; Bebbington and McCourt, 2007).

Within this general mega-hypothesis is the Agency Theory of Organisational Change, which deals with the aspect of benefits and incentives. The Agency Theory argues that individuals will shirk responsibility and exert no effort on a task unless it somehow contributes to their economic wellbeing. Incentives play a fundamental role in motivation and performance because there is an opportunity for individuals to increase their wealth (Verbeeten, 2008, p. 433). Therefore, in public sector organisations, government officials are presumed to be in pursuit of only budgetary expansion, politicians of votes, and interest groups of only their own ends.

The second strand of the Agency Theory is that contractual interactions between various parties will align the interests of principals (those wanting something to be done, such as politicians and funding agencies) and their agents (like government officials and organisations). The result of such behaviour is an over-sized state, policies designed simply to satisfy voter preferences, and an economy distorted in favour of selected interests (Gauld, 2007).

This theory encounters difficulties when applied to public sector organisations, since these agencies can have multiple principals (the executive, the legislature or professional organisations), conflicting tasks and objectives, and a lack of competition. In many public sector organisations, people (like nurses) are often motivated by non-financial considerations. Also, these theories do not appear to factor-in the roles of history and national cultures in the behaviours of individuals and organisations. 
- Mega-hypothesis 3: The process by which efforts to improve performance are undertaken frequently can determine the viability of those performance improvements (Grindle and Thomas, 1991; Heredia and Schneider, 2002). This hypothesis argues that implementation that is relatively simple enhances the survival chances of the improvements and that consolidation depends on the durability of the benefits generated in the initial reform attempt and the continued power of those initial winners.

This mega-hypothesis also includes propositions that reform is more likely when there is a crisis since the crisis will bring the issue to the attention of the top political leadership; and the initial reform effort is more likely to survive if visible benefits are achieved relatively quickly, and if the costs of the reforms are manageable.

In my view, these are perfectly sensible propositions, given the impatience for results in many developing countries, the ability of crises to force the hands of reluctant reformers and the need to sustain the interest of reform champions through what are commonly called "quick wins".

- Mega-hypothesis 4: Political institutions shape what is organisationally feasible and cannot be deduced automatically from interests and power (Evans, 1995; Kaufman, 2003). Essentially, 'productivity' is more likely if administrative leadership is depoliticised but responsive to political leadership. Reforms are also likely to be initiated and consolidated if they fit with the dominant organisational patterns in society and if the political and social beneficiaries of the reforms challenge the status quo.

It is unclear precisely what depoliticised administrative leadership that is responsive to political leadership means. Presumably, it means that the chief executive of the organisation should not overtly engage in party politics but should be sufficiently politically-savvy to protect themselves and the organisations they lead. Again, these appear sensible, given that overt politicisation will damage credibility, but insensitivity to political leadership will lead to alienation, starvation of funds and lack of political support. 
- Mega-hypothesis 5: The underlying political economy in which an organisation is placed ultimately will shape all the other causal factors and determine what organisational productivity is possible (Leonard 2006; Bebbington and McCourt, 2007). Essentially, 'productivity' is more likely if the beneficiaries of the reforms are organised by their interests, not by patronage networks, to demand for improvements. The mega-hypothesis also recognises that interest groups, rather than patronage ones, exist in society and that they desire the delivery of decent public goods, rather than just predation and taking advantage of others.

In addition to Leonard's inventory, a number of authors have identified other factors that could potentially lead to atypical performance. In a study on what makes particular African local governments successful, the factors found to be necessary but, in themselves, insufficient included well-defined responsibilities in a satisfactory legal framework, capacity to mobilise sufficient resources, supportive central government activities and appropriate management practices, including the development of productive internal and external relations and satisfactory responsiveness to constituents (Olowu, 1992). Owusu (2005) and Waal (2007 and 2008) similarly identified internal and external factors that differentiates performance. Owusu found that what differentiates good and bad performers in Ghana are pay and hiring criteria. The good performers pay higher wages and recruit their staff openly and transparently while the bad performers pay low wages and manipulate the recruitment process for patronage purposes.

A study on the reasons for successful rural development experiences in different parts of the developing world identified issues such as leadership, organisation and participation, management, planning and implementation capacity, technology and training, the use of information, utilisation of external assistance, and an ability to deal with government and politics as the reasons for success in the programmes studied (Uphoff, et al, 1998).

In Good to Great (Collins, 2001), a study of how certain private sector firms had transformed themselves from good companies to great companies highlighted factors such as leadership, getting the right staff, a strong belief in organisational goals, competence, a culture of discipline, the use of 
technology to accelerate improvements, and relentlessness. Although this book has a private sector focus, some of its propositions are nevertheless relevant for assessing determinants of success in public organisations.

In summary, institutions matter but the constraints that they create are not insurmountable. This phenomenon of strong organisations in weak states, by its very existence, questions the deterministic validity and efficacy of institutional theory. It shows that actors and organisations do not always make rational choices, are not always slaves to their histories and can depart from sociologically accepted norms to deliver decent outputs for citizens. Beyond these, issues of causation are not to be treated deterministically. Instead, in coming to a view about what works and why it does, it will be prudent to look at combinations of certain variables in preference to the combination of other variables (Booth, 2010).

\subsection{Demanding Better Public Service Delivery}

The concept of demand, as applied in this research, is to be distinguished from concepts of social accountability, such as advocating for good governance. While demand includes the crucial ingredient of power and ability to resource change, social accountability is an approach to enhancing government accountability and transparency and strengthening the channels through which citizens can hold governments accountable for the use of public funds and the exercise of authority (McNeil and Mumvuma, 2006; McNeil and Malena, 2010). Social accountability mechanisms often do not contain the power to bring about immediate change in the behaviour of the elite, particularly in developing countries with a history of repression and authoritarian rule.

As was earlier stated, demand in the context of this research is a desire for something backed by the ability and willingness to pay for it or bring it about. This definition admits of concepts of pressure, needs, interests and desires. These pressures, needs, interests and desires can emanate from individuals, organisations, groups or government. However, the key qualifying condition for pressures, needs, interests and desires to transcend to demand, is the power to bring about immediate change. 
The demand on a specific organisation for better organisational performance can come from a variety of sources. One of the most important sources is the government of the day. While it may appear contradictory, on the face of it, that government is both a reason for dysfunction and an incentive for improvement, an "activist central government" (Tendler, 1997, p. 15) has perhaps an unrivalled ability to bring about change. Alexandra Gillies (2007) offers a useful insight into possible reasons why the former President of Nigeria, Olusegun Obasanjo, may have embraced reforms. These overlapping reasons may include:

- Personal prestige: to cultivate an image as an international statesman and visionary leader;

- National prestige: to advance Nigeria's image as a major player on the international stage and secure a permanent Security Council seat;

- Material gains: to obtain debt relief and encourage foreign investment;

- Domestic legitimacy and respect: to distance himself from the elite group that brought him to power, so that he can assert his own independence; and

- International pressure and incentives.

Intra-elite conflict can also explain why the group of elites in government may suddenly take actions that benefit citizens to the detriment of the opposing elite group, e.g., a focus on anti-corruption. The reasons for atypical behaviour may not always be altruistic. Pranab Bardhan notes that:

Populist rhetoric has been a useful weapon in clipping the wings of an over-greedy bargaining partner in the dominant coalition; profuse tears of commiseration with the masses shed on the floor of the Parliament and elsewhere have drowned a rival's extravagant claims. If the industrialists at any time overstep in their bargaining, sure enough there will be an uproar in the Parliament about 'the anti-people conspiracy of the monopoly capitalists'; similar invectives against the 'kulaks' or, somewhat less frequently, against the 'parasitic intelligentsia' 
will also be aired on appropriate occasions. The competitive politics of democracy thus serves the purpose of keeping rival partners in the coalition on the defensive (Bardhan, 1984, p. 77).

Demand can also emanate from other sources, such as the private sector, donors, service users or citizens generally. The various pressure and interest groups have varying abilities to resource the desired change. In many developing countries, service users and citizens often have little or no voice and service providers, little or no accountability. It is reasonable to expect that the weight of any demand by donors will vary depending on how donor-dependent the country is. The more donor-dependent the country is, the greater the weight that donor-demand is likely to carry. In Nigeria, the subject of this research, donor aid accounts for less than $1 \%$ of Gross National Income (USAID, 2006, p.20) and the private sector is heavily dependent on government business. I will argue therefore that the overriding source of demand for atypical public sector performance in dysfunctional environments is Government. I have therefore ranked the hierarchy of demand in dysfunctional environments thus:

1. Activist government (Tendler, 1997, p. 15; Gillies, 2007; Akunyili, 2010; Adebanwi, 2010; Amundsen, 2010)

2. Activist organisational leadership (Akunyili, 2010; Adebanwi, 2010)

3. Private Sector (Heymans and Pycroft, 2005)

4. Donors and the international community (Gillies, 2007; Amundsen, 2010)

5. Media, pressure groups and professional bodies (Akunyili, 2010; Ribadu, 2010)

6. Service users and citizens (Tendler, 1997, p. 5; McNeil and Malena, 2010)

Quite often, the elite will not stand in the way of atypical performance where the functions of the organisation in question do not immediately appear to harm the interests of the elite (Ghosal and Proto, 2009). However, once the actions taken have moved beyond the rhetoric and have produced legislation, a new way of doing things (such as a computerised payroll system) or a certain level of expectation among citizens, it becomes more difficult to completely abandon the progress that has been made and revert 
to the status quo ante. Some organisations can therefore produce and sustain atypical performance once certain initiatives have reached a sufficient level of maturity (Tendler, 1997).

\subsection{Limitations of Current Literature}

The best elaboration I have found of the general state of the literature on strong performance in weak states is in Judith Tendler's book, Good Government in the Tropics (Tendler, 1997: pp. 1-8). Although the book was written in 1997, the issues that are identified within it have not changed very much. The focus of most development literature about developing countries is still on poor performance; recommendations about improving performance are almost always from industrialised countries, including some Asian economies; whole countries are still labelled as good or bad performers, with little attempt to identify what might be working well within a poor governance environment; and recommendations for improvement in developing countries often ignore the large body of literature about high-performing organisations in developing countries and the characteristics that they exhibit.

However, there is still a growing body of literature about so-called "pockets of productivity" in developing countries, with an impressive array of hypotheses. Leonard (2008) attempts to annotate the various hypotheses in terms of which ones may be applicable when initiating reforms, which ones may be important in consolidating reforms, and which ones are applicable in both circumstances. However, the hypotheses are not ranked in any order of importance, and there is no explanation of whether or not they are all required to bring about change or only a subset is sufficient. Frankly too, almost all the hypotheses are equally applicable in good governance environments and do not make a special case for organisations that achieve atypical performance in dysfunctional environments.

In the literature on atypical performance in weak governance environments, each author either describes a range of characteristics of the atypical organisations they have studied, or proposes multiple (and sometimes 
conflicting) hypotheses to explain the phenomenon. However, the existence of these atypical organisations provides hope in the face of the fatalistic nature of institutional theory. It shows that an organisation can overcome institutional constraints to deliver public goods for citizens, against all the odds.

\subsection{Conceptual Framework and Link to Research Design and Methodology}

My conceptual framework for this study flows from the working hypotheses set out in Chapter 1. Essentially, the process of achieving sustainable atypical performance starts with national and global pressure for change in a particular organisation or field of endeavour. Local pressure for change can come from various sources - atypical government behaviour, individuals (such as the leader of the organisation), private sector actors, donors, pressure groups and the media, and users and citizens generally. Pressure from globalisation and international political sources, such as pressure to take steps to address money laundering/ finance for terrorism following the events of " $9 / 11$ " in the United States, the control of narcotics (as in Afghanistan), Climate Change, Corruption Perception Index ratings, pro-democracy agitation, and human rights campaigns, all create an imperative for improvements in certain areas. Local pressure generated from within the country can exist independently of the sorts of international pressure described above or can coalesce with them. These pressures can lead to demand where they also contain the power to bring about immediate change, or can simply remain as pressures (not demand) where that power is lacking.

Where there is demand on an organisation, it is more likely to bring into play the favourable institutional and organisational conditions that will make sustainable good performance possible. There is, however, a need for institutional conditions to be favourable and organisational conditions effective for organisations to achieve atypical performance. Where institutional conditions are favourable but organisational conditions are 
ineffective, the organisation will perform typically and any atypical performance will be short-lived and unsustainable.

Where there is no demand, institutional conditions are likely to be unfavourable. Where this is the case, even if organisational conditions are effective, organisations will only perform typically and any atypical performance will be short-lived and unsustainable. Where there is no demand and unfavourable institutional conditions are coupled with ineffective organisational conditions, performance is likely to be typical or worse. The above propositions are figuratively depicted in Figure 2 (my own elaboration):

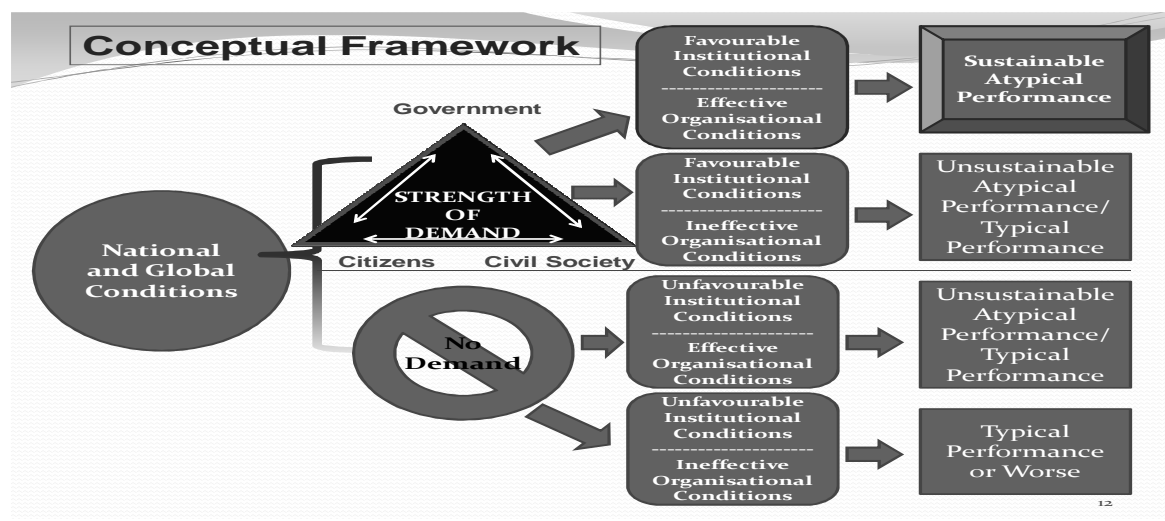

Figure 2: Conceptual Framework

Using the common meaning of the term 'demand', it is possible to argue that there is always a demand on organisations to perform well from citizens and organisations. However, where such agitations are not backed by the power to actually make it happen, they will not qualify to be termed demand, as I use it in this dissertation, as they are often insufficient in themselves to bring about change. The agitations will only become demand when they reach a certain level of imperativeness, and are backed by the power to effect the change. This is more likely if the government considers that there appears to be more to lose by maintaining the status quo than 
effecting change. I will continue to develop this concept of what I am currently referring to as demand throughout this dissertation.

\subsection{Conclusions}

The State is a set of institutions that monopolises the means of legitimate violence and exercises authority over an identified population within a defined territory in an impersonal way. Debates about what the proper role of the state should be have raged for centuries and continue unabated. While some people feel that government is the problem, others feel that government is the solution. Proponents of a "third way" try to find middle ground, and in recent times, both "the left" and "the right" have gravitated towards "the centre".

There have also been fierce arguments about the effect that globalisation has had on the power of the state. Some people argue that with globalisation nations have become mere 'fictions' (Giddens, 2002), while others say that globalisation is nothing new, that the world has always been interconnected, and that the nation state remains all powerful (Weiss, 2000). The current global economic crisis provides a potent imperative to revisit the role of the state. In recent times, states have intervened in the markets to protect the interest of citizens, sometimes by injecting public funds into private companies, or even going as far as nationalising them in some cases.

The position in Africa is not always very clear. Many African states emerged out of colonialism with a leaning towards socialist ideology. However, military interventions, social unrest and economic difficulties means that what obtains in many African countries is an incoherent mixture of ideologies about what the role of the state should be. Having said that, some countries, such as Botswana and South Africa, are striving towards the creation of a model that works for their own environments.

Public sector organisations are an important vehicle through which states fulfil their roles whether as direct providers, commissioners or supervisors of services. The effect of institutions on how organisations perform is generally recognised in the literature. The basic proposition is that weak 
institutions breed weak organisations. This would explain why many organisations in developing countries perform poorly, given the weak institutions that exist in those countries.

However, a number of organisations have managed to defeat this fatalist view and have been able to deliver decent public services. Rival theories exist to explain this phenomenon - some say it is because the organisations have clearer goals than others, and others say that it is the nature of their functions that makes it possible for them to surmount their difficult delivery environments. This phenomenon of strong organisations in weak states is the subject of this research.

The concept of demand, as used in this research is different from the demand for good governance through social accountability mechanisms. The current literature on atypical performance in difficult institutional environments is limited in that the large number of hypotheses developed to explain the phenomenon is not sequenced in time order or ranked in order of importance. Therefore it is difficult to ascertain what combination of factors can bring about sustainable atypical performance.

My approach to contributing to the current literature, by linking the theoretical concepts above to my empirical work, is set out in my Research Design and Methodology chapter, which immediately follows this current chapter. 


\title{
Chapter 3 Research Design and Methodology: Organised Scepticism
}

\begin{abstract}
All means are sacred which are called for by the inner need. All means are sinful which obscure that inner need (Kandinsky, 1997).
\end{abstract}

This chapter sets out the research design and methodology that I have adopted in this study. In this study, I have used the conceptual framework set out in Chapter 2 to explore 6 cases in Nigeria. Although basing research on a prior conceptual framework often provides security, focus and ease of analysis, conscious effort must be made to overcome the temptation to make the data fit the framework and to ignore unexpected findings that do not fit the framework (Simmons, 2010, p.33). Bearing this note of caution in mind, linking the research design and methodology to my conceptual framework will enable me to confirm, disprove, or refine my working hypothesis, that demand is the prior causal factor that catalyses atypical performance in weak governance environments.

\subsection{Research Approach}

This study uses the evidence-based research approach. Evidence-based research can be defined as the process of critically identifying approaches that have the strongest basis of empirical support for attaining desired outcomes (Oshana, 2006, p.1; Paynter, 2009, p.1, Fitzallen and Brown, p.2). I have chosen this approach because the literature on atypical performance in dysfunctional environments, though limited, consists of a plethora of inconsistent propositions, hypotheses and theories. I have therefore sought to find out what works in the practical context. 
This study is based on Qualitative research as it is more suited to explaining and understanding human phenomenon than focusing on numbers (Miles and Huberman, 1994; Blumberg, et al., 2008, p.192). Qualitative research emphasizes nuances, sequence and multiple perspectives (Stake, 1995, p.xii), which is the reason why the main methods that I am using are interviews, focus group discussions, observation and document analysis. I have used a comparative case study approach because investigating an issue in more than one context is often better than basing results on just one case (Blumberg, et al., 2008, p.376). Carrying out the study in a comparative way within the same fields will strengthen the robustness of my findings. As an example, if function is the key causal factor, why do two organisations that perform broadly similar functions perform differently? Also, if it is found that performance has improved across various functions principally as result of, say, demand from the media, then it would make the finding that demand is the key ingredient more robust.

Yin defines a case study as "an empirical enquiry that investigates a contemporary phenomenon in depth and within its real life context, especially when the boundaries between the phenomenon and context are not clearly evident" (Yin, 2009, p.18). I have chosen the case study approach because the boundaries between the phenomenon of atypical public sector performance and the context of dysfunctional environments are not clearly evident.

A case study is the study of the unique and unusual and its primary purpose is to explore that particularity and uniqueness (Simmons, 2010, p.3). It can be used to generate an in-depth understanding of a specific topic, programme, policy, organisation, institution or system (Simmons, 2010, p.21). The case study approach is explanatory and seeks to explain the causal links in human phenomena that are too complex for experiments and surveys (Yin, 2009, p.19). A common criticism of case studies is the notion that it cannot be generalised. This criticism is misconceived. It is possible to learn lessons from an in-depth enquiry of unique situations that may be universally generalised. However, like experiments, case studies can only be generalised to theoretical propositions and not to populations or universes (Yin, 2009, p.15; Simmons, 2010, p.20). 
This study focuses on pairs of similar organisations in Nigeria. I have chosen Nigeria for three main reasons. First, the country presents an interesting paradox of being a developing country, but which, by all known laws of political or social science, should have collapsed and disintegrated years ago (Dowden, 2009). In the context of this research, it could therefore be described as a somewhat atypical performer. Second, Nigeria is an important country in the developing world, with a population of 167 million people (Nigeria Population Commission, 2011) representing about $25 \%$ of all Africans. Therefore any insights gained from a study in that country should be useful for the rest of the developing world, particularly Africa. Third, I have been a participant-observer in the phenomenon of atypical organisations in Nigeria and elsewhere for nearly two decades, and have good access to the key actors. In case study research, the author is the main instrument in data gathering, interpretation and reporting (Simmons, 2010, p.4). This makes it inevitable that there will be some element of subjectivity, but every effort has been made to be controlled and disciplined and to minimise researcher bias. As an example, in designating an organisation as typical or atypical, I have relied on the actual performance achieved against stated objectives and targets, rather than just relying on subjective views and opinions.

The selection of the case studies is limited to federal organisations and does not include sub-national organisations. Focusing the study only on federal organisations means that all the cases selected operate the same public service rules, follow the same budgetary provision arrangements, are headquartered in the same physical environment, and are bound by similar regulations in recruiting, promoting and rewarding staff. This made it possible to evaluate the organisational and managerial hypotheses in Chapter 2 within the same setting. The same underlying political and institutional issues also apply to all the case studies and the chosen approach enabled me to evaluate those hypotheses that relate to political economy within the same context. The study is also limited to one country for the same reasons. This approach of unearthing and explaining promising developments within one country that performs poorly on the average, and highlighting good performance by some government agencies as distinct from others in the same country, is a useful addition to the literature (Tendler, 1997, p.3). 
My primary unit of analysis is organisations. Blumberg (2008, p.224) describes the unit of analysis as the level at which the research is performed. The pairs of organisation are then comparatively analysed within the field of endeavour in which they are engaged, such as anti-corruption.

In the empirical chapters of this dissertation, my writing style may sometimes appear to be somewhat journalistic. It is necessary to adopt this writing style in order to fully bring out the richness and diversity of the organisations being studied. It is through the elaboration of nuances and personal experiences, in addition to a discussion of hard data, that the reader can fully appreciate the phenomenon of atypical performance in dysfunctional environments. The inclusion of vignettes, snapshots and personal stories may sometimes appear to make the narrative fragmentary, and appear to be a departure from the dry, academic writing style that is common to PhD theses (Simmons, 2010, p.149). However, Mintzberg (1979, p. 587) makes a convincing argument for the inclusion of anecdotal evidence in theory-building research:

For while systematic data create the foundation for our theory, it is the anecdotal data that enable us to do the building. Theory building seems to require rich description, the richness that comes from anecdote. We uncover all kinds of relationships in our hard data, but it is only through the use of this soft data that we are able to explain them.

To ensure the synergy between the systematic and descriptive data, the narrative has been organised into internal and external factors. Organising the narrative in this way and supporting it with descriptive data will mean that the richness of the story can be fully brought out, without losing the underlying narrative coherence of the study (Simmons, 2010, p. 149).

At the end of the empirical work, I will be seeking to build theory from the case studies (Eisenhardt, 1989). This will not follow a traditional Grounded Theory approach (Strauss and Corbin, 1990), as I have started my search for answers from a number of propositions drawn from the literature and my own practitioner experience. Because the researcher is key instrument in case study research, the risk of bias is often higher than in quantitative 
research. It also often needs a deliberate effort to highlight and explain things that would be seen as 'common knowledge' in the study environment to a wider audience. As an example, while it is 'common knowledge' that public servants in Europe are protesting the increase in the retirement age across various countries, it is also 'common knowledge' that public servants in many African countries routinely falsify their dates of birth to allow them to work for longer. This is because the main benefit of being in post is not the salary that is earned but the power to award contracts and the corrupt financial benefits that that can confer, the generous travel allowances and the power to use the office for the benefit of relatives and family members. To make the point, I have deliberately not cited any references to support either of these two statements of 'common knowledge' here. In the rest of the dissertation, it is possible, and indeed likely, that I may have inadvertently, rather than deliberately, omitted to highlight or adequately explain all the idiosyncrasies of the environment in which the study is set.

\subsection{Case Selection Methodology}

Selecting the cases to study in this research was a challenging endeavour. The focus on performance in my research meant that I could not simply be purposive in my selection of cases (Blumberg, et al., 2008, p.253). I first had to show that any organisations selected were either atypical or typical based on some parameters, in an environment in which getting credible performance data is nearly impossible (Heymans and Pycroft, 2005, p.17), before I could start to determine why some organisations perform better than others. Many public service organisations in Nigeria do not collect any sort of data about how they perform against their mandates. Indeed, it was when I started requesting performance data against mandates that some organisations undertook to start collecting them from now on. Others saw the need to amend and update the information on their websites and in their publications to closer-reflect their current realities. No one asks for performance data, so most did not collect them.

Nigeria has 19 federal ministries and more than 400 agencies, as at January 2011. I have chosen not to focus on the federal ministries because I could 
find no perception data on, or evidence of, atypical performance in any one of them. Also, their performance was virtually impossible to assess with regards to what they were expected to deliver, as expected outputs are often not spelt out in tangibly measurable ways (Heymans and Pycroft, 2005, p.18). I therefore focused the research on agencies, since they are often set up, at least in principle, to do specific things and deliver specific outputs. Also, I could find examples of agencies that are perceived to be atypical performers and it is possible to verify their actual performance against their stated mandates with the use of targets and indicators.

I could find no reliable, up-to-date, comparable data on the performance of agencies in Nigeria, and, given the near total absence of even basic data, such as number of staff, number of service users, or quantum of internallygenerated revenue, it would have taken a herculean effort, beyond the capacity of a single researcher, to try and assess the performance of all the 400 agencies. In 2005, the government of Nigeria established a Service Compact with All Nigerians (SERVICOM) initiative which attempted some sort of measurement of all federal ministries, departments and agencies. However, the focus was entirely on front-office service windows and did not necessarily go to the main business of the organisation. Therefore, it was possible to have an electricity company with excellent customer reception facilities but which supplied little or no electricity, but would score well on the SERVICOM index. Conversely, you could have a revenue collection body that excelled on its core mandate but would score badly on the SERVICOM index because it did not have good customer reception facilities. Since the focus of my research is on outputs flowing from organisational mandates, using the SERVICOM data was inappropriate.

\subsection{Eligibility Criteria}

I have had to devise the following eligibility criteria to determine the cases that qualify for selection:

a) On the top of peoples' minds in perception surveys

b) Politically and/or economically important, based on government pronouncements 
c) Pair-able with another organisation that perform similar or identical functions, to enable comparison

d) Based on actual performance against mandates or stated targets, one organisation is atypical and the other is typical.

I have used the criteria sequentially, first to identify potential atypical performers and then to find suitable comparators for them. Firstly, focusing on organisations that are on the top of people's minds means that the outcome of my research is likely to have resonance with many people. While it is likely that public perception will be influenced by media activity, I have mitigated this by collecting actual performance data against mandates and targets. Secondly, focusing on those organisations that are of political and/or economic importance to the government makes it likely that government will find the research useful in replicating good performance. It also means that the study is not identifying good performers in areas that do not challenge the existing political economy or threaten the interest of the elite. Thirdly, ensuring that pairs of organisations are chosen in each field makes it possible to test the hypothesis that function is the key determinant of performance. Lastly, basing the final selection of cases on actual performance against mandates and targets removes any bias that may have informed the perception of respondents in the perception surveys.

\subsection{Applying the Eligibility Criteria}

In selecting my cases, I have adopted a four-stage process. The first stage was the analysis of perception data on the effectiveness of sixteen government organisations that were on the top of respondents' minds in a credible opinion poll. I then gathered data on the actual performance of those organisations that were perceived to be effective against their mandates and targets, since my definition of performance in this research is the extent to which a public sector organisation has achieved its predetermined goals with regards to its outputs. Thirdly, I applied a set of performance indicators drawn from the mandates and targets of those organisations, in the context of commonly-used indicators of performance for such organisations. For instance, an internal revenue service will 
primarily be concerned with the collection of tax revenue and a road safety organisation will primarily be concerned with reducing the incidence of road traffic accidents. Lastly, I triangulated all the information at my disposal with other perception surveys, performance data contained in annual reports and independent evaluations, statistics held by the National Bureau of Statistics, newspaper articles, academic research about the various organisations and exploratory interviews with people knowledgeable about the organisations. The sequence is set out in Figure 3 below (my own elaboration).

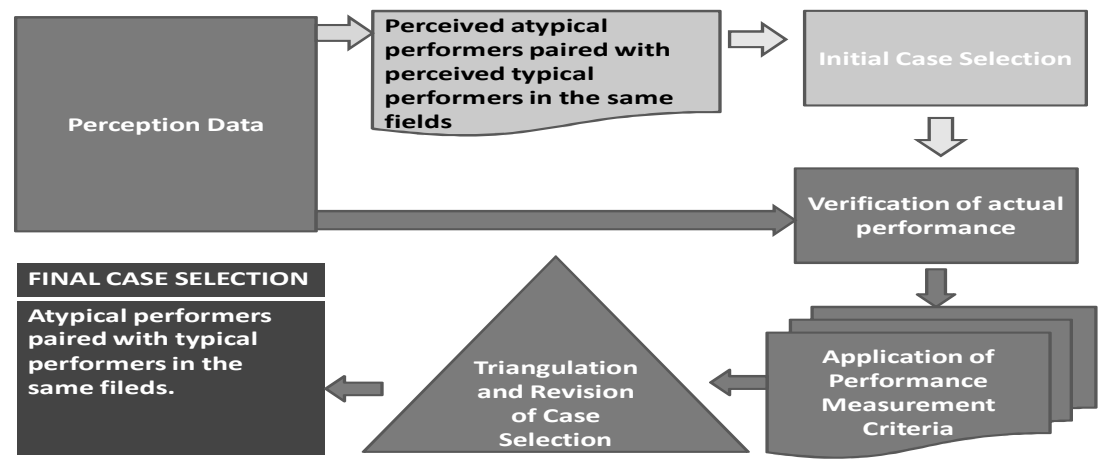

Figure 3: Case Selection Methodology

\section{a. Perception Data}

The most comprehensive perception data on the performance of federal agencies in Nigeria is the NOI/ Gallup polls on the Perceptions of Effectiveness, Confidence and Corruption in Government Institutions and Agencies in Nigeria, 2007, 2008 and 2009. The surveys covered 16 organisations on the top of respondents' minds each year, and involved face-to-face interviews with 2,000 people in all parts of Nigeria, using English and local languages. The survey methodologies were developed by the internationally-renowned Gallup Polls, and are robust. The survey sought the views of respondents on the effectiveness of government 
organisations and gave a score out of 100 to each organisation. The survey did not include a definition of effectiveness and relied on the respondents' interpretation of the meaning of the word. Generally, effectiveness refers to the successful achievement of goals. Therefore an organisation is said to be effective when it is successful at meeting organisational goals (Robbins, 1996). This is to be distinguished from efficiency which refers to meeting those goals at a low cost. The definition of effectiveness as the achievement of goals is consistent with the approach I have used in this study to determine the performance of organisations. Therefore the perception data in the NOI Polls is directly relevant to my study. Unfortunately, these surveys have not continued beyond 2009. Subsequent surveys have focused on topical issues in public discourse such as the approval ratings of the president.

A synthesis of the results from NOI Polls for the three years is depicted in Figure 4:

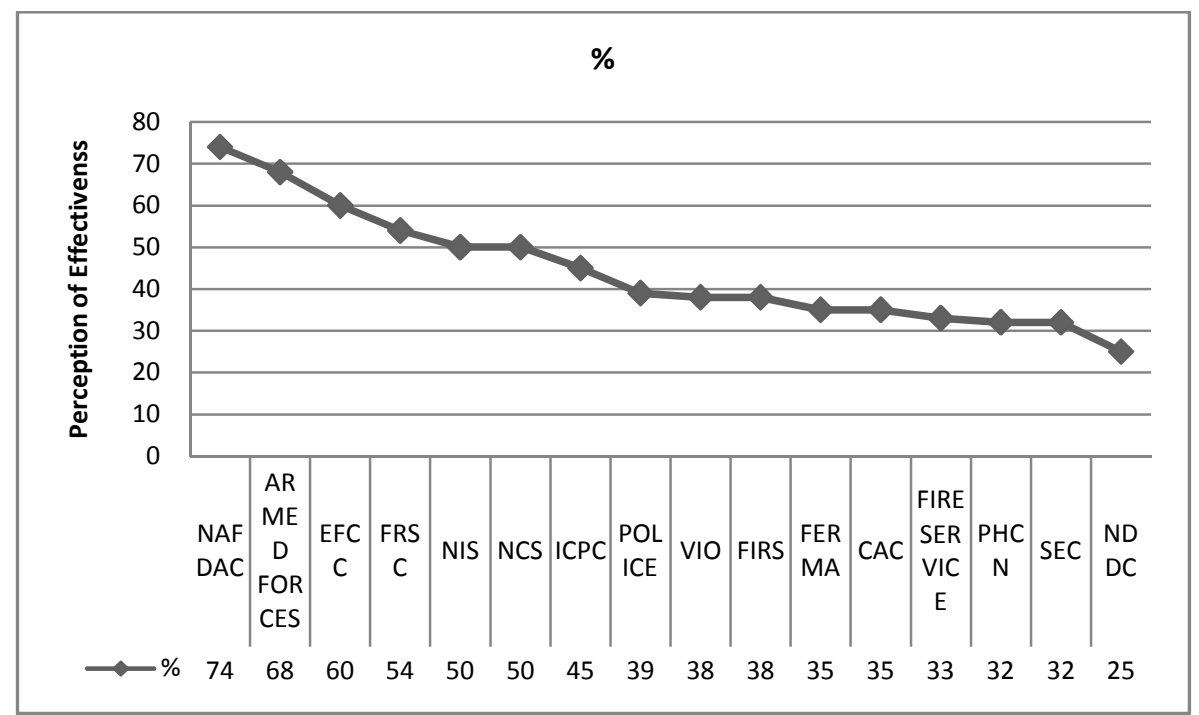

Figure 4: Perceptions of Effectiveness, Confidence and Corruption in Government Institutions and Agencies in Nigeria ${ }^{2}$

2 Source: Adapted from NOI Polls (2007; 2008 and 2009) 
Consistently, the results show that six of the sixteen organisations were perceived by at least $50 \%$ of respondents to be effective: the National Agency for Food and Drugs Administration and Control (NAFDAC), the Armed Forces (Army, Navy and Air Force), the Economic and Financial Crimes Commission (EFCC), the Federal Road Safety Corp (FRSC), the Nigerian Immigration Service (NIS) and the Nigerian Customs Service (NCS).

A deeper, statistical analysis of the results shows that the mean perception of effectiveness out of $100 \%$ is $44.18 \%$, with a standard deviation of $13.96 \%$. If we classify those scores which fall between the range of plus or minus 1 standard deviation from the mean (30\% to $58 \%$ ) as typical, we see that 12 out of the 16 organisations fall within this category. Only 3 organisations (NAFDAC, Armed Forces and EFCC) score higher than 58\%, and can therefore been considered as atypical. Only the Niger Delta Development Commission scored less than $30 \%$ and can be considered as worse than typical. $75 \%$ of the organisations sampled scored within the $30 \%$ to $58 \%$ range, which is higher than the $68 \%$ that would have been expected within the normal distribution shown in Figure 5. The effectiveness of 10 out of the 16 organisations was perceived to be below $50 \%$.

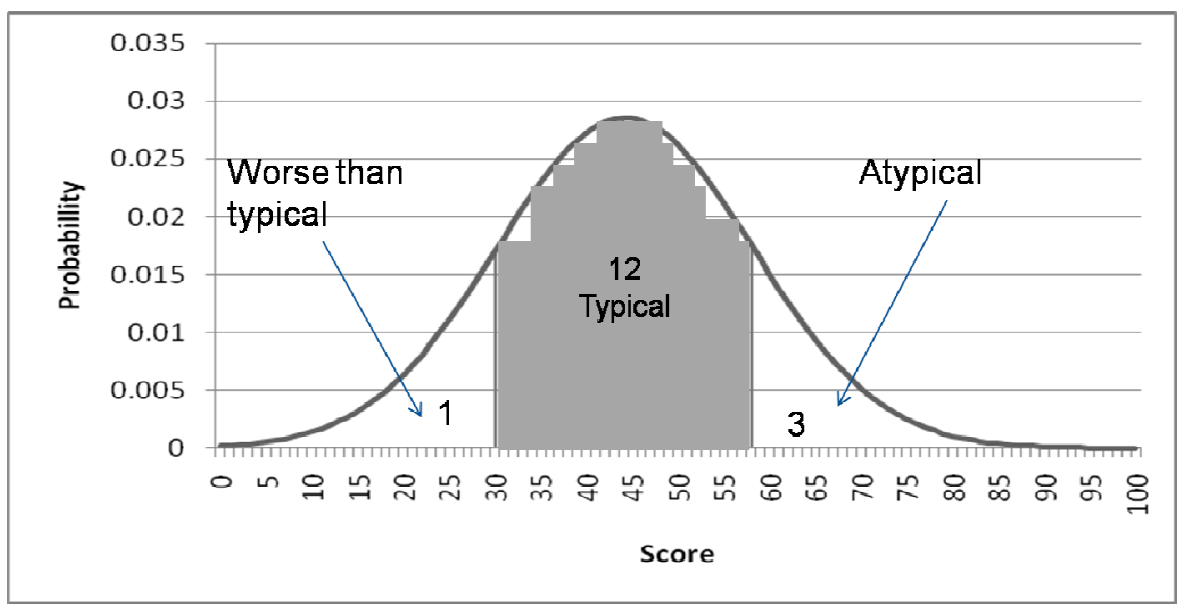

Figure 5: NOI Polls Distribution Curve ${ }^{3}$

${ }^{3}$ Adapted from NOI Polls (2007; 2008 and 2009). 
The three organisations that could be said to be atypical from the perception data are therefore NAFDAC, the Armed Forces and EFCC.

\section{b. Political and/or Economic Importance}

In determining political and/ or economic importance, I have relied on government pronouncements from 1999 to date. Each President of Nigeria has made pronouncements at their inauguration, on Independence Day or on other key occasions where they have set out the issues that are of importance to them. I have analysed all these pronouncements and found that the recurring themes are anti-corruption, improved governance, rule of law and raising non-oil revenue. ${ }^{4}$ These are consistent with the focus of international measurement tools for assessing the performance of governments. The Worldwide Governance Indicators (World Bank, 2010) measure performance in the areas of Voice and Accountability, Political Stability and Absence of Violence, Government Effectiveness, Regulatory Quality, Rule of Law, Control of Corruption. Of these, the outputs of particular organisations can most easily be assessed in the areas of Government Effectiveness, Regulatory Quality and Control of Corruption.

The African Peer Review Mechanism of the African Union (NEPAD, 2010) assesses the performance of African States in four areas: Democratic and Political Governance (including fighting political corruption), Economic Governance and Management (including fighting corruption and money laundering, and revenue administration), Corporate Governance (including the effectiveness of the regulatory framework), and Socio-Economic

\footnotetext{
${ }^{4}$ President Jonathan's inaugural speech, accessed from the internet on 23 May, 2011, at http://sahelblog.wordpress.com/2010/05/07/nigeria-president-goodluck-jonathans-inauguralspeech/; President Yar'adua's inaugural speech, accessed from the internet on 23 May, 2011, at http://234next.com/csp/cms/sites/Next/News/National/5564882-146/story.csp; President Obasanjo's 1999 inaugural address, accessed from the internet on 23 May, 2011, at http://maxsiollun.wordpress.com/2009/05/30/10th-anniversary-of-nigeria $\%$ E2 $\% 80 \% 99$ s-returnto-democracy/
} 
Development (including promoting self-reliance and self-sustaining development, e.g., through a focus on internally generated revenue).

The Ibrahim Index (Ibrahim Foundation, 2010) for assessing the performance of African States focuses on Safety and the Rule of Law (including Accountability and Corruption), Participation and Human Rights, Sustainable Economic Opportunity (including the focus on internally generated revenue) and Human Development.

Issues such as Voice and Accountability, Political Stability, Participation and Human Rights and Democracy and Political Governance are difficult to tie to particular government organisations, since various institutions and organisations are at play. Therefore in looking at the performance of government organisations with regards to outputs, it would be more sensible to look at those results for which the organisations are directly responsible.

NAFDAC is politically and economically important. Weak governance environments are often weak on the enforcement of regulations, and the successful enforcement of standards by one organisation is therefore suggestive of atypical behaviour. The political elite are often behind the counterfeiting of drugs and the importation of substandard goods. Therefore, for an organisation that is fighting against counterfeiting to be successful, it must be overcoming political economy constraints in the system. It is interesting to study how and why this is happening, in the context of understanding how good practice in some organisations can be replicated more widely.

Given that Nigeria's democracy is a little over ten years old, after long years of military rule, the military is still highly politically relevant. Indeed, as at Nigeria's 2011 elections, several retired military officers who had been in previous military governments were still running for elective office. The corrupt military regimes that they ran, and the formidable financial resources that they amassed, also means that the armed forces still play a major role in the political economy of the country. Of course, the armed forces play an important role in providing the stable and secure environment for economic activity to thrive. 
The Economic and Financial Crimes Commission is politically and economically important. Corruption is often a major reason for weak governance in many developing countries. Ratings on the prevalence of corruption, like those of Transparency International, affect the country's image in the international community and the prospects for attracting foreign investment. It is also hugely politically important, as the credibility of the government often depends on the efforts it is seen to be making in fighting corruption.

\section{c. Pairs of Organisations Performing Similar Functions}

NAFDAC was established to control the manufacture, importation, exportation, distribution, advertisement, sale and use of food, drugs, cosmetics, chemicals, medical devises and packaged water. The National Agency for Food and Drugs Administration and Control Act of 1993 (Federal Government of Nigeria, 1993), gives the organisation wide-ranging powers to intercept, confiscate and destroy counterfeit drugs and close down factories that produce substandard drugs. NAFDAC can be paired with the Standards Organisation of Nigeria (SON). The Standards Organisation of Nigeria Act, 1990 (Federal Government of Nigeria, 1990) vests SON with the responsibility of standardising and regulating the quality of all products in Nigeria. It has powers to seize, confiscate and destroy all substandard products. Its remit covers everything not covered by NAFDAC and includes textiles, vehicle spare parts, building material, chemicals, electrical appliances, and computing equipment. NAFDAC and SON are in the same field of regulation and NAFDAC was created to focus on a subset of SON's original mandate. Although SON was not covered in the NOI polls on which the initial case selection was based, it is the most natural pair for NAFDAC. While NAFDAC focuses mainly on food and drugs, SON has a wider remit that covers all substandard products. SON has existed since 1971 and the setting up of NAFDAC in 1993 is suggestive that the government wanted more done to combat the menace of fake drugs.

The armed forces are not one homogenous organisation. The term 'armed forces' is used in Nigeria to refer to the army, navy and air force. 
Respondents in the NOI Polls survey did not distinguish them as distinct organisations which are likely to have differentiated performance. The armed forces perform unique functions and its constituent organisations cannot easily be paired with any other organisation. Additionally, it will be difficult to assess their performance against their mandates in terms of outputs. As specific organisations are my unit of analysis, I have discounted the armed forces from this study.

The Economic and Financial Crimes Commission Establishment Act 2004 (Federal Government of Nigeria, 2004a) mandates EFCC to fight economic and financial crimes by preventing, investigating, prosecuting and penalising financial crimes and money laundering. The Independent Corrupt Practices and Other Related Offences Commission Act of 2000 mandates the Independent Corrupt Practices Commission (ICPC) to prohibit and prescribe offences for corrupt practices and other related offences. EFCC and ICPC perform broadly similar functions and is a natural pair for this study.

\section{d. Actual Performance Compared to Perception Data}

Having discounted the armed forces, I then ascertained and compared the actual performance of NAFDAC and SON, and EFCC and ICPC for 5 years, between 2005 and 2009. To determine actual organisational performance, I have set out performance indicators for verifying the perception data for each public service field. These indicators are drawn from the laws setting up the organisation, their stated objectives and key performance targets and commonly-used performance indicators for assessing the performance in the respective various fields. Using actual verifiable performance data against mandates eliminates the risk that public perception may have been influenced by clever and sustained publicity campaigns. It goes to the issue of the outputs delivered by the organisation and whether or not it is really effective at doing what it was created to do. For regulatory quality (NAFDAC and SON), I have simply used the prevalence of fake drugs or substandard goods and for anti-corruption I have used prosecution-toconviction rates and amount of money recovered. 


\section{Pair 1: EFCC and ICPC}

Between 2005 and 2009, EFCC secured 400 convictions from 700 prosecutions, a success rate of $57 \%$. It also recovered $\$ 6.5$ billion from corrupt individuals. ICPC, on the other hand only secured 35 convictions from 255 prosecutions, a success rate of just $14 \%$. It has also only recovered $\$ 100$ million. EFCC is, therefore, outperforming ICPC in the two performance indicators used: prosecution-to-conviction rates and money recovered. The performance indicators used assessed performance on the core mandates of both organisations. I have not measured their efforts on educating members of the public to shun corruption, although it is one of the activities that both organisations undertake. This is because of the difficulty in measuring the effectiveness of that activity as an output, beyond the use of perception data. However, even on the awareness of the public on the existence of EFCC and ICPC, $59 \%$ of respondents were aware of EFCC while only $46 \%$ were aware of ICPC (CLEEN Foundation, 2005). This is although the ICPC was established before the EFCC, and the EFCC had only been operational for one year at the time that the survey was conducted. Another survey in 2009 showed that 99\% of businesses in Nigeria were aware of the work of EFCC, compared to just 3\% for ICPC (NBS/EFCC, 2007).

\section{Additional Information and Triangulation}

The United Nations Office on Drugs and Crime, in its 2008 Annual Report, rated EFCC as "the most effective anti-corruption agency in Africa" (UNODC, 2008, p. 44).

Similarly, a 2009 survey by the National Bureau of Statistics and the European Union shows that, at 52\%, business organisations perceived EFCC to be the best-performing and most honest organisation among the 11 organisations surveyed. ICPC was perceived to be well- performing only by $17 \%$ of business organisations surveyed (UNODC, 2009).

Also, the Convention on Business Integrity carried out an independent perception survey on the performance of anti-corruption agencies in 2007 and 2008. It sampled 1000 stakeholders and $72 \%$ of respondents believed that EFCC was "truly fighting corruption". By contrast, only $3 \%$ of the same 
respondents perceived ICPC to be truly fighting corruption (Convention on Business Integrity, 2009, p. 85). In its first four years of existence, ICPC did not record a single conviction.

My own experience of both organisations has been that, while the official performance data of EFCC was readily available on their website and in other publications, data on ICPC's performance was tortuously difficult to obtain. This is despite the fact that information about the number of cases prosecuted, number of convictions secured and amount of money recovered should be readily available to members of the public. In summary, it is defensible to say with a high degree of confidence that the EFCC is an atypically well-performing organisation, while the ICPC is a typical Nigerian organisation.

\section{Pair 2: NAFDAC and SON}

NAFDAC's main role, from its enabling law, is to regulate and control the importation, exportation, manufacture, advertisement, distribution, sale and use of food, drugs, cosmetics, medical devices, bottled water and chemicals. It is also mandated to carry out tests and ensure compliance with standard specifications.

The role of SON is to prepare standards for products and processes for ensuring compliance and quality assurance for locally manufactured and imported products and services throughout the country. It is also to ensure compliance of imported goods with technical standards/ specifications in order to prevent importation and distribution of substandard products into the Nigerian market.

As at the end of 2009, NAFDAC had reduced the prevalence of fake drugs from $41 \%$ in 2002 to $16 \%$ the last time it was measured in 2006 (Akunyili, 2010). On the other hand, there was evidence that the incidence of counterfeit goods, regulated by SON, was actually increasing (Nigerian Tribune, 2010). Therefore, while NAFDAC has drastically reduced the incidence of fake drugs over the last few years, SON has not been as effective in reducing other types of counterfeiting. 


\section{Additional Information and Triangulation}

An independent assessment of drug use in Nigeria supports NAFDAC's claims about significant reductions in the prevalence of fake drugs in Nigeria. A sample of drugs tested by an international team of experts showed a failure rate of just 18\% (Bate, et al., 2009). In the 2008 Report of the International Narcotics Control Board (United Nations, 2009), the Board commends the efforts of NAFDAC in tacking counterfeit drugs. The United Nations Office on Drugs and Crime rated Nigeria as West Africa's most effective drug control and enforcement country, and commended the work of NAFDAC (This Day, 2009).

Independent views about the effectiveness of SON have been uncomplimentary. Comments in the press include: "SON seems to be docile, ineffective and silent as a barrage of substandard products come into the country on a daily basis" (Nigerian Tribune, 2010); and "[...] it would seem that SON had either completely abandoned its responsibilities or been simply overwhelmed by them" (This Day, 2009a).

When all these factors are considered alongside the fact that in the NOI/Gallup Polls, NAFDAC has been perceived to be the most effective organisation in the country for three years running, it provides adequate justification for asserting that NAFDAC is an atypically good organisation.

\section{Replacement for the Armed Forces}

Having discounted the Armed Forces from the study, the three other organisations that were rated by more than $50 \%$ of respondents to be effective were the FRSC, NIS and NCS. I therefore considered selecting one of these three organisations to replace the Armed Forces. Although the FRSC was on the top of people's minds, being that their officials are visible on the streets, I found no evidence that the commission was politically or economically important in the context of Nigeria. More importantly, the perception that the FRSC is performing well was not borne out by actual performance data, as the rate of accidents, and fatalities from them, is actually increasing (National Bureau of Statistics, 2010). Reducing the rate of 
road accidents and the fatalities from them is the reason why the FRSC was created.

The perception that FRSC is effective could have been created in the minds of the public by the fact that they are sometimes on the roads checking drivers for proper documentation. However, in Nigeria, there are no driving tests, no roadworthiness tests for vehicles and it is possible to obtain a drivers licence without being able to drive a car. Evidence that the rate of accidents and fatalities have been increasing year-on-year makes it impossible to justify the perception rating for FRSC as an effective organisation. The Nigerian Police which would be the comparator organisation is even worse, as the Annual Abstract of Statistics 2005-2009 shows that the general crime rate and the rate of serious crimes have also been increasing year on year. I therefore could not find a comparator organisation that is performing effectively based on actual performance against its mandate. Therefore, the FRSC did not meet two out of my four eligibility criteria. It was not politically or economically important and its actual performance did not support the perception that it is effective. I therefore discounted FRSC from the study.

The two remaining organisations that scored more than $50 \%$ were the NIS and NCS. Immigration is a major political issue in most countries and the regulation of imports and the revenue from import and export duties is a significant economic issue. The passport service of the NIS is essentially a service delivery function, as the issuance of passports could easily be paired with the issuance of business licences by the Corporate Affairs Commission which is one of the organisations in the NOI Polls survey. However, the NIS does not keep any records about the effectiveness of its passport service. For instance, there are no records on number of passports issued, speed of processing, level of complaints or rate of customer satisfaction, which are the tangible outputs against which their performance could be measured. Having publicly undertaken to process passport applications within five days, the NIS does not collect information about its performance against this target. It was, therefore, impossible to confirm their performance and compare it with the perception data. For this reason, I discounted the NIS.

The NCS, apart from regulating the import and export of goods, has as its main objective the generation of revenue. This made it possible to pair it 
with another revenue administration function in the survey - the Federal Inland Revenue Service. A basic fact of governance is that, even in the richest economies, there is never enough money to solve all the problems facing society. This means that effective and efficient revenue administration is of key economic importance in most countries. Various policy documents in Nigeria, such as the National Economic Empowerment and Development Strategy (Federal Government of Nigeria, 2004c), identifies the need to grow non-oil revenue as one of paths to development. I therefore considered NCS and FIRS as a suitable replacement for the Armed Forces. The next section justifies my selection of one of them as an atypical performer and the other as typical.

\section{Pair 3: Federal Inland Revenue Service (FIRS) and NCS}

The NCS has existed in various forms since 1891. The Customs and Excise Management Act, 2004, gives the NCS two main statutory functions. The first is to collect and account for revenue, and the second is to prevent the illegal entry of goods into the country. It is allowed to collect import duty, excise duty and other customs fees and levies.

The Federal Inland Revenue Service came into being in 1993 as the operational arm of the Federal Board of Inland Revenue, which was a statutory creation of the Companies Income Tax Act \#22 of 1961 (Federal Inland Revenue Service, 2004). The Federal Inland Revenue Service (Establishment Act), 2007, mandates FIRS to collect and account for the specific taxes that are set out in its Act. These include personal income tax, company income tax, petroleum profit tax and value added tax.

FIRS and NCS perform similar functions regarding revenue collection at federal level and are a natural pair for this study. Table 3 sets out the performance of both organisations against the official annual targets set for them by the Federal Ministry of Finance. Details of actual collection performance have been obtained from officials in both organisations.

From the NOI Polls survey, the NCS is perceived by $50 \%$ of respondents to be effective while the FIRS is only perceived by $38 \%$ of respondents to be 
effective. However, when I collected information about the actual performance of both organisations against mandates and targets, it became obvious that FIRS is clearly outperforming the NCS. Indeed, it is exceeding its own targets and the targets set by government and can rightly be considered an atypical organisation. The NCS is only collecting two-thirds of its estimated collection potential. The estimated collection potential is not arbitrarily set by the Ministry of Finance but is set in consultation with the organisations concerned, taking on board historical performance, inputs and planned improvements. Table 1 sets out the actual performance figures for both organisations.

\begin{tabular}{|l|l|l|l|l|}
\hline Organisation & $\begin{array}{l}\text { Perception of } \\
\text { Effectiveness (out } \\
\text { of 100\%) in NOI } \\
\text { Polls }\end{array}$ & $\begin{array}{l}\text { Total Estimated } \\
\text { Collection } \\
\text { Potential (2005 } \\
\text { to 2009) }\end{array}$ & $\begin{array}{l}\text { Actual } \\
\text { Collection (2005 } \\
\text { to 2009) }\end{array}$ & $\begin{array}{l}\text { Percentage } \\
\text { estimated } \\
\text { to actual }\end{array}$ \\
\hline FIRS & $38 \%$ & $\$ 69$ billion & $\$ 70.7$ billion $^{5}$ & $102 \%$ \\
\hline NCS & $50 \%$ & $\$ 118$ billion & $\$ 79$ billion $^{6}$ & $66 \%$ \\
\hline
\end{tabular}

Table 1: Actual Performance of FIRS and NCS7

\section{Additional Information and Triangulation}

Comparing the actual performance figures to the perception figures from NOI Polls, it is clear that the negative perception of FIRS among members of the public is misplaced. To exceed collection targets for tax revenue, in an environment where people feel that they should not have to pay tax since the country has oil, is no mean feat. In the first eight months of 2010, FIRS

\footnotetext{
${ }^{5}$ My computation of revenue collection targets and actual collection figures from official records of FIRS.

${ }^{6}$ My computation of revenue collection targets and actual collection figures from official records of the Budget Office of the Federation.

${ }^{7}$ My compilation of performance data from the Office of the Accountant General of the Federation and the Budget Office of the Federation.
} 
announced that it is on course to collect double its 2009 revenue figures by the end of 2010 (Daily Trust, 2010). The media has described the improvements in FIRS as "a quiet revolution" and say that the organisation has tripled the revenue accruable to government, consistently exceeded the targets set by the Federal Ministry of Finance, and always exceeded its Chairman's even-higher targets. Perhaps the quietness of the "revolution" in FIRS is what has informed the low ratings given it by members of the public in the NOI Polls.

Conversely, interviewees knowledgeable about NCS performance suspect that it may actually collect far more revenue than it declares, with a sizeable proportion going into private pockets. While it was not possible to confirm or discount this suspicion, it is noteworthy that the last two Comptroller Generals of Customs are being prosecuted for official corruption (Next Newspaper, 2010), and the current one is under investigation for allegedly bribing legislators to suppress weak performance figures (Nigeria Compass Newspaper, 2010). It has therefore been necessary to take a realist view of the performance information, beyond the official performance data about the organisations, in arriving at a sensible view about comparative performance.

My experience of FIRS is one of an organisation that has transformed itself into one of the highest-performing organisations in Nigeria, with regards to delivering its intended outputs. It is for all these factors that I feel confident to assert that FIRS is an atypically-good organisation while the NCS is a typical Nigerian organisation.

FIRS also appears to have all the ingredients of atypical government demand, including new powers, autonomy and freedom to recruit and pay competitive wages. The Nigeria Customs Service appears to have much of the same ingredients but does not appear to be as effective or efficient, in terms of revenue administration. This makes the two organisations an interesting comparison in the context of this research.

To ensure that I did not overlook any potentially atypical organisation, I sought actual performance data for all the remaining organisations in the NOI Polls survey. In most cases, there was no data available on actual performance against mandates or targets, where those mandates or targets 
exist. Where data was available, it suggested that the perception of respondents on their lack of effectiveness were validly held.

The cases chosen for this research are therefore EFCC and ICPC, NAFDAC and SON, and FIRS and NCS. Their respective fields of focus are Anti-corruption, Regulatory Quality and Revenue Administration.

In sequencing the case studies, I started with EFCC because my theoretical propositions about demand appear to be most strongly supported in that case study. Because EFCC could be said to have been designed from inception to be atypical, I next studied NAFDAC which had existed for much longer but had performed typically for most of its existence before transforming itself into an atypical performer. Having studied EFCC and NAFDAC where there was a clear public desire for improvement, I lastly studied FIRS which performs a function that most people are not enthusiastic about (collecting taxes) to see whether the theoretical propositions still held. This sequencing resulted in the pattern-matching logic (Yin, 2009, p. 136) shown in Figure 6 below. Pattern matching logic compares an empirically based pattern with a predicted or theoretical one.

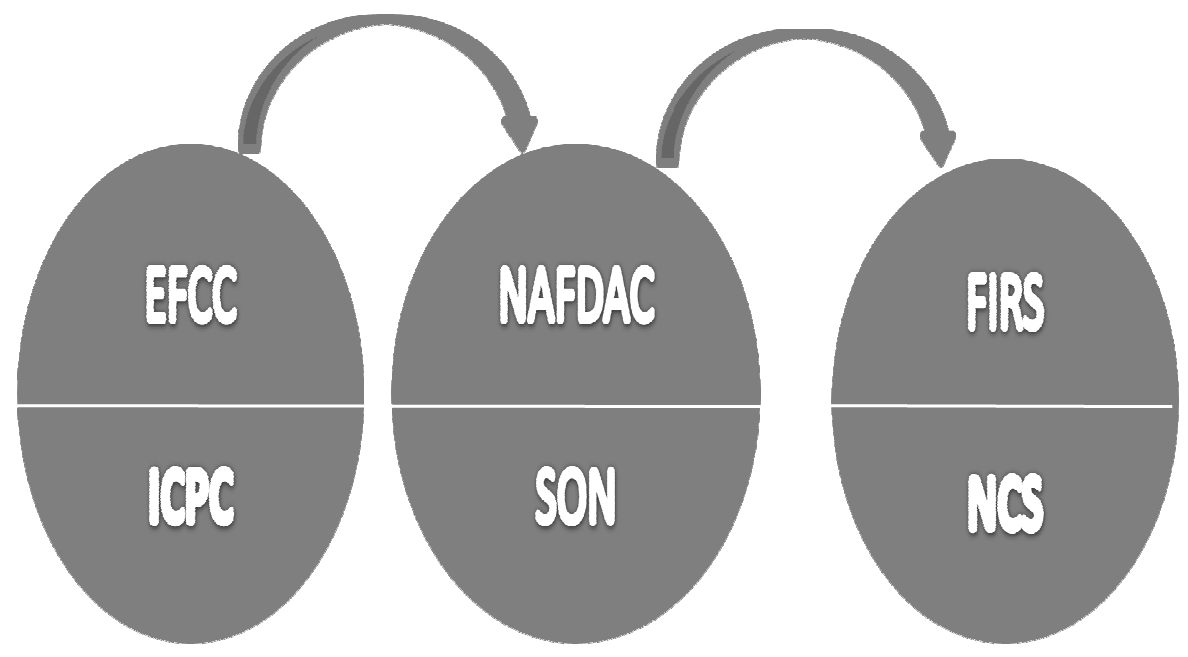

Figure 6: Pattern-matching Logic 
Each case study follows the following outline:

1. Abstract

2. Introduction

3. Organisation 1

a. Brief History

b. Function

c. Mode of Operation

4. Organisation 2

a. Brief History

b. Function

c. Mode of Operation

5. The Dependent Variable

6. Application of Explanatory Variables

7. Demand

8. Methodology (including the list of people met)

9. Conclusions

\subsection{Data Collection}

The research is designed primarily as a comparative case study of selected typical and atypical organisations, to examine the phenomenon of atypical performance in its real-life context, especially as there is a plethora of theories about how the phenomenon comes to exist in dysfunctional environments.

I conducted the fieldwork for this research using the following tools:

- Literature review of pertinent publications and Exploratory Interviews

- Semi-structured interviews

- Focus Group Discussions

- Observation

Using the Exploratory Interviews, I ensured that participants for the semistructured interviews and focus group discussions are selected based on 
their familiarity with how and when atypical performance came about, or ceased to be, in each particular case; the interventions that led to it; and their views on how atypical performance could be sustained and replicated elsewhere.

\section{Lines of Enquiry}

During the fieldwork, I explored the following issues, inter alia, that are directly linked to my Conceptual Framework in Chapter 2:

- What were the sources of the demand for improvement, if any?

- Was a conscious decision to seek improvements taken at any specific point in time?

- If a decision to improve was taken at any point in time, when was the decision taken, by whom and why?

- What is the hierarchy of factors that affected that decision?

- If there was no specific decision to improve, what factors led to the organisation's improvement?

- Where applicable, why were the elite willing to give up some of their power to one organisation but not to another similar organisation?

- Where applicable, how was the organisation able to overcome political and institutional constraints to still achieve its outputs?

- How has the organisation managed to persist as an atypical or typical performer?

- Has the organisation triggered improvement in similar/other organisations? If so, what improvements and how?

- Under what policy, regulatory and institutional conditions does the organisation exist?

- What are the internal management arrangements, structures and approaches used by the organisation and what resources are available to it to deliver its mandate?

- Leadership

- Management (including Funding, Recruitment Processes, Performance Management, and Pay and Conditions of Service)

- Technical Capacity 


\section{- Public Support}

There are various sources of information and the data has had to be triangulated to get a true empirical picture of the phenomenon. I obtained information from seven groups of respondents for each field:

- Ministers and top politicians

- Past and present chief executives

- Officers in the organisation - low, middle and managerial levels

- Civil Society and Media representatives

- Private Sector Representatives

- Donors

- Service Users

Where possible, I started the fieldwork in each field by conducting the elite/ decision-maker interviews first. Next, I interviewed donor representatives, civil society/ media representatives, private sector representatives and service users. This was for the purpose of ascertaining the sources of demand for improvement, if any. Lastly, I interviewed officers in each organisation to get a true sense of how the organisation works from the inside, and the various factors at play that affect performance. Where possible, I conducted focus group discussions with officers at various levels in each organisation to ensure that I was getting a balanced view of the organisation. However, given the availability of senior people, it was not always possible to stick rigidly to a set order of meetings. Table 2 sets out the various interviewee groups, the areas of interest on which information was sought, and the means used to obtain the information from the respondents that I sought to interview in each case. For pragmatic reasons, I have simply interviewed as many of each respondent group member as I could, over a 14-month period from January 2011 to March 2012.

The case studies themselves each contain a Methodology section that describes what was actually done in the field in each case study. Table 2 sets out the approach taken and the epistemological interests pursued. 


\begin{tabular}{|c|c|c|}
\hline Respondent Group & Epistemological Interest & Tool \\
\hline $\begin{array}{l}\text { Relevant Ministers } \\
\text { and Top Politicians }\end{array}$ & $\begin{array}{l}\text { - The source of pressure/ demand } \\
\text { for change/ political environment } \\
\text { prior to reforms } \\
\text { - If and when a decision for } \\
\text { improvement was made, why and } \\
\text { by whom. } \\
\text { - How the conditions for } \\
\text { improvement came into play. } \\
\text { - Hierarchy of conditions }\end{array}$ & $\begin{array}{l}\text { Semi-structured } \\
\text { interviews }\end{array}$ \\
\hline $\begin{array}{l}\text { Past and Present Chief } \\
\text { Executives }\end{array}$ & $\begin{array}{l}\text { - The source of pressure/ demand } \\
\text { for change. } \\
\text { - If and when a decision for } \\
\text { improvement was made, why and } \\
\text { by whom. } \\
\text { - How the conditions for } \\
\text { improvement came into play. } \\
\text { - Hierarchy of conditions }\end{array}$ & $\begin{array}{l}\text { Semi-structured } \\
\text { interviews }\end{array}$ \\
\hline $\begin{array}{l}\text { Officers } \\
\text { Low, Middle and } \\
\text { Management Level } \\
\text { Staff }\end{array}$ & $\begin{array}{lll}\text { - } & \text { External and Internal Factors } \\
\text { affecting performance } & \\
\text { - } & \text { Internal organisational and } \\
& \text { management arrangements }\end{array}$ & $\begin{array}{l}\text { Semi-structured } \\
\text { interviews and Focus } \\
\text { Groups }\end{array}$ \\
\hline $\begin{array}{l}\text { Civil Society/ Media } \\
\text { Representatives }\end{array}$ & $\begin{array}{l}\text { - The source of pressure/ demand } \\
\text { for change } \\
\text { - Hierarchy of conditions }\end{array}$ & $\begin{array}{l}\text { Exploratory Interviews } \\
\text { and Focus Group } \\
\text { Discussions }\end{array}$ \\
\hline $\begin{array}{l}\text { Private Sector } \\
\text { Representatives }\end{array}$ & $\begin{array}{l}\text { - The source of pressure/demand } \\
\text { for change } \\
\text { - Hierarchy of factors }\end{array}$ & $\begin{array}{l}\text { Exploratory Interviews } \\
\text { and Focus Group } \\
\text { Discussions }\end{array}$ \\
\hline Donors & $\begin{array}{l}\text { - } \begin{array}{l}\text { Source of pressure/ demand for } \\
\text { change and role of donors }\end{array} \\
\text { - Hierarchy of conditions }\end{array}$ & $\begin{array}{l}\text { Exploratory and Semi- } \\
\text { structured interviews }\end{array}$ \\
\hline Service Users & $\begin{array}{l}\text { - } \begin{array}{l}\text { Source of pressure/ demand for } \\
\text { change }\end{array} \\
\text { - } \quad \text { Hierarchy of conditions }\end{array}$ & $\begin{array}{l}\text { Focus } \\
\text { Discussions }\end{array}$ \\
\hline
\end{tabular}

Table 2: Interview Approach and Epistemological Interest 


\subsection{Data Analysis and Causation}

In analysing the data collected, I worked the key elements of my Conceptual Framework through the three organisational fields of anti-corruption, regulatory quality and revenue administration. The key conditions to track, and around which the analysis will be done, are set out in Figure 7.

In analysing the empirical data collected from the case studies, I sought to understand for each case study what the general environment was before any intervention, the national and global conditions, any demand for improvement, the key institutional and organisational interventions that affect performance, and the consequences and results of this chain of events. If the patterns match for the atypical organisations, the results will help strengthen the internal logic of the study (Yin, R.K., 2009). If the conditions that caused atypical performance do not exist in the typical organisations in each field, it will provide external validity to my findings. My data analysis methodology is depicted in Figure 7 below.

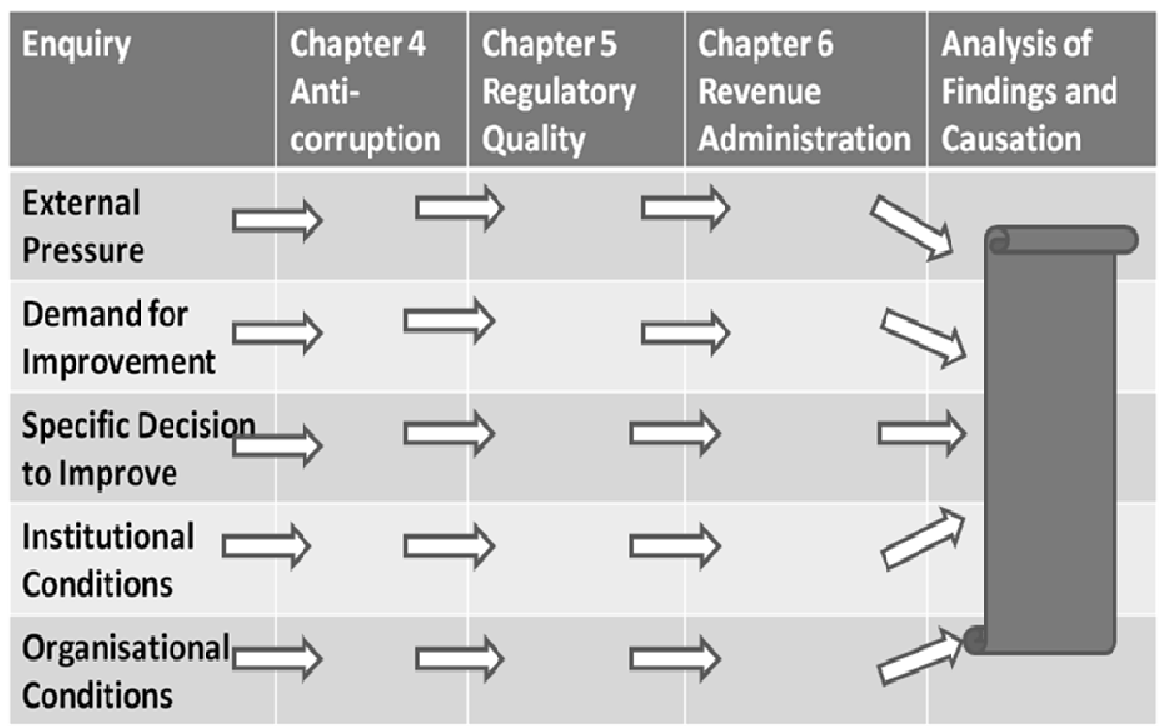

Figure 7: Data Analysis Methodology 


\subsection{Indicators for Testing the Existence of Demand}

In order to ascertain whether or not there was a demand for improvement in each case, I have developed the following indicators:

\section{Government Demand}

- Government pronouncements on the need for change

- Creation of new organisation to tackle a long-existing problem

- Enactment or strengthening of relevant legislation, or the abolition of constraining legislation

- Appointment of an effective leader based on antecedents, qualifications and merit

- Granting the organisation an unusual level of freedom - to hire staff, pay staff better and take risks

- Significant increase in financial resources through budgetary provision

\section{Private Sector Demand}

- Representations to government in the form of communiqués, memos, direct meetings and trade delegations

- Funding for and support to advocacy groups

\section{Donor Demand}

- Programmes designed around the issues

- Publications and use of data to advocate for change

- Support and funding to special interest groups to advocate for change

\section{International Community Demand}

- Bilateral and multi-lateral treaties and agreements

- Pronouncements of international bodies, such as the United Nations

- Pressure from international media, rating organisations (such as Transparency International) and the existence of sanctions 


\section{Media/ Pressure Groups Demand}

- Frequent publications about subject matter

- Media campaigns

- Demonstrations

\section{Service User and Citizens Demand}

- Complaints

- Non compliance

It is not possible to use these indicators in a deterministic way, or to assign mathematical values that calculate a threshold or tipping point. Instead they will be used to paint a picture of the organisation in conjunction with other data that emerge during the fieldwork.

\subsection{Conclusions}

The study is first an empirical one. I have designed it such that I can identify and isolate the conditions that, with some regularity, can produce approximate generalisations (Mills, 1987, p.48). Beyond these though, is the need to look for causation - the reasons why the conditions interact with themselves in the way that they do. I have therefore applied a Realist epistemology in the interpretation of the findings (Sayer, 2010). "The concept of absolute truth is incoherent. All knowledge is fallible, though not equally so" (Sayer, 2010. p.205). Realism will help to explore the motivation of key individuals, the application of individual and collective will and their influence on causality and consequences (Mills, 1987, p. 50).

In summary, this chapter describes my research approach and the rationale for the methodological decisions that I made in this study. It describes, in some detail, the challenging process of selecting suitable cases to study, and explained how the data on the cases will be collected and analysed. The application of my conceptual framework in Chapter 2 to link my research 
Chapter 3. Research Design and Methodology: Organised Scepticism 85

design and methodology in the anti-corruption field is the focus of Chapter 4. 


\section{Chapter 4 Anti-Corruption: Swimming Against the Tide}

You need to do ten times what is ordinary in this environment to get anything done. You need to be a little crazy (Ribadu, 2010). ${ }^{8}$

This chapter applies the Conceptual Framework set out in Chapter 2 to my research design and methodology in Chapter 3, in the context of anticorruption. It studies two organisations: the Economic and Financial Crimes Commission (EFCC) and the Independent Corrupt Practices and Other Related Offences Commission (ICPC). The chapter starts with an abstract that sets out the key issues to be addressed. It then sets out the background and history of each organisation and explores the application of the explanatory variables for this research to my research question. Next, the findings about why one organisation performs better than the other are analysed and explained. Finally, my hypotheses relating to demand are further developed.

\subsection{Abstract}

This case study examines how Nigeria went from being the most corrupt country in the world in 1997, to being the $9^{\text {th }}$ most corrupt in 2007 and then dramatically raising its anti-corruption rating to being only the $5^{\text {th }}$ most corrupt country in 2008. It shows that although the ICPC existed since 2000, it was probably the creation of EFCC, rated as the most effective anticorruption agency in Africa, that catalysed the country's fight against corruption. The two organisations being studied here are the two main anticorruption bodies in Nigeria. While there are many differences between the two organisations (including leadership, management practices, funding, and levels of donor support), my main finding is that the key difference

\footnotetext{
${ }^{8}$ Interview with me on 7 December, 2010.
} 
between them is that EFCC's performance was conditioned by demand, and the convergence of favourable institutional and effective organisational conditions. The convergence of these three ingredients are absent in ICPC.

\subsection{Introduction}

Corruption lies at the heart of the underperformance of public sector organisations in many developing countries (Ikubaje, 2006, p.1). Indeed, corruption thrives due to the unwillingness or inability of public sector organisations to perform the roles for which they were set up. The checks and balances that should be in place to guard against public excesses are often bypassed and public servants can view the holding of public office as an opportunity for self-enrichment. Conversely, because many public sector organisations do not fulfil their mandates, members of the public are forced to pay bribes before they can receive the services that they should otherwise receive as a matter of course. Public servants set up toll gates to extract rents from the public and even the pensions of former public service colleagues are embezzled and the ability of government to deliver public goods constrained. This cycle mutually reinforces itself and the result is a public service that can appear to serve the public servant, rather than the public.

Corruption has a number of significant consequences. It reduces government revenue, lowers incentives to private investment, distorts the composition of government expenditure, undermines the legitimacy and credibility of the state and erodes the moral fabric of society (Adamolekun, 2011).

Despite the progress that it has made in the fight against corruption, Nigeria continues to be perceived as one of the most corrupt countries in the world (Convention on Business Integrity, 2010, p.7). Transparency International rates the perception of corruption in many countries and Nigeria's ratings have been generally poor. Figure 8 shows how Nigeria has fared out of a possible 10 points on the ratings since 1996. 


\section{NIGERIA - CORRUPTION PERCEPTION INDEX (CPI) 1996 - 2010}

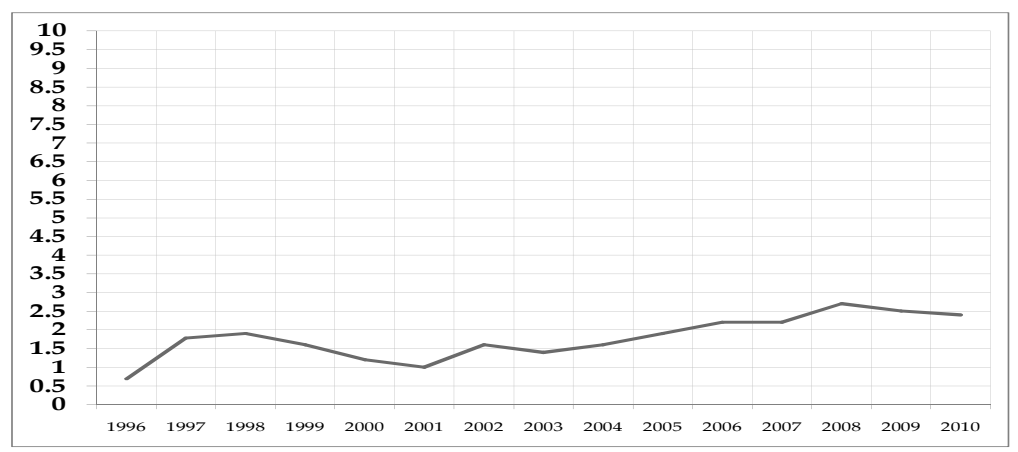

Figure 8: Nigeria's Corruption Perception Index 1996-20109

Nigeria has had anti-corruption laws dating back at least to 1944 when the Criminal Code was enacted. An important distinction of the Corrupt Practices and Other Related Offences Act (CPA) 2000 is its establishment of a dedicated anti-corruption commission (Transparency International, 2004, p.60). Table 5 shows the efforts that each government has made to tackle corruption since independence in 1960.

\begin{tabular}{|l|l|l|}
\hline DATE & LEADER & $\begin{array}{l}\text { SOME NOTABLE GOVERNMENT EFFORTS TO FIGHT } \\
\text { CORRUPTION }\end{array}$ \\
\hline $\begin{array}{l}1960- \\
1966\end{array}$ & $\begin{array}{l}\text { Tafawa } \\
\text { Balewa }\end{array}$ & $\begin{array}{l}\text { Prior to 1966- The Criminal Code (the primary source of law } \\
\text { dealing with corruption) }\end{array}$ \\
$1966-$ & $\begin{array}{l}\text { Ironsi } \\
1966-\text { Criminal Justice (Miscellaneous provision) Decree }\end{array}$ \\
\hline 1967 & Nzeogwu & Declaration of war on the "ten-per-centers" and corrupt politicians \\
\hline $1967-$ & $\begin{array}{l}\text { Yakubu } \\
1975\end{array}$ & Gowon \\
\hline $\begin{array}{l}1975- \\
1976\end{array}$ & $\begin{array}{l}\text { Murtala } \\
\text { Mohammed }\end{array}$ & $\begin{array}{l}\text { Public Complaints Commission, 1975 - Corrupt Practices Decree, } \\
\text { massive retrenchment of civil servants for corruption, inefficiency } \\
\text { and abuse of office }\end{array}$ \\
\hline
\end{tabular}

${ }^{9}$ Source: Adamolekun (2011) 


\begin{tabular}{|c|c|c|}
\hline DATE & LEADER & $\begin{array}{l}\text { SOME NOTABLE GOVERNMENT EFFORTS TO FIGHT } \\
\text { CORRUPTION }\end{array}$ \\
\hline $\begin{array}{l}1976- \\
1979\end{array}$ & $\begin{array}{l}\text { Olusegun } \\
\text { Obasanjo }\end{array}$ & $\begin{array}{l}\text { Tribunals } \\
1976 \text { - Public Officer (Investigation of Assets) Decree no. 5. This } \\
\text { was later supplemented by the code of Conduct Bureau and Code } \\
\text { of Conduct Tribunal as spelt out in the } 1979 \text { Constitution }\end{array}$ \\
\hline $\begin{array}{l}1979- \\
1983\end{array}$ & Shehu Shagari & Ethical Revolution \\
\hline $\begin{array}{l}1983- \\
1985\end{array}$ & $\begin{array}{l}\text { Mohammadu } \\
\text { Buhari }\end{array}$ & $\begin{array}{l}\text { WAI Brigade, "Witch Hunts" - Tribunals and Probes - War Against } \\
\text { Indiscipline } 1984 \text { - The Recovery of Public Property Act }\end{array}$ \\
\hline $\begin{array}{l}1985- \\
1993\end{array}$ & $\begin{array}{l}\text { Ibrahim } \\
\text { Babangida }\end{array}$ & $\begin{array}{l}\text { Use of Directorate of Military Intelligence, MAMSER, WAI, Code } \\
\text { of Conduct Tribunal, "Witch Hunts" - Tribunals 1989- Decree } \\
\text { 1,The code of Conduct Bureau with a Tribunal amended as Cap.56, } \\
\text { Laws of the Federal Republic of Nigeria, 1990;National Committee } \\
\text { on Corruption and other Economic Crimes (NCCEC) }\end{array}$ \\
\hline $\begin{array}{l}1993- \\
1993\end{array}$ & $\begin{array}{l}\text { Ernest } \\
\text { Shonekan }\end{array}$ & \\
\hline $\begin{array}{l}1993- \\
1998\end{array}$ & Sani Abacha & $\begin{array}{l}\text { Directorate of Military Intelligence - War Against Indiscipline \& } \\
\text { Corruption - Failed Banks Tribunal - Witch hunts, Terror, } \\
\text { Advance Fee Fraud (popular called ' } 419^{\prime} \text { ) and Fraud Related } \\
\text { Offences Act of } 1995\end{array}$ \\
\hline $\begin{array}{l}1998- \\
1999\end{array}$ & $\begin{array}{l}\text { Abdulsalami } \\
\text { Abubakar }\end{array}$ & \\
\hline $\begin{array}{l}1999- \\
2007\end{array}$ & $\begin{array}{l}\text { Olusegun } \\
\text { Obasanjo }\end{array}$ & $\begin{array}{l}\text { Code of Conduct Bureau (CCB) and Code of Conduct Tribunal } \\
\text { updated as c.15, Laws of the Federal Republic of Nigeria, 2004; } \\
\text { ICPC, EFCC, "Due Process", Budget Monitoring and Price } \\
\text { Intelligence Unit giving rise to a Public Procurement Bill, Fiscal } \\
\text { Responsibility Bill, anti-money laundering Act, Selective Recovery } \\
\text { of Looted Funds, Panels of inquiry, e.g. Kolade Panel, } \\
\text { Package of Public Sector Reforms - Bureau for Public Sector } \\
\text { Reforms, Process of Consolidation in the Financial Services } \\
\text { Industry. Enforcement of 'Know Your Customer' rules in banks, } \\
\text { Pensions Reforms, Debt Forgiveness; Nigeria Extractive Industries } \\
\text { Transparency Initiative }\end{array}$ \\
\hline $\begin{array}{l}2007 \quad- \\
2010\end{array}$ & $\begin{array}{l}\text { Umaru Musa } \\
\text { Yar'adua }\end{array}$ & $\begin{array}{l}\text { Bureau for Public Procurement, Further reforms of the } \\
\text { consolidated banking industry, Considerations on whether to } \\
\text { merge ICPC, EFCC and CCB; re-examination of their mandates, the } \\
\text { easing out of Mr. Ribadu from his position as Chairman, EFCC. }\end{array}$ \\
\hline $\begin{array}{l}2010- \\
\text { date }\end{array}$ & $\begin{array}{l}\text { Goodluck } \\
\text { Jonathan }\end{array}$ & A continuation of the Yar'adua administration \\
\hline
\end{tabular}

Table 3: Summary of Government Efforts at Fighting Corruption, 1960-200910

${ }^{10}$ Source: Convention on Business Integrity (2010), p.9 
While there are many definitions of corruption in the literature (RoseAckerman, 2006; Johnston, 2005; Ikubaje, 2006), I will simply be adopting the Transparency International definition of corruption for the purposes of this study. Transparency International's Corruption Perception Index (CPI) is reputed to be "the world's most credible measure of domestic public sector corruption (The Guardian, 2010)". Such credibility would have had to have drawn on a definition of corruption that is globally understood and used. It is for this reason that I have preferred the definition of corruption that underpins the CPI to any other definition in the literature.

Transparency International defines corruption as "the abuse of entrusted power for private gain" (Transparency International, undated). This definition is equally applicable to the private sector as it is to the public sector. Therefore a managing director of a bank that illegally diverts depositor funds to his private use is as guilty of corruption as the minister of public services that enriches herself from the public treasury. Nigeria's score on the CPI from 1996 to 2010 is shown in Table 4.

\begin{tabular}{|c|c|c|c|}
\hline Year & CPI Score & Nigeria's CPI Ranking & Remarks \\
\hline 1996 & 0.69 & $54 / 54$ & Most corrupt \\
\hline 1997 & 1.78 & $52 / 52$ & Most corrupt \\
\hline 1998 & 1.9 & $81 / 85$ & $2^{\text {nd }}$ most corrupt \\
\hline 1999 & 1.6 & $98 / 99$ & $2^{\text {nd }}$ most corrupt \\
\hline 2000 & 1.2 & $90 / 90$ & Most corrupt \\
\hline 2001 & 1.0 & $90 / 91$ & $2^{\text {nd }}$ most corrupt \\
\hline 2002 & 1.6 & $101 / 102$ & $2^{\text {nd }}$ most corrupt \\
\hline 2003 & 1.4 & $132 / 133$ & $2^{\text {nd }}$ most corrupt \\
\hline 2004 & 1.6 & $144 / 146$ & $2^{\text {nd }}$ most corrupt \\
\hline 2005 & 1.9 & $152 / 159$ & $3^{\text {rd }}$ most corrupt \\
\hline 2006 & 2.2 & $142 / 163$ & $5^{\text {th }}$ most corrupt \\
\hline 2007 & 2.2 & $147 / 180$ & $9^{\text {th }}$ most corrupt \\
\hline $\mathbf{2 0 0 8}$ & $\mathbf{2 . 7}$ & $\mathbf{1 2 1 / 1 8 0}$ & $\mathbf{5 9}^{\text {th }}$ most corrupt \\
\hline 2009 & 2.5 & $130 / 180$ & $50^{\text {th }}$ most corrupt \\
\hline 2010 & 2.4 & $134 / 178$ & $42^{\text {nd }}$ most corrupt \\
\hline
\end{tabular}

Table 4: Nigeria's Score on the Corruption Perception Index, 1996-2010 (Adamolekun, 2011). 
Having been either the most corrupt or second most corrupt country in the world for the first 9 years, Nigeria starts to show steady improvement since 2005, owing largely to the contributions of ICPC and EFCC. Each year, the CPI measures perception over the preceding three years. Therefore, anticorruption efforts made one year will take about three years to affect the perceptions in CPI (Internet Centre for Corruption Research, Undated). The most dramatic improvement was in 2008 but this was not sustained in 2009 and, although the trend worsened in 2010, Nigeria's scores were still better than it ever was before 2007.

I will now seek to understand ICPC and EFCC and how they work. Both organisations are similar in their remit but EFCC is outperforming ICPC. A comparative analysis of both organisations will reveal the reasons for this differential performance.

\subsection{The Independent Corrupt Practices and Other Related Offences Commission (ICPC)}

\subsubsection{Brief History of ICPC}

The bill for an Act to prohibit and prescribe punishment for corruption, and establish the ICPC, was the first bill that former President Obasanjo sent to the national assembly on Nigeria's return to democratic rule in 1999 (Momoh, 2010, p.5). The Corrupt Practices and Other Related Offences Act 2000 (CPA 2000), was eventually enacted in September, 2000, after months of debate during which the National Assembly had protested that 7 years imprisonment was too harsh a punishment for official corruption. The ICPC was inaugurated on 29 September 2000, with Justice Mustapha Akanbi (a retired Justice of the Court of Appeal) as its pioneer Chairman.

The ICPC has twelve members, known as Commissioners, and membership of the commission is drawn from the six geo-political zones of Nigeria with each zone producing two members. Section 3 of the CPA 2000 prescribes how the commission should be constituted. Its membership should comprise: 
- a retired police office not below the rank of a Commissioner of Police;

- a legal practitioner with at least 10 years post-call experience;

- a retired Judge of a superior court of record;

- a retired public servant not below the rank of a Director;

- a woman;

- a young person not less than 21 or more than 30 years at the time of his or her appointment; and

- a chartered accountant.

To get the organisation off the ground, public servants were seconded from other existing government organisations such as the Nigerian Police Force and the Federal Ministry of Justice. Three months after its inauguration, the commission had received 44 petitions about corrupt practices in public life. By 2001, the number of petitions had risen to 336.

In 2002, the ICPC received allegations of corruption against the President of the Senate, the Speaker of the House of Representatives and 84 members of the National Assembly. As the ICPC commenced investigations, both houses of the National Assembly accused the commission of hounding its members and being a political tool in the hands of President Obasanjo. The National Assembly attempted to repeal and re-enact the CPA 2000, with much weaker powers. The move was vigorously resisted by the Commission, civil society and even some members of the same National Assembly. Despite massive opposition, the National Assembly was determined to pass the watered-down bill, even if it meant overriding presidential veto. However, before the bill was passed, some progressive members of the House of Representatives obtained a court injunction stopping the passage of the bill. In 2003, the Federal High Court finally nullified the purported repeal of CPA 2000 and declared that the attempted re-enactment was null and void (Transparency International, 2004, p.62).

Since inception, the Commission has had two chairmen, each completing a five-year term as prescribed by the Act. The last chairman finished his tenure late in 2010 and the President of Nigeria forwarded the name of a retired Supreme Court Judge to the Senate for screening, preparatory to his appointment as the third chairman of ICPC. However, the nomination was rejected by the Senate on the grounds that the nominee was too old and did 
not have a clear view about what he wanted to achieve in the Commission. I will return to this issue later in this chapter when I discuss the issues of pressure, demand and leadership, since the rejection of that nomination was largely engineered by civil society organisations.

One of the Commissioners in ICPC, Professor Angulu, an academic, was made Acting Chairman pending when the President would produce a fresh nominee or resubmit the same earlier nomination. However, the Acting Chairman was unceremoniously removed one month later and no reasons were given by government for his removal. At the time of Professor Angulu's removal, I was undertaking fieldwork on ICPC and the suspicion of most people inside and outside the organisation at the time was that he was removed because of his insistence on prosecuting certain high-level corruption cases allegedly involving a Minister of State in the government and the Chief Justice of Nigeria.

Following Professor Angulu's removal in March 2011, another Commissioner, a retired Assistant Inspector General of Police, was appointed to act as Chairman. Nothing has been heard since then about the investigations concerning the Minister of State and the Chief Justice of Nigeria. Again, I will return to this issue later in this chapter when I discuss the issues of leadership.

As at March 2011, ICPC had filed 255 cases in court, since inception, from which it had obtained 35 convictions.

\subsubsection{Functions of ICPC}

Section 6 of CPA 2000 sets out the general duties of the Commission as:

(a) To receive and investigate any report of the conspiracy to commit, attempt to commit or actual commission of offences under the Act or any other law prohibiting corruption;

(b) To examine the practices, systems and procedures of public bodies and where, in the opinion of the Commission, such practices, 
systems or procedures aid or facilitate fraud or corruption, to direct and supervise a review of them;

(c) To instruct, advise and assist any officer, agency or parastatal on ways by which fraud or corruption may be eliminated or minimised by such officer, agency or parastatal;

(d) To advise heads of public bodies about practices, systems or procedures to reduce the likelihood or incidence of bribery, corruption, and related offences;

(e) To educate the public on and against bribery, corruption and related offences; and

(f) To enlist and foster public support in combating corruption.

The Act enumerates 19 different offences mainly concerning fraud, bribery, gratification and fraudulent acquisition of property. Most offences carry a 7year jail term, with the lightest punishment being 1-year imprisonment or N50,000 fine (about \$300) for transferring money from one budget head to another without approval. The heaviest punishment under the Act is 10 years' imprisonment for wilfully sending false petitions to the Commission.

\subsubsection{Mode of Operation}

Apart from the Office of the Chairman and that of the Secretary to the Commission, ICPC is structured into seven departments:

1. Investigation

2. Prosecution

3. Special Duties

4. Public Enlightenment

5. Education

6. Finance and Administration

7. Planning, Research and Review

CPA 2000 contains certain special features that distinguish it from previous criminal laws. Particularly, Section 53 of the Act shifts the burden of proof of innocence from the prosecution to the accused for cases of fraud, bribery, gratification and fraudulent acquisition of property. Therefore, where a 
person is accused of receiving a bribe, for instance, the accused will have the onus of proving their own innocence, rather than the prosecution having to prove their guilt. In criminal cases, the burden of proof is normally on the prosecution to prove the charge beyond reasonable doubt. This is the case in the rest of Nigerian law and that of most of the Commonwealth (Aguda, 1974, p.189).

Also, under Section 60 of the Act, evidence is not admissible to the effect that offering and/or accepting gratification is customary or traditional in any profession, trade, vocation or calling or on a social occasion. This eschews the need for a debate as to whether or not certain so-called cultural expectations, like public servants expecting tips for carrying out their normal functions, amounts to corruption. Under the Act, culture is no defence. This provision of Section 60, CPA 2000, is also a departure from the normal provisions of the Evidence Act in Nigeria which allows evidence of culture and tradition (Aguda, 1974, p. 94).

According to Section 27 of CPA 2000, the ICPC can only investigate information or petitions that it receives in writing. Where the information or petition is made orally, it should be reduced into writing and endorsed by the petitioner before the ICPC can investigate it. This has been interpreted by the ICPC to mean that it cannot proactively initiate investigations and has to wait until it receives a written petition. Therefore, even where there are grounds to believe that a breach of the Act has occurred, the ICPC will do nothing until a petition is received. If no petition is received, it will not look into the matter. The Commission has proposed an amendment of CPA 2000 to give it explicit powers to initiate investigations but that proposal has been pending since 2003, as the Commission appears not to have had the willingness or means to engage with the National Assembly to get the amendment through.

CPA 2000, although extensive in its remit and powers, did not explicitly cover financial crimes such as bank fraud, money laundering and obtainingby-false-pretences. It focused almost entirely on public sector corruption. The Act cannot also be applied retroactively and only covers crimes committed since the Act was enacted. 
ICPC relies mostly on the police and the Office of the Director of Public Prosecutions in the Federal Ministry of Justice to prosecute its cases. This often means the decision whether or not to prosecute is first and foremost that of the Director of Public Prosecutions, who may direct the commencement of prosecution or that the case should be dropped. ICPC cases also form a part of the normal caseloads of public prosecutors and the courts and do not receive any special treatment. ICPC cases are subject to interlocutory injunctions and applications for stays of execution which can be used by defence lawyers to frustrate trials.

ICPC has a staff strength of 530, as at March 2011, and, apart from the initial secondments at the start of the organisation, recruitment is done openly through advertisements and a transparent selection process.

Having briefly outlined the history and nature of ICPC, I will now set out the history and nature of a similar organisation, EFCC, before undertaking a comparative analysis of both organisations against research propositions.

\subsection{The Economic and Financial Crimes Commission (EFCC)}

\subsubsection{Brief History of EFCC}

In 2001, Nigeria was added to the Financial Action Task Force's (FATF's) blacklist of 'Non Cooperating Countries or Territories' (NCCTs). The FATF is made up of 34 countries and territories and two regional organisations, and their list of non cooperative countries and territories includes those countries and territories that are perceived to be non-cooperative in the global fight against money laundering and terrorist financing. The FATF's Forty Recommendations requires states to, inter alia, implement relevant international conventions, criminalise money laundering and enable authorities to confiscate the proceeds of money laundering, implement customer identity verification and due diligence, keep records of suspicious financial transactions, establish a financial intelligence unit and cooperate internationally in investigating and prosecuting money laundering. 
The government of Nigeria understood the fact that inclusion on this list meant reduced foreign investment, international restrictions on Nigerian business and harassment of Nigerian travellers by immigration officials in foreign countries. It felt that what was needed to get off the blacklist was beyond the scope and abilities of ICPC and set up a Special Committee on Financial Crimes, headed by the Attorney General of the Federation. The mandate of the committee was to draft a bill setting up a commission to combat financial crimes and respond to the FATF. It was considered a matter of urgent national importance to get off the FATF list and get into the good books of the major international finance bodies. ${ }^{11}$

The law to set up the EFCC was first proposed in 2002 as the Economic and Financial Crimes Commission (Establishment) Act 2002. However, the Commission did not commence operations until April 2003 when its pioneer Chairman, Nuhu Ribadu, was appointed. The 2002 Act was repealed in 2004 when The Economic and Financial Crimes Commission (Establishment) Act was enacted. Significantly, in addition to enforcing the provisions of its own laws, EFCC is empowered to enforce the provisions of other laws dealing with economic and financial crimes, including those that were in place before its creation. These include:

- The Banks and other Financial Institutions Act, 1991;

- The Failed Banks (Recovery of Debts) and Financial Malpractices in Banks Act, 1994;

- The Money Laundering Act, 1995;

- The Miscellaneous Offences Act, 2004 (Federal Government of Nigeria, 2004a).

- The Money Laundering (Prohibition) Act, 2004 (Federal Government of Nigeria, 2004b); and

- The Advance Fee Fraud and Other Fraud Related Offences Act, 2006.

The Chairman has to be a serving or retired member of any government security or law enforcement agency not below the rank of Assistant

\footnotetext{
${ }^{11}$ My interview with Ibrahim Lamorde, pioneer Director of Operations, EFCC, on 22 December, 2010.
} 
Commissioner of Police or equivalent, with not less than 15 years experience.

Membership of the Commission is very wide. Although only the Chairman and Secretary are permanent members, membership includes the Governor of the Central Bank, representatives from the Federal Ministries of Foreign Affairs, Finance, and Justice, the Chairman of the National Drug Law Enforcement Agency, the Director-General of the National Intelligence Agency, the Director-General of the State Security Service, the Comptrollers General of Customs and Immigration, and the Inspector General of Police. Therefore, the EFCC was set up both as an anti-corruption agency and a counter terrorism body. To get the organisation off the ground, personnel were seconded principally from the Police, State Security Service and other national security organisations.

Since inception, EFCC has had two substantive chairmen. The Act prescribes a 4-year tenure for the Chairman, renewable for a further 4-year term and no more. The pioneer Chairman, Nuhu Ribadu was removed in 2008 following the change of government in Nigeria in 2007. At first, the Inspector General of Police announced that Ribadu was to proceed on a training course to prepare him for higher office, possibly as a future Inspector General of Police. However, while attending the course, he was twice demoted and removed from his post at EFCC. Attempts were made on his life and he was forced to flee the country to save his life.

Ribadu's powerful Director of Operations, Ibrahim Lamorde, was initially made Acting Chairman, but, within a few months, he too was posted out of the EFCC into a non-descript job in a police station outside the federal capital. Eventually, a retired Assistant Inspector General of Police, Farida Waziri, was appointed Chairman of EFCC. At her screening in the Senate, she was forced to deny allegations that she been sponsored for the post by some corrupt individuals that she had shielded from prosecution when she worked as a policewoman. Many development agencies withdrew their support for EFCC in protest about the way that Ribadu had been treated and accused the government of sabotaging the war against corruption.

President Umar Musa Yar'adua, under whose watch the events described above occurred died early in 2010 and was succeeded by his Vice President, 
Goodluck Jonathan. Under this new dispensation, Ribadu felt able to return to Nigeria and subsequently launched a campaign to become President. He lost the elections in April 2011 and subsequently took up an international anti-corruption position in Afghanistan. In December, 2010, his erstwhile Director of Operations, Ibrahim Lamorde was suddenly redeployed to EFCC by the President, allegedly, without the courtesy of informing the Chairman, Mrs Waziri, in advance (Unnamed source in EFCC, 2010). He succeeded Mrs Waziri as Chairman, following her sack in November, 2011.

I will return to the issues of the effect of changes in leadership at the organisational level and changes in leadership at the political level later in this chapter.

\subsubsection{Functions of EFCC}

The functions of the EFCC as defined in the Economic and Financial Crimes Commission (Establishment Act, 2004), (Federal Government of Nigeria, 2004) are as follows;

(a) The enforcement and the due administration of the provisions of the Act;

(b) The investigation of all financial crimes including advance fee fraud, money laundering, counterfeiting, illegal charge transfers, futures market fraud, fraudulent encashment of negotiable instruments, computer credit card fraud, contract scam, etc.;

(c) The co-ordination and enforcement of all economic and financial crimes laws and enforcement functions conferred on any other person or authority;

(d) The adoption of measures to identify, trace, freeze, confiscate or seize proceeds derived from terrorist activities, economic and financial crime related offences or the properties the value of which corresponds to such proceeds;

(e) The adoption of measures to eradicate the commission of economic and financial crimes;

(f) The adoption of measures which include coordinated preventative and regulatory actions, introduction and maintenance of 
investigative and control techniques on the prevention of economic and financial related crimes;

(g) The facilitation of rapid exchange of scientific and technical information and the conduct of joint operations geared towards the eradication of economic and financial crimes;

(h) The examination and investigation of all reported cases of economic and financial crimes with a view to identifying individuals, corporate bodies or groups involved;

(i) The determination of the extent of financial loss and such other losses by government, private individuals or organizations;

(j) Collaborating with government bodies both within and outside Nigeria carrying on functions wholly or in part analogous with those of the commission;

(k) Dealing with matters connected with the extradition, deportation and mutual legal or other assistance between Nigeria and any other country involving economic and financial crimes;

(1) The collection of all reports relating to suspicious financial transactions analyse and disseminate to all relevant government agencies;

(m) Taking charge of supervising, controlling, coordinating all the responsibilities, functions and activities relating to the current investigation and prosecution of all offences connected with or relating to economic and financial crimes;

(n) The co-ordination of all existing, economic and financial crimes instigating units in Nigeria;

(o) Maintain a liaison with the office of the Attorney-General of the Federation, the Nigerian Customs Service, the Central Bank of Nigeria, the National Drug Law Enforcement Agency, among others;

(p) Carrying out and sustaining rigorous public enlightenment campaign against economic and financial crimes within and outside Nigeria; and

(q) Carrying out such other activities as are necessary or expedient for the full discharge of all or any of the functions conferred on it under this act. 


\subsubsection{Mode of Operation}

The commission is divided into the following units;

1. The Operations Unit;

2. The General And Assets Investigation Unit;

3. The Legal And Prosecution Unit;

4. The Research And Training Unit; and

5. The Administration Unit.

Part IV of the EFCC Act 2004 sets out the offences under the Act. Apart from offences relating to financial crimes and the supply of false information, the Act prescribes penalties for offences relating to terrorism. Most offences are punishable with 5 years imprisonment or a fine, with stiffer punishment reserved for public officials. For instance, the maximum punishment for giving false information to the Commission is 3 years, but where the offender is a public officer, the punishment for the same offence can go up to 5 years. The heaviest punishment under the Act is for terrorism which carries a punishment of life imprisonment. The Act also allows the Commission to seize property suspected to be proceeds of crime, pending trial by the courts. Where an accused person is convicted under the Act, all such seized property shown to be derived from illegal activity under the Act is forfeited to the Federal Government.

Section 7 of the Act empowers the Commission to initiate investigations into any matters under the Act. Unlike ICPC, it does not need to wait for a written petition to be submitted to it before it can commence investigations.

The administration of justice in Nigeria is very slow, with many criminal cases lasting 10 years or more in the courts. Some of the cases instituted by ICPC in its first year of operation in 2000 are still in court today. This is often because of innumerable ex-parte orders and interlocutory injunctions filed by defence lawyers to frustrate the prosecution of their clients. Most unusually, Section 40 of EFCC Act 2004 says that an application for stay of proceedings in any criminal matter brought by the Commission before the court shall not be entertained. This provision means that, compared to other 
criminal matters such as ICPC offences, EFCC cases can be speedily disposed-of by the courts.

Because the EFCC Act 2004 empowers the Commission to enforce provisions of various Acts that existed before it was set up, it can prosecute crimes committed before the existence of the Commission. For instance, the Advance Fee Fraud and Other Fraud Related Offences Act was enacted in 1995 and the Banks and other Financial Institutions Act was enacted in 1991. This is different from ICPC that cannot prosecute offences committed before its creation.

EFCC Act 2004 empowers the Commission to conduct its own investigations without relying on officers of the Nigerian Police Force. It also carries out its own prosecutions in court, without depending on the Director of Public Prosecutions in the Federal Ministry of Justice. The ICPC, on the other hand, has to wait for directions from the Director of Public Prosecutions as to whether or not a case should be prosecuted or dropped.

EFCC has a staff strength of 1600 in its headquarters and 5 offices across the country. Most of its pioneer officers were hand-picked people with a record of integrity, drawn mostly from the police and the intelligence organisations such as the State Security Service. EFCC has since started to advertise its vacancies.

\subsection{Application of Dependent Variable}

Performance is the dependent variable in this research. I had explained in Chapter 1 that, although performance could be assessed through the lenses of inputs, outputs, outcomes and even impacts, I will be focusing on outputs in this research. I will therefore be measuring performance by assessing the extent to which each organisation studied here has achieved its pre-determined goals with regards to its outputs, given a certain level of inputs.

Measuring the performance of anti-corruption agencies is a difficult endeavour. It is usual to assess the performance of a country's anti- 
corruption agency using data from corruption surveys and cross-country and international rankings such as the one published by Transparency International. However, there is always a problem with attribution and it is often difficult to draw causal links between the work of anti-corruption agencies and these macro-level outcomes (USAID, 2006a, p. 14). The task is even more difficult in our present case where we have two anti-corruption agencies that perform very similar functions in the same country.

When measuring the achievement of outputs by anti-corruption agencies therefore, two performance indicators are common in the literature:

a. Prosecution to conviction rates, i.e., how many cases prosecuted lead to the conviction of the accused person? (USAID, 2006a, p.14; Johnson, et al., 2011, p.62; Meagher, 2002, p.85); and

b. Asset recovery rates, i.e. how successful was the agency in recovering stolen assets or assets acquired through the proceeds of corruption? (Bolongaita, 2010, p. 17; Johnson, et al., 2011, p.63)

I will be using these two performance indicators to assess the performance of EFCC and ICPC, and Table 3 below shows how both organisations have performed against the two indicators as at March 2012. It is worth noting that while EFCC freely discloses its performance on prosecution to conviction ratios and asset recovery on its website and in publications, the performance data on ICPC was tortuously difficult to get. I initially obtained the performance figures of ICPC through a source within the ICPC who asked not to be named and this was in the form of an internal memorandum. However, I subsequently put the figures to the Secretary of the ICPC in my interview with him on 16 March 2011 and he confirmed them to be correct. It is possible that ICPC may have secured more convictions and recovered more money since 16 March, 2011, but I was not able to verify this at the time of writing in March 2012. 


\begin{tabular}{|l|l|l|}
\hline Organisation & Prosecution to conviction rates & Money Recovered \\
\hline EFCC & $\begin{array}{l}700 \text { prosecutions and 500 convictions } \\
(\text { Punch, 2012) }(71 \% \text { success rate })\end{array}$ & $\begin{array}{l}\$ 11 \text { billion (Vanguard, } \\
2010)\end{array}$ \\
\hline ICPC & $\begin{array}{l}255 \text { prosecutions and 35 convictions }{ }^{12}(14 \% \\
\text { success rate) }\end{array}$ & $\$ 100$ million $^{13}$ \\
\hline
\end{tabular}

Table 5: ICPC/EFCC Performance

\subsection{Application of Explanatory Variables}

In Chapter 1, the explanatory variables related to my research question are set out as various internal and external factors. I will now examine these variables in the context of EFCC and ICPC to see how they apply to the dependent variable in my research question.

\subsubsection{Internal Factors}

Internal factors are those factors, often within the organisation's direct control, such as the way it is led, organised and managed, issues of pay and staff motivation, ability to secure sufficient budgetary provisions, and the use of technology. This is to be distinguished from external factors such as political economy or institutions over which the organisation has little or no control.

\section{Leadership}

Section 3(4) of CPA 2000 states that the Chairman of ICPC shall be a person who has held, or is qualified to hold, office as a judge of a superior court of record in Nigeria. The effect of this is that the ICPC can only be led by a lawyer with at least 10 years experience, since that is the minimum qualification to be a judge of a superior court of record (i.e., High Courts, Courts of Appeal and Supreme Court). The first chairman of ICPC was a retired President of the Court of Appeal and the second was a retired Justice

\footnotetext{
${ }^{12}$ Elvis Oglafa, Secretary to ICPC, interview with me on 16 March 2011.

${ }^{13}$ Elvis Oglafa, Secretary to ICPC, interview with me on 16 March 2011.
} 
of the Supreme Court. As the retirement age for judicial officers in Nigeria is 70 years, both Chairmen were in their 70 's when they were appointed.

When the tenure of the second chairman expired in September 2010, Nigeria's President nominated another retired Supreme Court judge to the Senate for confirmation as the new chairman of ICPC. However, several civil society organisations that focus on anti-corruption wrote to the Senate urging it to reject the nomination, on the basis that his appointment will "have a counterproductive effect on an already docile anti-corruption agency"(Daily Trust 2011a). The Senate rejected the nomination on the grounds that the nominee was too old to lead the organisation with vigour and did not display sufficient understanding of what ICPC stood for (Vanguard, 2011). The Senate Committee on Drugs, Narcotics, Financial Crimes and Anti-corruption in its report said:

ICPC is in dire need of focus, repositioning and effectiveness. The committee believes that a person over the age of 70 will be unable to perform this task optimally [...] Even though the ICPC is four years older than the EFCC, the Committee believes the reason why the ICPC, unlike EFCC, has not done much in terms of establishment of its infrastructure and the effectiveness of its operations, is simply because the two previous chairmen were too old to cope with the tasking and demanding rigours of the position (Nigerian Tribune, 2011).

An interesting dimension to the Senate rejection is that it was engineered by a coalition of civil society groups who made written representations to the committee asking it to reject the nomination and give ICPC a new lease of life. This is interesting for my discussion of pressures and demand later on in this chapter.

Following the Senate rejection of the nomination, one of the Commissioners in ICPC, an academic, was designated Acting Chairman. Probably with an eye on the permanent chairmanship position, the Acting Chairman, Professor Angulu, set about pursuing some high profile corruption cases 
with vigour. He was removed from his post after just one month, allegedly because the government seemed to be "uncomfortable with the recent combative anti-corruption drive of ICPC."(Sahara Reporters, 2011a). Although no official reason was given for his removal, I was carrying out field work in ICPC at the time of the Acting Chairman's removal and the feeling of people within and outside the commission was that he was removed because the government tried unsuccessfully to dissuade him from investigation allegations of corruption against the Chief Justice of Nigeria, and prosecuting another serving Minister. A few days after Professor Angulu's removal, the Attorney General of the Federation stopped the trial of the Minister, after ICPC had prepared to arraign him on corruption charges.(Sahara Reporters 2011)

Following Professor Angulu's removal, another ICPC Commissioner, Dr. Rosemary Abang-Wushishi, was made Acting Chairman. One internet news site quoted a source in ICPC as saying that new Acting Chairman was an "inept, physically and mentally tired woman, who resumes work around 2pm in the afternoon" (Sahara Reporters, 2011b). Nothing further has been heard about the allegations against the Chief Justice and the Minister since Professor Angulu was relieved of his post. On 1 June, 2011, the President sent a letter to the Senate nominating a fresh candidate, a practicing lawyer rather than a retired judge, as the new Chairman of ICPC. As at July, 2011, the nominee had not yet been screened by the Senate. (This Day, 2011d)

The weak performance of ICPC has also been blamed on its leadership by retired senior judges for an altogether different reason. It is arguable that a retired Supreme Court will naturally want to meticulously ensure that a case is watertight before allowing it to go to trial, rather than place the onus on the accused persons to defend themselves, as stipulated by CPA 2000. In describing the difference between ICPC and EFCC in this regard, the ICPC Head of Investigations said of ICPC, "Leadership wants to interpret, rather than enforce" ${ }^{14}$ It is worth noting that the ICPC Head of Investigation was seconded from the Nigeria Police Force in 2009 to boost prosecution rates, and is a serving policeman, rather than a lawyer.

\footnotetext{
${ }^{14}$ My interview with Mr Sotonye Leroy Wakama, Head of Department, Investigation, ICPC on 21 March, 2011.
} 
In a focus group discussion with ICPC officers on 8 August, 2011, one set of discussants attributed the weak performance of ICPC to the inability of organisational leadership to take responsibility for actions, among other things. They explained that while out in the field investigating cases of corruption, officers could not always be certain that they had the backing of the leadership. Therefore, if the investigation goes well, the leadership is enthusiastic and takes the credit. If, however, anything goes wrong during the investigation, the agent is on his own. This causes a certain hesitancy and tentativeness which constraints performance.

A newspaper article reviewing the performance of ICPC after 11 years said:

The Chairman of ICPC must be a man or woman with the anti-corruption track record. S/he cannot be appointed on the basis of promotion from board member to chairman or on the basis of patronage or having retired as a Judge. We need energy, passion and vision; which is what Ribadu brought to the EFCC job; what Akunyili brought to the NAFDAC job; what el-Rufai brought to the Abuja job. Energy, passion, vision (This Day, 2011e).

Nuhu Ribadu was a 43 year-old Assistant Commissioner of Police when he started the EFCC in 2003. When the EFCC Act was being drafted, the initial proposal was that the Commission should be headed by an Assistant Inspector General of Police, serving or retired. The rank of Assistant Inspector General in the Nigerian Police Force is three steps higher than that of Assistant Commissioner of Police. However, when the Attorney General of the Federation tried to find an upright current or retired Assistant Inspector General, his search was said to have been fruitless. Ribadu fitted the character of an upright and fearless policeman, but was of junior rank. The Attorney General had to lower the qualification for heading the commission to Assistant Commissioner of Police to accommodate Ribadu (Adebanwi, 2010, pp. 26-27).

In my interview with Ribadu, his proposition was that leadership is the driving force that can make a difference where things don't work. He 
enumerated the key ingredients for achieving atypical performance in difficult environments thus:

You need to get a leader that can capture the vision and mission, knows the area and can navigate the processes properly, who understands the terrain and environment properly - is daring and courageous. Understanding the subject is so central, as is having a very clear vision. Knowing what you want to achieve. Know the subject. Have the skills. Have the ability to attract people of like minds. An inspirational leader captures the vision on behalf of all. Before I went to EFCC, I knew why law enforcement failed in this country. Even before I had one penny to run the place, I knew what was needed. I was not going to take money and nobody working with me was going to take money. My prior knowledge and understanding of the subject was key. Leadership is the driving thing that can make the difference in a system where things don't work well. ${ }^{15}$

When pressed about the importance of the political support that he received as EFCC Chairman, he was of the opinion that he would have succeeded without the President's support. He even felt that in the absence of budgetary provision, he would have obtained resources somehow to run the organisation. In buttressing his claimed ability to do the seemingly impossible, he informed that me that he would become President of Nigeria even though he had no money of his own with which to fund his election campaign. In talking about the success of EFCC, he reiterated the importance of leadership thus: "You see, the individual makes a difference especially where there is no system. At the risk of sounding immodest, none of it would have happened without me."16

\footnotetext{
${ }^{15}$ My interview with Nuhu Ribadu, pioneer Chairman of EFCC, on 7 December, 2010.

${ }^{16}$ My interview with Nuhu Ribadu, pioneer Chairman of EFCC, on 7 December, 2010.
} 
Nuhu Ribadu ran for the office of President of Nigeria in the April 2011 elections, with the campaign slogan "Nigeria deserves better leadership". He lost.

It is worth noting the unshakable optimism of the man, his belief that the individual can overcome the system and the seeming immodesty to have attributed all of EFCC's success to himself. I will return to this point in other case studies when I look at the characteristics of the leaders of other atypical organisations.

The change of government in Nigeria and the emergence of a new President in 2007 had a dramatic impact on the leadership of EFCC. The new President appeared to show no interest in fighting high-profile corruption and appointed a team that seemed to share the same view, including the Attorney General and the Inspector General of Police (Ribadu, 2010, p.83). The Attorney General attempted to take over the prosecutorial powers of both EFCC and ICPC and centralise it in his office. This would have meant that he could simply refuse to prosecute cases of corruption that had been investigated by both organisations. However, legal precedents and the laws setting up both commissions prevented him from being able to do so. The Attorney General allegedly bluntly told Ribadu during their first meeting that the President had mandated him to stop prosecuting corrupt state governors (Ribadu, 2010, p.83). When Ribadu refused, he was first sent as a participant on a course on which he had been a lecturer for several years, then demoted by two ranks and was eventually dismissed from the Nigerian Police Force. Two attempts were also made on his life, prompting him to escape from Nigeria into exile in the United Kingdom and the United States (Ribadu, 2010, p. 83). Most of Ribadu's key officers, like his respected Director of Operations, were deployed out of EFCC.

The appointment of his successor, Farida Waziri, a retired Assistant Inspector General of Police, was not warmly received. The press and some members of the Senate accused her of having shielded corrupt politicians in the past, claiming that she was "a pliable candidate, a willing tool in their campaign to sabotage the EFCC and free the governors from serious prosecution" (Sahara Reporters, 2008). Although the diplomatic community had initially pledged their continued support to EFCC, they soon became disillusioned with the new seeming lack of commitment in the efforts to 
fight corruption. The United States Government, which had staunchly supported EFCC and trained many of its staff, withdrew support for the EFCC and cut off all communications with the leadership of the Commission (Next, 2011).

Waziri's leadership style could be said to be more introverted than Ribadu's. EFCC under Waziri appears to be less controversial than it was under Ribadu. Ribadu himself admitted that he had been accused of being a cowboy, using commando-style raids and seeking the limelight. Even President Obasanjo who appointed him objected angrily to his methods. $\mathrm{He}$ justified his use of a big bang approach with the psychological impact that high profile operations can have on the psyche of the public (Ribadu, 2010, p.132). Waziri's EFCC does not appear to push the law to the limit in the same way. Instead, the EFCC claims to have "become a responsible, apolitical and lawful anti-crime agency, which carries out its functions within the ambits of the law" (Obasi, 2010).

In my opinion though, Waziri's EFCC spends an inordinate amount of time and newsprint claiming to have achieved more than Ribadu did (Daily Trust, 2011b). For instance, a newspaper article sympathetic to Waziri's cause points to the fact that under her leadership, Nigeria's Transparency International rating moved from $142^{\text {nd }}$ position in 2006 to $121^{\text {st }}$ in 2008 (This Day, 2011b). As Waziri was only appointed in 2008, the article completely misses the point that perceptions take a while to form and that ratings in 2008 would have been formed based on perceptions of efforts in previous years - under Ribadu.

Waziri has had some bad press and public perception about her leadership have been unfavourable. However, in output terms (prosecution to conviction rates and money recovered), EFCC has continued to perform well under her leadership. Under Waziri, the EFCC secured more than 100 convictions and recovered more than $\$ 3.5$ billion in the first two years of her leadership (EFCC, 2010). Ribadu blames his troubles with former President Yar'adua on EFCC's arrest of one James Ibori, a former governor who was alleged to have bankrolled the Presidents election with funds stolen from his state's treasury. Ibori is now being prosecuted by the EFCC and has been extradited to UK for trial. He was eventually jailed in the UK for 13 years for corruption. Other former governors and high profile politicians are also 
facing trial and many have been convicted and sent to prison during Waziri's tenure. Admittedly, these happened after the death of President Yar'adua and the coming into office of his then Vice President, Goodluck Jonathan.

While the EFCC persists as an atypical organisation, it is clear that Ribadu's leadership placed the organisation at the forefront of public consciousness and laid the foundation for the organisation's current successes. Waziri's focus on organisational strengthening and the use of proper systems and procedures will probably make the EFCC more likely to be sustainable in the long run. "The charismatic leader often does not prepare the best successor". ${ }^{17}$

\section{Management}

I have used the term Management here to refer to the totality of attributes and functions necessary to run an organisation effectively. It includes funding, recruitment processes, performance management, human resource management, reward and discipline, staff motivation, and pay and conditions of service.

\section{Funding}

From its inception, EFCC has consistently received more funding than ICPC. From 2007 when the Budget Office of the Federation put the federal budget on its website, the breakdown of budgetary receipts for both organisations is shown in Table 6:

\footnotetext{
${ }^{17}$ My interview with Jens-Peter Dyrbak, DFID Adviser, on 1 March, 2011.
} 


\begin{tabular}{|l|l|l|l|}
\hline Govt & 2008 & 2009 & 2010 \\
\hline ICPC & N3.5 billion & N2.2 billion & N1.9 billion \\
\hline EFCC & N4.1 billion & N6.2 billion & N9 billion \\
\hline
\end{tabular}

Table 6: ICPC/EFCC Funding 2008-2010 ${ }^{18}$

The Secretary to the ICPC blames the low level of budgetary provision on ICPC's refusal to lobby the National Assembly. He explained that the two previous Chairmen of the Commission had been of the view that if the government is truly committed to fighting corruption, they would provide the budgetary resources for the Commission to do its work. They also felt that if they lobbied members of the National Assembly, those members may attempt to influence the Commission's work when someone they or someone they knew is under investigation.

EFCC on the other hand cultivated a good relationship with legislators, particularly the leadership of both legislative arms and the House and Senate Committees on Anti-corruption. Ribadu had a very good relationship with 17 key members of the National Assembly who advocated for EFCC and ensured that its budgets and bills sailed through. Waziri has maintained that tradition. As an example, the Deputy Senate President was one of the people interviewed in EFCC's 2010 Our Milestone publication.

The position of ICPC on resource mobilisation is curious, given that there may be many things that a government is serious about but it cannot make adequate budgetary provisions for every one of them, to the exclusion of everything else. Every department of ICPC has blamed its limited effectiveness on a lack of adequate funding. In interviews with me, the Head of the Department of Planning Research and Review blamed lack of funding for their inability to carry out more system studies of organisations. He suggested that ICPC should be allowed to keep some of the money it recovers from convicted criminals to fund its own operations. The Head of the Department of Operations highlighted the dissatisfaction of his

\footnotetext{
${ }^{18}$ Source Budget Office of the Federation at http://www.budgetoffice.gov.ng/
} 
investigators with the number of days in the field that they can claim duty tour allowances for, as a result of a lack of funds. The Education Department similarly said that inadequate funding had restricted their ability to produce information, education and communication material. The Secretary to the Commission says that the Commission has had a change of heart about its approach to resource mobilisation and has made proactive efforts to secure a bigger budget in 2011.

Also, EFCC has been very successful at attracting donor funding. As at December 2007, the EFCC had received in excess of \$37 million in donor funding. ${ }^{19}$ ICPC, on the other hand, has not courted donors until recently, again based on the belief that the government should provide the resources that the organisation needs to work. The Secretary to ICPC also blamed the lack of donor support on the proposition that EFCC was set up to please the international community and its management has been very media savvy. EFCC has also dealt with high-profile cases of corruption by politically exposed persons and cases of terrorism, while ICPC has been dealing with things that are not glamorous, such as system reviews in ministries to reduce public service corruption. A DFID adviser that I interviewed advised that while EFCC often had a clear plan of what it wanted to do and how donor support would help it to meet those objectives, ICPC was often not even open to receiving external support. On occasions when it seeks donor support, it does not often articulate a vision or work plan that a donor can support. ${ }^{20}$

\section{$\underline{\text { Recruitment Process }}$}

The pioneer staff of ICPC was seconded largely from the Police and the Ministry of Justice. Many of those seconded returned to their parent organisation within two or three years. On the other hand, the pioneer staff of EFCC were sourced from the security community, such as the State Secret Service and the National Intelligence Agency. Those sourced from the police were from its fraud prevention unit.

19 Accessed from the EFCC website on 2 June 2011 at http://www.efccnigeria.org/index.php?option=com_content\&task=view\&id=36\&Itemid=34

${ }^{20}$ My interview with Jens-Peter Dyrbak, DFID Adviser on 1 March 2011. 
Both EFCC and ICPC adhere to the Public Service Rules published by the Office of the Head of the Civil Service of the Federation. Therefore, all recruitment is openly advertised and candidates are selected through a transparent selection process. The constitutional provisions of Federal Character are applied to ensure that all parts of the country are represented in the Commissions. The EFCC initially got off the ground by purposively selecting the officers it had identified as having a track record of competence and honesty, and requesting them from other organisations. The issue of Federal Character did not come into play and recruitment was done on the basis of personal recommendation, track record and trust, complemented by rigorous background checks. Recruitment has since become open and transparent. When I asked a focus group of EFCC officers on 13 March, 2012, why I had never seen an advertisement by the Commission, they explained that the Commission always advertises but does not identify itself. It only says that 'a reputable security agency' is seeking new recruits. They opted for this approach, given the risk that if they identified themselves, even corrupt people or their agents would apply in order to infiltrate the agency.

\section{Performance Management}

ICPC uses the same Annual Performance Evaluation and Review process that the federal civil service uses. The ineffectiveness of this process has been discussed in Chapter 1of this dissertation. EFCC, on the other hand, has a robust performance management system with which it monitors the targets set for officers. It also has a clear rewards and sanctions system: officers that perform well and meet their targets are put forward for international conferences and training courses; officers that do not perform well and fail to meet their targets are asked to leave. Ibrahim Lamorde, the EFCC Director of Operations, in his interview with me described the system and the reasoning behind it thus:

We measure performance. If you are an investigator, we ask you periodically that you must account for the cases you were asked to investigate. If you are a prosecutor you must account for cases you have taken to court. And we reward performance. If there are conferences to be attended 
outside this country, those who have performed we ask them to go, and if you haven't performed we ask you to stay. If your performance is declining, we ask you to leave. You can't do such things without evaluation. If you can't evaluate the performance of your staff, then you have people working and others being redundant. They just sit down there and flow with the tide. And they will be collecting salary; it also dampens the morals of those who are working. You have to do something to check that. ${ }^{21}$

\section{$\underline{\text { Pay and Conditions of Service }}$}

EFCC and ICPC operate the same pay scales and conditions of service. The Secretary of ICPC says that the pay and conditions enjoyed by officers is sufficiently motivating and that any performance inadequacies in the Commission cannot be blamed on pay and conditions of service. Officers of both organisations earn considerably more than civil servants in the ministries.

\section{Technical Capacity}

An important distinction in the way that both organisations work is that EFCC accepts Plea Bargain but ICPC does not. Plea bargain is a process through which an accused person can plead guilty to reduced charges and forfeit the property she has fraudulently acquired in exchange for a lighter jail sentence. This practice is not explicitly provided for under Nigerian law and is more commonly used in the United States of America. As a matter of policy, all ICPC cases go through the entire court process. No plea bargaining is allowed. ICPC thinks that the effort should be on speeding up

\footnotetext{
${ }^{21}$ My interview with Ibrahim Lamorde, Director of Operations, EFCC, on 22 December, 2010.
} 
the administration of justice and that, although Plea Bargain may be a pragmatic way to get around the slow judicial process, it is alien to Nigerian law and an aberration.

EFCC focuses more on corruption by highly placed individuals in society. Its mantra is "No one is above the law". In prosecuting senior people like ministers, governors, permanent secretaries and managing directors, EFCC sends a clear message that being a member of the elite will not insulate you from the law. Nigerians watched in disbelief when Tafa Balogun, the then Inspector General of Police (and Ribadu's boss at the time) was brought to court in handcuffs like a common criminal. ICPC, on the other hand focuses more on corruption within the public service. The Secretary of ICPC described EFCC's approach as "focussing on the monkey plucking the fruits, but neglecting the millions of termites that are eating the roots." 22 ICPC has been known to intervene in cases involving bribes of N1,000 (\$6).

EFCC places a high premium on asset recovery. Its mentality is that, as much as possible, assets stolen from the public purse should be recovered and returned, so that the government can use it to provide public goods for citizens. ICPC has much less of a focus on asset recovery. Indeed the Head of the Investigations Department said "Asset recovery grieves me. Officers here are not trained in asset recovery and there needs to be a mind-shift in this regard." ${ }^{23}$ The Secretary to the Commission confirmed that ICPC does not even analyse the assets recovered to be able to relate it to the Commission's performance.

The ICPC Act centres a lot of powers on the Chairman of the Commission. Of the 71 sections of CPA 2000 (including title, commencement and interpretation of terms), 10 sections relate specifically to the Chairman of the Commission. ICPC interprets the provisions of these sections, and the powers conferred on the Chairman, literally. Therefore, when the Chairman is not in the office, or is indisposed, a number of things just stop. EFCC

\footnotetext{
${ }^{22}$ My interview with Elvis Oglafa, Secretary to ICPC, on 16 March, 2011.

${ }^{23}$ My interview with Sotonye Wakama, Head of Department of Investigations, ICPC on 21 March, 2011.
} 
works in a much more decentralised manner and the EFCC Act 2004 gives powers to the Commission, rather than to the Chairman.

ICPC focuses a lot of effort on public education about the ills of corruption. It has successfully introduced issues of civic education, values and anticorruption into curriculum for schools. It has facilitated the setting up of more than 300 anti-corruption clubs throughout the country and has introduced the National Anti-Corruption Volunteer Corps (NAVC) to enable citizens to get involved in the anti-corruption fight. EFCC has a similar facility through its Anti-Corruption Revolution (ANCOR) campaign and has also influenced civic education in schools.

However, as the ICPC Head of Investigations points out, two-thirds of CPA 2000 deals with enforcement, not education. "If you ask the man on the street what ICPC does, they will say it is to arrest corrupt persons [...] People here have a civil service mentality. EFCC has a law enforcement mentality. They cut to the chase." 24

While ICPC wants to prove every single allegation on the charge sheet beyond reasonable doubt, EFCC is happy to get conviction on just one charge and then use that conviction to recover all stolen resources in possession of the convict, as allowed by both the EFCC Act 2004 and CPA 2000.

ICPC has better checks and balances than EFCC. In EFCC, the Legal and Prosecution Department does both investigation and prosecution. In ICPC, the Legal department which is responsible for prosecution is completely different from the Investigations Department. This means that the Legal Department can take an independent and dispassionate view about the viability of a case before recommending it for prosecution. While this is a positive attribute, investigators can often view it as an impediment. Some may prefer for ICPC just to act on what it has and leave the interpretation of the law to the courts.

\footnotetext{
${ }^{24}$ My interview with Sotonye Wakama, Head of Department of Investigations, ICPC on 21 March, 2011.
} 
Both organisations are reputed to be polite and courteous to suspects. ICPC hardly detains any suspect that honours its invitation to provide evidence about a matter under investigation. EFCC, on the other hand (at least under Ribadu) has been known to employ some underhand tactics. For instance, where a suspect evades arrest, EFCC has been known to detain the suspect's children or spouse to force the suspect to come out of hiding (Adebanwi, 2010, p.52). Although effective, the legality of this approach of detaining innocent family members is highly questionable. Since coming into office, Waziri has ensured that EFCC discontinues this tactic and operates strictly within the bounds of the law.

The use of modern technology is very limited in ICPC. The Commission does not even have a forensic laboratory and information about cases is still stored in paper files. Apart from the Chairman's speeches, the Commission's website contains very little information and a number of pages are out of date. As at June, 2011, many pages in the ICPC website were last updated in 2008 and the site does not contain information about records or convictions, numbers of petitions received, ongoing cases or recent news. One newspaper claims that it does not even contain the name of the Act that established it, only the names of its chairmen and three commissioners (This Day newspaper, 2011e). I could not independently verify this claim as the ICPC website was down when I attempted to do so on 15 June 2011 and again on 24 March 2012.

EFCC deploys technology much more effectively. It is easy to find information on organisational performance, the list of wanted persons and recent publications on the EFCC website. EFCC also uses technology to track suspicious financial transactions and movements of large sums of money by individuals. EFCC's Eagle Claw software identifies fraudulent emails, monitors them and shuts them down. In the first three months of deploying the software, 1,200 fraudulent email addresses were shut down and 20 fraudsters arrested. Similarly, the Eagle Eye software supports tax investigations, and the GoAML and GoCase software support case management in the Commission. 


\section{Public Support}

The public has a greater awareness of EFCC than ICPC, although ICPC was established four years before EFCC. A National Crime Victimization Survey undertaken in 2005, just one year after EFCC commenced operations, showed that $59 \%$ of respondents were aware of EFCC, against $46 \%$ for ICPC (CLEEN, 2005). The Convention on Business Integrity's Report on the Public Perceptions of the Anti-corruption Agencies (Convention on Business Integrity, 2009) measured "Top of Mind Awareness" and "Total Awareness" among 1,000 respondents across the country. "Top of Mind Awareness" of EFCC was $81 \%$, compared to ICPC's 16\%; and "Total Awareness" of EFCC was $99 \%$, compared to ICPC's 59\%. The independent study was funded by the British High Commission, the European Community and the United Nations Office on Drugs and Crime.

In terms of perceptions of effectiveness, the National Victimization Crime Survey, 2005, shows that EFCC was perceived to be doing a "very good or good job" by $91 \%$ of respondents, compared to $84 \%$ for ICPC. The gap in the perception of both organisations had widened considerably by 2009 . In the Convention on Business Integrity Report on the Public Perceptions of the Anticorruption Agencies, $72 \%$ of respondents believed that EFCC was "truly fighting corruption", compared to just 3\% for ICPC. The NOI Polls'

Perceptions of Effectiveness, Confidence and Corruption in Government Institutions and Agencies in Nigeria (NOI Polls, 2007; 2008; 2009) measures the perceived "effectiveness" of organisations. Average perception over 3 years shows that $60 \%$ of respondents perceived EFCC to be effective, compared to $45 \%$ for ICPC.

The EFCC actively cultivates its relationship with the media. From EFCC's inception, Ribadu often reiterated the need to get Nigerians to know about the EFCC and the new law setting it up. He regularly cited the celebrated success of NAFDAC in creating public awareness about its work. Ribadu was eager for such success. He cultivated 'activist' journalists, especially those that had regularly exposed corruption in public life, to his side and he and EFCC subsequently built a network of friends in the media (Adebanwi, 2010, pp.39-45). Also, whenever EFCC arrests or brings a suspect to court, their operatives can be seen wearing distinct red waistcoats with the name of the organisation boldly emblazoned on it. 
ICPC has been headed by retired Judges. By their training and inclination, judges worldwide are traditionally media-shy.25 The last ICPC Chairman made more of an effort to connect with the media than did the pioneer chairman. However, inadequate funding, resulting from insufficient efforts to mobilise resources, meant that the level of media activity that could be engaged in was limited.

In focus group discussion with officers of both organisations, there was a general feeling that any perceptions of insufficient or diminishing effectiveness would have been borne out of misconceptions by members of the public about the way the organisations work. Both organisations identified the need to connect better with the public as a key priority.

\subsubsection{External Factors}

External factors are those factors, often outside the organisation's control, that affect its creation, operation, performance and survival. These include political and policy considerations (including autonomy and political interference), institutional factors and the expectations that policy makers have of the organisation. I will now assess the external factors as they affect EFCC and ICPC.

\section{Political and Policy Considerations}

Every government in Nigeria (military and civilian) has promised to fight corruption and has set up various initiatives to do so. For the first time though, in 2000, President Obasanjo set up a specific organisation, ICPC, to fight corruption. Before he became President in 1999, Obasanjo had been a member of the Transparency International board. On the day that he was sworn into office, Nigeria was ranked by Transparency International as the

25 "Judges and the Media", Bench and Bar Experiences, accessed from the internet on 6 June 2011 at http://johndimotto.blogspot.com/2010/01/judges-and-media.html 
second most corrupt country on earth. Therefore, setting up the ICPC was done out of personal conviction, rather than in response to any particular pressures other than the embarrassment factor that the Transparency International rating carries.

The setting up of EFCC was a completely different matter. EFCC was set up largely in direct response to the blacklisting of Nigeria by the Financial Action task Force (FATF). In addition though, there was growing resentment in Nigeria about the lack of effectiveness of ICPC. At the time that EFCC was set up, the ICPC had only recorded one conviction, that of a local government chairman that was convicted for awarding a contract without budgetary approval.

The FATF is an intergovernmental body that tracks the trends in money laundering and the financing of terrorism and promotes the measures to tackle these among its 34 member countries. FATF has a plan of action that is anchored on 40 recommendations that states should implement. Following the terrorist attacks in the United States on September 11, 2001, FATF's mandate was expanded to deal with terrorism and it published another set of 8 recommendations to deal with terrorist financing. In 2000 and 2001, FATF extended its focus beyond its member states and reviewed the laws and regulations of 47 countries against a set of 25 criteria. Nigeria was one of the countries reviewed and found to be severely lacking. It was therefore declared non-cooperative and placed on the list of Non Cooperative Countries and Territories (NCCT). In 2002, the United States Treasury issued an advisory warning to its financial organisations to use extra caution and scrutiny when dealing with transactions involving Nigeria (Ribadu, 2010, p.60).

The effect of Nigeria's inclusion on the list of NCCTs was far-reaching and damaging. Nigerian businesses found it difficult to do business with many developed countries and many international financial organisations around the world viewed anything coming out of Nigeria with great suspicion. While the government was initially blissfully unaware of Nigeria's inclusion on the list of NCCTs and the damaging effect it was having, local banks and business knew and felt it directly (Ribadu, 2010, p.11). Nigerians travelling abroad were subjected to humiliating searches, security screening and 
financial scrutiny at airports, and the media raised a loud alarm and called on the government to do something.

At about the same time, Nigeria was seeking to obtain debt forgiveness of $\$ 30$ billion from the Paris Club of creditors. There was little chance of donors granting the debt relief while Nigeria continued to be blacklisted by the FATF.

In summary, while ICPC was set up out of the personal conviction of the President, there was an imperative to set up EFCC and give it the powers that it has. That imperative was as a result of a convergence of interests between the government, the private sector, the media and citizens.

\section{Institutional Factors}

EFCC and ICPC operate under the same institutional conditions. They go through the same processes to obtain government funding, operate the same public service rules, deal with the same historical, cultural and societal issues and are subject to the weaknesses of the same judicial and legislative system. However, while EFCC has found a way to negotiate through the institutional constraints to deliver its outputs, ICPC has been trapped by those constraints.

\section{Clarity of Expectations}

It is arguable that the government's expectations are clearly set out in the laws setting up both organisations. However, enacting a law does not necessarily mean that anything is expected from the organisation that it creates. President Obasanjo clearly expected ICPC to respond to his determination to repair Nigeria's poor image about corruption. Also, the priority for EFCC was to get Nigeria off the FATF's list of NCCTs.

In practice, President Obasanjo had not even met Nuhu Ribadu, his new head of EFCC, until Ribadu had been in the job for three months and had started to obtain visible high-level results, noticed both by the United States Ambassador and the United Kingdom High Commissioner to Nigeria 
(Adebanwi, 2010, p.98). It is a matter for conjecture what would have become of the EFCC if Ribadu had not started getting visible results almost from the first day.

My interviews with the leadership of NAFDAC and FIRS, as well as elite interviews with ministers and special assistants to the president suggest that it is visible performance first that gets the attention of the president who then sets more challenging goals. Organisations that do not perform are simply left to their own devices and are provided with just enough budgetary provisions to keep them ticking over.

\subsection{Demand}

\section{EFCC}

It is clear that global conditions created by the global efforts against money laundering and terrorism financing (particularly the listing of the country as a NCCT by the FATF), and the events of September 11, 2001, placed considerable pressure on Nigeria. Nigeria was also seeking debt forgiveness from the Paris Club of creditors at about the same time. This pressure was complemented by national pressure from local businesses and banks who found it difficult to do business with foreign countries or to obtain funds from international finance organisations. The ordinary Nigerian citizen faced harassment, unusual scrutiny and humiliating searches when travelling abroad and the media commenced a campaign to get the government to act.

The convergence of these factors created a demand for action, in the context of demand as used in this study, i.e., a desire to do something, backed by the ability to make it happen, and a willingness to deploy that ability. That demand created favourable institutional conditions and the leadership of the organisation complemented it with effective organisational conditions. Nuhu Ribadu, pioneer Chairman of EFCC refers to the Financial Action Task Force as "a necessary catalyst" (Ribadu, 2010, p.57). 
EFCC has produced atypical performance and sustained it for the period circumscribed for sustainability in this research, i.e., two electoral cycles $(8$ years in Nigeria) or two tenures of the chief executive (also 8 years in the case of EFCC).

My Hypothesis H1, that in dysfunctional environments, the prior condition for achieving sustainable atypical public sector performance is demand, is therefore supported.

\section{$\underline{\text { ICPC }}$}

ICPC was created as a result of the personal convictions and antecedent of former President Obasanjo. There was no new overriding national pressure, particularly as every single government since Nigeria's independence had pledged to tackle corruption. Other than general public disillusionment, and perhaps personal embarrassment for the President, there was nothing to lose if ICPC failed to perform. There was, therefore, no imperative for immediate action that arose out of a convergence of interests between government, citizens and civil society (including the media and private sector), as was the case with EFCC.

As the law that created ICPC vested it with considerable powers, and the President, some members of the National Assembly, the judiciary and civil society protected ICPC from having its powers watered down in 2003, it could be said that the institutional conditions for ICPC to perform well were favourable. However, the organisational conditions in ICPC have not been effective. This has meant that the organisation has only performed typically in its 11 years of existence. This confirms my proposition that where there are favourable institutional conditions but organisational conditions are ineffective, the organisation will perform typically and any atypical performance will be brief and unsustainable. 


\subsection{Methodology}

Every effort was made to be faithful to the methodological plan set out in Chapter 3, although I have had to make some adjustments in the field. In this section, I will now describe how I built this case study on anticorruption.

I reviewed a large body of literature and spoke with a wide range of people. A comprehensive account of Ribadu's time in EFCC (A Paradise for Maggots, by Wale Adebanwi) was published in 2010 with Ribadu's cooperation. Ribadu himself published another book (My Story; My Vision) in the same year, which was a personal account of his time at EFCC and his vision for the future. Given that there was a lot of literature on EFCC, I concentrated the fieldwork more on studying ICPC. However, I still went through a process of verification and triangulation in EFCC.

ICPC is not written about as often as EFCC is and what is written tends to be dismissive of the organisation without focusing on facts or hearing its own side of the story. The organisation therefore felt that researchers had not been fair to it in the past. In order to ensure that my account of the organisation was balanced and fair, I presented my findings to the Secretary of ICPC on 9 August, 2011. He confirmed that I had accurately depicted the situation in ICPC in terms of facts, and that he was happy to respect my right, as a researcher, to form opinions based on the facts.

\section{Interviews}

The list of people interviewed is shown below, as are the lines of enquiry pursued with them. All interviews were conducted in Abuja, Nigeria (unless otherwise shown), over a 16-month period between December 2010 and March, 2012. Table 7 provides a comparison against my methodological plan: 


\begin{tabular}{|c|c|c|c|}
\hline $\begin{array}{l}\text { Planned } \\
\text { Respondents }\end{array}$ & Actual Respondents & Lines of Enquiry & Tool \\
\hline $\begin{array}{l}\text { Relevant } \\
\text { Ministers and Top } \\
\text { Politicians }\end{array}$ & $\begin{array}{l}\text { 1. Olusegun Obasanjo, } \\
\text { former President of } \\
\text { Nigeria (interviewed in } \\
\text { Abeokuta, Ogun State, } \\
\text { Nigeria) on } 29 \text { October, } \\
2011 \\
\text { 2. Donald Duke, former } \\
\text { Governor of Cross River } \\
\text { State, Nigeria, on } 2 \\
\text { February, 2012 } \\
\text { Amina az Zubair, Senior } \\
\text { Special Assistant to the } \\
\text { President on Millennium } \\
\text { Development Goals and } \\
\text { member of the } \\
\text { Presidential Economic } \\
\text { Team on, 20 April, 2011 } \\
\text { Rueben Abati, Senior } \\
\text { Special Assistant to the } \\
\text { President on Media and } \\
\text { Publicity, (interviewed } \\
\text { on British Airways flight } \\
\text { from Abuja, Nigeria to } \\
\text { London, UK) on 18 } \\
\text { November, 2011 Nor } \\
\text { Frank and Nweke, Jnr., } \\
\text { Former Minister for } \\
\text { Information } \\
\text { Communications, on } 2 \\
\text { February, 2010. }\end{array}$ & $\begin{array}{l}\text { The source of } \\
\text { pressure/ } \\
\text { demand for } \\
\text { change/ political } \\
\text { environment } \\
\text { prior to reforms } \\
\text { If and when a } \\
\text { decision for } \\
\text { improvement } \\
\text { was made, why } \\
\text { and by whom. } \\
\text { How the } \\
\text { conditions for } \\
\text { improvement } \\
\text { came into play. } \\
\text { Hierarchy of } \\
\text { conditions. }\end{array}$ & $\begin{array}{l}\text { Semi- } \\
\text { structured } \\
\text { interviews }\end{array}$ \\
\hline $\begin{array}{l}\text { Past and present } \\
\text { Chief Executives }\end{array}$ & $\begin{array}{l}\text { 6. Nuhu Ribadu, pioneer } \\
\text { Chairman of EFCC, on } 7 \\
\text { December, } 2010 \text {. } \\
\text { 7. Ibrahim Lamorde, Director } \\
\text { of Operations, EFCC, (became } \\
\text { Chairman of EFCC in 2012) } \\
\text { 8. Elvis Oglafa, Secretary to } \\
\text { the Commission, ICPC, on } 16 \\
\text { March, } 2011 \text { and } 8 \text { August } \\
\text { 2011 (ICPC has not had a } \\
\text { substantive Chairman since }\end{array}$ & $\begin{array}{l}\text { - The source of } \\
\text { pressure/ } \\
\text { demand for } \\
\text { change. } \\
\text { If and when a } \\
\text { decision for } \\
\text { improvement } \\
\text { was made, why } \\
\text { and by whom. } \\
\text { How the } \\
\text { conditions for } \\
\text { improvement } \\
\text { came into play. }\end{array}$ & $\begin{array}{l}\text { Semi- } \\
\text { structured } \\
\text { interviews }\end{array}$ \\
\hline
\end{tabular}




\begin{tabular}{|c|c|c|c|}
\hline & late 2010). & $\begin{array}{l}\text { Hierarchy of } \\
\text { conditions }\end{array}$ & \\
\hline $\begin{array}{l}\text { Officers- Low, } \\
\text { Middle and Senior } \\
\text { Management } \\
\text { Level }\end{array}$ & 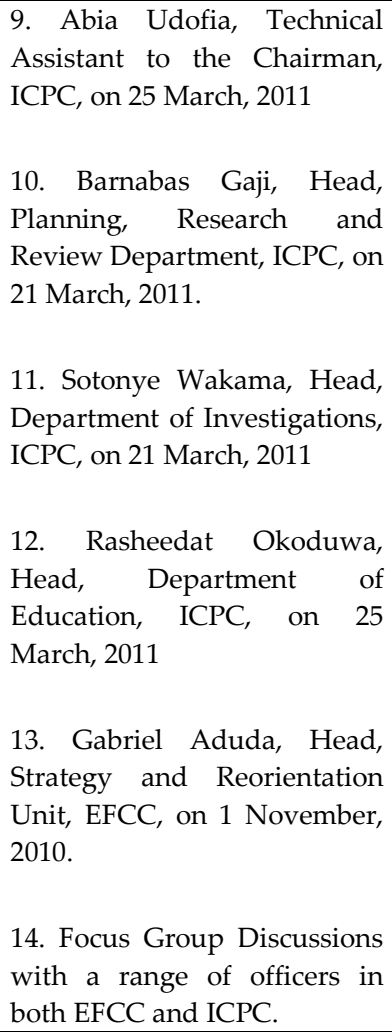 & $\begin{array}{ll}\text { - } & \text { External and } \\
\text { Internal Factors } \\
\text { affecting } \\
\text { performance } \\
\text { - } \\
\text { Internal } \\
\text { organisational } \\
\text { and management } \\
\text { arrangements }\end{array}$ & $\begin{array}{l}\text { Semi- } \\
\text { structured } \\
\text { interviews }\end{array}$ \\
\hline $\begin{array}{l}\text { Civil Society/ } \\
\text { Media } \\
\text { Representatives }\end{array}$ & $\begin{array}{l}\text { 15. Jibrin Ibrahim, Executive } \\
\begin{array}{l}\text { Director, Centre for } \\
\text { Democracy } \\
\text { Development, on } \\
\text { September, } 2011\end{array} \\
\begin{array}{l}\text { 16. Soji Apampa, Director, } \\
\text { Convention on Business }\end{array} \\
\begin{array}{l}\text { Integrity, on 2 October, 2011. } \\
\text { and }\end{array}\end{array}$ & $\begin{array}{ll}\text { - } & \begin{array}{l}\text { The source of } \\
\text { pressure/ } \\
\text { demand } \\
\text { change }\end{array} \\
\text { - } & \begin{array}{l}\text { Hierarchy } \\
\text { conditions }\end{array}\end{array}$ & $\begin{array}{l}\text { Semi- } \\
\text { structured } \\
\text { interviews }\end{array}$ \\
\hline $\begin{array}{l}\text { Private sector } \\
\text { representatives }\end{array}$ & $\begin{array}{l}\text { 17. Convention on Business } \\
\text { Integrity }\end{array}$ & $\begin{array}{l}\text { - The source of } \\
\text { pressure/demand } \\
\text { for change } \\
\text { - Hierarchy of } \\
\text { factors }\end{array}$ & $\begin{array}{l}\text { Semi- } \\
\text { structured } \\
\text { interviews }\end{array}$ \\
\hline
\end{tabular}




\begin{tabular}{|c|c|c|c|}
\hline Donors & $\begin{array}{l}\text { 18. Jens-Peter Dyrbak, } \\
\text { Governance Adviser, DFID, } \\
\text { on } 1 \text { March, 2011. } \\
\text { 19. Thomas Maettig, Country } \\
\text { Representative, FES, on } 4 \\
\text { August, 2011. } \\
\text { Sina Fagbenro, } \\
\text { Governance Adviser, DFID, } \\
\text { (interviewed in Ado-Ekiti, } \\
\text { Ekiti State, Nigeria) on } 26 \\
\text { January 2011. }\end{array}$ & 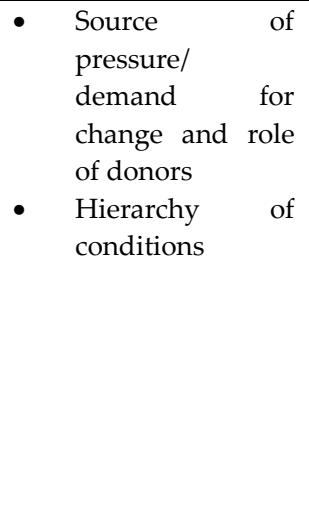 & $\begin{array}{l}\text { Exploratory } \\
\text { and semi- } \\
\text { structured } \\
\text { interviews }\end{array}$ \\
\hline Service Users & $\begin{array}{l}\text { 21. Asishana Okauru, pioneer } \\
\text { Head, National Financial } \\
\text { Intelligence Unit, EFCC, on } 7 \\
\text { December } 2010 \\
\text { 22. Goke Adegoroye, former } \\
\text { Permanent Secretary, Bureau } \\
\text { of Public Service Reform, on } \\
\text { 22 March, 2012. } \\
\text { 23. Chike Ogbechie, Director, } \\
\text { National Salaries, Incomes } \\
\text { and Wages Commission, on } \\
\text { 23 June, 2011. }\end{array}$ & 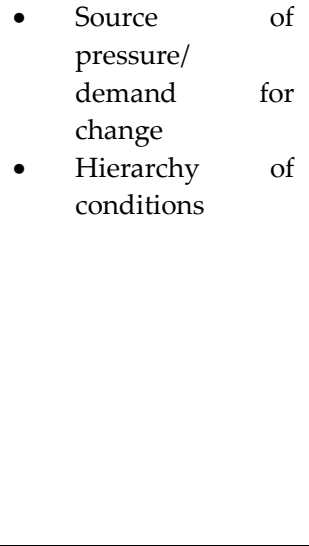 & $\begin{array}{l}\text { Semi- } \\
\text { structured } \\
\text { interviews }\end{array}$ \\
\hline
\end{tabular}

Table 7: Anticorruption Case Study: Comparison with Methodological Plans

\section{Focus Group Discussions}

I was fortunate to have been able to hold focus group discussions in both organisations. The focus group discussions in each organisation segmented three levels of officers: Senior, Mid-level and Junior, based on natural demarcations between grade levels. Before I started each focus group discussion, I outlined the ethical issues that will govern the discussions:

- No comments will be attributed to any individual or department

- Notes of discussions will only be used for academic purposes 
- Voice recording of discussions will only be done on the express permission of all discussants.

In both organisations, discussants preferred not to have their voices recorded. Therefore, I took notes with the help of a research assistant.

Each set of participants in each organisation were asked the same four questions:

1. What are your views about how your organisation is managed in terms of Leadership, Human Resources, Technical Capacity and Public Support?

2. Your organisation is perceived to be not as effective as it could be (ICPC)/ not as effective as it used to be (EFCC). Is this public perception fair?

3. What are the two greatest strengths and the two greatest weaknesses of your organisation?

4. If your organisation is to improve its performance, what should it be doing differently?

Their responses have been integrated into the discussions on the dependent and independent variables in the body of this chapter.

List of Participants in Focus Group Discussions held at ICPC Headquarters, Abuja, Nigeria on 8 August, 2011:

Group 1 (Units Heads)

1. Mr. Chidi Kalu (Head Audit)

2. Mrs. Florence Oyatoye (Head Clinic)

3. Mrs. Sule Yahaya(AD Admin )

4. Ms Uloma Olekanma (AD HRM)

5. Mr. Lucky Nwosu (Head Library) 
Group 2 (Levels 10-12)

1. Wellington O. Nkemadu (SDD)

2. Emeoha Chinyere (Admin)

3. Jafaru Usman (PRR)

4. Angela E. Aziegbe (Investigations)

5. Oforah Obinna F. (Public Enlightenment)

6. Ambrose T. Sango (Audit)

7. West Gogodaye P. (CSU)

Group 3 (Levels 6-7)

1. Shittu Ann Ireti (PRR)

2. Nathan Onyebuchi (Legal)

3. Anzizi Patience (Clinic)

4. Ismaila Ahmed (FIU)

5. Lucky N. Elekwachi (Admin)

6. Suleiman Bulama (Accounts)

7. Ibrahim Yahaya (Education)

\section{List of Participants in Focus Group Discussions held at EFCC} Headquarters, Abuja, Nigeria, on 13 March 2012.

Although EFCC convened the same three levels of officers for the focus group discussions, they split them into two mixed groups and did not segment them according to seniority, as originally designed. While this had the advantage of enhancing differing perspectives and debate in each group, I had to ensure that the discussions were not dominated by people who appeared to be the more senior officers. For instance, I ensured that the female discussants were able to be heard and did not have their voices drowned out by the men. It was difficult to know who was who as the attendees would only identify themselves by their initials, for security purposes. 
Group 1

\begin{tabular}{|l|l|l|}
\hline Name & Designation & Department \\
\hline P.F.S & ADS & \\
\hline D.O. & ADI & ISOS \\
\hline M.N.T. & D.I & CTGI \\
\hline W.E. & & FORENSICS \\
\hline M.M.A. & ADS & CTGI \\
\hline M.Y. & DSP & CTGI \\
\hline D.O.N. & DDS & CTGI \\
\hline & & BF \\
\hline
\end{tabular}

Group 2

\begin{tabular}{|l|l|l|}
\hline Name & Designation & Department \\
\hline B.C. & & \\
\hline J.O. & & EG \\
\hline A.D.E. & & AFF-I \\
\hline U.S. & & AFF-OPERATIONS \\
\hline M.K. & & AFF \\
\hline M.M. & & EG \\
\hline E.E. & & SERVICOM \\
\hline
\end{tabular}

\subsection{Conclusions}

In this chapter, I have tied together my explanatory variable, conceptual framework and the various propositions in the literature and tested them in the context of two similar organisations. The exercise has produced findings that confirms or challenges various aspects of the literature on the subject. I have also evaluated my working hypothesis and the propositions from my 
conceptual framework and found that, with respect to the atypical organisation studied, my initial hypothesis appears to be supported.

With regards to the typical organisation studied, I have also found that the relevant proposition in my conceptual framework was supported.

The combination of internal and external factors that converged at the right time to create an unprecedented momentum to root out fraud and corruption in Nigeria could be difficult to replicate. Yet some lessons can be drawn for both the outside world, as well as Nigeria itself (Ribadu, 2010, p.134).

In the next chapter we will assess the extent to which similar internal and external factors converged to create a momentum in another field (Regulatory Quality) and in the activities of two more organisations, NAFDAC and SON. 


\section{Chapter 5 Regulatory Quality: Against the Odds}

If you are a gun manufacturer, the product you make is not subject to safety regulation by the Consumer Product Safety Commission. Toy guns are subject to safety regulation; water pistols are, but not real guns. (Barnes, date unknown)

\subsection{Abstract}

In this chapter, we study two organisations: the Standards Organisation of Nigeria (SON) and the National Agency for Food and Drugs Administration and Control (NAFDAC). This chapter continues the process of theory-building that started from my main literature review chapter through to the case study on anti-corruption in the previous chapter. This chapter concludes that the same internal and external factors that affected EFCC's performance in the previous chapter also affected NAFDAC's performance, and that demand was a key ingredient in the reforms in NAFDAC. However, it is not apparent that there was an immediate imperative for change at a specific point in time here as there was in EFCC, since the pressures on NAFDAC to tackle fake drugs had always existed.

\subsection{Introduction}

The chapter starts with the context in which the key issues pertaining to these case studies are to be discussed. It then sets out the background and history of each organisation and explores the application of the explanatory variables for this research to my research question. Next, the findings about why one organisation performs better than the other are analysed and explained. Finally, it further develops and refines my understanding of 
what brings about atypical performance in difficult institutional environments.

The EFCC case study in Chapter 4 tentatively supports the proposition that a mixture of factors converged at the right time to provide an unprecedented momentum to the war against corruption in Nigeria (Ribadu, 2010). This convergence, combined with the power to bring about the desired change is what is currently described as demand in the context of this research. However, it could be argued that the EFCC is performing well because it was designed from the start to perform atypically and that the combination of factors that shaped its atypical performance is so unusual that any theory built from it will be narrow and idiosyncratic. Where the set of circumstances that shaped organisational performance are entirely unique, it could be argued that any findings from a case study of that organisation are unsafe to raise to a general level of theory (Eisenhardt, 1989, p.547). To address this concern, it is important to study organisations that could not also be said to have been deliberately designed to perform atypically, and where the factors that appear to have shaped performance may not have converged in quite the same way. For instance, where such organisations were already in existence and had performed poorly for a number of years before changing course to achieve atypical performance, it is unlikely that they would have been deliberately designed from the start to achieve atypical performance. Even where there are characteristics in the original conception of these organisations that could lead to a claim that they were designed from the start to be atypical, the fact that they performed poorly for a number of years would suggest that it is not enough just to design an organisation to be atypical. Indeed, it could be argued that the ICPC, given the unusual powers that it was given from inception, was designed to be atypical but has never been able to achieve the level of performance that was envisaged by its initiators.

In studying SON and NAFDAC, it is important to return to the research question that this dissertation is trying to answer: How and why are certain public sector organisations able to achieve atypical performance in dysfunctional environments? Without constantly keeping the research focus in mind, it is easy to become overwhelmed by the volume of data when conducting case study research (Eisenhardt, 1989, p.536). Performance that can be statistically expressed as 1 standard deviation from the mean 
(where there is quantitative data) could be seen as atypical. The term atypical is used in the sense of atypically-strong, rather than atypically weak. A dysfunctional environment is one in which, by the institutions and structure of society, nothing is expected to work.

The term Regulatory Quality is used in various contexts in the literature to mean various things. To some authors, it refers to the quality of regulation, i.e., how good a particular piece of regulation is (Radaelli, 2004; Braithwaite, 2007). To other authors (Stiglitz, 1998; Laffont, 1999; Kauffman and Kraay, 2002), it refers to the effectiveness of the institutions and processes for regulation in a country. This research does not focus exclusively on the quality of particular pieces of regulation in the way that a Regulatory Impact Assessment (Radaelli, 2004) does. It does however provide commentaries on the legal instruments setting up and guiding the operations of certain organisations and the benefits and constraints that those instruments provide to the specific organisation in the fulfilment of its mandate.

The term Regulatory Quality in this research is used to refer to the effectiveness and efficiency of certain organisations that perform regulatory functions. Effectiveness is assessed using the organisation's ability to reduce the incidence of fake and substandard products; and efficiency refers to the level of success achieved with the set of inputs that the organisation has at its disposal.

I argued in Chapter 3 that weak governance environments might often be weak on the enforcement of regulations, and that the successful enforcement of standards by one organisation might be suggestive of atypical behaviour. Various authors have similarly argued that there is a correlation between the quality of regulatory institutions and organisations and a country's quality of governance (Olsen, et al., 1998; Kauffman and Kraay, 2002). Therefore, the ability of a state to provide effective regulatory institutions will be an important determinant of how its economy performs (North, 1990; World Bank, 2002; Rodrik, et al., 2004; Jalilian, et al., 2006).

A good regulatory system is one that balances accountability, transparency and consistency (Parker, 1999, p.224; Jalilian, et.al; 2006; p.9). Accountability refers to compliance with due process and the accountability for actions 
taken within the given legal powers that the organisation is given. Transparency refers to the making of decisions in a way that is not opaque, and consistency refers to the predictability of decision-making and the avoidance of uncertainty.

The analysis in Chapter 3 of this research shows that, in a survey of 19 agencies in Nigeria, the performance of the National Agency for Food and Drugs Administration represents 1 standard deviation from the mean. This was triangulated with additional data (Eisenhardt, 1989, p. 538) that supports the notion that NAFDAC is an atypical performer. The Standards Organisation of Nigeria, although not part of the said survey, was chosen because it is the most natural pair for NAFDAC given its functions, and is, by all indications, underperforming like the majority of Nigerian agencies. SON has therefore been chosen to enable the replication of the previous case studies in Chapter 4 of this dissertation and to extend the theory that is emerging about how and why certain organisations are able to perform well against all odds (Eisenhardt, 1989, p.537).

Where regulatory agencies are not accountable, they can be seen by members of the public as instruments of power abuse by the elite. Where they are not transparent in their operations, they can be perceived to favour one section of the populace over the other. Where they are not consistent, they can be seen as arbitrary and unpredictable. The main consequence of weak regulatory governance is that it undermines public confidence in the regulatory system (Jalilian, et al., 2006, p.9). In the context of developing countries, it also encourages corruption since officials may reserve very wide discretionary powers to themselves, and the public may feel that they have to pay corrupt rents to escape regulation. Indeed, the underperformance of many regulatory agencies in developing countries has often been blamed on corruption, occasioned by a lack of accountability, transparency and consistency in the operations of the regulatory agencies. Also, where regulatory agencies are weak, it undermines the rule of law in a society and scares off investors.

However, the consequences of weak regulatory governance in our case study organisations can be much more serious. Weak regulation of pharmaceutical drugs can lead to death from fake or sub-standard drugs, 
and weak enforcement of manufacturing standards can lead to exploding electronics and brake failure in automobiles, both of which can cause death.

With the discovery of oil in Nigeria in 1956, the focus on industrialisation started to wane. The economy was heavily dominated by imported goods, and concerns for quality and wholesomeness of those goods were not paramount, as it was assumed that the regulatory authorities of the countries where the goods originated had ensured their quality and safety. By the time of the oil boom in the 1970s, Nigeria's then military head of state captured the mood of the nation when he said: "The problem that Nigeria has is not that of lack of money but how to spend it." (Gowon, date unknown).

As the economy grew and the volume and sophistication of consumer goods increased, some degree of local control started to be exercised through various government departments. (Institute of Public Analysts of Nigeria, 2011). However, the enforcement of standards by regulatory bodies in Nigeria is generally considered to be weak or ineffective (Apampa, 2006, p.28). Nigerians are largely unaware of the impact of most agencies and ratings of effectiveness are generally low (NOI Polls, 2007; 2008; 2009). Nigeria has also scored consistently low in the World Governance Indicators' assessment of regulatory quality, placing in the $10^{\text {th }}$ to $25^{\text {th }}$ percentile of countries, compared, for instance, to Ghana which places in the $50^{\text {th }}$ to $7^{\text {th }}$ percentile (World Governance Indicators, 2008; 2009; 2010). Regulatory quality in the World Governance Indicators refers to the ability of government to formulate and implement sound policies and regulations that permit private sector development (World Governance Indicators, 2010).

In discussing state capacity and the weak structural conditions of the African state, Jinadu (2009, p.4) blames the structural constraints on the historical push and pull of globalisation and localisation or indigenisation in Africa. He lists some of the main structural constraints as:

(a) Weak management capacity in the public service

(b) Low investment by the public and private sectors in research and development 
(c) Prevalence of endemic and preventable diseases like malaria and HIV/AIDS

(d) Kloptocratic behaviour by public officials

(e) Huge external debts

(f) Monoculture economies

(g) High levels of illiteracy

(h) Fragile and deteriorating social and physical infrastructure

(i) Brain drain

(j) Environmental degradation

The weakness in regulatory capacity in Nigeria is traceable to many of the factors listed by Jinadu, as well as effects of military rule on the public sector. Military dictatorships, by their very nature, do not lend themselves well to regulation by civil authorities. Therefore, little emphasis was placed on providing the required human and financial resources, the appropriate legal framework, or the required political and policy support. Unlike in some other countries, Nigeria has not yet undertaken a comprehensive review of agencies and parastatals for the purpose of weeding out ineffective ones or consolidating some to avoid duplication of efforts. Instead, new agencies are created by each successive administration (and given some measure of autonomy), either to deal with new challenges or to focus more directly on a particular issue. This is often seen as an easier and quicker option, rather than attempting to reform an existing agency which already had that same mandate. Quite often, the government will often create new agencies or grant new autonomies in response to some internal or external pressure.

Consequently, many agencies duplicate the functions of other agencies and spend their time engaged in turf-wars with other agencies over mandates and functions. Nigeria's National Programme of Action 2008 following the African Peer Review Mechanism assessment recognises this problem. One of the actions that the country agreed to take was to "Streamline regulation and supervision to reduce overlap or arbitrage opportunities that could be exploited. More coordination and inter-agency cooperation is called for" (Jinadu, 2009, p.12).

Akunyili (2010, p.179-220) lists the factors militating against effective food and drug regulation as: 
- Corruption and conflict of interest

- An insecure and unfriendly environment

- Inadequate legislation

- Evasion techniques by counterfeiters

- Release without inspection

- Discriminatory export regulation by exporting countries

- Lack of consumer awareness

- Lack of political will

- Unfavourable government policies

- Political instability

- Inadequate cooperation among government agencies

- Chaotic distribution systems

- Demand for products exceeding available supply

- Inadequate computerisation

These are, in my view, of wider application than food and drug regulation, and are much of the same factors that contribute to weak regulation in Nigeria generally. Although the general understanding is that SON deals with everything, other than those covered by NAFDAC (mainly food and drugs), there are overlaps in the functions of both organisations. As the national agency responsible for setting all standards and assuring quality, SON has the de jure statutory authority to set standards, even for food and drugs. However, The NAFDAC enabling law also empowers NAFDAC to set standards for the control of food, drugs, cosmetics, medical devices, packaged water and chemicals. Both agencies have a physical presence at the ports and sometimes take conflicting actions. In my interview with Akunyili on 21 January, 2011, she narrated an incidence in which SON released a shipping container before NAFDAC had finished inspecting it. Pages 351 and 352 of her book (Akunyili, 2010) also contain letters to the Comptroller General of Customs complaining about the release of NAFDAC-regulated products by customs officers without reference to NAFDAC.

However, within this weak regulatory environment, NAFDAC has recorded significant success in regulating food and pharmaceutical drugs. Although SON has not had much success, its new leadership is now beginning to seriously tackle the incidence of fake and substandard goods. 


\subsection{The Standards Organisation of Nigeria (SON)}

\subsubsection{Brief History of SON}

The Standard Organisation of Nigeria (SON) is the sole statutory body that has the mandate of standardising and regulating the quality of all products in Nigeria. It was first established in 1971 through Act 56 by the military regime (Federal Government of Nigeria, 1971) and was called the Nigeria Standards Organisation (NSO). The Act provided the body with the authority to specify and elaborate standards, as well as provide a quality assurance system for commodities, including manufactured, industrial and imported products and services.

In 1976, the Act (Federal Government of Nigeria, 1976) was amended to confer on the Minister of Industry the power to declare Mandatory Industrial Standards in respect of products or processes recommended by the Nigerian Standards Council. The original Act was further amended in 1984 to change the name of the body from the Nigerian Standards Organisation (NSO) to the Standards Organisation of Nigeria (SON) because the acronym, NSO, created confusion with a newly established security body known as the Nigerian Security Organisation (Federal Government of Nigeria, 1984).

A further amendment in 1990 conferred partial autonomy on the SON from the Ministry of Industry. This amendment significantly strengthened the powers of SON and its corporate image. Its Chief Executive officer was designated Director-General and the amendment also provided for the strict enforcement of powers of seizure, confiscation and destruction of substandard products, including powers to seal up premises where defective products are manufactured or stored. Severe penalties for offending manufacturers, importers and sellers of substandard products were also provided for in the amended Act, (Federal Government of Nigeria, 1990a). 


\subsubsection{Functions of SON}

Section 4 of the SON Act, 1990, sets out the statutory functions of the organisation to include:

1. To organise tests and do everything necessary to ensure compliance with standards designated and approved by the SON Council;

2. To undertake investigations as necessary into the quality of facilities, materials and products in Nigeria, and establish a quality assurance system including certification of factories, products and laboratories;

3. To ensure reference standards for calibration and verification of measures and measuring instruments;

4. To compile an inventory of products requiring standardisation;

5. To compile Nigerian standards specifications;

6. To foster interest in the recommendation and maintenance of acceptable standards by industry and the general public;

7. To develop methods for testing materials, supplies and equipment, including items purchased for use of departments of the government of the Federation or a state and private and private establishments;

8. To register and regulate standard marks and specifications;

9. To undertake preparation and distribution of standard samples;

10. To establish and maintain laboratories or other institutions, as may be necessary for the performance of its functions;

11. To advise State and Federal departments of Government on specific problems relating to standards;

12. To compile and publish general scientific or other data;

13. To sponsor appropriate national and international conferences;

14. To undertake research as may be necessary for the performance of its functions;

15. To use research facilities, whether public or private, according to terms and conditions agreed upon between the Organisation and the institutions concerned.

The SON is designed to be the main reference point in matters of standardisation as well as quality and technical competence for all manufactured goods in Nigeria, imported or locally produced. It regulates 
the quality of items such as electric cables, gas cylinders and valves, textiles, household electronics, vehicle spare parts, construction material and computer equipment.

Up to early 2011, SON had been described as "docile, ineffective and silent" (Nigerian Tribune, 2010). Although everybody uses products that should be regulated by SON, many people are unaware of the existence of the organisation. For instance, it does not feature on any top-of-the-mind surveys about the effectiveness of government agencies in Nigeria that I reviewed, such as NOI Polls. However, the newly-appointed DirectorGeneral appears determined to improve the performance of the organisation and enhance its public image. At the time that the new Director-General came into post early in 2011, SON did not have a single functional laboratory. As this fundamental tool of its trade did not even exist, it was clear why the organisation was not as effective as it should be. It is difficult to regulate standards if you have no means of testing materials to determine whether or not those standards are being complied with.

\subsubsection{Mode of Operation}

The highest policy-making body of the SON is the Standards Council of Nigeria. Its main functions include:

1. Advising the Federal Government on the national policy on standards, standards specifications, quality control and metrology;

2. Determining the overall financial, operational and administrative policy of the Organisation;

3. Determining appointments, remuneration and other conditions of service.

The Federal Government, on the recommendation of the Minister of industry, appoints members of the Council. Members of the Council, who are drawn from both the public and private sectors, hold office for a term of four years. The Permanent Secretary in the Ministry of Industry is the Chairman. 
SON currently has eight Directorates under the leadership of a DirectorGeneral:

1. Standards;

2. Quality Assurance;

3. Laboratory Services;

4. Planning Research and Information;

5. Management Systems;

6. Technical Services;

7. Finance and Supply; and

8. Human Resources.

The SON Act, 1990, empowers the organisation to seize and destroy substandard goods. It also prescribes punishment for a number of offences, the heaviest of which is imprisonment for a period not exceeding one year or a fine of $\mathrm{N1,000} \mathrm{(about} \mathrm{\$ 6).} \mathrm{Given} \mathrm{the} \mathrm{possible} \mathrm{serious} \mathrm{consequences} \mathrm{of}$ substandard vehicle tyres and brake pads, for instance, it would appear that the punishments prescribed were not meant to deter or sanction anybody. The Act has not yet been reviewed to bring it more in line with current realities.

SON officials are required to carry out inspections at the ports, but they have no testing equipment and are largely perceived to be corrupt. The agency itself recently admitted that $60 \%$ of shipping containers enter Nigeria without inspection (This Day, 2011f). Even when there are token seizures of substandard imported goods, the very same substandard goods find their back way into the Nigerian market either through so-called public auctions or allegedly through rents paid to SON officials to look the other way. 


\subsection{The National Agency for Food and Drugs Administration and Control (NAFDAC)}

\subsubsection{Brief History of NAFDAC}

The first legislation to regulate pharmaceutical drugs in Nigeria was enacted in the early 1890s. The 1891 Sale of Drug Ordinance law was made to apply to the Colony of Lagos. It was later repealed and re-enacted in 1902. By 1907, the Ordinance had already being extended to the Colony and Protectorate of Southern and Northern Nigeria. After the amalgamation of Northern and Southern Nigeria in 1914, a nationwide Drugs and Poisons Ordinance was promulgated in 1915. Between 1922 and 1964, this statute had gone through a number of amendments, repeals and re-enactments. In 1964 The Pharmacy Ordinance of 1945 that repealed the 1936 legislation was renamed the Poisons and Pharmacy Act. The essential part of it was to ensure the controlled sale and use of certain drugs and poisons, (Akunyili, 2010, p.7).

The Food Adulteration Ordinance of 1903 was the first known food regulation in Nigeria. Like the Drug Ordinance, it applied only to the Colony of Lagos. The Sale of Food Ordinance of 1917 repealed the 1903 law. It became a regional legislation in 1954 due to the adoption of a federal structure for the country. After Nigeria's independence in 1960, the law was re-enacted and replaced with the Food and Drug Act of 1974. Like the Drug and Poisons law, the essential policy thrust was prohibition, rather than proper regulation (Akunyili, 2010, p.8).

In 1974, the Federal Government attempted to provide a modern institutional framework for the regulation of food and drugs. It established the Food and Drug Administration as a directorate of the Federal Ministry of Health. The main purpose of establishing this directorate was to ensure that Nigeria did not become a dumping ground for unsafe and substandard food and drugs. The government was keen to ensure that food, drugs, medical devices cosmetics, water and chemicals available in the country are of good and internationally-acceptable quality. Decree No 35, of 1974 which established the Food and Drug Administration made provisions for the control of the preparations of foods, drugs, medical devices, cosmetics, 
water and chemicals under sanitary conditions, and for the prevention of the importation and sale of those certified unfit for human use.

In the Food and Drug Administration directorate, there were quality control laboratories, provision for inspection and enforcement, and a fairly wellequipped drug-manufacturing laboratory. However, according to Akunyili (2010, p.8), there was no provision for product registration, thereby making drug importation and manufacturing a free-for-all affair.

The department was said to have experienced a number of problems which partly was responsible for its ineffectiveness. These problems were traceable to issues such as slow mobilisation of ideas, men and materials for production work; inadequate resource acquisition, utilisation and management; slow disciplinary and poor reward system and management; and poor funding of activities necessary for effective design and implementation of programmes. Besides, there was the problem of lack of awareness by the public about the effects of substandard food and drugs and the dangers that they pose to public health, (NAFDAC, undated, Information Brochure, p.2).

Civil service bureaucracy, corruption, political instability and a host of other lapses hindered the activities of FDAC (Akunyili. 2010, p.8). The problem of fake and adulterated drugs had taken a dangerous dimension as efforts to contain the menace failed. The consequence was the high death rate occasioned by the administration of unwholesome drugs. Nigeria's reputation nose-dived in the international pharmaceutical arena as confidence in the nation's health care system had been eroded. The implications included treatment failures and ailments that developed a resistance to drugs, particularly infectious diseases and malaria.

The effects of consuming counterfeit drugs generally tend to go unnoticed, except in cases where it results in multiple deaths. Although there are no general reliable data on the mortality and morbidity arising from the consumption of counterfeit drugs in Nigeria. Akunyili (2010, pp. 121-177) catalogued some shocking evidence of the consequences of ingesting fake drugs in Nigeria: 
- In 1990, 200 children died in Nigeria after taking Paracetamol syrup produced with toxic diethylene glycol solvent;

- In 2003, 2 children who had benefited from heart surgery sponsored by the Kanu Nwankwo Heart Foundation, founded by the Nigerian footballer, Kanu Nwankwo, died. The children had died as a result of fake cardiac stimulants administered on them during the surgery process; and

- In 2008, 70 children died from contaminated teething powder.

Although there were other serious cases, such as contaminated intravenous infusions, contaminated water for injections, fake anti-diabetic, antibiotic and anti-arthritis drugs, the incidences that caused the most severe public outrage were those that resulted in the death of children. As the death of children often does, this led to very loud demands for the government to act.

\subsubsection{Functions of NAFDAC}

The name of the Agency reflects its function very adequately. By the provisions of Section 5 of the enabling decree (Decree No 15 of 1993) the agency is mandated to:

- Regulate and control the importation, exportation, manufacture, advertisement, distribution, sale and use of drugs, cosmetics, medical devices, bottled water and chemicals;

- Conduct appropriate tests and ensure compliance with standard specifications designated and approved by the Council for the effective control of quality of food, drugs, cosmetics, medical devices, bottled water and chemicals and their materials as well as their production processes in factories and other establishments;

- Undertake appropriate investigation in the production premises and raw materials for food, drugs, cosmetics, medical devices, bottled water and chemicals, and establish relevant quality assurance systems, including certification of the production sites and of the regulated products; 
- Undertake inspection of imported food, drugs, cosmetics, medical devices, bottled water and chemicals, and establish relevant quality assurance systems, including certification of the production sites and of the regulated products;

- Compile standard specifications and regulations and guidelines for the production, importation, exportation, sale and distribution of food, drugs, cosmetics, medical devices, bottled water and chemicals;

- Undertake the registration of food, drugs, cosmetics, medical devices, bottled water and chemicals;

- Control the exportation and issue quality certification of food, drugs, cosmetics, medical devices, bottled water and chemicals intended for export;

- Establish and maintain relevant laboratories or other institutions in strategic areas of Nigeria as may be necessary for the performance of its functions;

- Pronounce on the quality and safety of food, drugs, cosmetics, medical devices, bottled water and chemicals after appropriate analysis;

- Undertake measures to ensure that the use of narcotic drugs and psychotropic substances are limited to medical and scientific purposes;

- Grant authorization for the import and export of narcotic drugs and psychotropic substances as well as other controlled substances;

- Collaborate with National Drug Enforcement Agency in measures to eradicate drug abuse in Nigeria;

- Advise Federal, State and Local Governments, the Private sector and other interested bodies regarding the quality, safety and regulatory provisions on food, drugs, cosmetics, medical devices, bottled water and chemicals;

- Issue guidelines on, approve and monitor the advertisement of food, drugs, cosmetics, medical devices, bottled water and chemicals;

- Compile and publish relevant data resulting from the performance of the functions of the Agency or from other sources;

- Sponsor such national and international conferences as it may consider appropriate; and 
- Liaise with relevant establishment within and outside Nigeria in pursuance of its functions.

The intention of those that drafted the law is clear. They wanted the strong regulation of food, drugs, cosmetics, medical devices, bottled water and chemicals, and wanted a strong organisation to do it.

Since 1993 when NAFDAC came into being, several other laws have been enacted to strengthen its operations. In 1999, the Counterfeit and Fake drugs (Miscellaneous Provisions) Decree No. 17 of 1989 was repealed and reenacted. It was replaced with the Counterfeit and Fake Drugs and Unwholesome Processed Foods (Miscellaneous Provisions) Decree No. 25 of 1999. Under this law, the maximum punishment upon conviction is a fine of N500, 000 (about \$3,300), or a prison sentence of between 5 and 15 years. In addition to the principal offenders, Decree No.25 of 1999 also targets persons who aid or abet drug counterfeiting, imposing the same fine upon conviction, or up to two years improvement. The decree also provided that convicts will forfeit the offending products to the government. The punishments provided under the decree was far more severe than that contained in the repealed Decree 17 of 1989 which stipulated that such offenders could not be fined more than N5,000 (about \$33), (Akunyili, 2010).

In an effort to arrest the situation the then Nigeria Head of State, General Ibrahim Babangida, dissolved FDAC on $31^{\text {st }}$ December 1992. This gave birth to the National Agency for Food and Drug Administration and Control (NAFDAC). It was established as a parastatal of the Federal Ministry of Health by Decree no 15 of 1993 (with a commencement date of 1 October, 1992) to control and regulate the manufacture, importation, exportation, distribution, advertisement, sale and use of food, drugs, cosmetics, chemicals/detergents, medical devices and all drinks including packaged and bottled water. NAFDAC took over all the functions of the FDAC, but not its bureaucracy. The 1993 decree was amended by Decree No 19 of 1999 (Federal Government of Nigeria, 1999a) to include unwholesome foods (Akunyili, 2010). 


\subsubsection{Mode of Operation}

The chief executive officer, the Director-General, reports to a Governing Council made up of representatives from the food and drug industry, the Federal Ministry of Health, the Standard Organisation of Nigeria (SON), the National Institute of Pharmaceutical Research and Development (NIPRD), the National Drug Law Enforcement Agency (NDLEA), and four members of the public, one of whom serves as the Chairman of the Council. The Council meets at least once every quarter to deliberate on policy issues. The Director-General is in charge of the day-to-day running of the Agency.

NAFDAC has 9 directorates:

1. Finance and Accounts;

2. Planning, Research and Statistics;

3. Establishment and Inspection;

4. Administration and Human Resources;

5. Narcotics and Controlled Substances;

6. Regulatory and Registration;

7. Ports Inspections;

8. Enforcement; and

9. Laboratory Services.

Each directorate is headed by a director who reports to the DirectorGeneral. In addition to the corporate headquarters and operation headquarters, NAFDAC has offices in 24 out of Nigeria's 36 states and four laboratory complexes.

\subsection{Application of Dependent Variable}

Performance is the dependent variable for this research. Although the performance of public sector organisations can be assessed through multiple parameters, I have focused the assessment of performance in this study on outputs. Therefore the focus is not on outcomes or impacts but on 
the extent to which a public sector organisation has achieved its predetermined goals with regards to outputs, given a set level of inputs.

In assessing the performance of SON and NAFDAC, I had identified, in Chapter 3, the key performance indicator to be used in assessing regulatory quality to be prevalence. Therefore since the mandate of SON is to reduce the prevalence of counterfeit goods, and that of NAFDAC is to reduce the prevalence of counterfeit drugs, what are the current levels of prevalence for both? I have relied on a variety of sources to assess the prevalence rates for counterfeit goods and drugs in order to get a sense of the actual performance of SON and NAFDAC.

\section{$\underline{\mathrm{SON}}$}

As at November $2010,60-80 \%$ of goods in Nigeria were estimated to be counterfeit (Next, 2009) and $75 \%$ of textiles sold in Nigeria were reported to be counterfeit (Radio Netherlands Worldwide Internet, 2010). In my interview with the Director-General on 8 October, 2011, he explained that $95 \%$ of the light bulbs in the Nigerian market are substandard. Consequently, they only last for 20 hours, instead of the standard lifespan of 4,000 hours. He also confirmed to a newspaper that $90 \%$ of the contents of seized containers at the nation's ports contain fake and adulterated goods (Sun, 2011).

It is apparent therefore that there is a serious problem with counterfeit and substandard goods in Nigeria and, as at November 2010, the problem was reported to be getting worse, rather than better (Next, 2010). However, in 2012, SON reported a $25 \%$ reduction in the prevalence of substandard products in the market (Guardian, 2012).

\section{$\underline{\text { NAFDAC }}$}

In 2003, the National Institute of Pharmaceutical Research and Development reported that $80 \%$ of drugs on sale in Lagos, Nigeria's commercial capital, 
were fake (International Anti-counterfeiting Coalition, undated). Generally, the incidence of fake drugs is reported to have reduced from $41 \%$ in 2002, through to $16 \%$ in 2006, to 10\% in 2011 (Akunyili, 2010, p. xvii; Chika, et al., 2011, p.1). In opinion ratings in Nigeria, NAFDAC was rated to be the most effective government agency in Nigeria for 3 years in a row (NOI Polls, 2007, 2008 and 2009). The United Nations Office on Drugs and Crime has also rated Nigeria as West Africa's most effective drug control country, and commended the work of NAFDAC (This Day, 2009).

While it is difficult to show the comparative performance of SON and NAFDAC in tabular form, I believe that the narrative above gives a clear picture of the differences in performance between the two organisations. NAFDAC has dramatically reduced the prevalence of fake drugs over a period of 10 years, while SON has just embarked on the improvement journey. In terms of the inputs used to achieve this performance, I will show later in this chapter that the level of government input per capita is the same for both organisations.

\subsection{Application of Explanatory Variables}

The explanatory variables for this research consist of external and internal factors. I will start the discussion of the explanatory variables in this case study by first assessing the internal factors at organisational level (such as good leadership), before assessing the application of factors external to the organisation (such as strong political and policy support). In parts, the discussion of the internal factors will, by necessity, allude to the external factors prevailing at the material time. However, a separate section on external factors will still be elaborated for clarity and consistency. 


\subsubsection{Internal Factors}

The internal factors for this study are leadership, management, technical capacity and public support. These were previously defined in Chapter 1 of this study.

\section{Leadership}

The Standards Organisation of Nigeria Act, 1990 does not specify any particular qualification for a person to be appointed the Director-General of SON. The Director-General is appointed at the pleasure of the President and previous post-holders have largely been viewed as "docile, ineffective and silent as a barrage of substandard products come into the country on a daily basis" (Nigerian Tribune, 2010). SON, under previous leaderships were seen to have either abandoned its responsibilities or simply been overwhelmed by them (This Day, 2009a). A new Director-General was appointed in 2011 and there are indications that he plans to be more effective than his predecessors (Vanguard, 2011; This Day, 2011c). This was also the opinion of Hawa Keri of NAFDAC in my interview with her on 28 June, 2011.

In my interview with the new Director-General, Dr J. Odumodu, on 8 October 2011, he confirmed that he was not given any specific mandate upon his appointment. It was a simple matter that the tenure of the previous Director-General had formally expired nearly two years ago, although he remained in office because nobody had asked him to leave. $\mathrm{Dr}$ Odumodu became aware of this fact and found a way to bring his curriculum vitae to the attention of the President. The President considered his resume alongside those of existing SON directors and decided to appoint him on the basis that it was better to bring in someone from outside SON. This sequence of activities has led to insinuations that Dr Odumodu actively lobbied to be appointed into the position, although this is difficult to prove, and is not always a bad thing even if it were true.

As Dr. Odumodu was not given any specific mandate on his appointment, it is unlikely that the government had any clear expectations of improvement following his appointment. Dr Odumodu posited that the Federal 
Government did not know how bad things were in SON and neither did he. This is surprising given that the press has been highly critical of SON and anybody that lives in Nigeria knows that the country is awash with fake and substandard goods (The News, 2011; Nigerian Tribune, 2011a). However, because he is "naturally a self- starter", the new Director-General has set himself and his organisation a six-point agenda:

1. Build SON capacity, including changing the current 40:60 technical to administrative capacity ratio to 90:10; and ensuring that $\mathrm{SON}$ has accredited labs that can test for conformity;

2. Aggressively ensure strict enforcement of standards;

3. Improve the competitiveness of locally manufactured products by enforcing zero tolerance for substandard goods;

4. Consumer engagement and protection;

5. Strong media collaboration; and

6. Collaboration with major marketers.

This six-point agenda, in addition to corruption, give a good pointer about what SON has not been doing well to date. Dr Odumodu was, until his appointment, the Managing Director and Chief Executive Office of the international pharmaceutical firm May and Baker and is seen by most to have done a good job while he held that post.

The process for appointing the immediate past Director-General of NAFDAC, the comparator organisation for SON in this case study, could not have been more different. Section 9 (1) of Decree 15 of 1993 that established NAFDAC says that "there shall be appointed for the agency by the President Commander in Chief of the Armed Forces, on the recommendation of the Minister, a Director-General who shall be a person with good knowledge of pharmacy, food and drug".

Dora Akunyili, a professor of pharmacy, was working at the Petroleum Trust Fund when she was diagnosed with pancreatic disease. Her office approved $£ 17,000$ for her treatment in the United Kingdom. $£ 12,000$ was to cover the cost of surgery and $£ 5,000$ was for her living expenses. After undergoing a series of tests, it turned out that her condition did not require surgery. To the consternation of the staff at the Cromwell Hospital in London, she requested that the $£ 12,000$ earmarked for the surgery should be 
refunded to her agency. According to staff in the hospital, this was unheard of for a Nigerian. They would usually want the hospital to inflate the cost of treatment and pocket the difference between the real cost and the cost to government. Her boss at the Petroleum Trust Fund, General Buhari, who himself is known to be incorruptible, wrote her a letter of commendation expressing his delight that there are still Nigerians with personal integrity. Akunyili's atypical act eventually came to the attention of then President Obasanjo who at the time was looking for somebody of integrity to lead NAFDAC. The President offered her the NAFDAC job with a clear directive to go and clean up NAFDAC and curb the menace of fake and substandard drugs in the country (Akunyili, 2010, p.xxxvii). My interviews with Akunyili and Obasanjo in 2011 confirmed these.

Dora Akunyili's appointment was made at some personal and political cost to the president. Various politicians saw NAFDAC as a goldmine. Indeed, in my interview with Akunyili on 21 January 2011, she said "If the DG of NAFDAC wants $£ 5$ million or $\$ 5$ million every day of the 365 days in year, he or she will get it very easily." The Senate President wanted his brother to have the job but President Obasanjo refused, and stood firm against any threats and attempts at intimidation. In my interview with her, Akunyili stated that she believed that the various threats of impeachment from the Senate during the presidency of President Obasanjo were attributable to his refusal to appoint the Senate President's brother. He offered her his unwavering support and protection and never once interfered adversely in her job. In providing an insight into how leaders of organisations are chosen in Nigeria, Akunyili said in her interview with me on 21 January, 2011:

Most of the time, I am sorry to say, most Nigerians are not interested in who can do the job. It's about who will I put there to benefit me? And that is why whatever people say about Obasanjo, that man has many positive qualities that are un-Nigerian.

Opinion is divided about how effective Akunyili's predecessor at NAFDAC was. The general perception was that NAFDAC was generally ineffective under the leadership of Professor Osuide who headed the organisation before Dora Akunyili (Pogoson, 2009, p.9). In my interview with her on 21 
January, 2011, Akunyili described the state of NAFDAC when she first arrived at the organisation:

It was a mess. There was nothing. You are talking about scientific equipment but what about the offices? Everything was so dilapidated that you wondered how they existed. They didn't have good offices and office equipment. The laboratories were in shambles. There was so much confusion. The sophisticated equipment I met was not even fixed. Everything was just lying on the floor. Total unseriousness (sic). People were not trained. So we started on all fronts.

In her memoires of her time at NAFDAC, Akunyili similarly painted a damning picture of the organisation that she met when she first went to NAFDAC:

When I assumed office in April 2001, I was faced with the arduous task of reactivating a food and drug regulatory environment which had failed for over three decades, resulting in a crisis situation characterised by massive copying of original brands of drugs and other regulated products. Every part of the organisation was dysfunctional, from the staff to the laws and the facilities.

However, some people give Professor Osuide credit for setting the foundations upon which Akunyili rebuilt NAFDAC. They point, for instance to his efforts to build the capacity of staff and to regulate the practice of herbal medicine in Nigeria, and blame his ineffectiveness on the fact that he operated under a military government that constrained his freedom to act (Pogoson, 2009, p.10). My opinion is that, whatever efforts Professor Osuide made in terms of staff training and the regulation of herbal medicine, the incidence of fake drugs rose steadily under his watch. Since NAFDAC's raison d'être is to curb the menace of fake and substandard drugs, his leadership could not have been said to be effective. The reasons advanced, including military rule, only go to explain the ineffectiveness, not to disprove it. 
Although she stated in my interview with her that she did not know anything about NAFDAC at the time she was appointed, Akunyili had had a very personal encounter with the dangers of fake drugs. Her sister had died prematurely from the use of fake insulin in 1988, an incidence that "brought the acutely painful message of counterfeit medicine squarely home to me" (Akunyili, 2010, p.v).

With the clear mandate that she had been given, the personal zeal to avoid deaths like her sister's and the express backing of the President, Dora Akunyili set about her task in NADFAC by adopting four main strategies:

- Restructuring and reorganising NAFDAC, including staff reorientation, reorganisation and motivation, restructuring the organisation, improving laboratory capacity and improving physical infrastructure;

- Improving the operations of NAFDAC, including introducing new regulations, controlling clinical trials, targeting the sources of counterfeit medicines, strengthening surveillance at all ports of entry, destroying fake drugs already in circulation and quality assurance of locally manufactured products;

- Engaging Stakeholders, including the use of public enlightenment campaigns, workshops and seminars, engaging with manufactures, engaging with all relevant stakeholders including the media, the courts, the Standards Organisation of Nigeria and the Nigeria Customs Service; and

- Enforcing discipline, including naming and shaming offenders, blacklisting offending companies, seizure and destruction of fake and substandard drugs, and the jailing of offenders.

It is clear that the SON six-point agenda of 2011 draws very heavily from NAFDAC's four strategies of ten years before, particularly as the DirectorGeneral of SON is an official member of the NAFDAC Board. This point is important for discussion in Chapter 7 of this research (Cross-case Analysis) in terms of replication and building a critical mass for atypical performance.

In my interview with Akunyili, she was very clear that the most important factor that affects organisational performance is organisational leadership. “Even if you don't know the President of Nigeria and don't know what his 
face looks like, you can still transform an organisation. The President's support will ease pressure on you and make it easier and people will not fight you too much." This view is consistent with that of Nuhu Ribadu, former head of EFCC, in Chapter 4 of this research that the leader of the organisation can bring about positive change even in the absence of clear political support. However, Akunyili was more cognisant of the importance of clear political backing from the very top, and the enabling environment that it provides for the determined leader, than Ribadu appeared to me to be.

Akunyili was also of the view that the most important person-specification for an aspirant to the position of the Director-General of NAFDAC is incorruptibility. The second is knowledge about food and drugs. Again, these views are consistent with Ribadu's in the previous chapter about the need for the leader of the organisation to be incorruptible, and be seen to be so, and to fully understand their subject.

The change of government in Nigeria in 2007 had no adverse effect on the work of NAFDAC. Although Dora Akunyili was still the head of NAFDAC at the time that President Yar'adua came into office, she had been the campaign manager for his election and was one of his closest allies. That gave her the sort of protection that Nuhu Ribadu did not appear to enjoy after Obasanjo left office.

In 2011, Dora Akunyili left the Goodluck Jonathan-led government. Like Ribadu, she chose to enter active politics and run for elective office by contesting for the Senate. Like Ribadu, she lost.

Professor Akunyili was replaced at NAFDAC by Dr. Paul Orhii, who was said to have been recommended by the former Minister of Justice and Attorney General of the Federation under President Yar'adua. Michael Aondoakaa, who hails from the same state as Paul Orhii, is blamed by many Nigerians with deliberately undermining Nigeria's anti-corruption efforts in his time as Attorney General, with Yar'adua's consent and encouragement. His recommending Paul Orhii for appointment as the Director-General of NAFDAC was therefore seen by many commentators at the time as another attempt to disable the organisation and promote corruption in the food and 
drugs sector. Mr Aondoakaa was the first person to be sacked when Goodluck Jonathan became President.

Being a neuro-pharmacologist and an attorney, the Pharmaceutical Society of Nigeria criticised Paul Orhii's appointment on the basis that he knew very little about pharmacy, food and drugs (Pogoson, 2009, p.22). They felt that the federal government had breached the provisions of Section 9(1) of the NAFDAC Decree in that Paul Orhii was not "a person with good knowledge of pharmacy, food and drug".

Regardless of this initial criticism, Paul Orhii has built on Dora Akunyili's work, particularly by introducing technological innovations in the fight against fake drugs. NAFDAC remains a strong organisation, although Paul Orhii's quieter leadership style has led some to form the perception that NAFDAC's effectiveness has reduced since Dora Akunyili left the organisation. However, as at the time of writing in November 2011, NAFDAC continues to perform well and the incidence of counterfeit drugs continues to fall.

\section{Management}

As in the previous chapter, in discussing management I will address the issues of funding, recruitment processes, performance management, human resource management, reward and discipline, staff motivation, and pay and conditions of service.

\section{Funding}

It is tortuously difficult to get a true picture of the total amount of inputs provided to each organisation. There is almost always a disparity between the figures held in the Budget Office of the Federation, the Office of the Accountant General of the Federation, and in the Finance departments of the organisations themselves. The difficulty with relying on the figures from the Budget Office is that it captures the funds that have been appropriated, 
rather than what has been actually released to the organisation (often significantly less). Conversely, relying on the figures held by the organisation itself generally carries a risk that the organisation may have under-reported what it actually received, particularly if a proportion of it has been top-sliced for the purposes of corruption.

The federal budget generally underperforms, as the annual budget that should be implemented from January each year is often not passed until June of the budget year. This means that ministries, departments and agencies often only have six months to utilise the annual budgetary provisions. As all agencies suffer the same difficulties in this regard, I will be relying on the appropriated figures published by the Budget Office of the Federation. For the purposes of this study, the level of budgetary appropriation is a good indicator of the importance that the government places on the agency. Of course, there are other factors such as the ability of the agency to mobilise funds, historical performance against previous appropriations, and significant new capital projects, such as building a new corporate headquarters, that may necessitate a large one-off budgetary provision. However, the level of budgetary provision is a good indicator of government support, as well as the organisation's ability to mobilise resources.

Between 2008 and 2011, the following amounts (in Nigerian Naira) were appropriated for SON and NAFDAC:

\begin{tabular}{|l|l|l|l|l|}
\hline Organisation & 2008 & 2009 & 2010 & 2011 \\
\hline SON & $949,631,705$ & $1,069,378,319$ & $2,055,025,732$ & $1,867,487,778$ \\
\hline NAFDAC & $1,698,834,770$ & $1,558,182,205$ & $2,245,000,000$ & $3,666,183,448$ \\
\hline
\end{tabular}

Table 8: Budgetary Appropriations to SON and NAFDAC ${ }^{26}$

${ }^{26}$ Source Budget Office of the Federation website: www.budgetoffice.gov.ng , accessed on 22 August 2011. 
Table 8 above shows that NAFDAC has consistently been appropriated about $30 \%$ more money than SON has been, except for 2010 when the appropriations for both organisations were very similar, and 2011 when the NAFDAC appropriation represents nearly doubled what was appropriated for SON. However, in 2010, the appropriation for SON was significantly more than SON's 2008 figures and was nearly double that in 2011.

Readers unfamiliar with Nigeria may also be surprised to note that getting information about the exact staff strength of organisations in Nigeria is a difficult endeavour. The NAFDAC website claims that the organisation has more than 3,000 officers. However, given that the website is still showing Professor Dora Akunyili as the Director-General, as at 13 November, 2011, more than two years after she left the post, makes it inadvisable to rely on.27

In my interview with Mr. J.A. Aina, NAFDAC's Assistant Director of Administration and Human Resources, he put NAFDAC's current staff strength at "about 1,570". In my interview with the Director-General of SON on 10 October, 2011, he confirmed that SON's total staff strength is currently 1,055 . This means that NAFDAC has almost exactly a third more staff than SON.

Given that NAFDAC has a third more staff and receives a third more funding than $\mathrm{SON}$, it is arguable that the level of government input per capita is the same for both organisations.

The Director-General of SON confirmed in my meeting with him on 10 October 2011 that SON additionally generates internal revenue of N1.6 billion per annum. On the other hand, an independent system study of NAFDAC conducted by the ICPC confirms that NAFDAC generated a total of N15.5 billion in internally-generated revenue from 2006 to 2010 (Daily Trust, 2011). This represents an average of N3.9 billion per annum, more than double the amount generated by SON. The Director-General of SON believes that his organisation generates much more than it declares but loses a sizeable amount of it to staff corruption. He confirmed that he has also compared SON's tariffs with those of NAFDAC and found that both were at

${ }^{27}$ http://www.nafdacnigeria.org/dg.html, accessed from the internet on 7 November, 2011. 
par, save for the cost of registration which is higher at NAFDAC. SON is in the process of upwardly reviewing the registration fees it charges to its clients.

The use of internally generated revenue is a current and contentious issue. A strict interpretation of Section 162 of the Constitution of the Federal Republic of Nigeria, 1999 (Federal Government of Nigeria, 1999) makes it mandatory for all government ministries, departments and agencies to remit all the revenue that they generate into a central pool called "the Federation Account". From this account, funds are then distributed to all tiers and arms of government. However, various agencies, including NAFDAC, claim to have received Presidential dispensation to retain that part of the revenue collected that offsets the cost of collecting it. The ICPC is of the opinion that any such dispensation granted to any agency is in conflict with the supreme law of the land, the Constitution, and is therefore illegal and void. Mr Chukwu Obiora, the Deputy Director of Budget at NAFDAC argued in his interview with me that removing NAFDAC's ability to keep part of the revenue that it generates will cripple the organisation overnight. Given that NAFDAC only receives a fraction of the annual budget that it bids for from the federal government, the federal budget for each year is not passed until halfway into the budget year, and not all of what is appropriated is actually received, the agency relies heavily on its internally-generated revenue in order to maintain its operations. Removing the ability to retain a portion of the revenue will also dampen staff morale and remove the incentive to perform well, as most of the organisation's performance incentives are funded from internally-generated revenue. Like NAFDAC, SON keeps part of its internally generated revenue. However, it is worth pointing out that internally revenue has the potential to promote corruption, since it is generally not open to audit by the Auditor General of the Federation, not being part of the budget appropriated for the organisation.

In addition to budgetary allocation and internally-generated revenue, NAFDAC also receives significant donor support for its activities. It has received support from the Global Alliance for Improved Nutrition, the United Nations Children's Fund (UNICEF), the United Kingdom's Department for International Development (DFID) and the World Bank. Hawa Keri, Director, Establishment Inspectorate Directorate at NAFDAC 
confirmed to me during my interview with her that NAFDAC actively seeks the collaboration of development partners and also responds positively to suitable proposals from donors. Crucially, she added that donors have confidence in NAFDAC and know that their support will not be misused or diverted to an unintended purpose. Unfortunately, it was not possible to quantify the total value of the support in monetary terms. SON has received hardly any donor support to date and this is something that the new Director-General wants to address and remedy.

\section{$\underline{\text { Recruitment Process }}$}

Before the appointment of the current Director-General, recruitment into SON had been opaque and lacking in transparency. The process was often for people who had access to the former Director-General to approach him seeking employment and for him to unilaterally offer them employment. The current Director-General stated in his interview with me on 10 October, 2011, that he had had to "regularise" the appointments of more than 300 officers whose appointments did not follow due process. Under Dr Odumodu, SON now uses an open and transparent process to recruit staff. On 21 October, 2011, SON placed an advertisement on page 16 of Nigeria's This Day newspaper seeking a range of technical staff. The advertisement was also placed on the internet at www.dragnetnigeria.com/son, which I accessed on 30 October, 2011.

Since the time of Akunyili in 2001, NAFDAC has been recruiting its staff through an open, transparent and merit-based process. Advertisements are placed in various Nigerian newspapers and reputable firms of human resource consultants are engaged to assist with the short-listing of the usually large response to advertisements. Short-listed candidates are invited to sit aptitude tests and then have to be interviewed by an independent panel. In one case, the Kewalram-Chanrai Group, a foreign company with a presence in Nigeria volunteered to assist NAFDAC with the aptitude tests for more than 10,000 candidates, at no cost to the Agency (Akunyili, 2010, p.47). 
NAFDAC has 9 directorates, each headed by a director. "The appointment of these directors was carried out without the usual recourse to political considerations that often characterises appointments in Nigeria's public service" (Pogoson, 2009, p.16). The exercise was based entirely on merit and followed examinations and panel interviews headed by two university Vice Chancellors.

\section{$\underline{\text { Performance Management }}$}

Officially, both SON and NAFDAC use the same Annual Performance Evaluation and Review (APER) process used in the mainstream federal civil service. On its own, this is not a very effective process for evaluating performance or encouraging enterprise and innovation. The Federal Government of Nigeria admits that the civil service does not have an effective performance management system (Federal Government of Nigeria, 2008, p.63).

In an interview with me on 21 January, 2011, Mr Babaji, Assistant Chief Administrative Office at SON admitted that the APER process has been grossly abused at SON and is not an effective performance management tool. He states that SON has recently adopted a policy to tackle the abuse of the APER process, which for the first time includes specifying tasks and introducing targets.

Although NAFDAC uses the same APER process, each directorate has a very clear process of managing staff performance. Akunyili describes the performance management system that she put in place at NAFDAC thus:

There was constant staff performance evaluation, to ensure commitment and effectiveness. To check staff tardiness and absenteeism, we introduced clocking registers in every unit. The measure drastically reduced the frequency of excuses of "going to the bank", a common practice by public service employees in Nigeria. Any staff member found to be violating timekeeping policies was 
issued a query and disciplined appropriately. Two members of staff were dismissed for habitual tardiness. Delaying the treatment of any document for more than 48 hours attracted a query, which could lead to suspension if unjustified. Memos were issued to that effect. To enforce this directive, my Special Assistant performed routine checks on mails and file movements, (Akunyili, 2010, p.49).

In my interview with Mrs Hawa Keri, Director, Establishment Inspectorate Directorate at NAFDAC on 28 June 2011, she outlined how she manages the performance of her staff and confirmed that "other departments do the same". Officers are first set very clear performance targets. Each senior member of staff has to appear before the Director-General and the entire management team to report on progress in their respective areas. Following the report,

Questions will be asked and reports have to be verifiable. If you say you have done five inspections, it's not a piece of paper I want. I want evidence that it has been done. That is one way, and this is ongoing and continuous [...] You will tell them again what you want, with next steps. At the end of each meeting, an email goes out to all attendees and they have to provide updates every week. We created a reminder chart of what needs to be done on a weekly basis and reassess progress monthly [...] We also do surveys just to be sure how we are doing.

In NADFAC, hard work, dedication and transparency are rewarded with letters of commendation personally signed by the Director-General, promotions, and exposure to further training. Whistle-blowing was encouraged and those that exposed importers and producers of fake products were appropriately rewarded. This motivated officers to go out of their way to seek out offenders. More interestingly, members of staff were 
encouraged to blow the whistle on each other where an officer has behaved inappropriately or corruptly. Where the facts are proven, the whistle-blower is rewarded. This system was operated without fear or favour and the Director-General had to dismiss her own brother-in-law who worked at the agency when he was found to have demanded a bribe from an importer of unregistered food products (Akunyili, 2010, p.48). She says of the action she took:

His dismissal created a lot of problems for me amongst my in-laws, but it effectively put everybody on notice that there would be no sacred cows in the war against counterfeit medicines in Nigeria.

It is easy to fail to grasp the monumental cultural and sociological implications of an African woman dismissing her husband's younger brother, given the strongly patrimonial nature of most African societies. This singular act must have sent shockwaves throughout the organisation and beyond.

\section{Pay and Conditions of Service}

Both SON and NAFDAC operate the Consolidated Research and Allied Institutions Salary Structure (CONRAISS) set out by National Salaries, Incomes and Wages Commission. Circular SWC/S/04/VIII/354 of 14 December 2010 (Federal Government of Nigeria, 2010) sets the consolidated salary scales applicable to SON and NAFDAC. The Director-General of SON in my interview with him on 10 October 2011 confirms that SON personnel earn the same as those of NAFDAC and that pay is not a factor in performance. Both organisations earn more than the mainstream civil service. Table 9 below illustrates the difference between CONRAISS (paid to NAFDAC and SON) and the Consolidated Public Service Salary Structure (CONPSS) paid to mainstream civil servants in ministries as set out in Circular number SWC/S/04/VIII/298 on 1 July 2010 by the Salaries and Wages Commission. It shows that both organisations earn considerably more than civil servants in ministries, except at the very top of the career 
positions (Director) where the mainstream civil servants earn a bit more. It is noteworthy that, given the very high salaries paid to Permanent Secretaries, Director successfully agitated for an increase in their own salaries. This effectively doubled their salaries as compared to those of Deputy Directors immediately below them who earn N2,186,877 at step 1.

\begin{tabular}{|l|l|l|}
\hline Level & CONRAISS & CONPSS \\
\hline (SON/ NAFDAC) & \\
\hline $\begin{array}{l}\text { Middle management - } \\
\text { Assistant Director, Step 1 }\end{array}$ & $2,247,854$ & 655,384 \\
\hline $\begin{array}{l}\text { Senior management - } \\
\text { Director, Step 1 }\end{array}$ & $4,047,462$ & $1,285,018$ \\
\hline
\end{tabular}

Table 9: Comparison of Pay between SON/NAFDAC and mainstream Civil Service $\mathrm{e}^{28}$

SON and NAFDAC are on the same pay scales as set for them by the National Salaries, Incomes and Wages Commission. This would suggest that, although they both earn more than mainstream civil servants, pay is not an issue in their differentiated performance.

\section{Technical Capacity}

The use of modern technology is very limited at SON. According to its Director General, forty years after its establishment in 1971, the organization does not have a single laboratory. The new Director-General said in his interview with me on 10 October 2010 that technological awareness in the organization is currently so low, and the office environment so unsuitable, that it would be inappropriate of him to put in place a simple computer network at SON's head office at this point in time. He plans to move the head office of the organization to another location and gradually commence the introduction of modern technology. All documentation in SON is still

\footnotetext{
${ }^{28}$ Source: Circulars SWC/S/04/VII/354 and SWC/S/04/VIII/298 of the National Salaries, Incomes and Wages Commission.
} 
managed with the use of paper files and very few officers have access to a computer. Discussions on 21 January 2011 with a junior member of staff who did not want to be identified suggested that the computers on the tables of senior staff were merely decorative as most of them did not even know how to switch them on. SON does not have an Information Technology department and the new Director-General described his efforts at introducing modern technology as "setting up from Ground Zero."

NAFDAC uses technology much more effectively. The head of the Information Technology Unit was brought in from the private sector eight years ago to support the Agency and its staff. Mr Olufemi Balogun, Assistant Chief Computer Analyst and head of the NAFDAC Information Technology Unit set out his key roles in an interview with me on 28 June 2011 as:

- Maintain systems;

- Advise management on available technological advancements affecting the Agency's operations;

- Monitor Information Technology projects;

- Operate a helpdesk to respond to user requirements; and

- Support the training of staff in technology usage.

NAFDAC has a Laboratory Information Management System which manages the work flow in the laboratory. There are plans to migrate this system to a web-based system that will integrate quality assurance and quality control instruments with requisite standards and variables. NAFDAC also has an automated product registration system.

The World Health Organisation has donated a Computer Aided Medical System to NAFDAC to help with the regulation of drugs and ensure that they comply with good manufacturing practice.

Perhaps most significantly, NAFDAC has a technology called True Scan. This technology enables NAFDAC to scan a product and instantly verify 
whether or not it is genuine. It works by NAFDAC preloading the footprints of a drug into the machine's memory. When the drug is tested in the field, it will fail the test if it does not match the preloaded footprint. Additionally, NAFDAC encourages manufacturers to include serial numbers for their drugs which are revealed to the patient when she scratches off a foil covering a part of the drug packet. The patient can then send the serial number by short messaging service to NAFDAC for confirmation that the drug is genuine. I tried this service with a malaria tablet on 10 November 2011 and promptly received a text message on my mobile phone from NAFDAC that the drug is genuine. The message included the NAFDAC registration number of the drug (an anti-malarial called Lonart), some advice to sleep under mosquito nets in order to avoid future episodes of malaria, and the telephone number of a NAFDAC helpdesk.

Additionally, the NAFDAC finance system runs the SAGE 500 software, and there is a computerized pay and personnel management system. Promotion examinations are done online and this has forced all staff to improve their computer skills. Currently, there is one computer to every two members of staff. It is expected that every member of staff will have their own computer by the end of 2012 .

\section{Public Support}

In the NOI/ Gallup polls on the Perception of Effectiveness, Confidence and Corruption in Government Institutions and Agencies in Nigeria, 2007, 2008 and 2009, NAFDAC has consistently been perceived to be Nigeria's most effective public organization. Over the period, $74 \%$ of respondents perceived NAFDAC to be effective. This survey was based on top-of-themind organisations and SON did not feature as one of the organisations on the top of peoples' minds. 
While the press has been generous in offering complimentary remarks about NAFDAC's efforts (Akunyili, 2010, pp. 411-416), it had, until recently, generally made very damning remarks about SON's lack of effectiveness (This Day, 2009a; Nigerian Tribune, 2010).

Akunyili credits the press for the turnaround in NAFDAC. In her interview with me on 21 January 2011, she said:

The press played a central role in our overall NAFDAC activities [...] Our very first activities were carried out because we were stampeded by the press [...] Week after week, they harassed me and that was why we quickly put up our first workshop for pure water manufacturers. So we actually started faster than usual because of the press [...] Again, I found that the counterfeit drug dealers were more afraid of the press than the courts. When we take cases to court, the cases stay for 10 years until the judges are transferred or die, or the evidence is lost. But once the names of these criminals are published on the pages of newspapers, announced on the radio or shown on television, nobody has ever contested it [...] I would say that the Nigerian press is an asset to this country. They have gone further than the press in other West African countries.

An entire chapter in Akunyili's book (2010, pp. 77-108) is devoted to how NAFDAC engaged with stakeholders, including the media. In his interview with me on 10 October, 2011, even the Director-General of SON admitted that NAFDAC has been very good at managing publicity, media relations and its image. He said: 
One of the reasons that NAFDAC appears to succeed is that they know how to communicate. SON has been very poor at communicating its activities, so even its modest achievements are not known by the public.

It is in this regard that Consumer Engagement and Strong Media Collaboration are highlighted as part of the six-point agenda of the new Director-General of SON. Already, there is evidence that SON has started to engage with the press in the way that NAFDAC does. Newspaper headlines now include "Odumodu to unfold agenda for SON" (Vanguard, 2011), "FG begins total clampdown on fake products" (This Day, 2011c) and "Standardising SON" (Tribune, 2011). While it could be argued that these articles were planted in the press by SON, it still appears to be a deliberate effort to get the public on the side of the organisation and raise the profile of its activities. In addition to this media activity, SON is working with the Consumer Protection Council to set up market desks where the quality of goods can be tested. The Director-General regrets the low patronage of these desks and blames it on the current lack of public confidence in SON's abilities, competence and integrity.

Finally, after 7 years as the Director-General of NAFDAC, Dora Akuniyili was appointed the Minister of Information and Communication for the Federal Republic of Nigeria in 2008. When the government's intention to make her a minister was announced, but before portfolios were assigned, many Nigerians had expected her to be appointed the Minister for Health. The fact that the government appointed her to the Ministry of Information and Communication is indicative of how well she had used the media at NAFDAC. 


\subsubsection{External Factors}

External factors are those extraneous factors that can affect organisational performance, but which the organisation has little or no control over. The external factors to be considered in this case study are political and policy support, institutional factors and clear expectations from political masters.

\section{Political and Policy Considerations}

In introducing this section, a brief history of the political context since Nigeria became a democracy again would be helpful. Nigeria emerged from military rule in 1999. Olusegun Obasanjo became President and served two terms of four years in office, from 1999 to 2007. It was under President Obasanjo that all the atypical performers in this dissertation started to perform atypically. It was President Obasanjo that appointed the leaders that brought about atypical performance in EFCC, NAFDAC and FIRS and created the enabling environment for them to perform. In 2007 when he left office, President Yar'adua came into power. Yar'adua and those around him felt that Obasanjo had railroaded a lot of the reforms through and had sometimes bypassed due process. Yar'adua developed a mantra of "rule of law" to ensure that things followed laid down rules. This had the effect of slowing down many initiatives started under President Obasanjo, and attempting to reverse some, like the EFCC prosecution of political office holders. President Yar'adua died unexpectedly in 2009 and his deputy Goodluck Jonathan became President of Nigeria. President Jonathan is expected to be in power until 2015.

Both Dora Akunyili and President Obasanjo confirmed in their respective interviews with me that President Obasanjo provided the NAFDAC leadership with all the support that it required, sometimes at great personal political cost to the President. They also confirmed that there was never an occasion on which the President adversely influenced the work of NAFDAC for party political considerations.

Akunyili believed that Obasanjo was motivated by patriotism in his support for the NAFDAC and other reforms. However, when I put the question directly to President Obasanjo, he explained that he had become an "anti- 
corruption crusader" by the time he came into office in 1999. Interestingly, he drew an anti-corruption thread through the case study organisations for this study, in that theft from the public treasury is corruption (EFCC and ICPC), dealing in counterfeit and substandard pharmaceuticals and goods is corruption (NAFDAC) and pocketing tax payments rather than paying them into the treasury is corruption (FIRS and NCS). Therefore, the first bill that he put to the National Assembly was the ICPC bill, a bill that he drafted himself, in his own hand.

I asked President Obasanjo why he appointed a strong leader for NAFDAC but not for SON. His response was that the business of NAFDAC was more serious than that of SON. According to him, "fighting fake drugs all over the country takes much more than just setting standards". He also said that he could not reform every single agency overnight and reminded me that public service reform is a highly political process. In my view, it appears to have more to do with the timing of the vacancies that appeared in the organisations. As Nigeria does not have a culture of removing chief executives for underperformance, it is only when the tenure of the incumbent runs out that the government uses the opportunity to engage a better leader. My argument is buttressed by the fact that President Obasanjo came into power in 1999 but did not seek out and appoint Akunyili until 2001 when the tenure of her predecessor ran out. Also, although Dr Akanya, the former Director-General of SON, was widely seen as ineffective, Obasanjo did not remove him while he was President. It was only when his tenure expired that President Jonathan replaced him with the new DirectorGeneral, Dr. Odumodu.

On offering Akunyili the NAFDAC job, President Obasanjo stated in his interview with me that he asked her what she needed to get the job done.

She said, 'I have nothing in case they kill me'. She said that she didn't have a house to leave to her children if she were to lose her life on the job. I had to look for a way to get her a house, not through government.

The point that the President took away that anxiety of Akunyili in this way is a very important indicator of strong political backing, but can also be seen 
to be a distortion of the normal appointment and remuneration process. In their interviews with me, Akunyili (and EFCC's Ribadu) had listed incorruptibility as being the primary ingredient that a leader must have to succeed in a dysfunctional environment. They were both of the opinion that you did not need to be financially secure to be incorruptible. However, my interview with President Obasanjo provided a useful insight about how Akunyili's pressing financial anxiety (not owning a house) was removed by the President, leaving her less susceptible to the temptation to engage in corrupt activities. This fact was not mentioned by Akunyili in my interview with her. EFCC's Ribadu was promoted three times in three years by Obasanjo. That would also have had the effect of easing some of the financial worries he may have had.

Additionally, the Federal government put in place three new policies that greatly facilitated the work of NAFDAC:

- The outright ban on the importation of drugs and other regulated products through land borders;

- The designation of Calabar and Apapa sea ports, and Murtala Mohammed and Mallam Aminu Kano International Airports as exclusive ports of entry for the importation of drugs and pharmaceutical raw materials; and

- Release of shipping and cargo manifests by the Nigeria Ports Authority, Shipping Lines and Airlines to NAFDAC inspectors, (www.nigeriafirst.org/printer_315.shtml).

The Federal government did not give this sort of specific support to SON, although there is no evidence that $\mathrm{SON}$ requested such support.

Since its inception in 1993, NAFDAC has put in place several regulations and strengthened its penalties and sanctions. The new SON DirectorGeneral feels that SON's current laws were sufficient to have cleaned up the system. The problem he identifies is an absence of allies within SON. He says "People within the system already knew how to frustrate all reforms." 


\section{Institutional Factors}

The institutional factors surrounding the work of SON and NAFDAC are different. While most Nigerians would see counterfeit electronics or designer goods as a victimless crime, they would take a very dim view about counterfeit pharmaceuticals. It is for this reason that counterfeit pharmaceuticals are immediately destroyed when seized, but other counterfeit goods when seized are auctioned. Naturally, when they are auctioned, the very same goods find their way back into the market.

This is an important point when considering NAFDAC's success in reducing the prevalence of fake and substandard drugs in the country. It is true that through strong leadership, good management practices, the use of technology and good public relations, NAFDAC has made a big difference in the fight against fake and substandard drugs. However, this singular institutional practice of destroying fake drugs when seized, rather than auctioning them off for re-entry into the market, is undoubtedly a major factor in the reduction in the prevalence of fake drugs in Nigeria. It is arguable too that the rising prevalence of substandard goods (overseen by $\mathrm{SON}$ ) is because those goods are auctioned when they are seized.

Corruption is another key institutional factor. While the anti-corruption agency, EFCC, has praised NAFDAC's efforts (The Nation, 2008, p.A6), SON's Dr Odumodu decried the corruption within his agency. There were frequent allegations of seized goods suddenly being released by the former Director-General, presumably after having received gratification. Akunyili buttresses this point in her book when she narrated how SON released a consignment of sugar that was still undergoing quality tests in NAFDAC's laboratories (Akunyili, 2010, p. 99). NAFDAC has made strenuous efforts to tackle official corruption (including Akunyili sacking her own brother-inlaw for bribery) but SON appears to have been trapped by that constraint and is just beginning to tackle the menace. 
Finally, the role of industry is an important consideration. The legitimate pharmaceutical industry (i.e., those engaged in the manufacture or distribution of genuine drugs) in Nigeria had started to suffer as a result Nigeria's reputation as a purveyor of fake and substandard drugs. Many West African countries had banned the importation of drugs from Nigeria. The legitimate pharmaceutical industry had, therefore, started to mount pressure on the government to address the issues of fake drugs. Similar pressure was not apparent in other types of manufacture: those that $\mathrm{SON}$ is responsible for.

\section{Clarity of Expectations}

President Obasanjo's charge to Akunyili when he was appointing her was very clear. "I want you to go and clean up NAFDAC". He had sought her out after she had been recommended to him based on her unusual act of honesty in returning unspent medical funds, and he had set her a clear task and given her all the support needed to actualize it. However, President Obasanjo did not appear to have much interest in the work of SON. He never sacked the ineffective leader it had and never demanded anything particularly from the organisation. Continuing this tradition, President Jonathan did not give the new leader of SON any specific mandate upon his appointment.

The EFCC case study in Chapter 4 suggested that it is visible performance first that gets the attention of political leaders who then set more challenging goals. President Obasanjo confirmed this to me in his interview with him on 29 October. However, a distinction is to be made in that the President was very clear about what he wanted and the sort of leader he wanted before he appointed Akunyili. It is a matter for conjecture whether he would have removed Akunyili if she had failed to perform, like countless other leaders in Nigeria fail to, or whether he would simply have ignored NADFAC until Akunyili's tenure expired when he would try and get another good leader. Although President Obasanjo rationalised his support to EFCC, NAFDAC and FIRS as part of his anti-corruption campaign, it is 
not clear whether this consistent thread through the three organizations was thought out a priori or ex post facto.

\subsection{Demand}

In this research, I have adopted the Sullivan and Sheffrin (2003) definition of demand: an informed desire for something, backed by the ability and willingness to pay for it. In Chapter 4, I started to explore the extent to which demand was a factor in the performance of specific organisations. Therefore, was there an informed desire to bring about performance improvement, backed by the capability to achieve that performance improvement and a willingness to deploy that capability to achieve it? We will now try to answer this question in the contexts of SON and NAFDAC using the Indicators for Testing the Existence of Demand that I had set out in Chapter 3.

\section{$\underline{\mathrm{SON}}$}

In my fieldwork and the review of secondary data on SON, I could not find evidence that there was an informed desire by politicians to bring about performance improvement, backed by the capability to do so and a willingness to deploy that capacity. In my interview with President Obasanjo on 29 October, 2011, he was somewhat dismissive of the role of SON, which he described as "just setting standards", and the current Director-General confirmed that he was not given any specific mandate when he was appointed. Similarly, it was not apparent that there was demand for better regulation from the private sector or donors present in Nigeria. Instead, manufacturers in Nigeria advocated for import prohibition to protect local industries, rather than better regulation. There was no evidence of demand from citizens, many of whom may want the option of obtaining substandard, but cheaper, goods.

However, there was some pressure from the global campaign against counterfeiting, and regular and strong pressure from the media. However, these pressures do not qualify to be termed demand since there was no obvious capability to bring about the desired improvement and no evidence of an attempt to develop that capacity. The improvements currently being 
undertaken by the Director-General of SON appears to be motivated solely by his own professional antecedents as a "self-starter". Sensibly, in my view, the Director-General is focusing on those areas that have safety implications and are likely to resonate with the public. These are iron rods (to forestall cases of building collapse), vehicle brake pads (to avoid road accidents), and electronics (to avoid personal injury to users). The reforms in SON are still at an early stage, but the Director-General of SON is officially on the board of NAFDAC and it is likely that some initiatives that made NAFDAC successful are beginning to filter into SON.

\section{$\underline{\text { NAFDAC }}$}

For NAFDAC, there was clearly government demand. President Obasanjo headhunted and appointed someone who had demonstrated incorruptibility. He viewed the trade in fake drugs as corruption, and had been an anticorruption campaigner even before he became president. He carried the focus on anticorruption through to his presidency. Akunyili herself had lost her sister to fake drugs and there was, therefore, perhaps a personal desire to fight the menace, in addition to a professional desire to do a good job.

There was demand from the private sector, as pharmaceuticals coming out of Nigeria were banned by neighbouring countries. It was not apparent that there was demand by donors in Nigeria, although they willingly provided support to the effort to rid the country of fake drugs. There was strong pressure from the international community (e.g., United Nations bodies, such as the World Health Organisation), the media (particularly when children die from fake drugs) and citizens. The informed desire to bring about change was backed by a capability to bring it about (strong political support, provision of resources and strengthening of legislation), and a clear willingness on the part of the political and organisational leadership to deploy that capability.

In summary, there appears to be clear evidence of demand in NAFDAC but not in SON. 


\subsection{Methodology}

Table 9, below, compares the data gathering activities employed in completing this case study with the methodological plan outlined in Chapter 3 of this study. While I have made strenuous efforts to be faithful to all planned activities, it has not always been possible, or necessary, to do so. The reforms that happened in NAFDAC are already the subject of two detailed books by the chief executive that led the reforms. Therefore, most of my efforts have been focused on triangulating information and updating the data since the new Director-General came into post. Additionally, during the course of the case study, a new regime has come into SON that effectively admitted the inadequacies of the past and has started moving the organisation forward in the direction of the reforms that took place at NAFDAC.

\section{Interviews}

The list of people interviewed is shown below. All interviews were conducted in Abuja, Nigeria (unless otherwise shown), over a 14-month period from January 2011 to March, 2012.

\begin{tabular}{|c|c|c|c|}
\hline $\begin{array}{l}\text { Planned } \\
\text { Respondents }\end{array}$ & Actual Respondents & Lines of Enquiry & Tool \\
\hline $\begin{array}{l}\text { Relevant } \\
\text { Ministers and } \\
\text { Top Politicians }\end{array}$ & 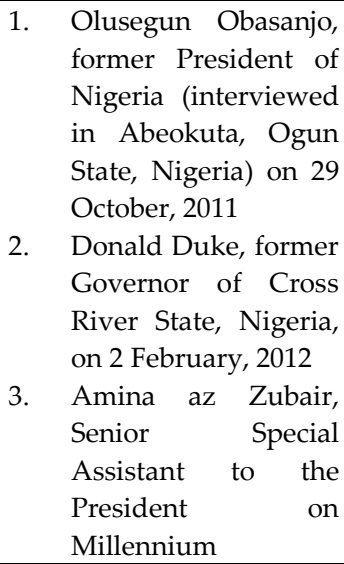 & $\begin{array}{l}\text { - The source of pressure/ } \\
\text { demand for change/ } \\
\text { political environment } \\
\text { prior to reforms } \\
\text { - If and when a decision for } \\
\text { improvement was made, } \\
\text { why and by whom. } \\
\text { How the conditions for } \\
\text { improvement came into } \\
\text { play. } \\
\text { Hierarchy of conditions }\end{array}$ & $\begin{array}{l}\text { Semi- } \\
\text { structured } \\
\text { interviews }\end{array}$ \\
\hline
\end{tabular}




\begin{tabular}{|c|c|c|c|}
\hline & $\begin{array}{l}\text { Development Goals } \\
\text { and member of the } \\
\text { Presidential } \\
\text { Economic Team on, } \\
20 \text { April, } 2011 \\
\text { 4. } \\
\text { Special Assistant to } \\
\text { the President on } \\
\text { Media and Publicity, } \\
\text { (interviewed on } \\
\text { British Airways flight } \\
\text { from Abuja, Nigeria } \\
\text { to London, UK) on } 18 \\
\text { November, 2011 } \\
\text { Frank and Nweke, } \\
\text { Jnr., Former Minister } \\
\text { for Information } \\
\text { Communications, on } \\
2 \text { February, 2010. }\end{array}$ & & \\
\hline $\begin{array}{l}\text { Past and } \\
\text { present Chief } \\
\text { Executives }\end{array}$ & $\begin{array}{ll}\text { 6. } & \begin{array}{l}\text { Dora } \\
\text { former }\end{array} \text { Director- } \\
\text { General of NAFDAC } \\
\text { on 21 January, } 2011 . \\
\text { 7. Joseph Odumodu, } \\
\text { Director-General, } \\
\text { SON, on } 10 \text { October, } \\
\text { 2011. }\end{array}$ & $\begin{array}{l}\text { - The source of pressure/ } \\
\text { demand for change. } \\
\text { If and when a decision for } \\
\text { improvement was made, } \\
\text { why and by whom. } \\
\text { - How the conditions for } \\
\text { improvement came into } \\
\text { play. } \\
\text { - Hierarchy of conditions }\end{array}$ & $\begin{array}{l}\text { Semi- } \\
\text { structured } \\
\text { interviews }\end{array}$ \\
\hline
\end{tabular}




\begin{tabular}{|c|c|c|c|}
\hline $\begin{array}{l}\text { Officers- Low, } \\
\text { Middle and } \\
\text { Senior } \\
\text { Management } \\
\text { Level }\end{array}$ & 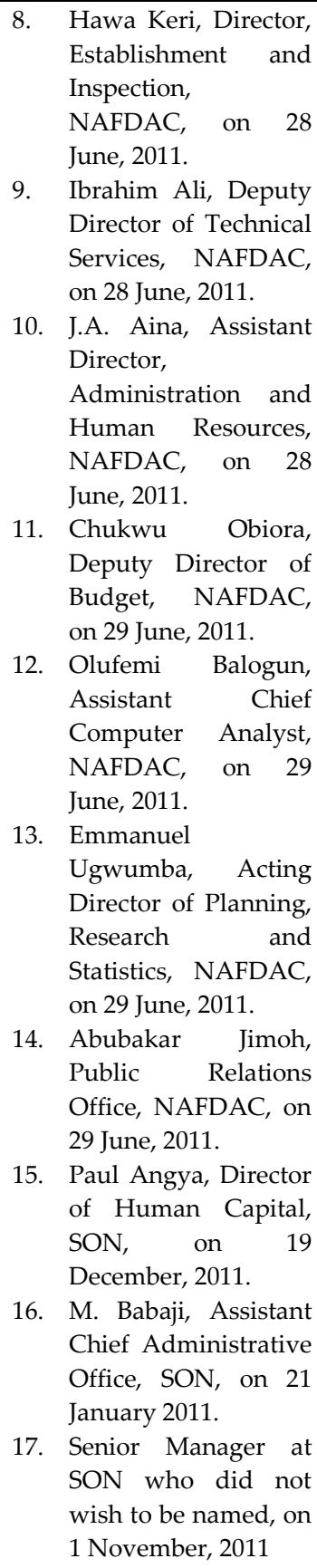 & $\begin{array}{llr}\text { - } & \text { External and Internal } \\
& \text { Factors affecting } \\
\text { performance } & \\
\text { - } & \text { Internal organisational } \\
& \text { and } \quad \text { management } \\
\text { arrangements }\end{array}$ & $\begin{array}{l}\text { Semi- } \\
\text { structured } \\
\text { interviews }\end{array}$ \\
\hline
\end{tabular}




\begin{tabular}{|c|c|c|c|}
\hline $\begin{array}{l}\text { Civil Society/ } \\
\text { Media } \\
\text { Representatives }\end{array}$ & $\begin{array}{l}\text { 18. Jibrin Ibrahim, } \\
\text { Executive Director, } \\
\text { Centre for } \\
\text { Democracy and } \\
\text { Development, on } 5 \\
\text { September, 2011 } \\
\text { 19. Soji Apampa, } \\
\text { Director, Convention } \\
\text { on Business Integrity, } \\
\text { on 2 October, 2011. }\end{array}$ & $\begin{array}{l}\text { - The source of pressure/ } \\
\text { demand for change } \\
\text { - } \quad \text { Hierarchy of conditions }\end{array}$ & $\begin{array}{l}\text { Semi- } \\
\text { structured } \\
\text { interviews }\end{array}$ \\
\hline $\begin{array}{l}\text { Private sector } \\
\text { representatives }\end{array}$ & $\begin{array}{ll}\text { 20. } & \text { Ken Ukoha, } \\
& \text { Secretariat President, } \\
& \text { National Association } \\
\text { of Nigerian Traders, } & \text { on 23 March 2012. } \\
\text { 21. Convention on } \\
\text { Business Integrity }\end{array}$ & $\begin{array}{llr} & \text { The source } & \text { of } \\
\text { pressure/demand } & \text { for } \\
\text { change } & \\
\text { - } & \text { Hierarchy of factors }\end{array}$ & $\begin{array}{l}\text { Semi- } \\
\text { structured } \\
\text { interviews }\end{array}$ \\
\hline Donors & 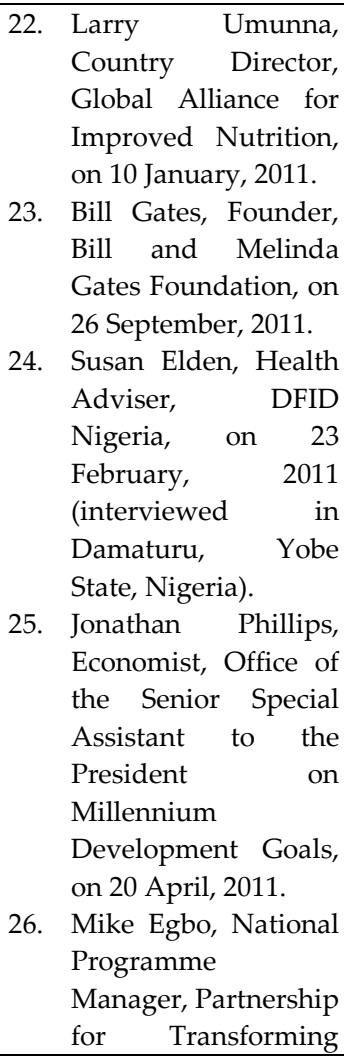 & $\begin{array}{l}\text { Source of pressure/ } \\
\text { demand for change and } \\
\text { role of donors } \\
\text { - Hierarchy of conditions }\end{array}$ & $\begin{array}{l}\text { Exploratory } \\
\text { and semi- } \\
\text { structured } \\
\text { interviews }\end{array}$ \\
\hline
\end{tabular}




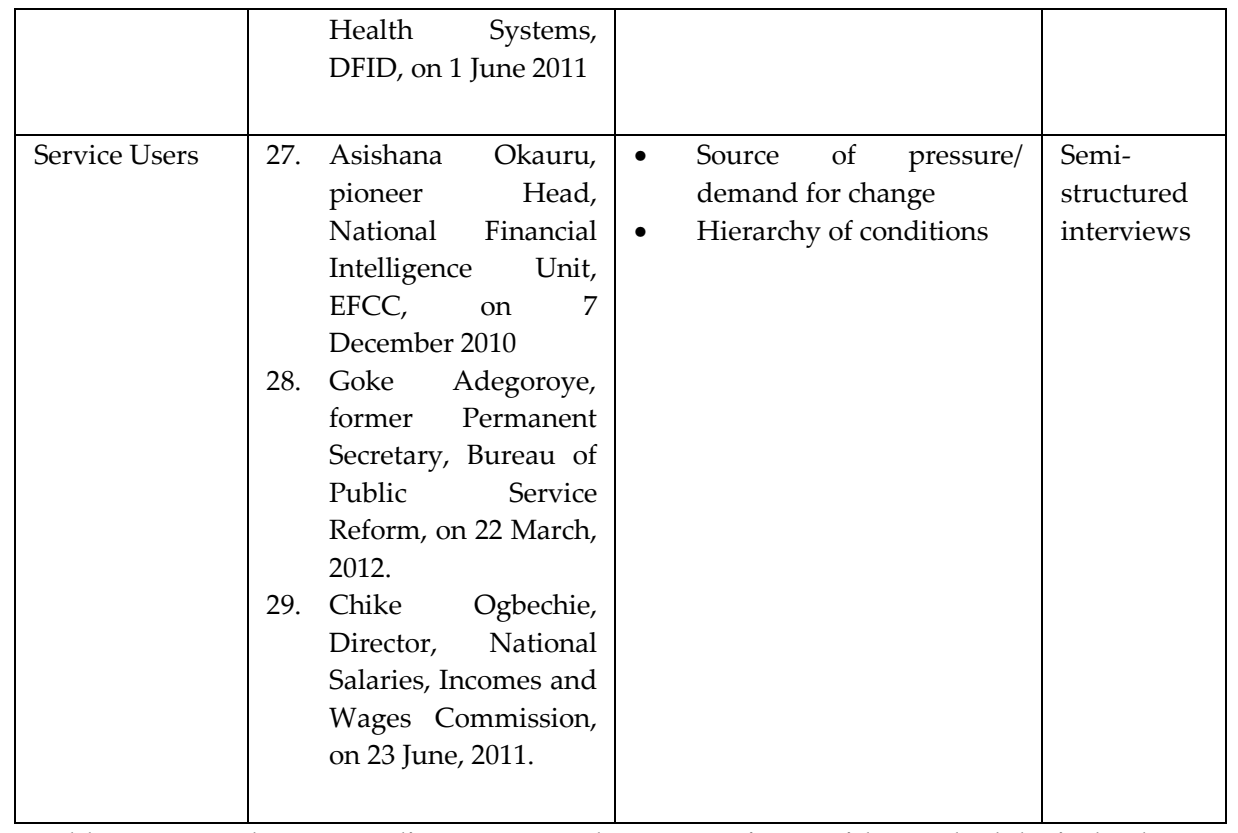

Table 10: Regulatory Quality Case Study: Comparison with Methodological Plan SON/NAFDAC

\subsection{Conclusions}

In this chapter, I have continued the process of theory-building that started from my literature review chapter through to the case study on anticorruption in the previous chapter. The case study in this chapter are of two organizations that existed well before performance improvements started to occur, and which could therefore not be said to have been deliberately designed to be atypical.

The external and internal factors that explain performance bear close similarities with those identified in the previous case studies on anticorruption in Chapter 4, although they differ significantly in some respects. The developing theory that atypical performance was triggered by a desire for change, backed by the ability to bring about that change appears still to 
be holding. In the case of EFCC, it appears that a combination of internal and external factors came together at the right time to bring about the change, and that both the political and organizational leadership was able to make the change required. While many of the same internal and external factors are present in NAFDAC, the pressure for change did not seem to have been any stronger when the reform of NAFDAC started that it had been for many years before. There was perhaps more immediacy with EFCC, with Nigeria having been blacklisted by the Financial Action Task Force, seeking debt relief from the Paris Club, Nigerian businesses suffering and Nigerian citizens subjected to humiliation abroad, all at the same time.

One important thread that is beginning to emerge through both case studies though, is the role of an activist political leader coupled with that of an activist organizational leader. This thread gained prominence after my interview with President Obasanjo who presided over the initiation of atypical performance in each organisation. We will explore this theme again in the next chapter.

The last case study on Revenue Administration, in the next chapter, will continue the process of theory-building. We will assess the extent to which the developing theory holds, is modified or must be abandoned. This will be particularly interesting, as the circumstances surrounding the reform of the Federal Inland Revenue Service appears, on the face of it, to differ significantly from those of EFCC and NAFDAC. 


\section{Chapter 6 Revenue Administration: Giving To Caesar}

The avoidance of taxes is the only intellectual pursuit that carries any reward, (Keynes, date unknown).

Unfortunately, the rich hate paying taxes even more than the poor. ${ }^{29}$

This chapter continues the search for the answer to the main research question posed in this study: How and why are certain public sector organisations able to achieve atypical performance in dysfunctional environments? It studies two organisations: the Federal Inland Revenue Service (FIRS) and the Nigeria Customs Service (NCS), and starts with an abstract that sets out the key issues addressed in the case study. As with previous case studies on Anticorruption and Regulatory Quality, it briefly outlines the background and history of each organisation, explores the application of explanatory variables to the research question, explains the findings and further develops the theory of demand.

\subsection{Abstract}

This case study presents an interesting variation to the two previous case studies on anticorruption and revenue administration. In the first respect, it could be argued that EFCC and NAFDAC succeed because they receive public support for the kinds of work that they do - fighting corruption and reducing the prevalence of fake pharmaceutical products, issues that tend to resonate with the public. These are different from ICPC that focuses on

\footnotetext{
${ }^{29}$ Ataa Lawrence Ikpebe, Comptroller of Customs, Enforcement, interview with me on 22 March, 2012.
} 
bureaucratic, rather than political, corruption, and SON that is perceived by some to be dealing with victimless crimes, such as the counterfeiting of designer goods (Gallup, 2005). FIRS and NCS work in a field where public support, globally and historically, tends not to be strong: the collection of taxes (Soest, 2003, p.33).

This case study is also an interesting variation with regards to the dependent variable for this study - performance, as measured by the ability of revenue administration agencies to meet the targets set for them by government. Based on perception surveys conducted in Nigeria (NOI Polls, 2007, 2008 and 2009) NCS was perceived to be a more effective organization than FIRS with $50 \%$ of respondents rating it as effective, as compared to $38 \%$ for FIRS. However, on ascertaining actual performance at the start of the research in 2009, it was apparent that FIRS was meeting and exceeding its revenue collection targets (the performance measure used in this research) and that NCS had not done so for 3 years in a row. FIRS was therefore selected as the atypical performer to be compared with NCS, the typical performer. Interestingly, in the course of the study, NCS has started to exceed its targets by appearing to adopt some of the measures to which FIRS attributes its success, such as incentivising performance and deploying technology in its operations. Nevertheless, NCS has not yet maintained this performance over a sufficiently long period of time to warrant it being described as an atypical performer. To qualify as an atypical performer in this research, the organisation needs to have delivered on its mandate for at least 8 years.

Lastly, on the face of it, neither organisation could be described as having a charismatic leader who has brought about atypical performance largely through the force of their own character, in the way that the initiators of the changes in EFCC and NAFDAC could. Instead, the reforms at FIRS have been described as a 'silent revolution' (Tell, 2011).

Overall, the case study continues to support the developing proposition that atypical performance was triggered by a pressure for change, backed the willingness and ability to bring about that change. 


\subsection{Introduction}

There is no commonly accepted definition for the term 'revenue administration'. The terms is often used interchangeably with tax administration, but connotes a wider function that the administration of taxes. Depending on the definition of the word tax that is considered, tax administration will often focus on the administration of personal and corporate income tax, and may not cover levies, excise duties and other charges (Buyonge, 2008; Prichard and Leonard, 2010; Kloeden, 2011). For the purposes of this research, public sector revenue administration can simply be defined as the process through which taxes, duties and other charges accruable to the state are billed for, collected, accounted for and managed.

Many authors view the capacity of the state to raise revenue as a fundamental determinant of state capacity. Indeed, some authors go as far as using it as the key determinant of the capability of the state in general (Soest, 2009, p.61; Prichard and Leonard, 2010, p.654). Without going into the debate about the accuracy of this proposition, it is apparent that this case study is an important one in trying to answer my research question. It can be argued that if a revenue administration agency in a weak governance state is able to deliver on its mandate and meet its targets, wider reforms are likely to be possible. For instance, Prichard and Leonard (2010, p.670) found a positive and significant relationship between taxation and broader improvements in state capacity, but their results also suggest that that relationship is not universal or automatic.

The availability of oil in parts of the developing world has led to a huge body of literature on 'resource curse', a notion that mineral dependent states have a tendency to fail to harness their resources for national development and can even be harmed by those mineral resources (Shaxson, 2007, p. 1123). The fact that Nigeria has oil resources means that many Nigerians do not feel the need to pay taxes. This makes the effort to collect non-oil revenue arduous, a situation that is compounded by the feeling that what revenue the government collects does not translate into public goods and 
improvements in the lives of citizens. ${ }^{30}$ An IMF study of Nigeria found that between 1970 (the start of the oil boom) and 2000, Nigeria earned about $\$ 350$ billion, but income per capita fell and equality worsened sharply. It stated that in $1970,36 \%$ of the population was poor, but that this had risen to nearly 70\% in 2000 (Shaxson, 2007, p. 1124)

Nigeria has long recognized the fragility of its mono-commodity economy (Federal Government of Nigeria, 2004c) and has often stated the need to diversify its economy away from oil and reduce its reliance on the proceeds from that commodity. However, Shaxson notes that:

[...] whereas politicians in oil-rich countries routinely proclaim the need to diversify away from dependence on natural resources, the trend tends to be in the other direction, because of the damage that mineral dependence inflicts on other economic sectors (Shaxson, 2007, p.1124).

He further points out that in Angola, Equatorial Guinea and Nigeria, oil and gas accounts for between 95 and 99 percent of exports.

However, the rising capacity of the Nigerian government to collect non-oil revenue is suggestive of a level of seriousness beyond that suggested by Shaxson. FIRS and NCS are the main revenue administration agencies in Nigeria. There are, of course, many sources of revenue open to government, such as income from licences, fees, service provision, fines and charges, and these are collected by various other agencies of government, such as the Passport Office, the Nigeria Immigration Service, various lands departments and the national electricity company. However, the income from FIRS and NCS constitutes the largest share of tax income in the country. FIRS and NCS are similar in their remit, in that the primary function of both organisations is to collect and manage revenue. NCS, of course, has a wider remit which extends to the control of importation and exportation of goods. However, this study is limited to NCS's capabilities as

\footnotetext{
${ }^{30}$ My interview with Emmanuel Obeta, Director of Corporate Communications, FIRS, on 23 December 2011.
} 
a revenue administration agency. I will now seek to understand how both organisations work.

\subsection{The Nigeria Customs Service}

\subsubsection{Brief History of the NCS}

The NCS has existed in one form or another for more than 100 years. The first formalisation of the function of a customs service can be traced back to 1891 when the British colonial administration in Nigeria appointed the first Director-General of Customs to collect Inland Revenue in the Niger Coast Protectorate. The Department of Customs and Excise first emerged in 1922 and the first Comptroller General of Customs and Excise was appointed. The department had two divisions, one to focus on the collection of import and excise duties and the other to focus on the prevention of smuggling. In 1977, the first major reorganisation of the Customs and Excise Department was undertaken and this resulted in the structuring of the department into five main directorates:

- Tariff and Trade;

- Enforcement;

- Investigation;

- Inspection; and

- Economic Relations, Research and Planning.

In 1985, the Department of Customs and Excise was removed from the Federal Ministry of Finance, its traditional home, and moved to the Federal Ministry of Internal Affairs. This led to the creation of the Customs, Immigration and Prisons Board, through Decree No. 14 of 1986. In 1992, the Department of Customs and Excise was transferred back to the Federal Ministry of Finance and was given paramilitary status. Therefore, officers of the service are allowed to bear arms and their salaries were benchmarked with those of other paramilitary organisations like the Nigeria Police Force. It was renamed the Nigeria Customs Service and given a supervisory board. The Board of the Nigerian Customs Service has the following members: 
- Minister of Finance (Chairman);

- Comptroller General of Customs (Vice Chairman);

- A representative of the Federal Ministry of Commerce;

- A representative of the Federal Ministry of Transport;

- A representative of the Federal Ministry of Industries;

- A representative of the Federal Ministry of Finance, in addition to the Chairman;

- A representative of the National Universities Commission;

- Chairman of the Federal Inland Revenue Service;

- Serving Deputy Comptrollers General of Customs;

- The Legal Adviser of the NCS; and

- The Secretary to the Board.

It is curious that the board includes a representative of the National Universities Commission. I was unable to find any explanation for the reasoning behind that inclusion. Interestingly also, the Chairman of the Federal Inland Revenue Service, the comparator organisation for this study is a member of the board. This is similar to the case of SON and NAFDAC in Chapter 5 of this study where the Director-General of SON sits on the NAFDAC board.

The work of NCS is regulated by the Customs and Excise Management Act (CEMA), Cap 45, Laws of the Federation of Nigeria, 2004 (Federal Government of Nigeria, 2004d). This vests the legal authority on all customs matters in the NCS. CEMA is supported by various other regulations, such as those prohibiting the dumping of substandard goods in Nigeria. As at March 2012, the House of Representatives in Nigeria is currently processing a bill to repeal CEMA and consolidate all the enabling laws guiding the operations of the NCS into a single reference document, instead of the current situation where the Service's legal authority is scattered in multiple enactments. The bill has passed the second reading in the House.

According to its website ${ }^{31}$, the vision of the Service for itself is:

\footnotetext{
${ }^{31}$ http://www.customs.gov.ng/About/mission_statement.php, accessed on 12 March 2012.
} 
- To excel in the efficient and timely collection of and accounting for revenue;

- Implement and advise on government trade and fiscal policies;

- Promote trade facilitation; and

- Protect Nigerian society.

It is important to note that the first vision that the Service has for its self is the efficient and timely collection and accounting for revenue. The introductory statement to CEMA describes the Act as "An act to regulate the management and collection of duties of customs and excise, and for purposes ancillary thereto." It is therefore clear that in the mind of the government and that of the Service, the NCS is, first and foremost, a revenue management organisation.

NCS is perceived by many to be a corrupt organisation. In the NOI Polls survey of 2008, NCS was rated to be the third most corrupt organisation, better only than the power company and the police (NOI Polls, 2008, p.15). Also in a 2010 survey of businesses, 35\% of businesses claimed to have paid a bribe to NCS officials in order to clear their goods through customs (NBS/EFCC, 2009, p.4). If these allegations are correct, it would suggest that NCS may be under-reporting the level of revenue that it generates. A World Bank report on Nigeria's restrictive trade policies blames the corruption of the NCS on the long list of banned goods which facilitates smuggling and rent-seeking by government officials (Business Day, 2010). The list of banned items is so long that many Nigerians find it safer to presume that all importation is banned. In fact, there are 24 categories of banned items on the Import Prohibition List, including food, cement, medicines, soaps and detergents, textile, footwear, fruit juice, mosquito repellent coils, glass bottles, vehicles older than 15 years and even ballpoint pens. ${ }^{32}$ However, most of the banned items are freely sold in markets and even on the streets.

\footnotetext{
32 Accessed from the NCS Website on 2 March 2012 at http://www.customs.gov.ng/ProhibitionList/import.php.
} 


\subsubsection{Functions of NCS}

As earlier stated, the functions of the NCS are scattered in various legislations and regulations, hence the current effort by the legislature to harmonise it into a single reference document. However, the NCS website ${ }^{33}$ lists its statutory functions as:

- Collection of, and accounting for, revenue;

- Preventing the smuggling of goods;

- Security;

- Generating Statistics for planning and budgetary purposes;

- Monitoring foreign exchange utilisation;

- Engaging in research into, planning, and enforcement, of fiscal policies of government;

- Processing shipping manifests;

- Licensing and registration of customs agents;

- Registration and designation of banks that collect custom revenues on behalf of NCS; and

- Collaboration with other government agencies in all approved ports and borders.

Again, it is instructive that revenue administration is the first function listed. Discussing the organisational design of customs in sub-Saharan Africa, Creck Buyonge points out that customs services are required to carry out mandates which go beyond revenue collection, in an environment that emphasises the revenue function over any other function (Buyonge, 2008, p.53).

Section 5 of CEMA says that the NCS is subject to the direction of the Minister of Finance. However, in undertaking its revenue function, the Act says that the Minister

[...] shall not give any direction, order or instruction in respect of any particular person which would have the effect of requiring the Board to increase or decrease any

\footnotetext{
${ }^{33}$ http://www.customs.gov.ng/Statutory/functions.php, accessed on 2 March, 2012.
} 
assessment of duty made or to be made or any relief given or to be given or to defer the collection of any duty or judgment debt due, or which would have the effect of initiating, forbidding the initiation of, withdrawing or altering the normal course of any proceedings whether civil or criminal relating either to the recovery of any duty or to any offence under the customs and excise laws (CEMA, 2004).

Therefore, the NCS enjoys some level of autonomy with regards to its revenue functions. This is not unusual in Anglophone Africa where many customs services now have organisational semi-autonomy. This is a different structure from that which operates in many Francophone African countries where the customs service still operates as part of the mainstream civil service (Buyonge, 2008, p.54).

\subsubsection{Mode of Operation}

Apart from the Office of the Comptroller General, the NCS currently has five main departments, each headed by a Deputy Comptroller General:

- Human Resources and Development;

- Enforcement, Investigation and Inspection;

- Tariff and Trade;

- Strategic Research and Policy; and

- Corporate and Support Services.

The Tariff and Trade Department is the main revenue administration arm of the NCS. This research therefore focuses more closely on its operations than on other departments.

Section 8 of CEMA gives customs officers the same powers, authorities and privileges as are given by law to police officers. They therefore have powers of arrest, interrogation and detention, and are allowed to bear arms. 
CEMA contains very stiff penalties. For instance concealing imported good with the intention of evading duty is punishable with 5 years imprisonment, without the option of a fine (Section 47). The same penalty is prescribed for exporting goods without paying the required duty (Section 64). However, it is not often that this penalty is imposed. Indeed, none of those I interviewed could remember a single instance where someone had been convicted and sentenced to five years imprisonment without the option of a fine.

Section 46 of CEMA says that any goods imported contrary to prohibition (i.e., goods on the Import Prohibition List) shall be forfeited. SON, from the case study in Chapter 5, blames this provision in CEMA for the proliferation of substandard goods in Nigeria. When substandard goods are forfeited, they are often publicly auctioned. This means that they find their way into the Nigerian market. Revenue from auctioned goods does not go into the coffers of NCS as part of its revenue figures but is paid into the federal government's Consolidated Revenue Fund almost in the form of a fine. When seized, substandard pharmaceuticals are not auctioned but are immediately destroyed instead.

NCS has a total staff strength of 16,000 officers as at February 2012 (Abdullahi, 2012), and recruitment is done openly though advertisements and an apparently-transparent selection process. However, a customs officer that did not wish to be named confided in me that senior officers are often given quotas during recruitment exercises. This enables them to bring in family members, friends and people from the same state as them. This practice is not unusual in the Nigerian public service.

Having briefly outlined the history and nature of the NCS, I will now set out the history and nature of a similar organisation (on the revenue side), the FIRS, before undertaking a comparative analysis of both organisations against research propositions. 


\subsection{The Federal Inland Revenue Service (FIRS)}

\subsubsection{Brief History of FIRS}

Similar to that of NCS, the history of FIRS dates back to the colonial era. Early in the $20^{\text {th }}$ Century, an Inland Revenue Department of the colonial administration was established as a unitary body to cover the Anglophone West African countries of Nigeria, Ghana, Gambia and Sierra Leone. The first Commissioner of Income Tax was appointed in 1940 to oversee revenue administration in those four countries, under the Nigerian Income Tax Ordinance of 1940.

In 1943, the Nigerian Inland Revenue Department was created and, in 1961, after Nigeria attained its independence from Britain, its name was changed to the Federal Board of Internal Revenue (FBIR). FBIR was established under Section 4 of the Companies and Income Tax Act, No. 22 of 1961, as a department in the Federal Ministry of Finance. This was the position until 1993 when the Finance (Miscellaneous Taxation Provisions) Act No. 3 of 1993 established the Federal Inland Revenue Service as the operational arm of FBIR. The 1993 Act, for the first time, also created the office of the Executive Chairman of the Board.

According to Mr Achillies Amawhe, FIRS Director of Internal Affairs, who joined the Service in 1982 (nearly 30 years ago), "FIRS was a typical government organisation that was part of the civil service. It was a closed shop. Not many people knew what it was about." ${ }^{34}$ The Nigerian tax system has witnessed four major reforms in the last 30 years (Tell, 2011, p. 5). The efforts to reform FIRS started in 1978 with the introduction of Withholding Tax which diversified the tax base from Personal Income Tax which had almost been the sole focus of the Service. In 1992, a study group was set up to review the Nigerian tax system and recommend improvements. In the same year, the Federal Government also set up a study group on Indirect Taxation. The recommendations from these studies led to the introduction of Value Added Tax in 1993 to further diversify the revenue base.

\footnotetext{
${ }^{34}$ My interview with Achillies Amawhe, Director of Internal Affairs, FIRS, on 22 December, 2012.
} 
However, the major transformative reform of FIRS started in 2002 during President Olusegun Obasanjo's first term in office. Both the National Economic Empowerment and Development Strategy (NEEDS) of 2004 (Federal Government of Nigeria, 2004c) and the UK Department for International Development's (DFID's) Drivers of Change analysis of Nigeria (Heymans and Pycroft, 2005) had identified over-dependence on oil as one of the major barriers to economic growth in Nigeria. In advance of these, the Federal Government had inaugurated a study group in August 2002 to undertake a massive overhaul of the entire tax system in Nigeria.

The Terms of Reference for the Study Group on the Review of the Nigerian Tax System, inaugurated by the Minister of Finance on 6 August 2002, were quite comprehensive. The group was to:

a. Review all aspects of the Nigerian Tax System and recommend improvements;

b. Review all tax legislations in Nigeria and recommend amendments where necessary;

c. Review all assessment and collection procedures, including payment procedures, objection and appeal procedure and court proceedings and recommend appropriate improvements;

d. Review the entire tax administration and recommend improvements in the structure for the whole country, as well as the administrative structures at the Federal, State and Local Government levels, with a view to enhancing performance and efficiency;

e. Consider and recommend the possibility of the grant of financial autonomy to the revenue authorities;

f. Review and recommend the jurisdiction and scope of tax authorities and the Federal, State and Local Government levels;

g. Examine and recommend the mode of financing revenue authorities to reflect constitutional provisions;

h. Assess the extent of implementation and the impact of the recommendations of the 1991 Study Group;

i. Consider international developments in taxation and recommend suitable adaptation in Nigerian circumstances;

j. Evaluate and confirm the desirability or otherwise of the retention of the portfolio of fiscal incentives enshrined in the tax laws; and 
k. Consider and recommend new taxes where necessary, with a view to significantly improving the overall tax system (Federal Government of Nigeria, 2003).

I asked Mr M.A.C. Dike, FIRS Director of Tax Policy and Secretary to the study group, why the government wanted to reform the tax system at that particular time. I asked whether it was as a result of pressure from donors to diversify the economy or as a result of a pressing financial need or some other reason. He said that it is general practice worldwide to periodically review the tax system for currency and adequacy of the legal and regulatory provisions, and that the last review had been done in 1992. This view is consistent with that of Mr Abdullahi Attah, Special Adviser to the Executive Chairman, who said that because tax is a dynamic subject, regular reform is part of its characteristics (Tell, 2011, p.5). However, "At the back of every tax reform is the need to raise more revenue." 35

In 2000, the Chartered Institute of Taxation of Nigeria had set up a committee to review taxes in Nigeria. Based on the findings of this committee, FIRS sent a memorandum to the Minister of Finance recommending that the tax system in the country should be reviewed. The Minister of Finance, an ex-World Bank Managing Director and Chairman of Nigeria's Economic Management Team, received the report of the 2002 Study Group in July 2003 and set up a working group comprising tax experts to review the report and propose a programme of reforms. An International Monetary Fund (IMF) mission at the same time also provided technical assistance to the Federal Government on the review of the overall state of tax administration in Nigeria and submitted its report to the Ministry of Finance in September 2004. The current Executive Chairman, Ifueko Omoigui-Okauru, was appointed in 2004 to ensure the implementation of agreed recommendations and drive through the necessary reforms of the service.

Describing the state of FIRS at the time, Amawhe said:

\footnotetext{
${ }^{35}$ My interview with M.A.C. Dike, Director of Tax Policy, FIRS, on 17 January, 2012.
} 
Our vision at that time was to be the most efficient organisation in the country but everything we did was antithetical to this. Everything we did was done manually. We didn't even know who the taxpayers were or where they were. You don't even have market segmentation. 70\% of our manpower consisted of support staff. We had security men who were blind. Training had been abandoned for more than 15 years and we had people that rose to become Assistant Directors without basic training in tax administration. Audit was not happening. There was no taxpayer education. Everything the study group saw was the opposite of efficiency.

Upon appointment, Omoigui-Okauru was asked by President Obasanjo to draw up a blueprint for the reform of FIRS and the Nigerian tax system, based on the findings of the 2002 study group, the 2003 working group of tax experts and the IMF report. The harmonisation of these various reports formed the basis of the first FIRS Modernisation Plan which OmoiguiOkauru was invited to present to the Federal Executive Council on 18 October 2004. This was an unprecedented move because no head of the revenue administration function in Nigeria had ever been invited to present to the Federal Executive Council, which is the highest policy-making body in the country. That Modernisation Plan, with updates and readjustments, is what is still being implemented in FIRS in 2012.

In 2007, FIRS was granted autonomy from the Federal Ministry of Finance through the Federal Inland Revenue Service Establishment Act of 2007. The preamble to the Act describes it as "An Act to provide for the establishment of the Federal Inland Revenue Service charged with powers of assessment, collection of, and accounting for revenues accruable to the Government of the Federation, and for related matters".

Section 3 of the FIRS Establishment Act of 2007 sets out the composition of the FIRS Board which supervises the Service. The Board consists of:

a. The Executive Chairman of the Service, who shall be experienced in taxation, to be appointed by the President, subject to the confirmation of the Senate; 
b. Six members with relevant qualifications and expertise who shall be appointed by the President to represent each of the six geo-political zones of Nigeria;

c. A representative of the Attorney General of the Federation;

d. The Governor of the Central Bank of Nigeria;

e. A representative of the Minister of Finance not below the rank of a Director;

f. The Chairman of the Revenue Mobilisation, Allocation and Fiscal Commission;

g. The Group Managing Director of the Nigerian National Petroleum Corporation;

h. The Comptroller General of the Nigerian Customs Service

i. The Registrar General of the Corporate Affairs Commission; and

j. The Chief Executive Officer of the National Planning Commission.

It is instructive that the Comptroller-General of Customs is on the Board of FIRS, just as the Executive Chairman of FIRS is on the board of the Nigerian Customs Service. I will return to this point later when I talk about the influence of successful reform efforts in one organisation on other similar organisations.

It is also worth noting that the Executive Chairman of FIRS is the Chairman of the FIRS Board, rather than the Minister of Finance, as is the case with NCS.

\subsubsection{Functions of FIRS}

Section 8 of the FIRS Establishment Act of 2007 sets out 20 functions for the Service. The Service is required inter alia to:

a. Assess persons including companies and enterprises chargeable with tax;

b. Assess, collect, account for and enforce payment of taxes as may be due to the Government or any of its agencies;

c. Collect, recover and pay to the designated account any tax under any provision if this Act or any other enactment or law; 
d. Review the tax regimes and promote the application of tax revenues to stimulate economic activities;

e. Carry out examinations and investigations, in collaboration with relevant law enforcement agencies, with a view to enforcing compliance with the provisions of the Act;

f. Make, from time-to-time, a determination of the extent or financial losses by government arising from tax evasion or tax waivers;

g. Adopt measures to identify, trace, freeze, confiscate, or seize proceeds from tax fraud or evasion;

h. Establish and maintain a system for monitoring suspicious transactions;

i. Provide and maintain adequate data and information on all taxable persons, individuals, corporate bodies and all agencies of government involved in the collection of revenue for the purpose of efficient, effective and correct tax administration and to prevent tax evasion or fraud;

j. Issue taxpayer identification number to every taxable person in Nigeria;

k. Carry out and sustain rigorous public awareness and enlightenment campaign on the benefits of tax compliance; and

1. Carry out oversight functions over all taxes and levies accruable to the Government, and where necessary, query, subpoena, sanction and reward any activities pertaining to the assessment, collection of, and accounting for revenues accruable to the Federation.

Section 8 confers very wide powers on FIRS. It can collect and recover taxes due to any government department or agency (presumably including NCS) under the provisions of the FIRS Act or any other enactment or law. This would mean that FIRS has the power to collect the revenue due even to the NCS as set out by CEMA, 2004.

FIRS has the powers to enter any premises for the purposes of fulfilling its mandate and can seize and confiscate documents and assets. Unlike Customs Officers who directly have the powers of the Police, FIRS has to rely on law enforcement agencies to enforce its powers. However, the language of Section 36 of the FIRS Act is interesting. Section 36(1) says: "The Service may co-opt the assistance and cooperation of any of the law enforcement agencies in the discharge of its duties under this Act". Section 
36(2) says: "The law enforcement officers shall aid and assist FIRS officers in the execution of any warrant of distraint and the levying of distraint". The use of the word 'co-opt' suggests that FIRS can include a law enforcement officer as part of its team when visiting any address, and the word 'shall' in statutes is usually interpreted by the law to mean 'must'.

The FIRS Act 2007 gives the Service a specific responsibility to carry out and sustain a public enlightenment and awareness campaign on the benefits of taxation. This responsibility is not in CEMA which governs the NCS.

Lastly, and unusually for the Nigerian public service, FIRS has a specific responsibility to reward any activities pertaining to revenue administration, in addition to the usual powers to punish and sanction. This point is important when discussing the issues of pay and motivation later in this chapter.

\subsubsection{Mode of Operation}

According to the FIRS Corporate Plan of 2010, the Services Vision Statement is "To deliver quality services to taxpayers in partnership with other stakeholders and make taxation the pivot of national development". Its Mission Statement is "To operate a transparent and efficient tax system that optimises tax revenue collection and voluntary compliance". It sets out the core values of the organisation to be Professionalism, Integrity, Efficiency, and Ownership and Collective Responsibility. It is not usual in the Nigerian public service for a government ministry, department or agency to develop annual corporate plans. FIRS has had annual corporate plans since 2008, each containing the vision statement, the mission statement, a restatement of the FIRS mandate, a restatement of the core values, medium and longterm visions for the tax system, strategic objectives for each year, a SWOT analysis, goals for the year in view, and role statements, key responsibilities and key performance indicators for each department, including the Office of the Chairman. These annual corporate plans fall out of the FIRS Medium Term Plan for 2008 to 2011. It is worth noting that the Chairman of FIRS was one of the leading tax consultants in the country before her appointment and had worked in the most prestigious accounting and consultancy firms 
in Nigeria, including Arthur Andersen. After working at Arthur Andersen for a decade, she set up her own consultancy firm, which she ran for 8 years before being appointed Chairman of FIRS.

The Executive Chairman of FIRS doubles as the Chairman of the FIRS Board and the Chief Executive Officer of FIRS. Forming part of the Office of the Chairman are two important departments: Corporate Communications and Internal Affairs. The main role of the Corporate Communications Department is to fulfil FIRS's statutory responsibility for public enlightenment and taxpayer education. The Internal Affairs Department is responsible for quality assurance, value-for-money, internal audit, and system audit which reviews internal and external systems to minimise the risk of fraud.

Beneath the Office of the Chairman, FIRS has four main departments, each headed by a Coordinating Director. The Office of the Chairman also has a Special Adviser to the Chairman who has the status of a Coordinating Director. The departments, known as 'Groups' are:

- Compliance and Enforcement Group, whose main role is to encourage voluntary compliance by taxpayers with minimum use of enforcement;

- Corporate Development Group, whose main role is to coordinate the implementation of the corporate plans of the Service, modernising working practices and ensuring that officers possess the technical skills to do their jobs;

- Support Service Group, whose main role is to provide support services to other departments for the attainment of the organisational goal of maximising revenue collection; and

- Tax Operations Group, whose main role is to manage the taxpayer population and their compliance with revenue laws.

Each Group has a huge organisational infrastructure beneath it. For instance, the Corporate Development Group has a Director of Modernisation who oversees programme management and control, change management and communication, and donor management and procurement. The Support Services Group has Directors for Tax Revenue 
and Accounting, Finance and Accounting, Facility Management, Human Capital Management and Security and Safety.

Just delving a bit further down, for purposes of illustration, the Director Human Capital Management in the Support Services Group is the responsible for:

- Planning and Organisation - Organisational Development and Job Evaluation, Manpower Planning, Human Resource Strategy and Management Information System, and Human Resource Policies and the capacity building of Human Resource staff;

- Human Capital Administration - Recruitment and Selection, Compensation and Benefits, Human Capital Records Management, and Exit Management;

- Employee Relations - Reward, Recognition and Welfare, Investigation and Discipline, and Appeals and Industrial Relations; and

- Individual Performance Management - Performance Evaluations, Career Development and Succession Planning, Promotion, and Coaching, Counselling and Mentoring.

In my view, FIRS has the most elaborate professional structure of any organisation that I have seen in Nigeria. The scope of issues covered by the Human Capital Management Department are things are more often found in the Human Resource departments of organisations in developed countries than in the developing world. Issues such as job evaluation, HR planning, exit management, reward and recognition, succession planning and coaching, counselling and mentoring, are not issues that many public sector organisations in developing countries tend to focus on.

Part IV of the FIRS Act sets out a number of offences and penalties. For most offences, the maxim sentence is a fine of about $\$ 1,300$ or imprisonment for a term not exceeding 3 years or both fine and imprisonment. The offences covered include obstruction, false declaration, counterfeiting of documents, fraud by FIRS officers and impersonation. The two most serious offences are where in the commission of any of the offences above a person is armed with an offensive weapon, in which case the penalty is 5 years imprisonment (no option of fine); and where a person, while armed with an 
offensive weapon, causes injury to any authorised officer of the service engaged in their lawful duty, for which the maximum punishment is 10 years imprisonment with no option of a fine.

FIRS currently has a staff strength of 6,244 officers, of which nearly 2,000 were recruited over the last two years. Staff recruitment is done openly and transparently, although there was a newspaper allegation that about a quarter of the jobs had been "hijacked" by Senators and Ministers. The allegation was stoutly denied by FIRS (Economic Confidential, 2010).

\subsection{Application of Dependent Variable}

Performance is the dependent variable in this research. Although the performance of public sector organisations could be viewed through the lenses of inputs, outputs, outcomes and impact, I will focus my assessment of performance on the extent to which a public sector organisation has achieved its pre-determined goals with regards to its outputs, given a certain level of inputs. This is because it is often reasonable to hold public sector organisations to account for outputs, rather than outcomes and impact which can be influenced by many intervening factors (OECD, 2009, p.63).

Of the case studies in this research (anti-corruption, regulatory quality and revenue administration), measuring the performance of the revenue administration agencies should perhaps be the most straightforward, given the primary function that they perform: collection of revenue. The main statutory function of the NCS is to collect and account for revenue, and that of FIRS to assess, collect, account for and enforce the payment of taxes. In Chapter 3, I had set out the performance criteria that I will use here to be Total Estimated Collection Potential (as determined by government targets) compared with Actual Collection.

In adopting the measurement criteria above, I am not oblivious of the argument of some authors on the subject that "the 'best' tax administration is not simply that which collects the most revenues" (Soest, 2010, p.61); or 
that the output should be distinguished from process, i.e. how the tax is collected. The 'how' element brings in the extent to which taxpayers are voluntarily complying, rather than being forced to pay. NCS, of course has other functions, such as preventing smuggling and the dumping of substandard goods in the country. Similarly, beyond collecting revenue, FIRS has many other specific mandates, such as enforcing compliance and educating taxpayers on the need to pay taxes. I am not assessing the performance of these organisations by looking at these other factors, because as Christian von Soest points out:

[...] as the collection of taxes is the ultimate goal of every tax administration, a revenue-collecting institution can only be termed to have a high capability to raise revenue if it generates a high output (Soest, 2009, p.62).

This view is supported by practitioners such as Osy Chuke, Coordinating Director, Corporate Development Group, FIRS, who says "The most singular index of performance is how much money we collect" (Tell, 2011, p. 17).

Soest, rightly in my view, follows the results oriented approach developed by Boesen and Therkildsen (2005) which argues for a focus on specific organisational results or outputs. However, Boesen and Therkildsen go on to say that outputs should contribute to development outcomes and impact and should therefore be "appropriate"; and that appropriate outputs, even when well intended, do not automatically translate into development outcomes and impact (Boesen and Therkildsen, 2005, p.3.) Beyond agreeing with their approach on focusing on results or outputs, for the purposes of this research, I will not yet engage in the debate as to whether or not outputs should contribute to development outcomes or what "appropriate" outputs should be. Suffice it to say, at this stage, that the government has set out in very clear terms what it expects each organisation to achieve in the enabling laws of the organisation. It goes further to set annual targets that they are expected to meet and they are given a set of inputs (budgetary provision for staff and equipment) with which to deliver the desired output. We will return to the issue about whether the simplistic output measures adopted in this study are sufficient to classify an organisation that meets its targets as an atypical organisation. 
In assessing atypical performance in this research, the period of 8 years is that which is used to determine whether atypical performance has been achieved and sustained. The performance of NCS for 2004 to 2011 is shown below in billions of Nigerian Naira $(\mathrm{Nb})$ :

\section{$\underline{\mathrm{NCS}}$}

\begin{tabular}{|l|l|l|l|l|}
\hline Year & Target $\mathbf{( N b )}$ & Actual $\mathbf{( N b )}$ & Difference $\mathbf{( N b )}$ & Variance \\
\hline 2004 & 249 & 258 & 9 & $4 \%$ \\
\hline 2005 & 271 & 279 & 8 & $3 \%$ \\
\hline 2006 & 227 & 244 & 17 & $7 \%$ \\
\hline 2007 & 280 & 323 & 43 & $15 \%$ \\
\hline 2008 & 347 & 344 & -3 & $-1 \%$ \\
\hline 2009 & 650 & 514 & -136 & $-21 \%$ \\
\hline 2010 & 561 & 547 & -14 & $-3 \%$ \\
\hline 2011 & 596 & 742 & 146 & $24 \%$ \\
\hline Total & 3181 & $\mathbf{3 2 5 1}$ & $\mathbf{7 0}$ & $\mathbf{2} \%$ \\
\hline
\end{tabular}

Table 11: Actual Performance of NCS 2004-2011 ${ }^{36}$

Although NCS had exceeded its targets for 5 out of the 8 years in view, overall it has just about met its targets over the 8 years. Cumulatively, its actual collection was $2 \%$ higher than its estimated collection potential as expressed in government targets. NCS has argued that the targets set for it are too high, that it is not consulted when the targets are set and that import restrictions affect NCS's ability to collect revenue. ${ }^{37} \mathrm{I}$ believe that there may be some merit in the argument about the effect of import restrictions on revenue performance. As stated earlier in this chapter, Nigeria has a very long import prohibition list which the World Bank believes promotes corruption. Because there is such a long list of prohibited items, importers

\footnotetext{
${ }^{36}$ Figures prepared for me by Mr Taju Olanrewaju and Mr Ohis Ohiwerei of the NCS.

${ }^{37}$ My interview with M.L. Adegoke, Deputy Comptroller General of Customs, Tariffs and Trade, on 1 August, 2011.
} 
are tempted to bribe customs officers to be able to bring in the goods. There are also cases in which the customs officer may privately believe that the ban on a particular item does not make sense and will therefore "collect the duties for my family, since the government doesn't want it. The importation of shoes and bags is banned but how many shoes and bags used by Mr. President's wife are made in Nigeria? (Unnamed Customs Officer, 2011)."

However, given that NCS is rated as the $3^{\text {rd }}$ most corrupt agency in Nigeria (NOI Polls, 2008), it is possible that more duties are "collected for families" of customs officers than only in cases where officers feel that a ban in unjustified. $35 \%$ of businesses surveyed reported having had to pay bribes to customs officers to clear goods that they had legitimately imported (NBS/ EFCC, 2007, p.4). When bribes are paid, part of the 'services rendered' will often be to reduce the assessment of duties payable (Unnamed Customs Officer, 2011).

Mr Ken Ukoha, President of the National Association of Nigerian Traders is very clear that NCS very probably under-reports the revenue that it collects. While he doesn't present any documentary evidence, in my interview with him on 23 March, 2011, he gave me a very compelling account of various instances of corruption involving customs officers at the ports. This included a personal experience that he has where a customs officer is alleged to have demanded a bribe of $\mathrm{N} 40,000$ (about \$267) from him before he could clear a vehicle that had been imported legitimately and genuinely. His only 'offence' was that the exporter from Germany had spelt a street name as 'Baba tunde', rather than 'Babatunde' (one word). Refusal to oblige the customs officer would have meant that the vehicle would incur demurrage at the ports and could eventually be sold off. He only avoided paying the money by getting a senior NCS officer to intervene. Such 'revenue' he argues does not go to government but to the pockets of NCS officers. He believed that if all the monies that all NCS officers collected were paid to government, the organisation would meet its targets 10 times over, every year.

Ukoha, informed me that Nigeria is the only country in the world that he is aware of where the government sets revenue targets for its customs service. He feels that the setting of targets for NCS was as a result of government's suspicion of grand corruption in NCS. Setting annual targets for them was 
the only way in which government could at least get a share of the money they collect. He argued very strongly that I could not look at NCS's performance from a revenue perspective alone. He agrees that NCS is now contributing some revenue to government, but feels that the corruption in the service damages the economy much more than the revenue that they generate benefits it. He claims that the NCS mounts 57 checkpoints over a 100 kilometre distance, rising to 100 at night, for a length of road that should only have 3 checkpoints. Each checkpoint is an illegal toll gate for corrupt NCS officials.

To check the validity of Ukoha's claims, I was able to access official figures from the Abidjan-Lagos Corridor Organisation, an initiative supported by Economic Community of West African States (ECOWAS) and the World Bank. The official figures (ALCO, 2011) show that Nigeria has, by far, the highest number of checkpoints in the sub-region. As at June 2011, Nigeria had 34 checkpoints, compared to the 3 that it should have (Togo has only 3 ), and has 32 checkpoints for every 100 kilometres of road, as compared to 3 that it should have. This means that there is an NCS checkpoint for every 3 kilometres of road. It was not possible to verify what the actual night-time numbers were, but the official figures lent persuasion to Ukoha's claims.

\section{$\underline{\text { FIRS }}$}

The performance of FIRS for the same period of 8 years in billions of Nigerian Naira is shown below:

\begin{tabular}{|l|l|l|l|l|}
\hline Year & Target $\mathbf{( N b )}$ & Actual $\mathbf{( N b )}$ & Difference $\mathbf{( N b )}$ & Variance \\
\hline 2004 & 1180.00 & 1194.8 & 14.8 & $1 \%$ \\
\hline 2005 & 1304.40 & 1741.80 & 437.4 & $34 \%$ \\
\hline 2006 & 3054.10 & 1866.20 & -1187.9 & $(-39 \%)$ \\
\hline 2007 & 1753.32 & 1841.11 & 87.79 & $5 \%$ \\
\hline 2008 & 2274.40 & 2972.20 & 697.8 & $31 \%$ \\
\hline 2009 & 1909.00 & 2196.50 & 287.5 & $15 \%$ \\
\hline 2010 & 2557.30 & 2839.33 & 282.03 & $11 \%$ \\
\hline 2011 & 3639.07 & 4628.47 & 989.4 & $27 \%$ \\
\hline Total & $\mathbf{1 7 6 7 1 . 5 9}$ & $\mathbf{1 9 2 8 0 . 4 1}$ & $\mathbf{1 6 0 8 . 8 2}$ & $\mathbf{9 \%}$ \\
\hline
\end{tabular}

Table 12: Actual Performance of FIRS 2004-2011 ${ }^{38}$

\footnotetext{
${ }^{38}$ Prepared for me by Dr. Asheikh Maidugu and Mr Obi Okeke of FIRS.
} 
FIRS has consistently exceeded its targets every year since 2004, except for 2006 when the target set by the Federal Government grew by $134 \%$ on the previous year's target. That target was adjusted downwards in 2007 and the progressive increase in actual collections is apparent. Overall, FIRS has exceeded its targets over the 8 years by $9 \%$. One could be tempted to argue that rising costs of crude oil would have positively influenced FIRS's performance since Petroleum Profits Tax represents a sizeable chunk of the money that FIRS collects. However, FIRS has also exceeded the targets for non-oil revenue collection every year from 2004, save for 2011 where its collection came marginally under target. FIRS does not handle any cash. All personal and corporation taxes which FIRS collects are paid directly into the Central Bank of Nigeria. This means that, unlike NCS, there have been no allegations that FIRS collects more revenue than it remits.

\subsection{Application of Explanatory Variables}

The explanatory variables related to my research question are set out as various internal and external factors. I will now examine these internal and external factors in the context of NCS and FIRS to see how they affect the dependent variable (performance).

\subsubsection{Internal Factors}

Internal factors are those managerial factors that affect how the organisation is run, such as leadership and staff motivation, as opposed to factors external to the organisation, such as policy and political considerations that the organisation has little control over.

\section{Leadership}

The NCS website alludes to the organisation's paramilitary status in several places. There are military-style formations and parades, and a clear command and control structure. The Comptroller General of Customs moves about in a large convoy of cars, full of armed officers and proceeded 
by motorcycle outriders. NCS officers were uniforms with their ranks displayed on their shoulders, much like policemen.

The current Comptroller General of Customs (CGC), Dikko Inde Abdullahi, was appointed in 2009. His predecessor, Hamman Bello, is facing trial for corruption (Nation, 2009). Upon coming to office, Abdullahi unveiled a 6Point Agenda for the transformation of the service. These are:

1. Maximising the potentials of the service through capacity building;

2. Moral rebirth for discipline and integrity in the service;

3. Incentivising productivity and ensuring an enhanced welfare package for officers and men of the service;

4. Improving the use of technology;

5. Collaborating with stakeholders and international organisations; and

6. Improved public relations.

Progression through the cadres in NCS is by promotion. Therefore, no other qualification is required to be the CGC, other than being a customs officer who has risen to the rank of Assistant Comptroller General of Customs. It is not usual to appoint an outsider (someone who is not a customs officer) to the CGC position, given the paramilitary nature of the NCS. It has happened twice before under military rule, but it is seen as an aberration. ${ }^{39}$

Usually, the President appoints the CGC from the body of Assistant and Deputy Comptrollers General. Seniority plays a part, as does Federal Character, but the President has the ultimate authority to choose who he likes for the position. If the President wanted to appoint someone of lower rank than Deputy CGC, he would have to retire every officer that is senior to that person first. ${ }^{40}$ This is what the President did when he chose to appoint an Assistant Inspector General of Police, rather than a Deputy Inspector General of Police as the new Inspector General of Police (National

\footnotetext{
${ }^{39}$ My interview with Mathias Abutu, Comptroller of Customs, NCS, on 12 March, 2012.

${ }^{40}$ My interview with Taju Olanrewaju, Deputy Comptroller of Customs, Strategic Research and Policy, NCS, on 12 March, 2012.
} 
Mirror, 2012). Not doing so could lead to a breakdown of discipline and the command structure.

Abdullahi has focused his efforts on improving staff welfare, training, the use of technology, tight performance management, incentivising performance and gaining public support for the reforms in NCS. Being that the CGC statutorily sits on the board of FIRS, he would have been directly exposed to the strategies and tactics employed to reform that organisation.

Section 3 (2)(a) of the FIRS Establishment Act 2007 says that the Executive Chairman "shall be experienced in taxation". There is therefore an inherent requirement for technical expertise. The previous Chairman of FIRS was the Managing Director of a bank and a Chartered Accountant, and the current Executive Chairman holds a First Class Degree in Accounting, is a Chartered Accountant, and was one of the country's foremost tax consultants prior to her appointment.

The appointment of Ifueko Omoigui-Okauru as Executive Director of FIRS followed a similar patter to that of others appointed by President Obasanjo. She describes her appointment process thus:

In May 2004, I got a call asking if I would be interested in being chairman at FIRS. I met with then President Olusegun Obasanjo. I was told to respond in two days. I think I met him on a Thursday and I was told to respond on or before Saturday and by Monday, I assumed duty (Tell, 2011, p.9).

In my interviews with Ifueko Omoigui-Okauru on 7 January 2011 and President Olusegun Obasanjo on 28 October 2012, it was clear that she was specifically searched out for the job. She described how she had first met the President's Principal Secretary, before meeting the President:

What he now told me was that they have just finished a study group report project and that they were looking for somebody to drive the implementation of the reform, and that my name came up. He felt that it was an interesting opportunity to shape efforts and change the situation, and that this was a very good opportunity because I had the 
opportunity to draft whatever law I felt was important for the tax system.

The FIRS that Omoigui-Okauru met upon her appointment was one in which staff morale was extremely low. FIRS officers had a reputation for being corrupt (a reputation that they are still struggling to shed), offices were dilapidated to the extent that staff could not come to work when it rained as roofs were caving in, files were scattered on the floor, members of staff had been promoted to be tax controllers without having ever being trained on tax, and computerisation was virtually non-existent. However, FIRS officers were fed up with their lot and were hungry for change. The situation that she met upon appointment would be the same that one would meet in many Nigerian public sector organisations. It is virtually identical to the situation that Dora Akunyili described meeting in NAFDAC when she was appointed, as set out in Chapter 5 of this study.

The strategy that Omoigui-Okauru adopted to carry out the reforms with had 7 core components that rested on a tripod of aggressive anti-corruption, taxpayer database management, and a reward system that is based on performance. Omoigui-Okauru describes the 7 core components as being similar to a bicycle spiral wheel which had Autonomy and Funding at its core. These core components serve as a fulcrum for 6 other strategic components:

- Build internal capacity focusing on structure, staffing and specialisation;

- Reengineer human resources, financial management and procurement;

- Audit the oil and gas sector;

- Strengthen investigation and enforcement;

- Provide taxpayer education; and

- Automate collections and the tax administration system.

It is easy to see that despite nuances in language and phrasing, the 6-Point Agenda of 2009 of the Comptroller General of Customs is virtually identical to what is called the '7+3 Strategic Flanks' of FIRS reform of 2004. 
Omoigui-Okauru has received several honours for her leadership. In 2000, 4 years before she came to the FIRS post, she received national honours for leading the technical team that fashioned out a 10-year vision for Nigeria. Although she was given another national honour in 2006 for championing tax reforms in Nigeria (after having been in FIRS for two years), the first honour is perhaps more significant as it could not be said to simply part of the perquisites of holding public office. In 2007, she was named 'Government Personality of the Year' by a prominent newspaper and, in 2008, students of Nigeria's oldest university gave her the same award. In 2009, FIRS, under her leadership, was named Government Agency of the Year by This Day newspaper. Perhaps most significantly, the Secretary General of the United Nations has named her as one of the global tax experts that would advise him on taxation and shape the United Nation's global tax practice (Tell, 2011, p.9).

Ifueko Omoigui-Okauru is charismatic in a very different way from Akunyili of NAFDAC or Ribadu of EFCC. She appears to prefer for her work to speak for her and to show the responsibility and personal example which Chinua Achebe describes as "the hallmarks of true leadership" (Achebe, 1983, p1). Although her approach has been described as "a silent revolution" (Tell, 2011), she has taken on a number of high-profile battles with the status quo. In 2007, she tried to get all aspirants for public office in that year's elections to prove that they had paid their taxes, as a precondition for seeking public office. The Independent National Electoral Commission refused and she informed me in the interview with her that she sued the government that appointed her. She has also authorised the sealing-up of many government offices for different tax offences and had the courage to order the arrest of the head of the Federal Capital Development Authority, the body that manages Abuja, the capital city of Nigeria (This Day, 2011g).

Dikko Indeh Abdullahi, Comptroller General of Customs, is similarly an unusual customs officer. He has received national honours from the Federal Government of Nigeria every year since he was appointed Comptroller General of Customs. The President has described him as the best thing to have happened to the NCS in its 120-year history and Abdullahi has also received praise from the World Customs Organisation (Sun, 2011). Appointed Comptroller General at the age of 48, he is relatively young, 
compared to the practice in the civil service where the Head of the Civil Service of the Federation is usually in his late 50's when appointed. Given the mandatory retirement age of 60 years, Nigeria has had 6 Heads of Service in 7 years, each spending about a year in post. Abdullahi therefore has time on his hands to embed the reforms he is introducing. Using the criteria of mandatory retirement at the age of 60 years or after 35 years of service, whichever is sooner, he has another 10 years to go.

\section{Management}

Management in this context is used to cover the totality of attributes and functions necessary to effectively run an organisation. In the context of this research, I will consider funding, recruitment processes, performance management and pay and conditions of service.

\section{Funding}

NCS is allowed to retain $7 \%$ of all the monies it collects. This is what the Service is funded from, although it believes that this proportion is insufficient to fully fund its activities. It has therefore submitted a proposal to the Federal Executive Council to retain an additional $4 \%$ of the revenue from import and export duties (Abutu, 2012). The NCS has also received support from donors, although this has not been quantified in monetary terms.

Section 15 of the FIRS Establishment Act says that the National Assembly shall determine the percentage that FIRS can keep out of all non-oil and gas revenue collected by the service. The percentage currently set by the National Assembly is 4\%. As FIRS collects about 6 times what NCS collects, the $4 \%$ for FIRS represents a far greater amount than the $7 \%$ that NCS is allowed to utilise. There is no doubt that FIRS has had more resources with which to improve working conditions, staff remuneration, staff training and its image and publicity. However, there can be no automatic assumption that this, on its own, was responsible for differential performance. 


\section{$\underline{\text { Recruitment Process }}$}

Both NCS and FIRS recruit new entrants through open advertisement in national newspapers. Candidates are selected through a transparent selection process and the constitutional provisions of 'Federal Character' are applied to make sure that different parts of the country are adequately represented. Once recruited, officers of both organisations are put through rigorous training programmes before they can assume duty.

Although, from CEMA, the primary function of NCS is revenue generation and management, Customs officers are trained in a wider range of duties, including the prevention of smuggling. Officers are also periodically moved around from department to department and from location to location. However, officers in the Department of Tariff and Trade, the main revenue management department of NCS, are given specialised training in collecting and accounting for revenue.

Because tax administration is a technical, professional endeavour, the training in FIRS is more accounting-oriented in nature. Depending on the department for which an individual is recruited, they could be given indepth technical training on audit, enforcement and compliance, calculating tax liability, or developing tax policy.

\section{Performance Management}

Both NCS and FIRS take the issue of performance management seriously. Departments, units and individuals that exhibit exemplary performance are recognised and given bonuses. Similarly, erring officials are sanctioned. Both FIRS and NCS have a policy of zero tolerance for corruption and officers that are adjudged to be corrupt, following a disciplinary process, are dismissed. NCS has handed down various forms of disciplinary sanctions to 74 officers in the last two years, ranging from demotions in rank to outright dismissal (Leadership, 2011).

FIRS has an elaborate performance management system. Each Group within FIRS (including the Chairman's Office) has an annual statement of roles, key responsibilities and key performance indicators. Each statement is signed by the responsible Coordinating Director and countersigned by the Executive 
Chairman. This process is cascaded down through all tiers of staff (FIRS 2010 Corporate Plan).

M.L. Adegoke, Deputy Comptroller General of Customs in charge of Tariffs and Trade, described the NCS performance management system to me in my interview with her on 1 August, 2011:

Staff performance is managed both in terms of revenue and discipline. In terms of revenue, there is always a management meeting to ensure that the targets are passed on to all Area Commands, for instance the ports and borders. The targets are broken down and monitored. There are regular meetings where officers are called in to report on their revenue performance. We also monitor what is coming in through the banks. Area Commands also make returns, so headquarters can see how each command is doing. We also use shipping manifests detailing the goods being imported into the country to cross-check returns that are submitted to headquarters [...] If you have good customs officers, you must take care of their integrity. You must look after their welfare to deter them from corruption [...] You can be given promotion if you perform well. You can get an award annually. ${ }^{41}$

The point that Adegoke made about staff performance being additionally assessed from the perspective of discipline is pertinent, particularly as NCS prides itself in being a paramilitary organisation. Therefore, refusal to obey a legitimate order issued by a superior officer would probably attract greater and swifter sanctions in NCS than it would in FIRS.

\footnotetext{
${ }^{41}$ My interview with M.L. Adegoke, NCS, on 1 August, 2011.
} 


\section{$\underline{\text { Pay and Conditions of Service }}$}

The pay of NCS officers, like other paramilitary organisations such as Immigration, Fire Service, and the Prisons Service was covered by the Consolidated Para-Military Salary Structure (COMPASS) issued by the National Salaries, Incomes and Wages Commission. Circular SWC/S/04/S.306/1 of 18 January 2007, sets out the remuneration for officers up to the rank of Assistant Comptroller. Chike Ogbechie of the Salaries and Wages Commission explained in my interview with him on 23 June 2011 that the rank of Assistant Comptroller General was placed on the same threshold as that of a Director in FIRS for pay purposes, while the rank of Deputy Comptroller General of Customs is viewed as being at par with that of Coordinating Director in FIRS.

Within three months of coming to office, the current Comptroller General of Customs was able to effect a 100\% increase in the salary of NCS officers. Therefore, when COMPASS was reviewed by Circular SWC/S/04/VIII/307 of 1 July, 2010, the NCS was no longer shown as part of that structure. Although it was not possible to get the exact figures in the NCS pay scheme, Chike Ogbechie of the Salaries and Wages Commission explained that the new salary would have had to be benchmarked against that of similar organisations (most probably FIRS) before it could be approved by the Commission. It is therefore likely that both organisations earn about the same, although FIRS has more resources and less people and can probably afford to pay its staff more. The Salaries and Wages Commission is statutory empowered to approve all public sector pay and would normally do all in its powers to avoid wide variations between similar organisations. The Approved Consolidated Salary Structure for FIRS effective from 1 July 2011 shows the lowest pay rate as N543,254 and the highest pay, below the position of Coordinating Director, as N9,713,800. Coordinating Directors, equivalent to the rank of Deputy Comptroller General of Customs, earn N12,210,942 (\$81, 406 per annum at the exchange rate of N150 to $\$ 1$ ). Unfortunately, it was not possible to obtain the exact figures for NCS.

Mathias Abutu, Controller of Customs at NCS, explained that the effect of the $100 \%$ increase in salary was an immediate upsurge in morale and support for the new Comptroller General. In addition to the salary increase, he ensured prompt payment of salaries through electronic transfer to 
officers' accounts before the $28^{\text {th }}$ day of every month, and took steps to ensure that every NCS officer was accommodated either in barracks or private accommodation. This earned the Comptroller General the nickname of "Mr Welfare." 42

\section{Technical Capacity}

Both FIRS and NCS have focused heavily on building the technical capacity of their workforce. In the 2 years that Abdullahi has been in post, more than $60 \%$ of the NCS workforce of 16,000 has undergone training locally and internationally (Abdullahi, undated). The situation is similar in FIRS where Achillies Amawhe said: "In the last 3 years, we have done more training than we did in the 20 years before 2004 when the Chairman was appointed." 43

Both organisations have also invested heavily in information and communication systems, and have automated a number of their functions. FIRS has a 'Pay Direct' system which has automated the process of collection. It has also developed a Tax Identification Number system to ensure that taxpayers are identifiable and traceable. This has greatly reduced tax avoidance and the provision of conflicting information to different parts of government. For instance, before the Tax Identification Number system, a company could under-declare its income to FIRS for assessment purposes, but submit a much higher income statement to other government agencies when bidding for government contracts. This is similar to the Automated System for Customs Data (ASYCUDA) system used by the NCS. The 'Direct Trader Input' system of NCS is also very similar to the FIRS 'Pay Direct System'.

There is currently an ongoing FIRS/ NCS data integration project. When completed, both organisations will share data about importers, exporters and other taxpayers (Vanguard, 2011a).

\footnotetext{
${ }^{42}$ My interview with Mathias Abutu, NCS, on 12 March, 2012.

${ }^{43}$ My interview with Achillies Amawhe, FIRS, on 22 December, 2011.
} 
Compared to the rest of the Nigerian public service, there is also a reasonably high level of computer awareness in both organisations. There is internet connectivity in the headquarters of both organisations and the officials that I interviewed could at least access documents on their computers and print them off, unlike in many other public sector organisations in Nigeria. Performance data is also recorded electronically and can easily be retrieved.

\section{Public Support}

Getting citizens to pay tax in a resource-rich country is a difficult endeavour. The task is made even more difficult where citizens feel that the resources available to government are not deployed to the benefit of the ordinary citizen. Emmanuel Obeta, Director of Corporate Communications at FIRS describes the problem quite well:

People ask: 'why should I pay tax? What has the government been doing with the money it collects?' Your inability to explain what the government does with the money already puts you at a disadvantage. ${ }^{44}$

Being 'tax collectors', FIRS and NCS do not necessarily enjoy public support in the way that EFCC or NADFAC does. This is significant when we discuss the issue of Demand later on and the extent to which pressure from citizens catalyse performance. There is often no pressure from citizens for tax collecting agencies to become better at what they do, yet these organisations are delivering on their mandates.

From the NOI Polls of 2009, 50\% or respondents rated the NCS as effective, compared to $30 \%$ for FIRS. Obeta recognises the problem of the poor perception of FIRS and confirms that FIRS is taking steps to address it. This includes sponsoring a television programme called 'Tax Matters', educating journalists about FIRS's work, and publicising its own improving performance. Obeta is keen to stress that in educating journalists, FIRS does not hand out brown envelopes of cash to journalists to encourage

\footnotetext{
${ }^{44}$ My interview with Emmanuel Obeta, FIRS, on 23 December, 2011.
} 
favourable reportage. The need to portray itself as an ethical and professional organisations means that FIRS does not engage in the brownenvelope practice which is common in the Nigerian public service. There have also been a number of high-level arrests and prosecutions of tax avoiders, so the service is building credibility in the eyes of the public. Given the plethora of awards given to FIRS and its Chairman by the press, the efforts of FIRS to obtain public support for its activities seem to be beginning to bear fruit.

The NCS has the dual function of generating revenue and protecting the society from the importation of injurious goods. Abutu believes that this is responsible for the twin image that NCS has. On the one hand, members of the public are supportive of the work of the NCS, as borne out in the NOI Polls survey of 2009. However, he points out that most members of the public have little or no contact with customs officers. The perception of entrepreneurs and importers are different from that of the general public. Businesses claim to frequently pay a bribe to customs officers to clear their goods at the ports (EFCC/ NBS, 2009). G.O. Adeyemo, Assistant Comptroller General of Customs, Strategic Research and Policy Department, worked at the ports of 7 years. In my interview with her on 12 March, 2012, she wondered why there would be a need to pay anyone any bribes if what is imported is legal and the importer pays the correct duties. She believes that the key to reducing corruption and allegations of corruption is to minimise the contact between importers and customs officers. An inspection should simply be carried out, an assessment done impersonally and transmitted electronically, and an importer pays to the bank and clears his goods. "The less the contact, the less the corruption." ${ }^{45}$ While this argument is tenable at the ports, it is difficult to avoid contact with customs officers when they have mounted several checkpoints on the roads, in some cases less than a kilometre apart from each other.

\footnotetext{
${ }^{45}$ My interview with G.O. Adeyemo, NCS, on 12 March, 2012.
} 


\subsubsection{External Factors}

External factors are those things that may affect organisational performance but are not within the control of the organisation. These are political and policy considerations, institutions and the expectations that policy makers have of organisations. I will now assess how these external factors relate to NCS and FIRS.

\section{Political and Policy Considerations}

Like many other mineral-rich countries, Nigeria has often talked about the need to diversify its economy away from oil. In 1999, when Nigeria returned to democratic rule after decades of military dictatorship, the GDP growth rate was only $2.8 \%$, making Nigeria's one of the slowest growing economies in the world on per capita basis (Olaopa, 2009, p.165). This was despite the fact that the country had been earning $\$ 11$ billion annually from oil and gas for the 20 years preceding the return to democratic rule. In 2003, the country paid $\$ 5$ billion to service internal and external debts (including $\$ 2$ billion representing arrears from 2002), a level of debt servicing that left very little money for development initiatives. Therefore, in 1999, President Obasanjo inherited an economy that was "stagnant and uncompetitive" (Olaopa, 2009, p.166).

Several initiatives to reposition the country were undertaken in the first term of the Obasanjo administration (1999-2003). One of the most significant initiatives was what became known as the 'Kuru Declaration', a resolve by government, in 2001, to build a democratic and economically prosperous country (Olaopa, 2010, p.206). When President Obasanjo was re-elected for a second term in 2003, he built an Economic Team made up world-renowned Nigerian experts to drive the regeneration of the economy. The erstwhile desire to diversify away from oil became an imperative for the Economic Team and it sought ways to boost non-oil revenue by focusing on agriculture, tackling corruption and waste, and raising tax revenue. Although Ifueko Omoigui-Okauru traces this focus on non-oil growth to advice that Warren Buffet, the investment banker, gave to Obasanjo in $2002 / 3,46$ it is likely that many other people shared the same views. For

\footnotetext{
${ }^{46}$ My interview with Ifueko Omoigui-Okauru, Chairman of FIRS, on 7 January, 2011.
} 
instance, Obasanjo himself had been a farmer and had focused heavily on agriculture when he was military head of state in the 1970s. The Economic Team that he assembled also included notable economists, academics and professionals (including Omoigui-Okauru herself), who had a clear view about the reforms that needed to take place for the economy to grow.

The 2003 Study Group on Nigerian Tax Reform laid the foundation for the reform of FIRS. The main thrust of its recommendations was the need to make a paradigm shift from near-total dependence on oil revenue to creating an efficient revenue administration system based on improved tax processes (Tell, 2011, p.6). Additionally, in 2004, CEMA changed the primary function of the NCS to revenue generation, for the first time in NCS's history. Non-oil growth became a major focus of the National Economic Empowerment and Development Strategy which the Federal Government launched in 2004 (Federal Government of Nigeria, 2004c). The economic reforms that were undertaken by President Obasanjo made it possible for Nigeria to obtain debt relief from the Paris Club of Creditors in 2005. This made available additional resources with which to focus on national and human development.

It is clear, therefore, that the political and policy environment was conducive for revenue administration improvements, both for FIRS and NCS, during the Obasanjo regime. Interviews that I have conducted at FIRS and NCS, and with senior government officials, confirms that the government continues to place a high premium on non-oil economic growth, and that the political and policy environment remains conducive for improved revenue administration.

A.L. Ikpebe, Comptroller of Customs, Enforcement, informed me in my interview with him on 22 March 2012, that the current President, Goodluck Jonathan, used to be a customs officer, and, therefore, understands the service. He says that "before we even finish explaining, he already understands what we need". This may provide some explanation for the support that NCS has recently been receiving from government. Ikpebe explains that, unlike before, salaries are now decent and are paid on time; there is now money for operations and officers no longer have to fund official duties from personal resources; officers now have decent accommodation, logistics have greatly improved; and there are sufficient 
operational materials including arms and ammunition and uniforms. All these have restored pride to officers of NCS. I asked why these things were not in place before the current Comptroller General and he explained that previous leaders did not have the clout to request and secure the required resources. It also helps that the current President was a former customs man.

\section{Institutional Factors}

NCS and FIRS share a similar history, having been creations of the colonial administration that ruled Nigeria before independence. Both organisations have existed in one form or another for more than a century. They go through the same processes to obtain government funding, operate the same public service rules and are both affected by the same political economy constraints, in that citizens of oil-rich countries, like Nigeria, question why they should pay any form of tax whatsoever. This is made worse by the difficulty of demonstrating the existence of a social contract with citizens for very many years. However, cumulatively, over the last 8 years, both NCS and FIRS have both been fulfilling their mandates, despite the difficulties of the operating environment. In terms of revenue performance, cumulatively, FIRS has exceeded government targets by $9 \%$, while NCS has exceeded its targets by $2 \%$.

Both organisations have enforcement powers, including powers of seizure, confiscation, search and arrest. However, while the NCS has the same powers as the police (including the power to bear arms), FIRS has to rely on law enforcement agencies, like the police, to give effect to its enforcement powers.

Both organisations have suffered from negative public perception but have made strenuous efforts to change the ways in which they carry out their functions. I believe that it is fair to say that, in the recent past, FIRS has had a longer history of reforms than NCS. The current Executive Chairman of FIRS would have been in post for 8 years by May 2012, while the current Comptroller General of Customs has only been in post since 2009. His immediate predecessor is under investigation by the EFCC for corruption, and there is no evidence that any serious efforts were made to reform the Service during his tenure. 
While FIRS has complete autonomy from the Federal Ministry of Finance, the NCS is still overseen by the Minister of Finance, who is the chairman of the NCS Board. The autonomy that FIRS has means that it does not have to refer matters upwards to any Minister and can act as it deems fit. NCS, on the other hand, is supervised by the Minister of Finance, although most operational decisions are taken by the Comptroller General of Customs.

\section{Clarity of Expectations}

Both the CEMA of 2004 and FIRS Establishment Act of 2007 set out in very clear terms what the government expects from NCS and FIRS - collect taxes and duties and enforce compliance. Government expectations are set out clearly in the Federal Government's annual budget, expressed as annual revenue targets for both organisations.

However, the debate about what the proper role of NCS should be is far from settled. This has a bearing on the clarity of expectations. All the officers interviewed in NCS saw the proper role of the NCS as security and the protection of society from the importation of illegal arms and ammunition, narcotics, fake and substandard pharmaceuticals (working with NAFDAC), and preventing Nigeria from being a dumping ground for substandard products manufactured abroad. Revenue generation was seen as incidental to this main function. This view is shared by development partners such as USAID and private sector partners including the Association of Nigerian Licensed Customs Agents in my meetings with them on 14 March, 2012. However, all NCS officers interviewed recognised the fact that government had placed emphasis on revenue for assessing NCS's performance and that, as public servants, they had no choice but to meet the revenue targets.

Another issue affecting the clarity of expectations for NCS is the tension between import prohibition and trade liberalisation, particularly within the ECOWAS region. While the Federal Ministry of Finance focuses on revenue from import duties, the Federal Ministry of Trade and Investment promotes trade liberalisation. NCS is in the ports and borders for both purposes. Olanrewaju argues that while revenue from custom duties and charges 
boosts the government's resources, trade liberalisation (as promoted by the World Trade Organisation and ECOWAS) actually has a greater potential to grow the economy. Trade liberalisation has the effect of exempting goods made within the sub-region from customs duties and charges, and will reduce the amount of money that NCS collects annually.

Consequently, there are four expectations on NCS which are not necessarily consistent:

1. Collect revenue

2. Protect the society

3. Promote local industry

4. Promote trade and investment

A.L. Ikpebe, Comptroller of Customs, Enforcement, provides a convincing argument that these roles are interdependent, rather than contradictory. This view was reinforced by Dera Nnadi, Chief Superintendent of Customs, in my interview with him on 23 March, 2012. However, I did not get the impression, from others I spoke with in NCS, that this view of interdependence is widely held by other NCS officers.

Government's expectations of FIRS are much clearer than they are of NCS.

\subsection{Demand}

Through the 3 case studies covered in this research, I have been exploring and building the concept of demand, i.e., a desire to do something, backed by the ability to make it happen, and a willingness to deploy that ability. I have argued that it is a convergence of these factors that make sustainable atypical performance possible. I have defined sustained performance as performance lasting over 8 years. I will now assess NCS and FIRS against the Demand Indicators set out in Chapter 2 to see to what extent the demand for improved performance could be said to have existed. 


\section{$\underline{\text { NCS }}$}

There was a political and policy imperative to raise revenue, as Nigeria was keen to raise its non-oil revenue. For the first time in the recent history of the NCS, the government made revenue generation the primary function of the Service and enacted CEMA in 2004 to enshrine this position in legislation. However, there is no evidence that the government headhunted for the kind of Comptroller General that it would need to achieve its targets at the time that it enacted CEMA, in the way that it did in FIRS. NCS has also not been given an unusual level of autonomy, given that it still reports to the Minister of Finance. However, during my fieldwork in NCS, it was never raised as a problem since the Minister is seen more as a figurehead than a chief executive. Most of the demand (and offers of support) by donors have been with regards to the non-revenue functions such as security and anti-smuggling, although there has also been support to automate revenue collection. Also, CEMA 2004 did not give the NCS any additional powers, only the clear responsibility to generate revenue.

However, by accident or design, NCS now appears to have a dynamic and reform-minded leader, who still has 10 years to serve before he is due to retire. For the first time in 4 years, NCS met its targets in 2011. A bill is currently in the National Assembly to repeal CEMA and create a consolidated law for NCS, and the Service appears to have learnt useful lessons from the reforms at FIRS. NCS has also been allowed to double the salary of its staff, and is currently arguing for a greater share of the revenue it generates. It is likely, therefore, that a convergence of all these factors, if and when they all come to fruition, will create a momentum for sustained improvement of NCS.

\section{$\underline{\text { FIRS }}$}

Like NCS, FIRS has similarly been under the same imperative to raise revenue. The government carried out a comprehensive review of the tax system, set out in clear terms what needed to be done and headhunted the type of leader that it wanted to carry out the reforms that it had identified. It gave FIRS complete autonomy from civil service bureaucracy in 2007, which meant that FIRS could recruit the quality of staff that it needed and pay them competitive wages. The FIRS Establishment Act 2007 also gives FIRS 
wide-ranging powers, which it has deployed to make even powerful government establishments comply with its law. There has also been no apparent adverse political interference since the reforms started. The reforms undertaken by FIRS are, in my view as a development practitioner, possibly one of the most thorough, wide-ranging and deep in the history of the Nigerian public service. Save for one year when the government inexplicable doubled the previous year's target, FIRS has exceeded its revenue targets every year for 8 years. Cumulatively, it has exceeded its targets by $9 \%$ in the 8 year period from 2004 .

FIRS is suggestive of a convergence of favourable institutional factors and highly effective organisational conditions. It is therefore likely that it will continue to perform atypically for the immediate future.

\subsection{Methodology}

In Chapter 3 of this dissertation, I had set out the methodological plan that will guide the entire study. In this section, I will now describe the extent to which this case study has been faithful to that plan.

Every effort was made to be as faithful to the plan set out in Chapter 3 as possible, but this was not possible in every case. However, I was able to gather and triangulate sufficient information to build a credible and robust case study of NCS and FIRS. Tell, a popular Nigerian magazine, published a Special Publication on FIRS in November 2011, titled: A Silent Revolution at the Revenue House. This included interviews with FIRS management and staff and the key stakeholders that interface with the organisation, precisely on the reforms that had taken place in FIRS and the internal and external factors that affected its success. Indeed, many people that I interviewed in FIRS referred me to their interviews in that magazine. However, I still carried out a number of interviews to triangulate information and explore nuances.

NCS, being a paramilitary organisation, has a command and control structure that means that the flow of information can be quite hierarchical. 
Revenue performance data was readily available but the availability of key officers for interviews was variable. Some officers were so intrigued by the research topic that they immediately launched into the interviews. Others preferred to provide written responses to a list of advance questions but their responses had to be vetted by their bosses before they could be released. This caused a delay in some cases, and, in other cases, I could not get formal written responses and had to rely on information supplied "unofficially".

Despite these challenges, I obtained sufficient primary and secondary data to be able to build a credible and robust case study of NCS and FIRS. Table 10 sets out the data-gathering activities that I employed in completing this case study.

\section{Interviews}

The list of people interviewed is shown below. All interviews were conducted in Abuja, Nigeria (unless otherwise shown), over a 14-month period between January 2011 and March, 2012.

\begin{tabular}{|c|c|c|c|}
\hline $\begin{array}{l}\text { Planned } \\
\text { Respondents }\end{array}$ & Actual Respondents & Lines of Enquiry & Tool \\
\hline $\begin{array}{l}\text { Relevant Ministers } \\
\text { and Top Politicians }\end{array}$ & 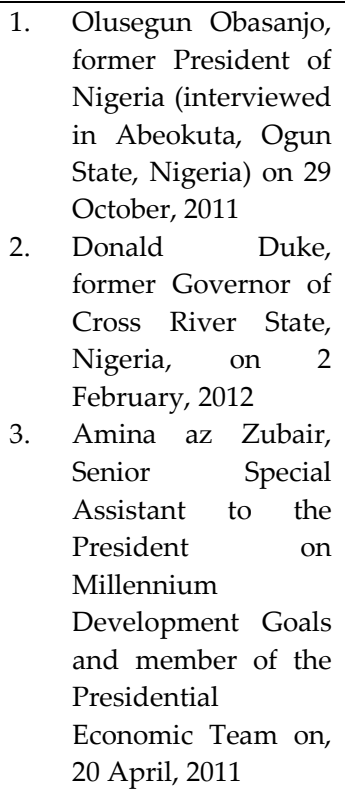 & $\begin{array}{l}\text { - The source of } \\
\text { pressure/ demand } \\
\text { for change/ } \\
\text { political } \\
\text { environment prior } \\
\text { to reforms } \\
\text { If and when a } \\
\text { decision for } \\
\text { improvement was } \\
\text { made, why and } \\
\text { by whom. } \\
\text { How the } \\
\text { conditions for } \\
\text { improvement } \\
\text { came into play. } \\
\text { Hierarchy of } \\
\text { conditions }\end{array}$ & $\begin{array}{l}\text { Semi- } \\
\text { structured } \\
\text { interviews }\end{array}$ \\
\hline
\end{tabular}




\begin{tabular}{|c|c|c|c|}
\hline & 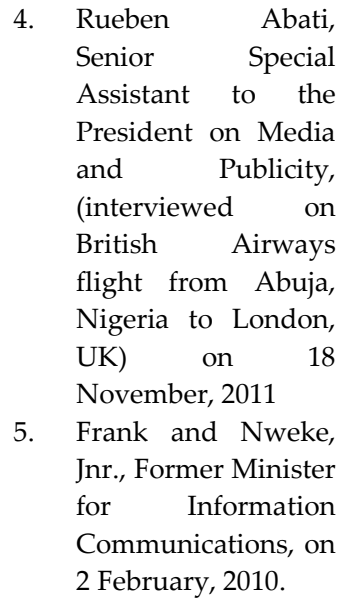 & & \\
\hline $\begin{array}{l}\text { Past and present } \\
\text { Chief Executives }\end{array}$ & $\begin{array}{ll}\text { 6. Ifueko Omoigui- } & \text { Okauru, Chairman } \\
\text { Okaus, on } 7 \text { January } \\
\text { of FIRS } \\
2011\end{array}$ & $\begin{array}{l}\text { - The source of } \\
\text { pressure/ demand } \\
\text { for change. } \\
\text { If and when a } \\
\text { decision for } \\
\text { improvement was } \\
\text { made, why and } \\
\text { by whom. } \\
\text { How the } \\
\text { conditions for } \\
\text { improvement } \\
\text { came into play. } \\
\text { - Hierarchy of } \\
\text { conditions }\end{array}$ & $\begin{array}{l}\text { Semi- } \\
\text { structured } \\
\text { interviews }\end{array}$ \\
\hline $\begin{array}{l}\text { Officers- } \quad \text { Low, } \\
\text { Middle and Senior } \\
\text { Management Level }\end{array}$ & $\begin{array}{l}\text { 7. Osy Chuke, } \\
\text { Coordinating } \\
\text { Director, Corporate } \\
\text { Development } \\
\text { Group, FIRS, on } 15 \\
\text { December, 2011 } \\
\text { 8. Achillies Amawhe, } \\
\text { Director of Internal } \\
\text { Affairs, FIRS, on } 22 \\
\text { December, 2011 } \\
\text { Emmanuel Obeta, } \\
\text { Director } \\
\text { Corporate } \\
\text { Communications, }\end{array}$ & $\begin{array}{ll}\text { External and } \\
\text { Internal Factors } \\
\text { affecting } \\
\text { performance } \\
\text { - } \text { Internal } \\
\text { organisational } \\
\text { and management } \\
\text { arrangements }\end{array}$ & $\begin{array}{l}\text { Semi- } \\
\text { structured } \\
\text { interviews }\end{array}$ \\
\hline
\end{tabular}




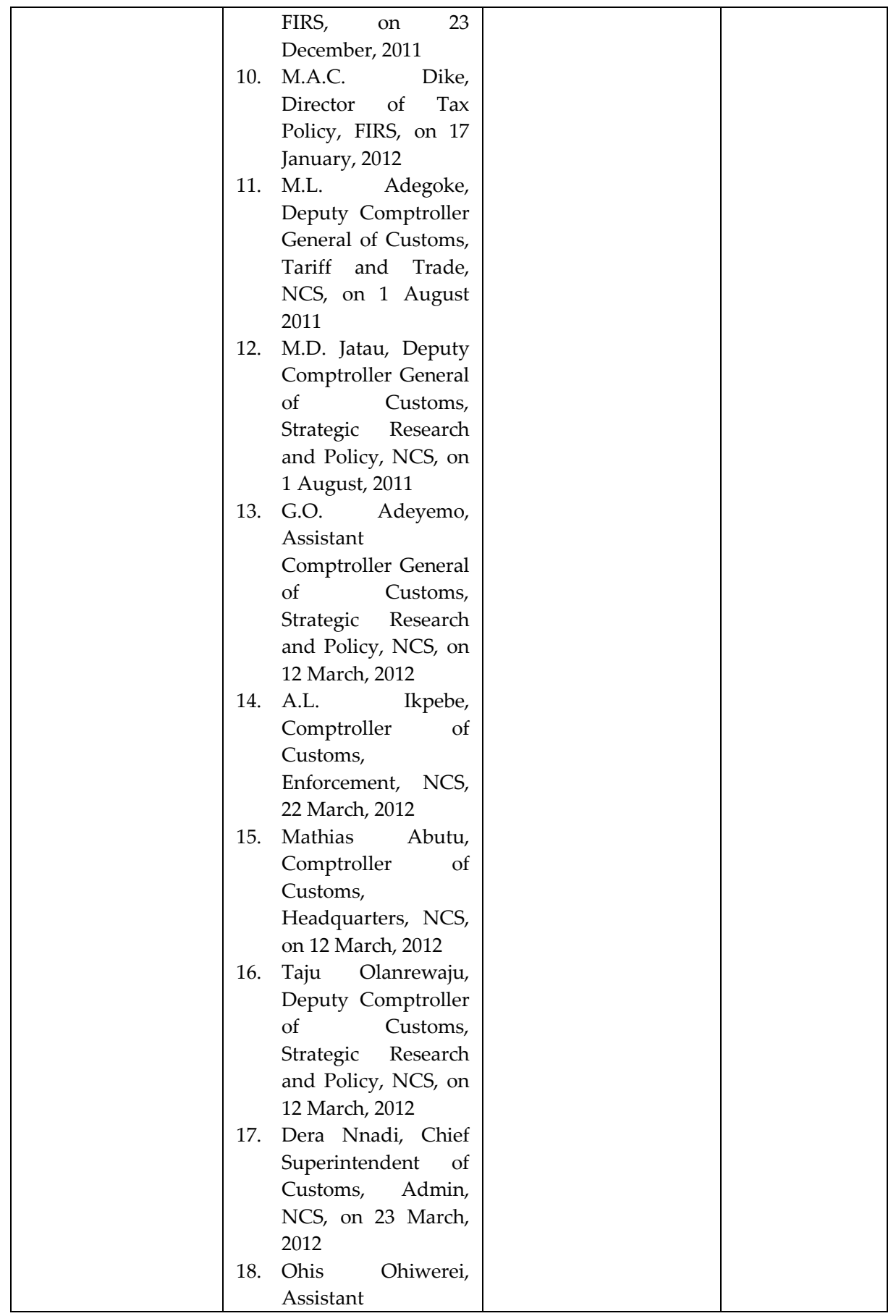




\begin{tabular}{|c|c|c|c|c|}
\hline & & $\begin{array}{l}\text { Superintendent of } \\
\text { Customs, Tariff and } \\
\text { Trade, on } 23 \text { March, } \\
2012 .\end{array}$ & & \\
\hline $\begin{array}{l}\text { Civil Society/Media } \\
\text { Representatives }\end{array}$ & $\begin{array}{l}20 . \\
21 .\end{array}$ & $\begin{array}{l}\text { Jibrin Ibrahim, } \\
\text { Executive Director, } \\
\text { Centre } \\
\text { Democracy and } \\
\text { Development, on } 5 \\
\text { September, } 2011 \\
\text { Soji Apampa, } \\
\text { Director, } \\
\text { Convention on } \\
\text { Business Integrity, } \\
\text { on 2 October, 2011. }\end{array}$ & $\begin{array}{l}\text { - The source of } \\
\text { pressure/ demand } \\
\text { for change } \\
\text { - Hierarchy of } \\
\text { conditions }\end{array}$ & $\begin{array}{l}\text { Semi- } \\
\text { structured } \\
\text { interviews }\end{array}$ \\
\hline $\begin{array}{l}\text { Private sector } \\
\text { representatives }\end{array}$ & $\begin{array}{l}19 . \\
20 . \\
21 .\end{array}$ & $\begin{array}{l}\text { Segun Kadiri, } \\
\text { Manufacturers } \\
\text { Association } \\
\text { Nigeria, on } \\
\text { March, } 2012 \\
\text { Eniola } \\
\text { Women in Cross- } \\
\text { border Trade, on } 14 \\
\text { March, 2012 } \\
\text { Francis Omotosho, } \\
\text { Association } \\
\text { Nigeria Licensed } \\
\text { Customs Agents, on } \\
\text { 14 March, } 2012\end{array}$ & $\begin{array}{l}\text { - The source of } \\
\text { pressure/demand } \\
\text { for change } \\
\text { Hierarchy of } \\
\text { factors }\end{array}$ & $\begin{array}{l}\text { Semi- } \\
\text { structured } \\
\text { interviews }\end{array}$ \\
\hline Donors & $\begin{array}{l}22 . \\
23 .\end{array}$ & $\begin{array}{l}\text { Sola Afolabi, } \\
\text { Director of Business } \\
\text { Environment, } \\
\text { USAID, on } \\
\text { March, } 2012 \\
\text { Anthea Dickie, } \\
\text { Programme } \\
\text { Manager, DFID } \\
\text { Policy Development } \\
\text { Framework, on } 16 \\
\text { March 2012 }\end{array}$ & 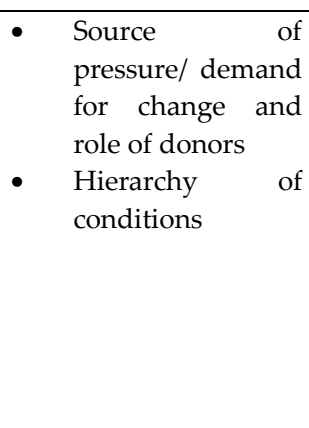 & $\begin{array}{l}\text { Exploratory } \\
\text { and semi- } \\
\text { structured } \\
\text { interviews }\end{array}$ \\
\hline Service Users & & $\begin{array}{lr}\begin{array}{l}\text { Asishana } \\
\text { pioneer }\end{array} & \text { Head, }\end{array}$ & $\begin{array}{llr}\text { - } & \text { Source of } \\
\text { pressure/ demand }\end{array}$ & $\begin{array}{l}\text { Semi- } \\
\text { structured }\end{array}$ \\
\hline
\end{tabular}




\begin{tabular}{|c|c|c|c|c|}
\hline & $\begin{array}{l}25 . \\
26 . \\
27 .\end{array}$ & 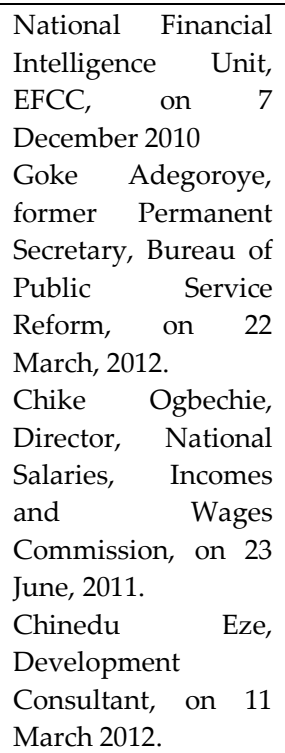 & $\begin{array}{l}\text { for change } \\
\text { - Hierarchy } \\
\text { conditions }\end{array}$ & interviews \\
\hline
\end{tabular}

Table 13: Revenue Administration: Comparison with Methodological Plan - NCS/FIRS

\subsection{Conclusions}

In this chapter I have continued the process of theory-building that started from my literature review through to the case studies on anticorruption and regulatory quality. The present case study, on revenue administration, profiles two organisations that have existed in Nigeria since colonial times. During that period of existence, there have been several waves of reforms in both organisations at various points in time. However, perhaps the most significant changes have been redefining the main purpose of NCS to be revenue generation, and granting full operational autonomy to FIRS.

The internal and external factors that affect performance bear close resemblance with those identified in the case studies on anticorruption and revenue administration in previous chapters, although there are significant 
differences in some cases. These will be explored more fully in the next chapter.

The developing theory that atypical performance is triggered by a desire for change, backed by the ability to bring about that change appears to hold in this case study, although its application differs for FIRS and NCS. For FIRS, there was a clear imperative to raise tax revenue, the government provided the enabling environment for it to happen (through, for instance, granting autonomy to FIRS and headhunting a suitable leader) and giving FIRS the strong legislation that it needs to perform. For NCS, there was a similar imperative to raise revenue from customs services and the government signalled its intentions by changing the primary purpose of NCS from protection to revenue generation. However, given the nature of the work that NCS does, it would have been difficult to bring in a leader from outside for the primary purpose of driving up revenue. Instead, the government appears to have waited for the NCS succession system to throw up an appoint-able reform-minded Comptroller General of Customs, and then appointed him. There is also an ongoing process to repeal and re-enact CEMA to make NCS more fit-for-purpose. While the leader of FIRS was headhunted from among tax experts throughout the society, identifying a potential reforming Comptroller General from within the NCS hierarchy would have been a difficult task. However, the government has recently done something similar in the Nigerian Police Service where it identified an Assistant Inspector General, appointed him as Inspector General of Police ahead of his seniors in rank and retired all the Deputy Inspectors General that were his seniors in rank. This did not happen in NCS and Dikko Inde Abdullahi, the Comptroller General that is currently turning around the NCS, appears to have been a happy accident.

In the case study on regulatory quality in the previous chapter, we had started to explore the concept of the activist political leader working in tandem with an activist organisational leader. The start of the reforms in FIRS under President Obasanjo and the searching out and appointment of Ifueko Omoigui-Okauru at the same time may qualify as an activist political leader combining with an activist organisational leader to drive through reforms. On the other hand, the turn-around of the NCS could be said to have really started in 2009, with the appointment of the current Comptroller General. The President that appointed him, President Umaru Musa 
Yar'adua, would not be described my many as an activist. Instead, the words more commonly associated with him are 'unobtrusive', 'quiet', 'staid' and 'silent' (The Nation, 2010). President Yar'adua died in May 2012 and was succeeded by President Goodluck Jonathan, who himself would not readily be described as an activist. The Director-General of SON, who was appointed by President Jonathan, confirmed that he was not given any specific mandate upon his appointment. However, President Jonathan is an ex-customs officer, and NCS is supervised by a Minister of Finance (appointed by President Jonathan) who can readily be described as a reformer. She had led the Economic Management Team under President Obasanjo and was the main driver of the reforms during Obasanjo's tenure. It is possible that this combination of a president who is an ex-customs officer, a reformer supervising Minister and a progressive Comptroller General is one of the factors in the turn-around of NCS.

Another interesting dimension that is beginning to crystallise in my mind is the impact of reforms in one organisation on a similar organisation. This is particularly the case when one organisation is an institutional member of another organisation's board. SON is a member of the NAFDAC board and the reforms currently going on in SON bear striking similarities to those that happened in NAFDAC. Similarly, the Comptroller General of Customs sits on the FIRS board, and the Chairman of FIRS sits on the NCS board. The reforms in NCS also bear striking similarities to the process that FIRS undertook to reinvent itself. It is likely that the exchange of information and ideas, and the likely offers of help during board discussions would have been a factor in the reforms of SON and NCS.

In the next chapter, we will bring these and other factors together across the three case studies and consolidate our understanding of what works and why. 


\section{Chapter 7 Islands of Performance in a Sea of Underperformance}

The same mother gives birth, but different gods create (African Proverb). ${ }^{47}$

This chapter brings together what I have learnt from the three empirical case studies that I have undertaken. In doing this cross-case analysis, I will stay faithful to the dependent and explanatory variable that I used in conducting the case studies. Eisenhardt (1989, p.540), citing various authors, argues that human beings are notoriously poor processors of information. She lists the tendencies that people have which may obscure analysis as:

- Leaping to conclusions based on limited data;

- Being overly influenced by vividness;

- Being overly influenced by more elite respondents;

- Ignoring basic statistics; and

- Inadvertently dropping disconfirming evidence.

She suggests that these can be countered by selecting pairs of cases and then listing their similarities and differences. This is already the approach that I adopted for the empirical case studies, by looking at pairs of organisations performing broadly similar functions. The second tactic that she suggests for countering the tendencies above is to select categories or dimensions and then look at similarities and differences. This is what I now intend to do, using my dependent and explanatory variable as a basis. In constructing this chapter, I will 'enfold the literature' (Eisenhardt, 1989, p. 533) by comparing my findings with confirming or disconfirming literature to see

\footnotetext{
${ }^{47}$ This proverb, commonly used among the Igbo of south eastern Nigeria, means that although many children can come from the same mother, each child has his own destiny. This is used here in the context of different organisations within the same government and society.
} 
where that places us for purposes of building theory. This is not a rehash of the literature review chapter. Rather, it places relevant literature in the context of my empirical findings.

\subsection{Introduction}

According to Simmons (2009, p. 117), "Analysis and interpretation are perhaps the two aspects of case study research that are written about least". Helpfully, Miles and Huberman have written a substantive and important book focusing solely on Qualitative Data Analysis (Miles and Huberman, 1994), and authors such as Yin (2009), Sayer (2010) and Simmons herself, provide guidance on issues of analysis, interpretation and explanation. Simmons defines analysis as the procedures for organising and making sense of data in order to produce findings and an overall understanding; and interpretation to mean the insights derived from an intuitive, holistic grasp of the data and the insights they reveal.

According to Sayer, 'explanation' is an elastic term that is used to cover a wide range of actions. On the one hand, it should enable us to draw on everything we know to construct a proposition. On the other hand, it is pointless simply to list everything we know in life, without critical comment. That would make methodology redundant. He further argues that any explanation, be it of natural or social phenomena, is incomplete because all knowledge is fallible and the objects of study are undergoing continuous change (Sayer, 2010, p.234). The proposition that all knowledge is fallible is debatable. For instance, there was once a belief that the earth was flat in shape. This has since, in support of Sayer's proposition, been faulted. However, having developed the capacity to view the shape of the earth from outer space, it is unlikely that our current knowledge that the earth is round will be faulted in the future, unless maybe our definition of the word 'round' or 'earth' changes. The same is applicable to our knowledge that every human will die one day. Again, our definition of 'human' or 'death' may change over time, but the evidence that we have, and our cumulative experience since man came into being, makes it safe to say that all humans will die one day. It is on the evidence that we must focus, and our knowledge must necessarily be drawn from existing 
evidence, until there is other evidence to the contrary. On Sayer's second point, I agree that the objects of study change continually and that any study is essentially a snapshot in time. Indeed, in the course of my fieldwork between January 2011 and March 2012, SON acquired a new Director-General who has started the turn-around of the organisation, NCS met its revenue targets for the first time in four years, and the Chairman of EFCC was replaced.

The 'pockets of productivity' literature, as inventoried by David Leonard, puts forward a plethora of propositions. Authors like Leonard (1991), Grindle (1997) and Uphoff (1998) argue that the key factors determining organisational productivity are management and leadership. Bebbington and McCourt (2007) claim that function is more important for productivity than either management or political economy. Grindle and Thomas (1991) and Heredia and Schneider (2002) focus on the process by which efforts to improve performance are undertaken: the more simply it is done, the better its chances of survival. Evans (1995), Kaufman (2003), Leonard (2006) and Bebbington and McCourt (2007) say that the underlying political economy in which an organisation is placed will shape all other causal factors and determine what productivity is possible.

In addition to Leonard's inventory, other authors have identified the reasons for success in the organisations that they studied. These include a satisfactory legal framework, capacity to mobilise resources, supportive central government and appropriate management practices (Olowu, 1992); good pay and transparent recruitment practices (Owusu, 2005); performance management (Waal, 2007; 2008); technology and training, use of information, utilisation of external assistance and ability to deal with government and politics (Uphoff, et al, 1998); and organisational focus, discipline, use of technology and relentlessness (Collins, 2001).

These factors identified in the literature informed the selection of the explanatory variable used in this study. They have been set out as internal and external factors and will form the basis of this cross-case analysis. However, it is important, first, to remind ourselves again of the research question that we are trying to answer: How and why are certain public sector organisations able to achieve atypical performance in dysfunctional environments? In answering this question in this chapter, it is important to 
revisit the dependent variable used in this research (Performance) to see what we have learnt from doing the case studies, before we launch into the explanatory variables.

\subsection{Application of the Dependent Variable}

The Dependent Variable for this study is Performance. In Chapter 1, I had explained that public sector performance is a multidimensional construct that is often viewed in terms of inputs, outputs and outcomes (Mwita, 2000). Because public sector organisations are created to deliver certain outputs (school diplomas, surgical operations, licences, drinking water, etc.), I chose to focus on outputs as the best way of assessing organisational performance (OECD, 2009). I defined the term 'performance' to mean the extent to which a public sector organisation has achieved its predetermined goals with regards to its outputs, given a certain level of inputs. In identifying what the organisation's predetermined goals are, I went to the legislation setting up the organisation and also assessed the organisation's own internal interpretation of its mandate. Therefore, the test that I used was simple: to what extent has the organisation achieved the mandate it was given, whatever that mandate is, given the resources that it has?

In comparing the pairs of organisations for each case study, I have used a set of performance indicators, drawn from the literature in each field, to assess performance:

- Anticorruption: Prosecution to conviction rates (USAID, 2006, p.14; Johnson, 2011, p.62), and amount of money recovered (Bolongaita, 2010, p.17; Johnson, 2011, p.63).

- Regulatory Quality: Extent to which the agency has facilitated the accomplishment of policy goals in the sector (Makhaya, 2002). Therefore I have assessed the prevalence of fake drugs or substandard goods (Parker, 1999; Jalilian, 2006; Brown, 2006)

- Revenue Administration: Actual collection compared to estimated collection potential (Soest, 2010, p.62). 
I will now look at the effect of the performance indicators used on my empirical chapters:

\section{Anticorruption}

The performance of anticorruption bodies is often assessed on their prosecution-to-conviction ratios and the amount of money that they recover from corrupt people. It is recognised that they often have other functions apart from conviction and asset recovery, and these can include civic education, deterrence and tightening systems to constrain the opportunities for corrupt enrichment.

EFCC was entirely comfortable with the performance criteria used to assess its performance. Indeed, it uses the same criteria to measure its own performance and openly publishes data on these on its website.

ICPC, on the other hand, felt that using prosecution-to-conviction rates and amount of money recovered only assesses one of the three main functions under its establishment law. It felt that the good work it does to educate members of the public about the ills of corruption (including inserting civic education and anticorruption into the secondary school curriculum) has not been captured by the performance criteria used. Also, it says that it carries out system studies which look at the procedures used in government establishments to ensure that they are not open to corruption and abuse. They feel that the value of this important preventive work is not captured by the performance criteria used and is difficult to quantify numerically.

While ICPC's arguments may have some merit, it is clear that EFCC also carries out these additional functions of civic education and fraud prevention. ICPC has also not disputed the fact that it should do more on its prosecution-to-conviction rates and asset recovery. I feel therefore that the performance indicators used were fair, particularly as they were drawn $a$ priori from the literature and the mandates of the organisations, as stated in their enabling laws.

However, despite recording impressive figures on the two performance indices used, the Chairman of EFCC, Farida Waziri, was relieved of her job by the President in November 2011. Waziri has always had a difficult 
relationship with the media and the international community, who felt that EFCC's effectiveness had diminished under her leadership (Nigerian Tribune, 2011b). Various prominent individuals and groups welcomed her removal, including lawyers, anticorruption campaigners, human rights activist and civil society groups (Vanguard, 2011b). Her removal was linked to the dissatisfaction of the international community with her style of leadership. As if to confirm this, the United States ambassador to Nigeria publicly welcomed her removal a fortnight after her sacking (Nigerian Tribune, 2011c).

The point to be made from Waziri's sacking is that, sometimes, delivering on mandates is not enough. Just as is the case in fighting crime, dealing with the fear of crime is often as important as reducing the actual incidence of crime. When public confidence is lost, the agency struggles to justify its actual performance. An effective agency is one that combines legitimacy, credibility and transparency (Brown, 2006). When an organisation loses credibility, public support and political backing, performance statistics pale into insignificance. This puts the OECD's almost-exclusive focus on the delivery of outputs in context.

\section{$\underline{\text { Regulatory Quality }}$}

The basic function of regulatory agencies is to regulate the activities within their mandate areas. Therefore, their performance is often assessed on their ability to effectively carry out the regulatory functions that they were established to carry out (Makhaya, 2002).

NADFAC and SON did not have issues with the performance indicator used to assess their performance. Again, it is the same indicator that they use to measure their own performance: reduction in the prevalence of fake and substandard drugs; and reduction in the prevalence of fake and substandard goods. An issue that SON raised was that some of the crimes against its Establishment Act (such as selling counterfeit designer goods) are seen by members of the public as "victimless crimes". This is different from the way that the public would view fake or substandard pharmaceuticals. Additionally, in a developing economy, the poor would want access to 
cheaper building material, tyres and electronics, and would consciously accept the risk of a lower-quality product, rather than being completely unable to afford a good quality version (Chinafrica, 2011). SON therefore argues that NAFDAC enjoys greater instinctive public support than it does and that SON's job is more difficult. Also, NAFDAC is concerned with the discrete areas of food and drug regulation, while $\mathrm{SON}$ is tasked with regulating everything else.

Additionally, SON points to the role of the Nigerian Customs Service and says that if the substandard goods are not allowed into the country in the first place by the NCS, then SON's job would be easier. This is a somewhat odd argument as SON has operatives at the ports carrying out joint inspections with sister agencies like NCS, NAFDAC and the Nigerian Drug Law Enforcement Agency. Perhaps the most important point raised was that, as a policy of government, when fake pharmaceuticals are seized, they are immediately destroyed. On the other hand, when fake goods are seized, they are auctioned off and therefore find their way into the market. Therefore, institutional issues do play a role here.

While SON's clarifications are important to bear in mind, the organisation itself admits that Nigeria is one of the biggest markets for substandard goods in the world. As an example, by SON's own admission, more than $90 \%$ of the goods entering the country in shipping containers are fake or adulterated (Guardian, 2011). The Director-General cites a 2011 baseline study conducted by SON that states that $85 \%$ of consumer goods in the Nigerian market are counterfeit. While the argument about public attitudes helps to put the issues into context, SON does exist to ensure that Nigerians are protected from fake and substandard goods and it is struggling to do so.

The issue about public attitudes is an important one. However, it is likely that if SON does more to educate the public about the dangers of substandard building materials (and the increased risk of collapsing buildings), substandard vehicle parts (and the increased likelihood of brake failure) or substandard electronics (and the increased likelihood of explosions or electrocution), public attitudes will start to change. SON is only now beginning to do these. 


\section{$\underline{\text { Revenue Administration }}$}

On the face of it, measuring the performance of revenue collecting organisations should be straightforward: a simple comparison between expected collection and actual collection (Soest, 2010). However, there are nuances to consider. For instance, we have not, in this study, explored how the revenue collection targets are set in any great detail. The targets set can be influenced by the price of oil on the international market, import duty waivers, revisions of the prohibition list, historical organisational performance, a suspicion of underreporting of collection figures, or simply the application of an annual incremental percentage increase. Some of these could explain the big jumps in certain years, followed by a more realistic target the following year. NCS targets went from N347 billion in 2008, to N650 billion in 2009, and back to N561 billion in 2010, before progressing more smoothly to N596 billion in 2011. FIRS's target more than trebled from N1304 billion in 2005 to N3054 billion in 2006. It came back down to N1753 billion in 2007 and progressed more smoothly upwards since then.

FIRS was entirely comfortable that its performance should be judged on its performance against revenue collection targets. Indeed, Mr Osy Chuke of FIRS said "The most singular index of performance is how much money we collect" (Tell, 2011, p. 16).

The issue of judging performance was not so straightforward in NCS. While NCS recognises that the law guiding its operations, and government pronouncements, make NCS's primary function the collection of revenue, the service itself does not necessarily see its main function in that way. Some of the NCS officers that I interviewed (as well as NCS's donors and partners) felt that their primary function is the protection of society by stopping the import and export of prohibited items, stopping Nigeria from being a dumping ground for fake and substandard goods and contributing to the security of the nation. Some NCS officers also pointed to the lack of clarity from different arms of government about what its proper role should be. The Ministry of Finance (NCS's supervising ministry) emphasises revenue generation; the Ministry of Trade and Integration emphasises trade liberalisation; and the Ministry of the Interior emphasises security and the protection of borders. 
While it is important to consider the issues raised by NCS, the governing law makes NCS's primary purpose revenue generation. Until that law is changed, there is no other legal instrument to go on. It may also complicate matters if we were to attempt to determine how much of SON's underperformance can be blamed on the auctioning of goods seized by NCS, the veracity of allegations by businesses that NCS officers routinely collect bribes to clear goods at the ports, or the rising levels of insecurity in the country as a result of arms and ammunitions brought in through porous borders. It is for these reasons that I believe that the performance indicator used has been appropriate and proper. For the first time in 4 years, NCS exceeded its target in 2011 and is planning to sustain that performance. It therefore suggests that at least the top hierarchy of NCS similarly considers meeting revenue targets to be of overriding importance.

It is important, at this point, to revisit Sayer's proposition that objects of study change continually. At the start of the fieldwork for this study in January 2011, NCS had failed to meet its collection targets for 3 years in a row. Using performance data from the Office of the Accountant General of the Federation and the Budget Office of the Federation for 2005 to 2009 (the period first used in developing my methodology for this study and selecting typical and atypical performers), classifying NCS as an underperforming agency was straightforward. However, the reforms instituted by the new Comptroller General of Customs appears to be beginning to bear fruit, but it is difficult to be categorical about this since NCS has only met its targets for 1 of the last 4 years. NCS is still a long way from sustained atypical performance over 8 years, the period of assessment used in this study to assess sustainability. However, the signs are good and the Comptroller General has time on his side.

In summary, we have needed to focus on the performance statistics of these organisations in other to typify and differentiate them for purposes of comparison. However, in studies of human phenomena, numbers and statistics do not tell the whole story about an organisation in its real-life context (Yin, 2009, p.18). It is the application of explanatory variables and the contextual conditions in which they are applied that illuminate the process of change in those organisations. It is to these that I next turn. 


\subsection{Application of Explanatory Variables}

The explanatory variables for this research are set out as various internal and external factors that have the potential to affect the dependent variable. I will now examine how each of the factors may have shaped performance across all the case studies.

\subsubsection{Internal Factors}

Internal factors are those factors that are often within the control of the organisation, although it is recognised that there is often interplay between internal and external factors. For instance, the level of funding that an organisation is able to secure may depend on the level of political and policy support that it enjoys (Leonard, 2008).

\section{Leadership}

Leadership matters, both at the political and organisational levels (Leonard, 1991; Grindle, 1997). Leadership can be defined as the capacity of someone to direct and energize the willingness of people in social units to take actions to achieve organisational goals (Rainey, 1991, p. 157). The reforms at EFCC, NAFDAC and FIRS were initiated by an activist President (Tendler, 1997) who tied underperformance in all three functions to corruption. He was already a dedicated anticorruption activist (a co-founder of Transparency International) before he even came into office. People who worked directly with President Obasanjo describe him thus:

[...] And that is why whatever people say about Obasanjo, that man has many qualities that are unNigerian (Akunyili, 2011).

You know 'Baba' is special (Omoigui-Okauru, 2011).

That is why I said that, in fairness to Obasanjo, he allowed people to do what they felt was right (Lamorde, 2010). 
That man was full of a lot of convictions that he could do something for his country (Zubair, 2011).

While describing, say, an American as being 'un-American' may be viewed as derogatory, Akunyili's statement that Obasanjo has many qualities that are "un-Nigerian" was meant as a compliment. Upon assuming office in 1999, the first bill that he sent to the National Assembly was an anticorruption bill that he personally wrote by himself. ${ }^{48}$ All of these antecedents mean that Obasanjo could be described as an 'atypical President'. He has many critics, particularly those that accuse him of choosing the laws that we wants to obey, and illegally attempting to elongate his tenure (a claim that he has consistently denied). However, as far as the organisations I have studied are concerned, he appears to have been more a force for good than otherwise. As Tendler points out, an "activist central government" has perhaps an unrivalled ability to bring about change (Tendler, 1997, p.15). Obasanjo appears to have deployed this ability to its maximum in the areas in which he was interested.

The 'activist political leader' then 'headhunted' similarly 'activist' organisational leaders to drive the reforms in these agencies. However, Goke Adegoroye, pioneer Director General (and later Permanent Secretary) of the Bureau for Public Service Reforms, explained to me in my interview with him on 22 March, 2012, that this 'head-hunting' is not as direct as President Obasanjo may have made it appear. What happens is that the President specifies the type of person that he is looking for and various people start the search for someone that matches the criteria set by the president. The President then chooses someone from the list of people that various people present to him. Adegoroye explains that in the case of his own appointment as Director General of the Bureau of Public Service Reforms, the President had directed that the person to be appointed should be "a public sector specialist, and a man or woman of impeccable character and integrity, who is reform-minded and broad minded". Adegoroye explained that, having specified the kind of person that he was looking for in each case, there was then an element of unpredictability about whom the President eventually chose from the lists presented to him. Ribadu was

\footnotetext{
${ }^{48}$ My interview with President Obasanjo on 29 October, 2011.
} 
sourced for the President by Kanu Agabi, the former Attorney General of the Federation; Akunyili was sourced by Onaolapo Soleye, Obasanjo's close friend; and Omoigui-Okauru was sourced by Ngozi Okonjo-Iwealla, Minister of Finance.

The reforms in EFCC and NAFDAC could be said to have been initiated by chief executives that were daring, risk-taking and media savvy - the socalled 'charismatic leader' (Leonard, 1991) who brings about change largely through the force of his own character. This approach was described by Ribadu as a "big bang" approach that was necessary to fight deep-rooted graft and fraud. He defended this approach against criticisms that he was "a cowboy, using commando-style raids and seeking the limelight" and justified the psychological impact of high-profile operations (Ribadu, 2010, p.132). Those leaders then left (or were asked to leave) the organisation and went on to pursue political careers, unsuccessfully. They were replaced in each case by seemingly less charismatic leaders whose focus were on building systems and institutionalising earlier organisational gains.

The Chairman of FIRS, on the other hand, had focused from the start on building systems and managing change. Her approach has been planned, systematic, measured and incremental - a 'silent revolution' (Tell, 2011). In my view, this approach does not make her any less charismatic or daring. Under her watch, FIRS has sued the government several times on issues of principle and law. In environments with an overbearing central government, such as Nigeria, this is suggestive of courage. She also appears to have fought corruption in the tax system fearlessly and with passion. However, she has carefully ensured that the media spotlight is more on FIRS than on its leader. It is very likely that, among ordinary Nigerians, she is not as well known as Ribadu or Akunyili. This may contribute to the explanation of the low ratings that FIRS has in opinion ratings such as those of NOI Polls.

In the three well-performing organisations (EFCC, NAFDAC and FIRS), the law setting up the organisation specifies the qualifications and pedigree that the leader should have. No specific qualifications were specified for the leaders of SON and NCS to have. In ICPC, the Chairman is required to be a person who is qualified to be appointed a judge. However, the practice of appointing retired senior judges has been seen by many as a major 
hindrance to the performance of the organisation. This particular point about specifying the qualifications and pedigree required of leaders is currently underdeveloped in the literature. For instance, it is not covered at all in Leonard's inventory of the 'pockets of effectiveness' literature.

In each well-performing organisation, the leader that initiated the reforms was given a specific mandate by the political class. This does not appear to have been the case in SON and NCS and the turn-around that have started in those organisations appear to have been driven by the chief executives' own self motivation. Leonard (2008) highlights this point and argues that a clear set of goals gives the organisation strong legitimacy. I will return to this point when I discuss the clarity of expectations as part of the external factors.

In my view, the major issue arising out of a consideration of the effect of leadership on an organisation is the extent to which an individual can overcome negative institutions and the prevailing adverse political economy in which they are placed by the sheer force of their will and character. John Stuart Mills (1987, p.22) clearly sets out the arguments for and against. Those who subscribe to a doctrine of Necessity assert that human volitions and actions are necessary and inevitable. This is similar to the rational choice theory put forward by institutional theorists (Hall and Taylor, 1996; Sturzenegger and Tommassi, 1998; Bevir and Rhodes, 2001). Others subscribe to the view that will is not determined, like other phenomena, by antecedents, but determines itself, and that volitions are not always the effects of necessity or inevitability. Mills, rightly in my view, points out that human actions are

[...] never (except in some cases of mania) ruled by any one motive with such absolute sway that there is no room for the influence of any other. The causes, therefore, on which action depends are never uncontrollable, and any given effect is only necessary provided the causes tending to produce it are not controlled (Mills, 1987, p. 25).

Looking at all six cases studied in this research, I am persuaded that the individual can overcome a dysfunctional environment, institutional 
constraints and the prevailing political economy in which they are placed, by the sheer strength of will and the example of character. The strength of will and the example of character demonstrated by President Obasanjo is a common thread running through all three atypical organisations. The institutional constraints against fighting corruption, improving drug regulation and increasing tax revenue in Nigeria were daunting. These include history, culture, the 'resource curse' and the interests of the powerful elite. In each case of atypical performance, the prevailing political economy was adverse. To give a few examples:

- With regards to historical institutional constraints to fighting corruption, Nigeria was the most corrupt country in the world at the time it celebrated the $40^{\text {th }}$ anniversary of its independence (Transparency International, 2000);

- Culturally, the norm of giving and accepting gifts to obtain services that should normally be provided by the public sector is not conducive to an anticorruption effort (Rose-Ackerman, 2006); and

- In mineral-rich countries, people are generally averse to paying taxes and this is made more difficult where, as in Nigeria, there is a poor record of the delivery of public goods in return for taxes paid (Shaxson, 2007). It is within this institutional setting that the effort at improving revenue from taxes was undertaken.

Despite these constraints, President Obasanjo was able to select, motivate and empower carefully-selected leaders to achieve atypical performance, regardless of the dysfunctional environment within which they had to function. According to Bardhan, people like Obasanjo, Ribadu, Akunyili and Omoigui-Okauru are usually motivated by powerful impulses within the state affecting the individual, fuelled not merely by motives of selfaggrandizement but quite often by national interest.

“[...] the leadership genuinely considers itself as the trustee of the nation's most deeply held normative aspirations, and in a world of international military and economic competition, these aspirations often take the form of striving for rapid economic growth (Bardhan, 1984, p. 34). 
Alexandra Gillies (2007) had listed the factors that may have motivated President Obasanjo to undertake the reforms as: personal prestige (to be seen as an international statesman), national prestige (to project the image of Nigeria abroad), seeking debt relief, domestic legitimacy, and international pressure. However, it seems to me that she missed out one crucial consideration, often missed out by Western commentators on improvements in the developing world: Patriotism. One of the characteristics that each of the leaders of the well-performing organisations appear to share is a willingness to put their country first and subordinate any private pecuniary interests that they may have been tempted to have.

In conclusion, leaders can play a catalytic role in bringing about conditions that did not previously exist. This is particularly important where, as in dysfunctional environments, it is necessary to overcome institutional conditions to attain a desired outcome.

\section{Management}

Management, in the context of this research, is the totality of attributes needed to run an organisation. From a synthesis of the literature, I have focused here on funding, recruitment processes, performance management and pay and conditions of service.

\section{Funding}

The ability to mobilise adequate resources is a key ingredient for atypical performance (Leonard, 2008, p.15). Levels of funding and budgetary provision differed significantly between the cases studied in this dissertation, with the well-performing organisations receiving higher funding than their comparator organisations. This raises the question as to whether the atypical organisations performed well because they were better funded, or whether they were better funded because they had demonstrated results which then attracted greater funding from government and donors. The position differs from case to case and there is no one right answer. 
Where the government has a prior agenda that it wants to address, such as money-laundering (EFCC), reducing the prevalence of fake drugs (NAFDAC) or improving tax administration (FIRS), it would usually provide the level of funding needed to get the job done. My empirical studies suggest that this level of funding would usually be higher than that normally provided to similar organisations. EFCC has its own training academy (ICPC does not); EFCC operatives confirmed that operational expenses needed to conduct investigations were never lacking, while ICPC staff claimed that they sometimes had to use personal resources to fund operations; EFCC has the latest information and communication technology systems, including crime-fighting software, while ICPC does not. Between 2008 and 2010, budgetary provision to EFCC rose from N4.1 billion to N9 billion. On the other hand, the provision for ICPC fell from N3.5 billion to N1.9 billion. The case of EFCC is suggestive of the proposition that where the government has an imperative to make a change, it would usually make available the resources required to achieve that change.

NAFDAC has several well-equipped laboratories and even has hand-held equipment with which it can instantly determine the genuineness of a drug in a pharmacy. SON laments that it does not have a single functional laboratory and the Director-General did not think that it was sensible to invest in information technology equipment while the office accommodation remained entirely unsuitable.

Similarly, the government has funded FIRS so well that the funds to carry on normal operations is not lacking. Office buildings have been refurbished and new ones acquired, the most sophisticated information technology software and hardware are in use, and there is a massive capacity-building effort for staff. The government allows FIRS to keep $4 \%$ of all the non-oil revenue that it collects (N185 billion in 2011), while it allows NCS to keep $7 \%$ of what it collects form customs and excise duties (N52 billion in 2011). Therefore, FIRS gets more than 3-times the funding that NCS receives. This difference in available resources is evident in the adequacy of office accommodation and equipment, and the capacity to access the media, deploy technology, and build the capacity of staff.

Leonard (2008) is of the view that the ability to mobilise resources depends on competent and honest resource management. While the atypical 
organisations that I studied would be suggestive of honest and competent resource management, given their strong focus on anticorruption, my empirical work does not fully support this proposition. It is possible to mobilise resources even in the absence of competent and honest resource management. Indeed, ICPC narrated an instance to me where the Senate attempted to appropriate money for computers that ICPC did not need, possibly so that some Senators can gain the corrupt benefits of supplying the computers. ICPC refused the offer. Instead of competent and honest resource management, my empirical finding is that organisational effectiveness can often be a precursor to the ability to attract and maintain the required level of funding. Given that governments never have enough money to do all the things that they want to do, and there is always competition for scarce resources, decision makers will often direct resources to areas in which they are likely to have the most impact. Consequently, they will often fund, continue to fund, and increase funding for, those organisations that are doing well (or have the potential to do well) and give the others just enough resources to keep them ticking over (Leonard, 2008). This would usually mean that an organisation that wishes to attract improved funding may first need to demonstrate a certain capacity and sense of purpose (Esman and Uphoff, 1984). This is important to consider where there does not appear to be a clear government agenda to improve a particular function. As the appetite to improve $\mathrm{SON}$ is not clearly apparent in government, SON may somehow need to demonstrate some results in order to come to the attention of policy makers. This may mean realigning its use of available resources to focus it more on outputs than patronage and study tours of questionable use.

\section{$\underline{\text { Recruitment Process }}$}

Recruitment that is open, transparent and not used for the purpose of patronage has a significant effect on how an organisation performs (Leonard, 1991; Grindle, 1997, Owusu, 2005). In the well-performing organisations that I studied, there is a sense among staff that they have been selected on merit and competence, despite occasional allegations that certain senior officers were given special privileges to nominate family members and friends for recruitment. Staff recruited through an open and 
competitive process possess a certain level of confidence and exude a sense of moral authority when undertaking their duties (Owusu, 2005). Findings from my empirical work suggest that open, transparent and merit-based recruitment is one of the contributing factors in the attainment of atypical performance. However, the underperforming organisations follow the same public service rules requiring them to recruit in an open and transparent manner. Therefore, it is not enough to introduce a set of rules or procedures for hiring staff. More important, is that recruitment is primarily for the purpose of improving performance, rather than for patronage or rents.

\section{Performance Management}

Performance Management can be effective even in dysfunctional environments (Waal, 2007). In all the atypical organisations, there is a strong focus on performance management, individually and departmentally, which appears to be lacking in the underperforming organisations. In the atypical organisations, good performance can attract a financial bonus, an opportunity for overseas training (and the estacode that comes with it), or an act of public recognition. NCS has started to introduce elements of performance management, initially at organisational level. It has not yet cascaded down to departments, units and individuals. As with open and transparent recruitment processes though, it is not enough to introduce performance management systems. The abuse of the Annual Performance Evaluation Report (APER) system in the Nigerian civil service is testament to this fact. The APER system is manipulated for ethnic, tribal, religious and other primordial purposes (Olaopa, 2009). Therefore, the key issue with performance management is not its existence but the way in which it is implemented and used to facilitate the delivery of outputs.

\section{Pay and Conditions of Service}

Owusu (2005) argued that pay is a key determinant of organisational performance, and that the better-performing organisations were better remunerated than the underperforming ones. This proposition has not been 
supported by my empirical work. In Nigeria, the pay of public sector workers is regulated by the National Salaries, Incomes and Wages Commission. This means that for each pair of organisations studied, pay is similar. Therefore, where two organisations performing similar functions are on similar pay scales, my study offers no evidence that pay is a key determinant of organisational performance. However, where organisations are allowed to retain part of the revenues that they collect, like in the case of FIRS and NCS, the ability to use this to motivate staff performance could be a contributing factor for atypical performance. NAFDAC and SON retain portions of their internally generated revenue, although ICPC has said that this practice breaches the provisions of the 1999 constitution.

\section{Technical Capacity}

Possessing the required technical capacity to deliver on outputs is vitally important in achieving atypical performance. A tax administrator needs training on tax, an anticorruption officer needs training on investigation and detection, and a regulator needs the skills to be able to test products for conformity (Cohen, 1993; Meagher, 2002; Boesen and Therkildsen, 2005; Soest, 2009). While generic training adds value, there is a need to focus first on building the core competencies necessary to deliver organisational mandates. Without the core skills, the employee is akin to a carpenter who can describe a hammer but is unable to use one.

FIRS, before the current reforms, had officers who had been promoted to tax inspectors without any training on tax whatsoever. Similarly, the competence of SON officials to carry out their basic functions is severely limited. This is despite the fact that officers attend all sorts of training programmes at home and abroad. Many Nigerian civil servants spend their time shopping for training courses that they can attend abroad. The content of the training is often not a major consideration. Rather, it is an opportunity to claim generous duty tour allowances, travel the world and shop. Where the primary purpose of attending training is to augment wages, rather than to learn something that will help to deliver outputs, that training is often of little real benefit to the organisation. Building technical capacity is 
important. However, the content and purpose of the training and the way it is used to raise organisational performance is even more important.

The atypical organisations I studied have intelligently employed various means, techniques, methods and capabilities to enhance their performance. They have all embraced modern technology and have employed them to great effect. Officers in the three atypical organisations appear to be far more computer-literate than those in the underperforming organisations, and the well-performing organisations have developed software and hardware to track corrupt transactions, test pharmaceutical products on the spot and obtain real-time information from revenue collecting banks. ICPC, SON and NCS all appreciate the need for them to embrace technology more, and are already taking steps to do so. Technology is a key ingredient in atypical performance. However, as is the case with other key ingredients, investing in technology is not enough. SON and ICPC (as well as FIRS before the current reforms) admitted that, until recently, computers on the tables of senior officers were mere ornaments and that many of the officers did not even know how to switch them on. It is important that technology directly contributes to the attainment of organisational goals. The public sector environment in developing countries is littered with expensive investments in technology that have never worked. Sometimes, the primary purpose of making that investment is corrupt enrichment, rather than facilitating organisational improvement.

\section{Public Support}

It is important for there to be a resonance between organisational goals and approaches and public expectations (Tendler, 1997, p.137). As was the case in EFCC under its last Chairman, when public support is lost, actual verifiable performance data pales into insignificance. However, this public support only needs to be in the context of legitimacy, credibility and consistency (Brown, 2006). The public does not actually need to support the activity (like paying taxes in the absence of a social contract), they just need to accept that the tax collection activities are being done accountably, transparently and consistently (Parker, 1999; Jalilian, 2006). Additionally, there is a job to be done to educate the public about things that they may not 
ordinarily support an effort about. For instance, $\mathrm{SON}$ is now educating the public that manufacturing substandard building materials is not a victimless crime, as it can lead to building collapse and death. The same is the case for fake vehicle brake pads or substandard electronics.

Good media relations are vitally important. Through the media, an organisation wins public support for its cause. This public support can help to insulate organisational leadership from adverse political pressure. It can also improve an organisation's chances of mobilising required resources, and can create a sense of pride in its officials (Tendler, 1997, p. 137). In my view, this point is currently underdeveloped in the literature, and is crucial for understanding how to avoid what Pranab Bardhan (1984) termed "the infant mortality of reforms". Importantly though, in order to maintain public support, the organisation must demonstrate tangible benefits that the populace can see and touch, beyond any rhetoric. Indeed, unless the organisation demonstrates these tangible benefits, public support can be lost very quickly. Once credibility is lost, it can be very difficult to regain. EFCC built its credibility on the arrest of high-profile individuals that were previously deemed 'untouchable'. The image of the Inspector General of Police in handcuffs surrounded by EFCC officials probably left an indelible mark in the consciousness of many Nigerians and gave real meaning to the EFCC mantra of 'No one is above the law.' The sealing of major markets, such as the Onitsha Headbridge Market, where fake drugs were openly sold, also made Nigerians to sit up and take notice of NAFDAC. The fact that the Inspector General of Police was Ribadu's boss (since Ribadu was a serving policeman even as head of EFCC) and the fact that Akunyili was from the state where the market was located and many of the counterfeiters were from the same tribe as she is did not go unnoticed. These helped to build credibility in the eyes of the public and gave their media campaigns resonance with the public.

\subsubsection{External Factors}

External factors are those that are not directly within the control of the organisation. However, it is accepted that internal factors (e.g. leadership of 
the organisation) can also affect the external factors and help to shape policy, overcome institutional constraints and clarify expectations.

\section{Political and Policy Considerations}

In reviewing the literature on 'pockets of effectiveness' in Chapter 2, I had discussed the proposition advanced by some authors (Bebbington and McCourt, 2007; Leonard, 2008) that the underlying political economy context in which an organisation is placed will ultimately overcome and shape all other causal factors and determine what productivity is possible. I will now discuss this proposition in the context of my empirical work.

The political and policy environment in Nigeria has changed dramatically over the last 8 years. President Olusegun Obasanjo started his second term in office in 2003, which is when it could be said that the substantive reforms of organisations started (Olaopa, 2010). The reforms he initiated were probably driven by a number of considerations: patriotism, necessity, an anticorruption pedigree, intra-elite competition, the need to grow the economy, pressure and support from the international community, and the intention to leave behind a legacy of good governance. However, the legacy was severely tainted, in the eyes of many, by President Obasanjo's alleged attempt to illegally extend his mandate by seeking an unconstitutional third term in office. Opponents of what became known as the "Third Term Agenda' accused Obasanjo of using state apparatus, particularly the EFCC, to cow opponents into supporting the agenda. EFCC's Ribadu was seen by many as a willing tool in that enterprise and it similarly tainted Ribadu's legacy in EFCC in the eyes of many.

In 2007, President Obasanjo was succeeded by President Umar Musa Yar'adua. Improperly for a serving public official, Dora Akunyili ran President Yar'adua's election campaign while still the Director-General of NAFDAC. President Yar'adua placed a very strong emphasis on 'rule of law' and 'due process', which meant that a number of the reforms that were initiated by President Obasanjo began to be reversed. This was on the basis 
of accusations that his predecessor had not always respected the letter and spirit of the law. This made 'big bang' approaches such as those used by Ribadu at EFCC vulnerable, and Ribadu was eventually removed. Conversely, Dora Akunyili was made Minister of Information and Communication by President Yar'adua and she left her NAFDAC post after 7 years. President Yar'adua had a reputation for personal honesty. He was the first governor in Nigeria to publicly declare his assets and was also the first president to do so. ${ }^{49}$ President Yar'adua died unexpectedly in May 2010 and his deputy, Goodluck Jonathan, became President.

Between May 2010 when President Jonathan assumed office as Acting President and May 2011 when he won the presidential elections in his own right, he stated that he would continue with President Yar'adua's programmes and approaches. He indeed retained Dora Akunyili as Minister but also made it possible for Ribadu, who had been in exile when President Yar'adua was alive, to feel safe enough to return to Nigeria. From May 2011 when he was sworn in as President, following his election victory in the April 2011 elections, he has charted his own course. Ribadu ran against President Jonathan in April 2011 and lost. He has since accepted to serve on a Petroleum Revenue Special Task Force set up by the Jonathan government. Akunyili resigned her ministerial appointment, joined an opposition party and ran for Senate. She also lost.

Ifueko Omoigui-Okauru of FIRS appears to have steered clear of politics and has served under all three presidents. By May 2012, she would have completed her eight-year tenure without much controversy and the diversion that active participation in politics brings to a public official. Her reputation would also have been unsullied by the mudslinging that comes with political contest. However, as is usual with holding public office in Nigeria, there have been some allegations of wrongdoing on the part of

\footnotetext{
49 Wikipedia, downloaded from the internet on 20 March 2012, at http://en.wikipedia.org/wiki/Umaru_Musa_Yar'Adua.
} 
Omoigui-Okauru. Nevertheless, there do not appear to be much substance in them and she has gone to court to protect her reputation (Economic Confidential, 2010a). She has also not been charged with, or prosecuted for, any alleged misconduct by any government agency, or investigated by the National Assembly.

Political and policy support, including autonomy and freedom from adverse political interference, are vitally important (Leonard, 2008). The atypical organisations I studies have, to varying degrees, been allowed the freedom to challenge the status quo, without fear of reprisals. They have received political backing at the highest levels and have all confirmed that successive Presidents never attempted to manipulate, distort or adversely influence their work (Ribadu, 2010, Akunyili, 2011; and interviews with Omoigui-Okauru and Obasanjo). However, in EFCC's case, allegations persist that President Obasanjo used the organisation to terrorise political opponents, and that President Yar'adua, under Farida Waziri's leadership, used the EFCC to shield some allegedly corrupt individuals (Human Rights Watch, 2011). Although the Human Rights Watch report raised a number of valid questions, it provided little explanations. I could find no corroborating evidence for a number of the assertions made and am constrained to believe that the report was not objective and may have been aimed simply at finding fault. It is, however, not impossible that Ribadu and Waziri may have felt the need to support the agenda of the government that appointed them, without necessarily being overtly asked to do so. Therefore, as with other important factors, having de jure autonomy (autonomy in law) is not enough. More important is how that autonomy is used in practice. Usually, in practice, the extent of de facto autonomy (autonomy in fact) is often less than the extent of de jure autonomy because of political and other constraints (Laegreid, Verhoest and Jann, 2008).

In the underperforming organisations, the government seems to have largely ignored them and left them to their own devices. President Obasanjo felt that the work of NAFDAC was more important than that of SON, and 
that it was unreasonable to have expected him to reform every agency of government in the time that he had. He referred me to the fact that there are political dimensions to reforms and that you have to choose your battles. President Obasanjo drew an anticorruption thread through the areas that he chose to focus on, and felt that theft from the public treasury is corruption (EFCC and ICPC), dealing in counterfeit and substandard goods and pharmaceuticals is corruption (SON and NAFDAC) and pocketing tax payments rather than paying then into the treasury is corruption (FIRS and NCS). In the prevailing circumstances in 2003/4, he felt that the country needed something different from what the ICPC could provide, that focusing on NAFDAC was more important than focusing on SON, and that FIRS needed to be reformed and NCS reoriented. President Jonathan was allegedly not even aware that the tenure of the Director-General of SON had expired more than two years ago, until it was brought to his attention by someone who was interested in the position. Since the second Chairman of ICPC retired late in 2010, the Commission still does not have a substantive Chairman as at March, 2012. Various attempts to appoint a Chairman have been unsuccessful, for one reason or the other, and the organisation has consequently suffered instability and a lack of dynamic leadership.

In the appointments of Akunyili and Omoigui-Okauru, President Obasanjo seems to have been willing to go outside the normal public service compensation arrangements in order to induce his preferred appointees to take the job. In his interview with me on 29 October, 2011, he described how he helped Akunyili to own her own home, "not through government." Omoigui-Okauru describes a similar discussion:

There were two issues he said were issues for me. One was salary. The other was that this was the first time I was going to work in the public service. He said I could cope with the public service once I had a hang of it and if I had issues with salary, I 
should come back and let him know (Tell magazine, 2011, p. 10).

In my interviews with Omoigui-Okauru, Ribadu and Akunyili, OmoiguiOkauru was the only one to highlight the need for a public appointee to be financially secure if she is not be tempted to be corrupt. While it is not clear whether or not she went back to President Obasanjo on the issue of salary, I believe that, upon her appointment, she is sufficiently pragmatic to have worked out an arrangement that secures or maintains her financial security, despite the relatively-low public sector pay. Like in Akunyili's case, this may not have necessarily followed the proper public service compensation procedures, if indeed it was the case.

The National Assembly has also played a key role in shaping the destinies of the organisations studied. While they have passed various amendments to strengthen the EFCC Act, the ICPC Amendment Bill has been pending before it for nearly a decade, and ICPC has, to date, refused to actively lobby for its passage. The various uncomplimentary comments made about ICPC in the legislative houses, and their decision to reject one nominee as ICPC Chairman, suggests that the legislature is alive to its responsibilities to ensure that public service organisations deliver on the mandate for which they were set up. NAFDAC similarly enjoyed legislative support to strengthen its powers and enforce its regulations, and FIRS was granted complete autonomy from the Federal Ministry of Finance. The National Assembly also enacted the CEMA 2004 to refocus the NCS on revenue administration, and is currently reviewing the Act to make the NCS more effective. Therefore, the legislature has been a key ingredient in shaping organisational performance. More often than not, this influence is for altruistic reasons. In a few cases, such as appropriating money for equipment that ICPC did not need, rather than appropriating money for the things it needs, that influence may not always be for a positive purpose.

Internal pressure played a part in the reforms of all the well-performing organisations. The pressure from citizens following the humiliation they 
receive at international airports, and the effect of the corruption stigma that Nigeria has on businesses, created an imperative for government to act and create EFCC. There was also widespread revulsion about counterfeit medicines, particularly as many children were dying as a result, and this gave an impetus for the reform of NAFDAC. The internal pressure to improve the tax administration done by FIRS was mounted by government itself.

External pressure, particularly from international partners, is surprisingly potent, given that Nigeria cannot be described as a donor-dependent country by any means. The pressure to create EFCC can be traced directly to the listing of Nigeria as a 'non-cooperating country' by the international community; there was global pressure to fight counterfeit medicines which contributed to prompting the reforms in NAFDAC; and there was advice from various international quarters that Nigeria needed to diversify away from oil, and focus on taxes, if it is to achieve the economic reforms that it planned to achieve.

In conclusion, political and policy considerations play an important role. However, this role is not decisive, as evidenced by the political and policy support for organisations such as ICPC which then did not translate into atypical performance mainly due to ineffective organisational conditions and weak leadership. The notion, therefore, that the underlying political economy in which an organisation is placed ultimately will overcome and shape all the other causal factors and thus determine what performance is possible (Leonard, 2006; Bebbington and McCourt 2007) appears to me to be deterministic - the danger when analysing pockets of effectiveness that Leonard himself later warns against in 2008 (Leonard, 2008). 


\section{Institutional Factors}

Institutions matter and can affect organisational performance (North, 1990; Boyne and Meier, 2009). Many authors propose that weak institutions are likely to breed weak organisations (Lynn, et al., 2000; Rodrik, et al., 2004; Holdt, 2009). The weak institutional conditions in many developing countries is often attributed to various factors, including colonialism, history, culture, patrimony, the 'resource curse', and even geography. However, the very existence of atypical performers in dysfunctional environments suggests that institutions need not be binding constraints and can be overcome. Tendler (1997) makes the point that whole countries are still labelled as good or bad in the literature, and that little effort is made to study discrete aspects of good performance within developing countries. It is clear that even in the most dysfunctional environments, there can be pockets of excellence (Leonard, 2008).

All the organisations in this study operate under the same broad institutional conditions. However, there are nuances and differences. For anticorruption, there is clear political and public appetite for the work of EFCC and ICPC. This is evidenced by the strength of the laws setting up both organisations; the willingness of the legislature to strengthen the laws; the protection afforded the agencies by the judiciary; and the relative autonomy that the organisations enjoy from the executive arm of government. In his inaugural speech on becoming President, President Obasanjo described corruption as "the greatest single bane of our society today" (Obasanjo, 1999). Successive administrations have also resolved to fight corruption. However, the anticorruption fight has had to contend with societal and cultural institutions which can perversely appear to condone corruption. The approaches adopted by EFCC differ from those adopted by ICPC. EFCC has found ways to overcome institutional constraints, while ICPC appears to have allowed itself to be trapped by them.

The public perception of issues can shape institutions and the way that things are done. There is a stark difference between how the populace views 
the issue of fake and counterfeit drugs and how they view the issue of fake and counterfeit consumer goods. While there is strong institutional support to combat the menace of fake drugs, the enthusiasm of the public for combating what they view as the 'victimless crime' of counterfeit goods is nowhere near as strong. Therefore a better institutional environment exists for NAFDAC to function than that that exists for SON. However, through education and awareness-raising, $\mathrm{SON}$ is beginning to highlight the health risks of substandard goods, in the hope that it will gain the support of the public for its work. It is likely to take a while before this public attitude changes. The role of the NCS is an important consideration here. While fake drugs are destroyed immediately they are seized, impounded substandard goods are auctioned off and find their way into the market. Most things on the NCS Import Prohibition List are sold openly in Nigerian markets and even on the streets. They would have had to have entered the country through the borders, for which the NCS is the primary agency responsible. In conclusion, institutions do not only shape societies, but are often themselves shaped by societies.

An activist government has an unparalleled capacity to shape institutions and improve organisational performance (Tendler, 1997). Nobody likes to pay taxes. Collecting taxes is even more difficult where there does not appear to be an obvious social contract between the government and citizens. Both NCS and FIRS face this same institutional constraint, but FIRS has performed well despite it, largely due to its own internal reorganisation and a concerted anticorruption effort. There is a civic education effort but it is not clear that this has been successful in changing the attitudes of citizens to taxation. What appears to have worked instead has been compulsion and enforced compliance, using the executive powers of government.

In conclusion, institutions matter. It is difficult to divorce an organisation from its institutional context. However, there is evidence from my study, and that of others (Esman and Uphoff, 1984; Tendler, 1997, Collins, 2001; Owusu, 2005; Athreye, 2011), that leaders and atypical organisations can 
overcome institutional constraints and even help to shape new institutions. The determinism of the three main strands of institutional theory (rational choice, historical and sociological) is challenged by the very existence of atypical organisations. Institutions can pose constraints to organisational performance (Rodrik, 2005), but these constraints are not always so binding as to be insurmountable.

\section{Clarity of Expectations}

Some authors argue that organisations that have clear expectations are likely to perform better than those without (Grindle, 1997; Leonard, 2008). For the leaders that engineered the reforms of EFCC, NAFDAC and FIRS, the expectations from the president that appointed them were very clear reform the organisation and the function that it performs, reduce corruption, stamp out fake drugs, and increase tax revenue. These expectations are clearly expressed in the enabling laws for each organisation. However, the expectations on ICPC are similarly very clear but this has not had the desired effect on the organisation. The case of ICPC suggests therefore that clarity of expectations, without more, is not enough.

The expectations on SON are not very clear. On the one hand, a narrow interpretation of its enabling law could be that its role is simply to set standards, rather than enforce them. However, as Jinadu points out, the idea that a regulatory agency in the developing world can simply sets standards and not enforce them is not a popular one (Jinadu, 2009). In practice, SON has widened its expected role to include enforcement and the Director-General's 6-Point Agenda is testament to this.

According to its enabling law (CEMA) the expectations on the NCS are clear: collect revenue and protect the borders. The Ministry of Finance has made it clear to NCS that its primary role is revenue generation. However, there appears to be conflicting messages from different arms of government. 
The Ministry of Interior emphasises NCS's border protection duties and the Ministry of Trade and Industry emphasises its key role in trade facilitation across the West African region. The NCS struggles with these various strategic imperatives. It accepts its responsibility to raise revenue, but many within the organisation see revenue-generation as a by-product of what they consider to be its primary function - border protection.

However, A.L. Ikpebe, Comptroller of Customs, Enforcement, NCS, was not of the view that the diversity of roles presents any sort of conflict. In my interview with him on 22 March, 2012, he explains the inter-linkages between the various roles:

- First you need to secure the borders and prevent the illegal entry of arms, ammunition and banned substances, before you can have an environment conducive for economic activity. "If there is no peace, you cannot talk of production, talk less of revenue-generation";

- Unless NCS can raise the revenue that it needs to operate, its ability to effectively secure the borders may be compromised

- NCS has a duty to encourage the growth of local industries by encouraging the production of excisable goods for internal consumption and export. This yields revenue from excise duty; and

- Trade facilitation helps to grow the economy, a key task to which NCS contributes.

He argues therefore that one should not think in terms of one overriding function, but of 4 intertwined and interdependent functions.

Clear expectations are to be preferred over unclear ones. While clarity of expectations appears to be a contributing factor to atypical performance, it is not, in itself, sufficient. There are various organisations the expectations on which are very clear, but that still underperform, largely because other key ingredients, such as effective leadership and strong political and policy support, are not in place. 
To conclude the discussion on external factors, it is clear that external factors are intertwined with the internal factors in the way that they affect the dependent variable - performance. That they affect performance is not in doubt. What has not been clear up to now is how important each factor is relative to another factor, and whether each one is more (or less) important in developing countries than in industrialised ones (Leonard, 2008, p.14). My finding is that while these factors, internal and external, are each necessary for atypical performance (where applied correctly), they are, in themselves, insufficient to produce it. I will argue in the next section that the amalgam that binds the internal and external factors together in such a way that they produce atypical performance is demand.

\subsection{Demand}

The empirical chapters in this dissertation have demonstrated that most of the literature on atypical performance have some merit. However, it is also clear that there are still significant gaps in our knowledge about how atypical performance comes about in dysfunctional environments. Without immersing oneself in the environment and studying the phenomenon from within, it is easy to be oblivious of some key conditions and nuances that are crucial for atypical performance in developing countries. On reviewing the relevant literature, my view was that current insights do not adequately explain what brings about and sustains atypical performance in dysfunctional environments. My original idea, as shown is my conceptual framework at the end of Chapter 2, is that there is a 'black triangle' of demand which occasions atypical performance. That triangle creates an interrelation between government, civil society (including the private sector) and citizens. When that interrelation is strong enough, it affects the internal and external conditions in such a specific way that it creates the conditions for atypical performance to occur.

Throughout the empirical chapters, I have adopted the economic definition of demand as the basis for building my understanding of the phenomenon 
of strong public sector performance in weak governance environments. Sullivan and Sheffrin (2003) define demand as the informed desire for something, backed by the ability and willingness to pay for it. In adapting this definition to atypical performance, we have taken demand to mean the desire to bring about improved performance, backed by the ability (legislation, human and financial resources, and political backing) and willingness (through purposeful leadership, anticorruption and the use of performance management, inter alia) to bring it about.

President Obasanjo, who set up both EFCC and ICPC, is an anticorruption campaigner who was advocating against official corruption before he even came to power. He was a co-founder of Transparency International and the first bill that he sent to the National Assembly was an anticorruption bill which he drafted in his own hand. The institutional environment and the policy and political support for both organisations were, therefore, very similar. However, my conclusion to the case study on anticorruption was that a convergence of national and global factors created a demand for action. This demand, in turn, created the favourable institutional and organisational conditions that enabled EFCC to be successful. I argued that this convergence was absent in the case of ICPC. While managerial differences exist, I argued that the main difference was that EFCC was occasioned by demand and ICPC was not.

In the regulatory quality case study, I concluded that, although the internal and external factors that affect NAFDAC's performance were similar to those to be found in EFCC, there was no evidence of a convergence, at a particular point in time, in the same way as there was for EFCC. Instead, there had been a steady build up of national and international pressure. Citizens expressed their outrage each time a child dies from fake drugs, and neighbouring countries had started to ban pharmaceuticals coming from Nigeria. An important additional dimension is that the president of Nigeria at the time, who is an anticorruption activist, equated the trading in fake drugs to corruption and fought it with the same vigour with which he fought other types of corruption. Lastly, and equally importantly, the Director-General whom the president appointed to reform NAFDAC had lost her own sister to fake drugs. There was for her, therefore, both a professional and personal drive to excel at the job. All of these factors created an imperative for atypical performance that was similar in some 
respects to the imperative for Nigeria to tackle political corruption, money laundering and advance fee fraud that created the environment for EFCC to come into being and thrive.

The case study on revenue administration and the conditions that shaped FIRS's atypical performance also share a number of characteristics with those of EFCC and NAFDAC. The reforms in FIRS were also given impetus by a president who viewed the underreporting of revenue as corruption. $\mathrm{He}$ also blamed the inefficiency of the revenue administration process on corruption. This converged with a need for Nigeria to diversify away from oil, given falling oil prices at the time, and advice (if not pressure) from the international community to do so. President Obasanjo headhunted the type of leader that he wanted and provided the required legislation, protection and backing for her to succeed. These converged with a deep, deliberate and systematic internal strengthening process, a strong focus on tackling internal corruption and a rigorous and effective performance management and reward system. Although NCS was covered by the same ambition to raise revenue as FIRS was, it is not evident that the government placed the same sort of emphasis on its improvement. The convergence of external and internal factors that occurred in FIRS has, therefore, not occurred in NCS. However, NCS is now beginning to adopt some of the management practices that FIRS has used to such great effect.

In summary, my suspicion that something is lacking in the literature appears to have been borne out. The proposition that demand is the amalgam that binds the internal and external factors together in such a way as to enable atypical performance appears to hold. While all the factors identified in the literature play important roles, those roles are not decisive by themselves. From my empirical work, what appears to be decisive is the presence or absence of demand. In each atypical performer that I studied, there was an informed desire to bring about improved performance, backed by an ability to bring about that performance and a desire to deploy that ability.

In the next chapter, I will continue to explore the concept of demand, including its meaning, make-up, nature and distinguishing characteristics. This theoretical exposition will provide further context to my empirical findings. 


\subsection{Cross-case Comparison}

For ease of reference, I will now show, in tabular form, the similarities and differences between the 3 atypical organisations. The table shows some remarkable similarities on each of the explanatory variables considered in this study, but also some significant differences. The differences are perhaps more marked in FIRS than in the other two.

\begin{tabular}{|c|c|c|c|}
\hline $\begin{array}{l}\text { Explanatory } \\
\text { Variable }\end{array}$ & EFCC & NAFDAC & FIRS \\
\hline Leadership & 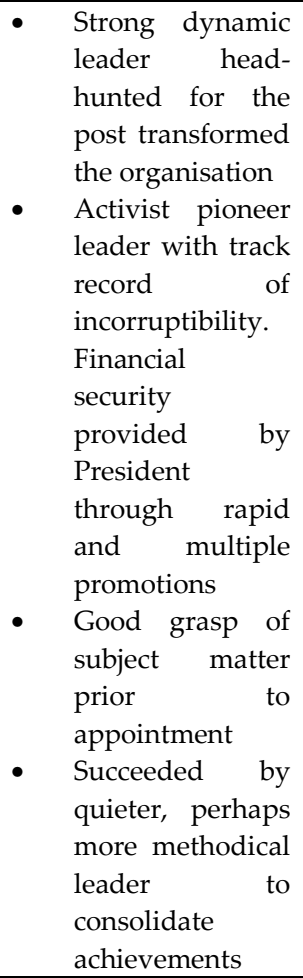 & 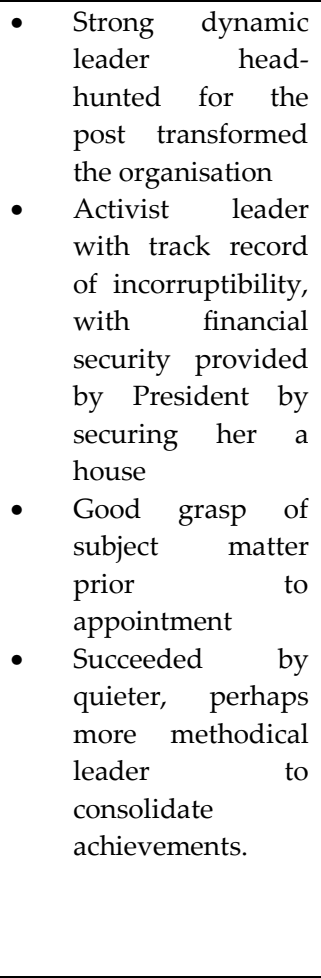 & $\begin{array}{l}\text { - Strong dynamic } \\
\text { leader head-hunted } \\
\text { for the post } \\
\text { transformed the } \\
\text { organisation } \\
\text { Respected } \\
\text { professional } \\
\text { selected as leader, } \\
\text { with financial } \\
\text { security probably } \\
\text { provided } \\
\text { President by } \\
\text { Good grasp of } \\
\text { subject matter prior } \\
\text { to appointment } \\
\text { Still in post as at } \\
\text { March 2012. The } \\
\text { only one of the } 3 \\
\text { leaders to complete } \\
2 \text { full terms of } \\
\text { office. }\end{array}$ \\
\hline Funding & $\begin{array}{ll}- & \text { Received } \\
\text { considerably } \\
\text { more funding } \\
\text { than ICPC and is } \\
\text { more effective at } \\
\text { mobilizing funds } \\
\text { Receives } \\
\text { significant donor } \\
\text { support }\end{array}$ & $\begin{array}{l}\text { Receives about } \\
30 \% \text { more funds } \\
\text { than SON, } \\
\text { although } \\
\text { government } \\
\text { funding per capita } \\
\text { is the same } \\
\text { - Generates double } \\
\text { SON's rate of }\end{array}$ & $\begin{array}{l}\text { Was able to } \\
\text { negotiate to keep } \\
4 \% \text { of all non-oil } \\
\text { revenue. This } \\
\text { means that FIRS } \\
\text { has the funds to } \\
\text { operate effectively. } \\
\text { Generates more } \\
\text { than 3-times what }\end{array}$ \\
\hline
\end{tabular}




\begin{tabular}{|c|c|c|c|}
\hline & & $\begin{array}{l}\text { internally } \\
\text { generated revenue } \\
\text { Receives } \\
\text { significant donor } \\
\text { support }\end{array}$ & $\begin{array}{l}\text { NCS generates } \\
\text { Receives significant } \\
\text { donor support }\end{array}$ \\
\hline $\begin{array}{l}\text { Recruitment } \\
\text { Process }\end{array}$ & $\begin{array}{l}\text { - Open and } \\
\text { transparent } \\
\text { recruitment } \\
\text { process through } \\
\text { wide } \\
\text { advertisement, } \\
\text { with aptitude } \\
\text { tests and } \\
\text { interviews but } \\
\text { EFCC does not } \\
\text { put its name on } \\
\text { the } \\
\text { advertisements }\end{array}$ & $\begin{array}{l}\text { - Open and } \\
\text { transparent } \\
\text { recruitment } \\
\text { process, through } \\
\text { wide } \\
\text { advertisements, } \\
\text { with aptitude tests } \\
\text { and independent } \\
\text { panel interviews. }\end{array}$ & $\begin{array}{l}\text { Open and transparent } \\
\text { recruitment process, } \\
\text { through } \\
\begin{array}{l}\text { advertisements, wide } \\
\text { aptitude tests } \\
\text { independent and } \\
\text { interviews. }\end{array}\end{array}$ \\
\hline $\begin{array}{l}\text { Performance } \\
\text { Management }\end{array}$ & $\begin{array}{l}\text { Strong internal } \\
\text { performance } \\
\text { management } \\
\text { system that } \\
\text { rewards good } \\
\text { performance and } \\
\text { sanctions poor } \\
\text { performance. } \\
\text { Whistle-blowing }\end{array}$ & 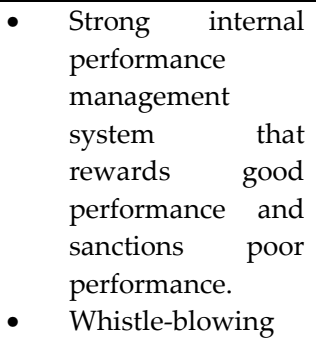 & 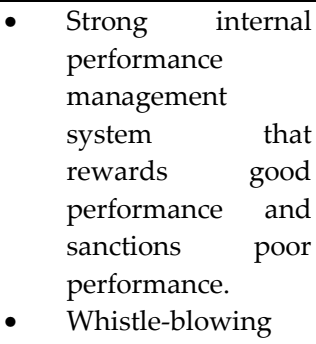 \\
\hline $\begin{array}{l}\text { Pay and } \\
\text { Conditions of } \\
\text { Service }\end{array}$ & $\begin{array}{ll}\text { - Not a factor in } \\
\text { performance } & \text { as } \\
\text { terms } & \text { are } \\
\text { identical } & \text { for } \\
\text { comparator } & \\
\text { organisation } & \end{array}$ & $\begin{array}{l}\text { - Not a factor in } \\
\text { performance as } \\
\text { terms are identical } \\
\text { for comparator } \\
\text { organisation }\end{array}$ & 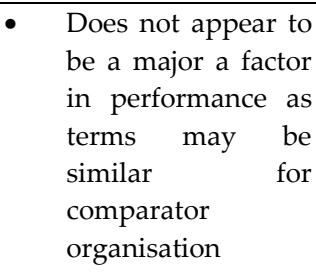 \\
\hline $\begin{array}{l}\text { Use of } \\
\text { Technology }\end{array}$ & $\begin{array}{lr}\text { - Very } & \text { strong } \\
\text { technology focus } \\
\text { both for general } \\
\text { information } \\
\text { technology uses } \\
\text { and } \\
\text { deploying } \\
\text { technology } \\
\text { enhance } \\
\text { functions. }\end{array}$ & $\begin{array}{lr}\text { Very } & \text { strong } \\
\text { technology focus } \\
\text { both for general } \\
\text { information } \\
\text { technology uses } \\
\text { and for deploying } \\
\text { technology to } \\
\text { enhance } \\
\text { functions. core }\end{array}$ & 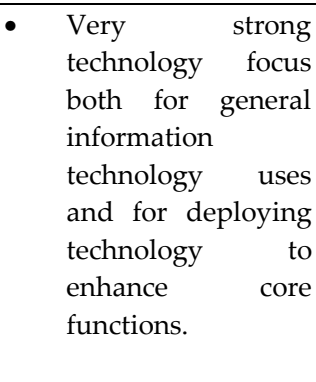 \\
\hline
\end{tabular}




\begin{tabular}{|c|c|c|c|}
\hline $\begin{array}{l}\text { Publicity, } \\
\text { Image and } \\
\text { Media } \\
\text { Relations }\end{array}$ & $\begin{array}{l}\text { Very strong use } \\
\text { of, and support } \\
\text { from, the media. } \\
\text { Learnt from } \\
\text { NAFDAC's } \\
\text { success in this } \\
\text { regard }\end{array}$ & $\begin{array}{l}\text { Very strong use of, } \\
\text { and support from, } \\
\text { the media. } \\
\text { "Stampeded by } \\
\text { the media" to } \\
\text { move quickly to } \\
\text { address problems. }\end{array}$ & $\begin{array}{l}\text { - } \\
\text { medrong use of the } \\
\text { melling a difficult } \\
\text { message: pay taxes } \\
\text { although the } \\
\text { government may } \\
\text { not be doing its bit. }\end{array}$ \\
\hline $\begin{array}{l}\text { Strong } \\
\text { Political } \\
\text { Support }\end{array}$ & $\begin{array}{l}\text { - } \begin{array}{l}\text { President was an } \\
\text { anti-corruption } \\
\text { crusader }\end{array} \\
\text { Agency given all } \\
\text { the legislation it } \\
\text { needs to function } \\
\text { President } \\
\text { provided full } \\
\text { support for } \\
\text { actions and did } \\
\text { not undermine } \\
\text { organisational } \\
\text { leadership }\end{array}$ & 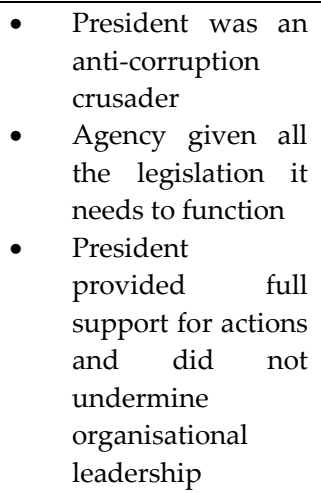 & 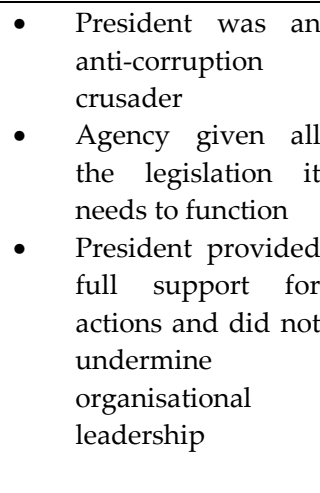 \\
\hline $\begin{array}{l}\text { Favourable } \\
\text { Institutional } \\
\text { Factors }\end{array}$ & 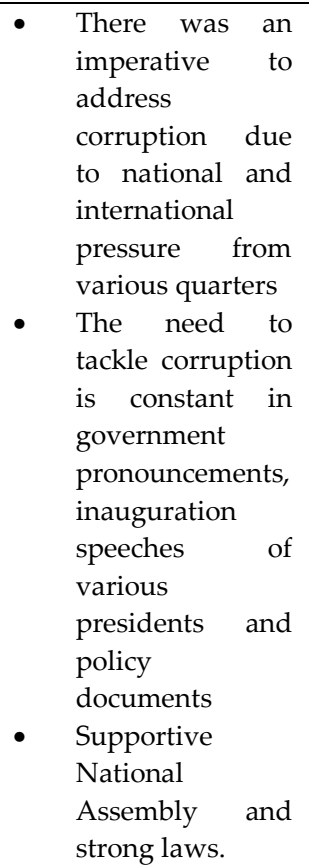 & $\begin{array}{l}\text { - Although there is } \\
\text { public outrage } \\
\text { when children die } \\
\text { from fake drugs, it } \\
\text { does not appear } \\
\text { that the pressure } \\
\text { to clean up } \\
\text { NAFDAC was any } \\
\text { stronger than that } \\
\text { to strengthen } \\
\text { SON. The personal } \\
\text { preferences of the } \\
\text { President at the } \\
\text { time seemed to be } \\
\text { the main catalyst. } \\
\text { Supportive } \\
\text { National } \\
\text { Assembly and } \\
\text { strong laws }\end{array}$ & 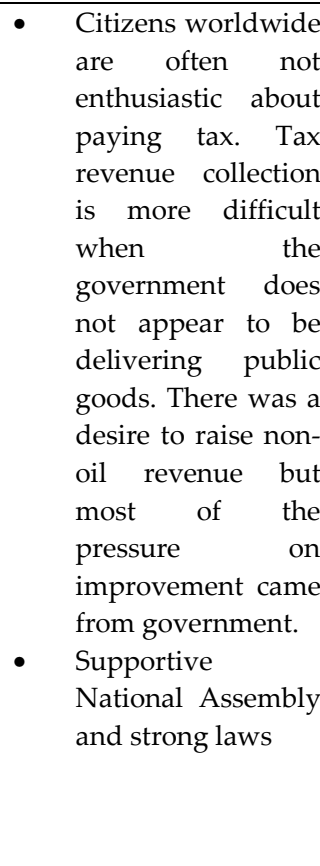 \\
\hline
\end{tabular}




\begin{tabular}{|c|c|c|c|}
\hline $\begin{array}{l}\text { Clarity of } \\
\text { Expectations }\end{array}$ & $\begin{array}{l}\text { - Expectations of } \\
\text { EFCC were very } \\
\text { clear - get } \\
\text { Nigeria off the } \\
\text { FATF's List of } \\
\text { Non- } \\
\text { Cooperating } \\
\text { Countries and } \\
\text { improve the } \\
\text { nation's image } \\
\text { internationally. }\end{array}$ & $\begin{array}{l}\text { President's } \\
\text { expectation was } \\
\text { simple but clear - } \\
\text { "I want you to go } \\
\text { and clean up } \\
\text { NAFDAC. Tell me } \\
\text { what you need to } \\
\text { do the job". }\end{array}$ & $\begin{array}{l}\text { - The expectations on } \\
\text { FIRS are clear: } \\
\text { Raise non-oil } \\
\text { revenue and } \\
\text { improve the } \\
\text { administration of } \\
\text { taxes in Nigeria. }\end{array}$ \\
\hline
\end{tabular}

Table 14: Cross-case Comparison of Atypical Performers

\subsection{Conclusion}

This chapter is a cross-case analysis of the key empirical findings of this dissertation. It shows that very similar factors affect the performance of all 3 atypical performers, many of which are absent in the underperforming organisations.

This chapter also analyses some of the assumptions underlying this study. First, it looked at the focus on outputs in determining performance, and found that in some cases, the delivery of outputs can, on its own, be insufficient. It also considers that various internal and external factors are necessary but, in themselves, insufficient to bring about atypical performance in dysfunctional environments. Having looked at confirming and disconfirming literature on the subject, I argue that the amalgam that binds the key conditions together in such a way that they engender atypical performance is demand, and that without demand, atypical performance is unlikely to occur. Even where it is to occur against the odds, it is unlikely to be sustained.

In the next chapter, I will explore the concept of demand more fully from a theoretical standpoint and propose a new theory which consolidates what I have learnt from the empirical work. 


\section{Chapter 8 Towards a New Theory for Overcoming Institutional Constraints}

Episodes in the history of science abound where a plethora of fact worked against the discovery of theory (Rosen, 2007, p. 487)

This chapter consolidates my knowledge of how and why certain public sector organisations are able to achieve atypical performance despite operating in dysfunctional environments. A brief synthesis of the factors that supported atypical performance in the case studies, drawn from Chapter 7, is first undertaken. I then discuss the possibility and viability of building theory from case study research. Throughout this dissertation, I have explored the concept of demand. In this chapter, I will undertake a theoretical exposition of the concept, and offer it as a means through which organisations can overcome institutional constraints to achieve atypical performance.

\subsection{Brief Summary of Empirical Findings}

In Chapter 7, I revisited my dependent variable (performance) as it applied to each case study and organisation studied. I then undertook a synthesis of the internal and external factors affecting performance, which I used as my explanatory variables.

In the first case study (anticorruption), I found that a convergence of national and global imperatives, at a particular point in time, created the favourable institutional and effective organisational conditions that facilitated atypical performance in one organisation. The government perceived a need for Nigeria to get off the list of non-cooperating countries in the global effort to fight money laundering and financial fraud. Being on this list was harming businesses and embarrassing citizens, and would jeopardise the chances of the country to secure the debt relief that it sought at the time. The government felt that the existing anticorruption agency, 
ICPC, was not equipped to address these new challenges, and created a new organisation. Let us tentatively describe this convergence of imperatives and conditions as demand.

In the second case study (regulatory quality), I found that favourable institutional and effective organisational conditions facilitated atypical performance in one organisation. These conditions were not apparent in the comparator organisation. However, there was no evidence of the sort of convergence of global and national imperatives (at a particular point in time) that was the case in the case study on anticorruption. Instead, an interesting dimension that emerged was the role of an activist political leader, coupled with that of an activist organisational leader, and their effect on creating favourable institutional and organisational conditions. In addition to these, there was strong pressure from the media and businesses had started to suffer. This was another sort of convergence that we can also tentatively describe as demand.

In the third case study (revenue administration), there was similarly a convergence of favourable institutional conditions and effective organisational conditions that was stronger in one organisation than in the comparator organisation. The imperative seems to have simply been the need to raise additional revenue by diversifying the economy away from oil and tackling the corruption that was diminishing the government's true revenue generation potential. Again, here, an activist president, an anticorruption campaigner, sought out a suitable organisational leader and provided the enabling institutional environment for effective organisational conditions to be created. What can also tentatively be described as demand, however, was unidirectional in this case. It was driven almost entirely by the government, since citizens are usually generally unenthusiastic about paying taxes, and that enthusiasm is even less when the government has a weak track record of delivering public goods with the taxes it collects.

Our next task is to assess the extent to which these empirical findings can be generalised to theory. 


\subsection{Building Theory from Case Study Research}

This study has been designed from inception to enable the building of theory from multiple case studies, following the 'Process of Building Theory from Case Study Research' set out by Kathleen Eisenhardt (1989, p.533). This involved:

- Defining a research question, and some initial propositions, rather than a hypothesis;

- Specifying the cases to be studied and selecting them through theoretical, rather than random, sampling;

- Using multiple data collection methods;

- Flexible and opportunistic data collection methods (for instance, I conducted an interview on a flight between Abuja, Nigeria and London, England);

- Simultaneously collecting and analysing data, including keeping a Theoretical Sensitivity Diary (Strauss and Corbin, 1990);

- Analysing within-case findings and cross-case patterns;

- Tabulating evidence for each dimension or construct and looking for commonalities and reasons for them; and

- Comparing with literature (confirming or disconfirming).

Eisenhardt lists the strengths of using this approach as:

1. Its likelihood of generating novel theory, with less researcher bias than theory built from incremental studies or arm-chair, axiomatic deduction;

2. An emergent theory that is likely to be testable and hypotheses that can be proven false; and

3. A resultant theory that is likely to be empirically valid, because it is so intimately tied to evidence and lived experience.

She also lists the dangers to avoid in using this approach and advocates against developing overly complex theory, theory that tries to capture everything, and theory that is narrow and idiosyncratic. I will do my best to avoid these pitfalls. 


\subsection{The Concept of Demand}

Throughout this study, I have used the word 'demand' in a variety of contexts. I started with an economic definition of demand, to mean the desire for something, backed by the ability and willingness to pay for it or bring it about (Sullivan and Sheffrin, 2003). In Chapter 2, I distinguished my use of the term 'demand' from concepts of social accountability, often called demand-side accountability. Demand-side accountability focuses on enhancing government accountability and transparency and strengthening the channels through which citizens can hold government to account (McNeil and Mumvuma, 2006; McNeil and Malena, 2010). In many developing countries, these mechanisms (open budget indexes, freedom of information acts, etc) often lack the real power to make the government to behave differently and are frequently ignored.

Advocates of social accountability mechanism often argue that it is possible to somehow create a 'coalition for change' and that that will bring about institutional change. Many donors have been seduced by this proposition and have provided funding to various non-governmental organisations for the purpose of mobilising the said coalition. However, collective action that can lead to transformative change does not arise automatically from strengthening civil society organisations (Institute of Development Studies, 2010). Without engaging with the source of power (usually the state), collective action often has limited effect, particularly in developing countries. "Effective collective action involves organising around broadly shared goals, not just narrow, exclusive interests; and ongoing action that engages with the state, not just ad hoc protests or self-help initiatives" (Institute of Development Studies, 2010, p.36).

In this study, I have applied the term 'demand' to concepts of pressure, needs, interests, desires, imperatives, convergences, individual and collective will, and inevitability. The Indicators for Testing the Existence of Demand that I set out at the end of Chapter 2 demonstrate that these concepts can arise from various sources: government, private sector, donors operating in country, international and multilateral organisations, the media, professional associations and pressure groups, service users, and citizens. 
The concepts listed above (including pressures, needs, interests and desires) can remain latent and are often always there. There is, for instance, almost always a pressure, need, interest and desire for public sector organisations to perform well; for corruption to be reduced; for taxes to be collected; and for businesses to be better regulated. While they are latent, they remain what they are: pressures, needs, interests and desires. The government, the elite, and the organisations at which they are directed can often safely ignore them, and will sometimes dismiss them as 'the anti-people conspiracy of the monopoly capitalists' (Bardhan, 1984, p.77), or with similar invectives such as the work of detractors, fifth columnists and members of the opposition trying to bring down the government because they have lost power'. Therefore, while these concepts are latent, they do not qualify to be termed 'demand'.

Relevant concepts will only become demand when they are backed by the power to force through the change required, and the holder of that power demonstrates a willingness to deploy it. This combination is crucial. It is, of course, possible to have the power to act on pressures and desires, without the willingness to deploy that power. This unwillingness can arise for many reasons, including political calculations, the need for political survival, intra-elite pressure, the need to avoid precipitating a crisis in the country, corruption, personal or pecuniary interest, stronger pressure for the maintenance of the status quo, or lack of reform-mindedness. Conversely, it is also possible to possess a willingness to deploy power but not to have any pressure, need or opportunity to do so. Machiavelli argues:

Thus, for the Israelites to be ready to follow Moses, in order to escape from servitude, it was necessary for him to find them, in Egypt, enslaved and oppressed by the Egyptians [...] Theseus could not have demonstrated his prowess had he not found the Athenians dispersed. The opportunity given them enabled these men to succeed, and their own exceptional prowess enabled them to seize their opportunities; in consequence their countries were ennobled and enjoyed great prosperity. (Machiavelli, 1999, p.20) 
Therefore, for there to be demand, the three ingredients must be present: some sort of pressure, the power to respond to that pressure, and the willingness (or passion) to deploy that power. In each of the case studies in my empirical chapters, this convergence of demand exists.

In the EFCC case study, there was a clear imperative for Nigeria to get off the Financial Action Task Force's List of Non-cooperating Countries for money laundering. An 'activist' government deployed its power to create appropriate legislation, seek out a suitable leader and provide the enabling environment for atypical performance to thrive. There was a clear willingness to deploy that power, going by the fact that the government amended the initial qualification for EFCC Chairman to accommodate the right candidate and the legislature effected several amendments to the EFCC law to ensure that it is able to be effective.

In the NAFDAC case study, the pressure to tackle fake and substandard drugs was palpable, particular where young children had died as a result of ingesting fake drugs. Similarly, the government deployed its power to strengthen the extant legislation, seek out the right leader and provide the enabling environment (including financial resources) for NAFDAC to achieve atypical performance.

In the FIRS case study, the pressure to diversify the economy away from oil revenue was evident. The government deployed its power to grant FIRS autonomy from the Federal Ministry of Finance, sought a suitable leader and provided the enabling environment (including financial resources) for atypical performance to occur.

These issues, in addition to favourable institutional and organisational conditions made atypical performance more likely. What is clear is that there are several mechanisms at work. This makes it dangerous to think in terms of sufficient conditions. It is important, instead, to think in terms of combinations of factors (Booth, 2010) and how they interact to create atypical performance. To gain this understanding, it has been necessary to root our knowledge in lived experiences. It is clear that factors such as leadership, management and technical capacity matter, as do political and policy conditions and institutions. What we have been searching for is the amalgam that binds these together in such a way that they are able to 
catalyse atypical performance in dysfunctional environments. My argument is that this amalgam is demand.

I will now explore these concepts of pressure, power and passion in greater theoretical detail.

\subsubsection{Pressure}

The Collins Paperback English Dictionary (1991, p.669) defines pressure as 'the exertion of force by one body on the surface of another'; 'a moral force that compels'; and 'to constrain or compel, as by moral force'. I will use the term 'pressure' to encompass the concepts of desires, interests and moral force or persuasion. Bentley (1949, p.258) argues that pressure is always a group phenomenon, which indicates the push and resistance between groups in a society. The argument that pressure is a group phenomenon excludes, erroneously in my view, the ability of the individual to exert pressure. If a group desires something or has a particular interest to exert certain pressure, it is because the individuals in that group share those desires and interests (Olson, 1971, 126).

However, where pressure is applied, it can often be resisted. The recipient of the pressure could react in a number of ways. They could:

- Simply absorb the pressure, comfortably accommodate it and do nothing;

- Refuse to yield to the pressure, despite any attendant discomfort that it brings;

- Actively resist the pressure by pushing back and exerting counter pressure of equal force;

- Overwhelm the original pressure by mounting pressure that is stronger than that originally received; or

- Yield to that pressure.

There is, therefore, a constant push and pull between what is desired and what is allowed to happen. In his book Discourses on Livy, Machiavelli states that "[...] nature has so created men that they can desire everything but are unable to obtain everything, so that their desire is always greater 
than their power of acquisition" (Machiavelli, 1997, p.99). Therefore, it is possible, and indeed likely, to desire a certain course of action or have an interest in a certain outcome. However, the power to affect that course of action or acquire that desired outcome cannot always be guaranteed or even presumed.

Consequently, over a long period of time, there can be pressure on public sector organisations to perform well. For as long as that pressure can be accommodated or repelled, that pressure remains desires, interests and moral persuasion. It lends itself more to social accountability efforts and does not rise to the threshold of demand.

As already set out in Chapter 2, sources of pressure include government, media, donors in country, multilateral organisations, pressure groups and professional associations, civil society organisations and citizens. In the EFCC study, there was pressure from government, citizens, the media, civil society organisations, the private sector and the international community. Government urgently wanted to stop being labelled a non-cooperating country of purposes of money laundering; citizens were fed up with being harassed at airports in other countries once travellers were in possession of Nigerian passports; the media and civil society organisations decried the rate of corruption in the country and wanted government to act; the private sector decried the high cost of doing business as a result of the corrupt environment and the international community (including Transparency International and donors) placed pressure on government to tackle corruption.

In the NADFAC case study, there was pressure from citizens to tackle the prevalence of fake drugs in the country. This pressure became particularly strong following the spate of fatalities of children ingesting fake and counterfeit drugs. Manufacturers of genuine drugs also pressured government to tackle the menace of fake drugs as the importation of genuine drugs manufactured in Nigeria were banned by neighbouring countries.

The pressure on FIRS to improve came primarily from government's desire to grow non-oil revenue in order to deliver an ambitious development programme called the National Economic Empowerment and Development 
Strategy. Government made it clear that it wanted Nigeria to be one of the 20 largest economies in the world by the year 2020, and realised that it was unlikely to achieve it by relying on oil revenues alone.

However, it is unclear at what threshold certain pressure will trigger action. The approach I have taken is necessarily explanatory, rather than predictive.

\subsubsection{Power}

Power generally refers to the ability, capacity, or potential to get others to do something, to command, to influence, to determine or control the behaviours, intentions, decisions or actions of others in the pursuit of one's own goals or interests despite resistance, as well as to induce changes (Belaya and Hanf, 2009).

Power can be examined from a variety of perspectives, including the ability to mobilise bias, produce a result, or order behaviour (Dahl, 1959 and 1961; Foucault, 1990 and 1995; Newswander, 2011). Foucault is of the view that power produces practices, rationalities, and forms of control that can lead to certain outcomes. Power determines what is viable and what is not, and establishes what is normal and abnormal. This ability to influence conception of what is normal and abnormal suggests that power can change long-standing institutions.

In Leviathan, Thomas Hobbes defines power as the "present means to obtain some future apparent good". I have highlighted the two words 'present' and 'means'. 'Present' connotes immediacy and has an instantaneous quality. 'Means' is the capacity or resources to bring something about. A present means therefore is the immediate and instantaneous capacity to bring something about or order future conduct. Hobbes makes it clear that the greatest of all powers is that which is concentrated in a leader within a democracy:

The greatest of human powers, is that which is compounded of the powers of most men, united by consent, in one person, natural or civil, that has the 
use of all their powers depending on his will [...] (Hobbs, 2008, p. 58).

However, apart from power obtained by democratic consensus, the ability to control an environment and condition the behaviour of others can from other sources. Gene Sharpe (2010, p.18) lists the sources of political power as including:

- Authority - the belief among the people that the regime is legitimate and should be obeyed;

- Human Resources - sufficiently high and important persons and groups obeying rulers;

- Skills and Knowledge - the ability of the regime to harness the skills and knowledge of cooperating persons and groups;

- Intangible Factors - such as the control of ideology, religion and information and using these to induce obedience;

- Material Resources - control over, and access to, natural resources, property, financial resources, the economic system and means of communication and transportation; and

- Sanctions - punishments threatened or applied against disobedience, including the control of the ultimate means of legitimate physical violence.

Again, I have emphasised Hobbes' words, 'depending on his will', to show that the person in whom that power is concentrated does not always deploy it in response to rational choice or other institutional imperative. It is deployed according to his will, and could, therefore, be deployed in an unpredictable way or in a way that may not be apparently logical, rational, sequential or consistent. Of course, in a democracy, such as Nigeria, there are checks and balances that guard against the abuse of that power and diminish the arbitrariness with which it can be used.

Nigeria runs a presidential system of government that is constituted by an executive, a legislature and a judiciary. Apart from the executive, the legislature is therefore a key source of power. Indeed, the legislature can enhance or constrain executive action, as it has done with the legislations governing the various organisations that I studied. While it enhanced executive action in passing the laws and regulations needed for EFCC, 
NAFDAC and FIRS to function effectively, it has not been as supportive of the amendments to legislation that would make ICPC more effective. ICPC needs, for instance, to amend its laws to be able to commence investigations without necessarily waiting for a written petition. On the other hand, the legislature has exercised its power to reject the nominee for the chairmanship of ICPC on the basis that they did not feel that he had the desired energy and passion. It is also the legislature that makes the laws that everyone has to obey and that the judiciary has to enforce.

The judiciary can also enhance or constrain executive power. The power to stop both the executive and legislature from taking certain actions is an important one that can affect organisational performance. The courts have, for instance, outlawed the legislative attempt to repeal the ICPC Act. It has also respected EFCC's practice of plea-bargaining, although express provision is not made for the practice under Nigerian law.

However, in directing the course of organisations, power can compel a certain course of action (positive or negative), and provide protection for that course of action that it compels (Belaya and Hanf, 2009). Nevertheless, it is possible to have power, but lack the willingness to deploy it. The government has the power to reposition ICPC but appears unwilling to deploy it. It similarly has the power to create the enabling environment for SON to thrive but it is not apparent that it is interested in doing so.

The willingness to deploy power is a key ingredient in creating the conditions under which atypical performance can thrive. I have already pointed out that the willingness to deploy that power is not always rational, logical or predictable. Therefore, the next subsection will deal with the willingness to deploy that power, and the conditions that may or may not influence that decision.

\subsubsection{Passion}

Of course, it is unusual for power to be deployed in a completely arbitrary manner devoid of stimuli, incentive, influence or pressure (Besley, 2006, p.41), except perhaps in some cases of mania. Hobbes describes the two types of motions that are peculiar to animals (including humans). The first 
is what he calls 'vital' motions, such as the pulse, the flow of blood through the body or the process of breathing, which must, of necessity, happen. The other, he refers to as 'voluntary' (such as walking or speaking) which is often undertaken as a matter of choice, rather than purely of necessity.

Of appetites and aversions, some are born with men [...] The rest, which are appetites of particular things, proceed from experience, and trial of their effects upon themselves, or other men (Hobbes, 2008, p. 34).

Therefore, a leader who was an anticorruption campaigner before he came into office may choose to focus on those organisations that will perpetuate his anticorruption ideals and not on other organisations (Vallerand, et al., 2007).

Nokkala (2010) builds on the ideas of Schmauss and Justi to argue that natural law is not based on reason but on human instinct and passions. Thomas Besley explains that it is not clear why some individuals take their fiduciary roles seriously while others do not. He attributes it to an intrinsic motivation and explains that actions can be pursued 'for their own sake', rather than because of some well-defined external reward. "Thus, a politician who upholds his duty of loyalty may be willing to do so even though he is forgoing an increase in his utility by doing so" (Besley, 2006, p.40). This is important to note when considering why a politician may deploy power positively in one agency but not in another.

John Stuart Mills sets out the conflicting arguments around the liberty of will and the involuntariness of necessity. On the one hand, the 'Doctrine of Necessity' asserts that human volitions and actions are necessary, inevitable and predictable. This is similar to institutional and rational choice theories in economics. On the other hand, a contrary opinion is that human will is not determined, like other phenomena, by antecedents, but determines itself independently, i.e., that there are no causes which our actions will uniformly and implicitly obey (Mills, 1987, p.22). As Mark Bevir points out, people can wilfully choose to disobey a norm or rule but it is often not possible to divorce belief and desires from actions (Bevir and Rhodes, 2001). Mills also feels that the two concepts are not necessarily inconsistent. You 
can predict action through knowledge of character and antecedents; however, you cannot, thereby, rule out free will and believe that causation is invariable, certain and will follow an unconditional sequence. David Hume supports this point and says that our past experience is not always uniform. Sometimes one action follows from a cause; at other times, the same cause produces a different action (Rosen, 2000, p.439).

Machiavelli's views are in consonance with that of Mills. He postulates that fortune is the arbiter of half the things we do, leaving the other half to be controlled by ourselves (Machiavelli, 1999, p.79). He compares fortune to a violent river: "She shows her potency where there is no well-regulated power to resist her, and her impetus is felt where she knows that there are no embankments and dykes built to restrain her". I would similarly compare institutions to fortune or violent rivers. They are only overwhelming when there is no countervailing power to resist them (Locke, 1988; Berlin, 1995).

Passion can directly impact on performance (Phillipe, et al., 2009). Where there is passion to produce a certain outcome, it is more likely that that outcome would be achieved than if that passion is lacking (Vallerand, et al., 2007).

However, it is possible to have passions and appetites, but, without the power to acquire a particular outcome, those passions and appetites remain unsatisfied. From the empirical studies on NCS and SON, it is clear that the government of Nigeria would like more secure borders, for Nigeria not to be a dumping ground for fake and substandard goods, and to protect local industry by enforcing an import prohibition list. However, these passions and appetites remain, as the government has, so far, been unable to stem the influx of fake and substandard goods. The rising state of insecurity in the country also suggests that it has limited ability to control the illegal importation of arms and ammunitions.

Despite the issues highlighted above, questions remain. Why does the government appear able to stem the influx of fake drugs but not of fake goods? Why does it appear to be disinterested in reforming ICPC? Why does it appear to have been lukewarm about tackling the widely-held perception that NCS is corrupt? Why does it produce an import prohibition 
list but does little to enforce its use? These apparent contradictions make the development of robust theory difficult. However, basing the theory on lived experience about past behaviour helps to explain current behaviour, even if it is difficult to predict future behaviour. I will therefore attempt the construction on theory on that basis.

\subsection{The Theory of Convergent Demand}

The convergence of the 3 elements of pressure, power and passion, as it affects a particular organisation, is what I mean by demand. Where the three elements converge, there is demand. When any one of the three elements is missing, there is no demand. Figure 8 below depicts the interrelationship graphically.

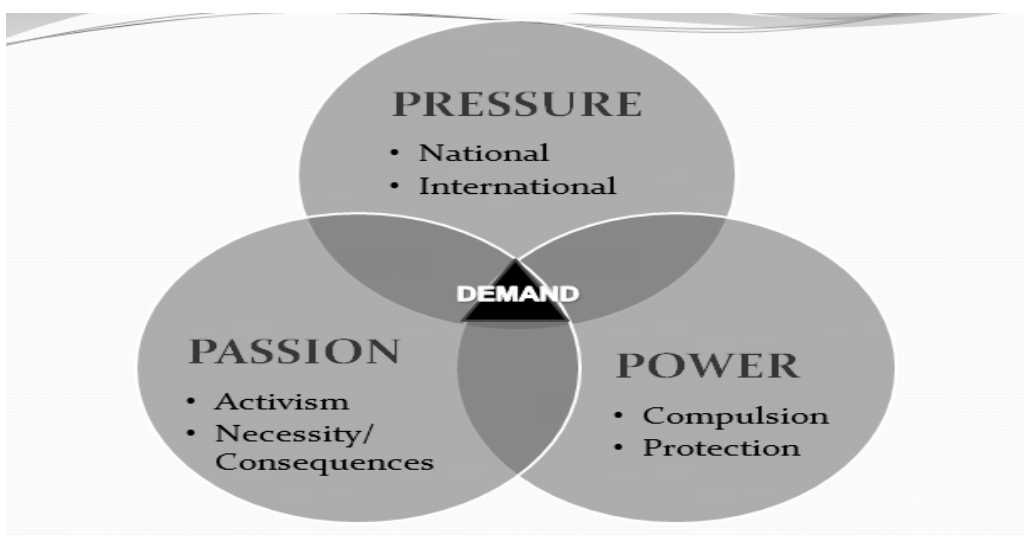

Figure 9: The Concept of Demand

The complementary nature of these concepts is important to bear in mind. There can only be said to be demand on organisations where there is pressure on that organisation or function, and there is power to actualise that pressure, and a passion or willingness to positively deploy that power in response to the pressure. 
I would now like to propose a new theory, based on the analysis above and the results of my empirical studies. I will call it the 'Theory of Convergent Demand' to distinguish it from the more-widely-known understanding of the term 'demand' as used in economics. I propose that:

\section{Public sector organizations in dysfunctional environments are more likely to overcome institutional constraints and perform well when there is convergent demand (i.e., a convergence of pressure, power and passion) in their mandate area.}

When this convergent demand exists, it is more likely to create the favourable institutional conditions and promote the effective organisational conditions necessary for atypical performance to occur. In my empirical work, I have shown that this convergence occurred in every case of atypical performance, even if in different ways, but did not occur in the comparator organisations. In the cases of ICPC, SON and NCS, at least one of the key ingredients was missing in each case. In ICPC, the pressure and power appears to exist but what is lacking is the passion to do something about it. In SON, the power exists but the pressure and passion to do something about it seems to be lacking. In NCS, the pressure and passion appears to be present but the government appears to lack the power to obtain the results that it desires.

From my empirical work, where there appears to be a convergence of pressure, power and passion, it has been possible to overcome institutional constraints. This is consistent with the findings of other authors who have studied the phenomenon of atypical organisations in weak institutional environments. Suma Athreye (2011) explains how the software industry in India overcame highly-unfavourable institutional constraints by capitalising on demand to transform institutions and reform the business environment. The emerging global information technology business created a huge demand for trained engineers and technicians. The private sector in India saw this economic opportunity by occupying the product market spaces 
and business models that avoided the penalties of their weak institutional environment. The demonstration effect of successful business outsourcing offered to multinational corporations created the conditions that forced a positive change in the institutions governing the information technology business as a whole in India (Athreye, 2011). There was global pressure for qualified engineers and technicians, and the power of the Indian software industry to respond to that pressure, and the passion to do it despite daunting institutional challenges.

Similarly, it was through such a convergence that Nigeria was able to able to achieve the atypical performance of nearly eradicating polio in just one year. Between 2009 and 2010, the incidence of polio fell by 99\% from 333 confirmed cases to just 3 confirmed cases. This achievement was made possible through a convergence of efforts between religious, traditional and community leaders and the donor community. Crucially, the effort was driven and supported by the power, clout and passion of the three tiers of government in Nigeria - local, state and federal..$^{50}$

A valid question to ask would be: What is the threshold or tipping point at which these individual components (pressure, power and passion) translate to demand? What are the necessary and sufficient conditions? In trying to answer these questions, I explored the work of Charles Ragin on Comparative Qualitative Analysis (Ragin, 1987; 2000; 2008) to see whether it was possible to set quantitative values for these concepts in order to aid the predictability of their convergence. It very quickly became apparent to me that it would be difficult, if not impossible, to ascribe mathematical values (even of a binary nature) to passions, desires and the human will.

What is clear from my empirical studies is that single factors, even where necessary, are insufficient to explain why certain things happen in certain

${ }^{50}$ Bill Gates, 2011, roundtable discussion with me and others, 26 September, 2011. 
ways. Single factors can sometimes only be important ingredients where they are able to interact productively with other ingredients. Further research is necessary to understand better why one factor relates to another factor in a certain way and not another, why a certain combination of factors interact positively to trigger atypical performance but not another combination, and whether there is a necessary ingredient that, as in chemistry, will serve as a catalyser for atypical performance. Many authors argue that this catalyser is leadership (Leonard, 1991; Grindle, 1997; Bebbington and McCourt, 2007). I argue that leadership needs to be disaggregated to political and organisational levels and that it is necessary for both to exist if atypical performance is to be achieved and sustained. Leadership is, of course, important, but is not a silver bullet. My focus instead has been on the amalgam that holds leadership and all other important factors together in such a way as to make atypical performance possible. That amalgam, in my view, is demand.

I have argued that the combined elements of pressure, power and passion have a conjunctural effect on each other. Similarly, David Booth argues for the need to break away from the usual language of necessary and sufficient causes. He recommends, sensibly in my view, for outcomes that are causally associated with particular combinations of the identified variable and not others. This would facilitate the development of theory in which the possible combinations of variables are examined in relation to empirical evidence (Booth, 2010, p.34). This is what I have tried to do here.

\subsection{Conclusion}

In this chapter, I have attempted to develop a new theory of convergent demand, based on my empirical findings. I would conclude this section by arguing that the combination of convergent demand and the internal and external factors that I explored in my empirical work makes atypical performance more likely, than if that combination did not exist. Most authors have focused on the internal variables such as leadership, 
performance management or pay (Grindle, 1997; Uphoff, 1998, Owusu, 2005; Waal, 2007). Others have focused on political economy and its effects on organisational performance (Leonard, 2006; Bebbington and McCourt, 2007). Within that political economy argument, I have sought to identify the gel that holds the key factors at play together, and to show that they must interrelate with the internal variables, in a particular way, if atypical performance is to be possible. 


\section{Chapter 9 Unfinished Business}

Now this is not the end. It is not even the beginning of the end. But it is, perhaps, the end of the beginning (Churchill, W., 1942).

This chapter concludes this dissertation. In coming to this point, I would hope that I have made some contribution to the debate on the phenomenon of strong organisations in weak states. Knowledge about this issue is important. There is a plethora of ideas and propositions about how to achieve improved organisational performance in developing countries. These ideas are sometimes tautological, incoherent and inconsistent (Leonard, 2007, lists more than 60 propositions on the issue). Most authors also take a factor-oriented, rather than a process-oriented, approach. This makes it difficult for reformers to decide where best to focus efforts and scarce resources. I have assessed both contributions and limitations from the literature. The approaches that I have taken, the choices that I have made, and the new theory that I have proposed in this study, start to provide a new insight into the phenomenon. However, this approach presents the challenges that face any pioneer that comes into uncharted territory: a new insight opens up its own mysteries that require further investigation (Arendt, 1992).

The way that I have set up this study to directly compare organisations performing similar functions, where one appears to be performing well and the other appears not to be, is suited to the type of study that I have undertaken because it tries to distil similarities and differences such that reasons for differentiated performance can emerge. Uphoff, Esman and Krishna (1998) and Grindle (1997) focused only on successful organisations. Others, such as Leonard (1991) studied exceptional managers or successful policies (Grindle and Thomas, 1991; and Bebbington and McCourt, 2007). My broader approach in looking at the interplay between internal and 
external factors and studying the processes through which atypical performance occurred has resulted in a plethora of new insights and has helped to navigate through the sometimes inconsistent, tautological and confusing literature on the subject. However, this pioneering approach has raised many searching questions to which this study can only provide partial answers. Why does the government have two organisations performing virtually identical functions? Why does it appear to be more supportive of one (usually the latter creation) than the other? Why does the elite in a society sometimes appear to be willing to give up some of its power and allow atypical performance in some cases but not in others? Why do inefficient organisations and institutions persist?

I will start this concluding chapter first by collating what my contribution may have been over the course of the dissertation. This will involve a brief commentary on my approach to the study, the body of literature on the subject, the methodology adopted, the key findings from my empirical studies and my attempt at generating a new theory. The second part of this chapter will look at the limitations and inadequacies of my effort and identify opportunities for further research and analysis.

\subsection{Contributions to Knowledge}

Claiming to have made a contribution to knowledge is a brave thing to do. Claiming to have developed something new requires even more bravery, given that someone is supposed to have said in 1899 that "Everything that can be invented has been invented" (Author Unknown). ${ }^{51}$ However, in whatever light my contribution is seen, I would hope that the approaches that I have taken, my analyses of concepts and my perspectives on empirics would have provided a fresh vista on the subject matter.

\footnotetext{
${ }^{51}$ This quote is often attributed to Charles Holland Duell of the U.S. Patent Office, but there are now real doubts that he was indeed the author.
} 


\section{Approach to the Study}

In conducting this study, I adopted the somewhat 'atypical' approach of evidence-based research or design-oriented research. This approach relies on practitioner experience about what has worked in the past and therefore has the strongest basis of empirical support for attaining desired outcomes in the real life environment. Although I adopted the Popperian Empirical Falsification approach to ensure that the empirical findings are valid and robust, I have avoided devil-advocacy for its own sake. I have not been afraid to tell a positive story when there appears to be one to tell, and may not always have been constrained by the usual academic tendency for circumspection and reservation, when I did not consider circumspection and reservation necessary. "[...] a man who is circumspect, when circumstances demand impetuous behaviour, is unequal to the task, and so he comes to grief" (Machiavelli, 1999, p.80). My entire dissertation is a statement of informed hope: that even in the midst of the most formidable adversity, the human spirit can prevail and work for the greater good. It demands an impetuous approach. That hope has been informed by studying the phenomenon as a whole, rather than in parts, and focusing on practitioners' experiences and insights in a constantly changing environment. Of course, an impetuous approach can often be tempered by the cold hand of reality and contrary evidence. It is my hope that other researchers will help to refine or even displace some of my ideas, and that these will lead to a better understanding of the phenomenon I have studied here.

\section{Theoretical Concepts}

My study belongs to the mere 5\% of studies that have sought to study institutional theory in developing countries. Hafsi and Farashahi (2005) found that over the last twenty years of empirical research into institutional theory, 95\% focused on developed countries, with only 5\% focusing on developing countries. I considered the role of the state and found that what 
obtains in many African countries is an incoherent mixture of ideologies about the proper role of the state, which, in turn, leads to confused state action.

I discussed the three main schools of thought that dominate the literature on institutional theory (rational choice, historical and sociological) and postulated that the very existence of atypical organisations in weak governance environments, undisputed in the literature, starts to challenge the fatalism of institutional theory.

In reviewing the literature on 'pockets of effectiveness', I noted that most authors simply list the factors that they found in the atypical organisations that they have studied and propose hypotheses on those basis. This has meant that the literature is full of contradictory propositions about what works, many of which are as equally applicable in strong governance environments as in weak ones. I boiled down the dozens of factors into three main external factors and four main internal factors and fitted most of the literature into them. I then adopted these factors as my explanatory variables. What was apparent from my empirical work, however, is that the relationships between dependent and independent variable do not tell the full story. Based on tentative hypotheses, I developed a conceptual framework to use in organising my thinking about the interplay between the external conditions and the internal ones, and for later supporting, refining or disconfirming my working hypotheses.

I also started to explore a 'new' concept of demand and any possible effects that it may have on the interplay between the external and internal factors. In building theory in social science research, there are two fundamental approaches - variance theory and process theory (Mohr, 1982). Variance theory explains variations in a dependent variable as being a result of variations in an independent variable or variables (Mohr, 1982; Chiles, 2003). This approach would suggest that improvements in performance are directly attributable to changes in external and internal conditions, such as 
increased funding. This approach has limitations for the nature of study that I have undertaken.

The variance theoretic approach, rooted in mechanics and logical positivism is appropriate for developing and testing falsifiable theories about simple phenomena, but less suited for theorizing about path-dependent, nonlinear, organic processes in which myriad interactions give rise to complex social phenomena (Chiles, 2003, p.1)

Alternatively, process theory tells a story in terms of occurrences, sequences, time and events and seeks to develop causal explanations that can lead to certain probabilities (Mohr, 1982; Chiles, 2003). I have followed the 'process theory' approach which seeks to provide explanations in terms of patterns of events, activities and choices over time. Sequence and the order of events are critical (Langley, 2008), but so are parallel paths, feedback loops and non-deterministic tangents, interactions and reversals (Van de Ven, 1992). Nevertheless, the theory that emerges at the end is grounded in an underlying logic and the lived experiences that make a particular outcome more likely.

\section{Research Design and Methodology}

The research approach adopted involved taking pairs of organisations performing similar functions in the same field of endeavour and assessing why one is performing well and the other is not. In order to achieve this typology, I had to move beyond perception data, to focus on actual performance against mandates. This was an onerous task, given that many public sector organisations in developing countries do not collect data about how they perform against their stated mandates. I therefore had to identify and apply, from the literature, performance indicators often used in assessing the performance of such organisations. Once I did this, I was able 
to quickly discount the propositions and hypotheses that an organisation's functions determine how well it performs. By showing that two organisations performing similar functions can have widely-differential performance, it called into question the validity of the propositions as to function.

The research design and methodology used has also enabled me to challenge or confirm various other propositions in the literature:

1. In each case study, employees of both organisations studied receive similar pay and conditions of service. Pay was therefore not a factor in explaining why one organisation performed better than the other;

2. By choosing only federal organisations from the same country, headquartered in the same physical environment, operating the same public service rules, bound by the same budgetary provision arrangements, and operating within the same institutional and political economy setting, it became apparent that differential performance is probably as a result of other factors, not institutions in the sense that some institutional theorists claim;

3. By choosing organisations that are politically and economically relevant, I have been able to show that organisations can succeed even where it is not in the economic interest of the power-holding elite for it to do so; and

4. By focusing on outputs as stated in mandates and enabling laws, I have judged performance on those things that the organisation is set up to deliver and that should be within its control, and eschewed the bias that comes from perception and clever manipulation of the media.

Additionally, I have developed, perhaps for the first time in the literature, a number of indicators for determining the existence of a demand for improvement in an organisation or function. Taken together, I hope that the 
approaches taken here will help to generate other research that will deepen our knowledge about the phenomenon of atypical performance in dysfunctional states.

\section{Empirical Findings}

The empirical chapters support the following unsurprising proposition: Leadership, Management, Technical Capacity and Public Support are as important for good organisational performance in weak governance environments as in strong ones. They also show that institutions matter but can be overcome, and start to highlight the role of the activist political and organisational leader.

An interesting finding is with regards to the replicability of reforms between organisations. Many authors hope that demonstrations of successful reforms can be replicated more widely and used to reform the entire public service. However, this does not often happen, which is why we still have pockets of effectiveness in developing countries. What I have found instead, is that this replicability is more likely between organisations performing broadly similar functions where certain conditions exist. The chances of imbibing good practice appear to be even higher when one chief executive sits on the board of a similar organisation. SON sits on the board of NAFDAC and appears to have imported some of the reforms that took place in NAFDAC. Similarly, NCS and FIRS sit on each other's boards and NCS seems to have learnt a number of productive initiatives from FIRS.

The case studies also further explore the emerging concept of demand in an iterative and progressive way, building on my knowledge of the concept and deepening it with each case study.

A cross-case analysis at the end of the empirical chapters organised what I had learnt, in a comparative way, in one place. 


\section{Towards a New Theory}

I am probably guilty of two cardinal sins in writing a $\mathrm{PhD}$ dissertation: attempting to develop a new theory, and coming up with a new term, 'convergent demand' (Dunleavey, 2003). This 'sin' is difficult to avoid, given that the variance theory approach adopted by most commentators on the subject is inadequate in studying complex social phenomena such as atypical performance in dysfunctional environments. I have argued that while various variance factors may be important, they need a glue to hold them together and that that glue is demand. The process approach that I have taken suggests to me very strongly that where there is convergent demand, atypical performance is more likely in weak institutional environments. However, we are only at the starting point of fully understanding how this works. It seems to me therefore that my proposed theory satisfies one of the key requirements of good theory - the ability for it to be falsified. I invite other researchers to do so and thereby deepen our knowledge.

\subsection{Limitations and Opportunities for Further Research}

The benefits accruing from the way that I have set up this study also brings with it some attendant limitations.

\section{Limitations}

The pioneering approach taken to researching this dynamic topic necessarily meant that I was exposed to information for which there was limited guidance in the literature. I have therefore had to struggle to make sense of certain observations and occurrences, such as issues of patriotism, activist leadership and providing remuneration outside the usual public service rules in order to secure the right organisational leader. However, this is a limitation that I consciously accepted from the start of the study. 
In focusing performance on outputs, the study necessarily ignored other softer attributes and did not necessarily evaluate all interrelated functions. For instance, it was put to me quite strongly that the border protection and trade facilitation roles of the Nigerian Customs Service were inextricably intertwined with its revenue collection role and cannot be divorced when assessing performance. The persistent allegations against NCS (that it is indeed collecting far more revenue than it reports and that it retains the bulk of it for corrupt purposes) shows that an organisation that merely delivers its outputs may not necessarily be one that can be recommended to other organisations as an example of good practice.

Also, an organisation that has multiple and complementary mandates may feel that the performance indicator used to assess its performance was incomprehensive and unfair. For instance, ICPC has a mandate for conducting system reviews and civic education, into which it has ploughed most of its efforts. The system reviews strengthen government process and block the loopholes through which public servants can corruptly enrich themselves. It is difficult to quantify the value of this for measurement purposes. The same can be said about its efforts at civic education, such as including an anticorruption module in the curriculum for secondary school students.

Lastly, even where an organisation is delivering its outputs, like EFCC is, once it loses credibility and public support, actual performance pales into insignificance. Therefore, delivering outputs alone is not enough.

Many of my empirical findings are symptomatic of the plethora of observations thrown up by the atypical approach I have taken to this study, for which there is little guidance in the literature.

Focusing the study on only one country raises questions as to the extent to which the findings can be generalised beyond the environment in which the study took place. It could be argued that this was a study of atypical organisations in an atypical country, and that any findings are likely to be idiosyncratic. Although the issues addressed are of general application, 
even to good governance environments, and I have taken every care to eschew some of the idiosyncratic nuances of the Nigerian environment, the findings and the proposed theory would benefit from being tested in another country or across countries. Also, the empirical work only covers 6 organisations. The findings would have been more robust if it had been possible to extend it to more organisations or to different levels of government, such as state governments or local governments.

Finally, the research is based on Nigeria where I was born and currently work. This confers the advantage of giving me very good access to key actors and agents (including current and previous senior government officials) and even the former President of the country. This provides richness to the study but also presents a higher risk of bias than may otherwise have been the case if I was undertaking a quantitative study or studying an unfamiliar environment.

\section{Opportunities for Further Research}

I embarked on the study suspicious that there was a gap in the literature. I have by no means addressed all the gaps in the literature. There is still much more to learn about this phenomenon. To do so, it is possible to extend the scope of the current study to include more organisations, study similar organisations in a different institutional context, improve the theory that I proposed and apply more quantitative methodological approaches. In addition to the opportunities for further research which addressing the limitations above will automatically provide, three main areas stand out as candidates for future research.

The role of the activist leader is, in my view, currently under-explored in the literature. Institutional theorists have so dominated theoretical thinking on governance that the role of the individual in affecting change has been greatly diminished. 
There is an opportunity to further research the transferability of good practice between organisations that perform similar functions, particularly where their chief executives sit on each other's boards. This is to be distinguished from the usual, more-ambitious, aim of wider transferability to the rest of the public service.

The third main opportunity for further research would be to test my proposed convergent demand theory in more cases or in another environment.

In the quote at the very beginning of this book, Nietzsche was probably being too hard on himself in his self-criticism of his own book. Indeed, he may have been being facetious or dialectical. Applying that level of criticism to my own book may similarly be too harsh. In conclusion, I hope that it is a book through which "the educated", fellow practitioners (or "rhapsodizers"), non-initiates and other folk can discover new paths.

Every new beginning comes from some other beginning's end - Seneca ${ }^{52}$

\footnotetext{
${ }^{52}$ Lucius Annaeus Seneca (The Younger), Roman Philosopher (c. 3 BCE - AD 65). Downloaded from the internet on 23 April, 2012 at http://plato.stanford.edu/entries/seneca/
} 
References and Additional Information 


\section{References}

Abdullahi, D, (2012), How the Nigeria Customs Service Secured Political Support, downloaded from the internet on 2 March 2012 at http://www.wcoomd.org/meetings/hrds/aps\%20external\%20documents/HC _Item6_Nigeria_E.pdf

Acemoglu, D. (2006), Modelling Inefficient Institutions, NBER Working Paper Series, Vol. w11940.

Achebe, C., (1983), The Trouble with Nigeria, Fourth Dimension Publishing Company Limited.

Adamolekun, L., (2002), Public Administration in Africa, Spectrum Books Limited

- (2003), Politics and Administration in Nigeria, Spectrum Books Limited

- (2007), Creating a Responsive and Citizen-Focused Public Service in Africa: An Overview. Paper presented to the Commonwealth Secretariat: Fourth Forum of African heads of Public Services.

- (2008), The Governors and the Governed, NNMA Award Winners Lecture, December 3, 2008, Ibadan: Spectrum Books Limited.

Adebanwi, W., (2010), A Paradise for Maggots: The Story of a Nigerian AntiGraft Czar, Wale Adebanwi, Publisher.

Aguda, T., (1974), The Law of Evidence in Nigeria, second edition, Sweet and Maxwell, London.

Ake, C., (1978), Revolutionary Pressures in Africa, Zed press

Akude, J., (2007), The failure and collapse of the African state: on the example of Nigeria, FRIDE, Comment, September 2007.

Akunyili, D., (2010), One Woman's Fight Against Fake Drugs, in Selected Speeches by Prof. Dora Nkem Akunyili, Prestige, p.906. 
- (2010), The War Against Counterfeit Medicine: My Story, Safari Books, Ibadan.

Alavi, H., (1982), State and class under peripheral capitalism, in Alavi, H. And Shanin, T. (eds.), Introduction to the Sociology of "Developing Societies", London: Monthly Review, pp. 289-307.

Abidjan-Lagos Corridor Organisation (2011), Abidjan-Lagos Trade and Transport Facilitation Project, p.3.

Amundsen, I., (2010), Good Governance in Nigeria: A Study in Political Economy and Donor Support, Norwegian Agency for Development Cooperation.

Amuwo, A., (2009), The Political Economy of Nigeria's Post-military Elections, 1999-2007, Review of African Political Economy No. 119:37-61

Aoki, M., (2001), Towards a Comparative Institutional Analysis. MIT Press

Apampa, O., (2006), Do Right Do Well: Compliance and the Market Mechanism (Conceptual Analysis), Convention on Business Integrity.

Arendt, H., (1998), The Human Condition, 2nd Edition, University of Chicago Press

Armstrong, M., and Baron, A., (1988), Performance Management; The New Realistic, Institute of Personnel and Development, London.

Athreye, S., (2011), Overcoming Adversity in Entrepreneurship-led Growth: Evidence from the Indian Software Sector, in Szirmai, A., Naude, W. And Goedhuys, M., (eds.), Entrepreneurship, Innovation and Development, chapter 11, Oxford University Press.

Author unknown, (2011), "Re: Ribadu begins working visit to Liberia", author unknown, accessed from the internet on 2 June 2011 at http://www.nairaland.com/nigeria/topic-312493.0.html

Barber, M. (2007), Instruction to Deliver, London: Politico 
Bardhan, P., (1984), The Political Economy of Development in India, Oxford University Press.

Barnes, M., (date unknown), accessed from the internet on 4 November 2011 at http://www.inspirationalstories.com/quotes/t/michael-d-barnes-on-lawregulation/

Bate, R., Ayodele, T., Tren, R., Hess, K., and Sofola, O., (2009), Drug Use in Nigeria, Africa Fighting Malaria, American Enterprise Institute and the Initiative for Public Policy Analysis Working Paper, August 2009.

Bebbington, A. and McCourt, W, (2007) Development Success: Statecraft in the South, Basingstoke: Palgrave Macmillan

Belaya, V. and Hanf, J., A multi-theoretical perspective on power in managing organisational relationships, International Journal of Social Economics, Vol. 36, Issue 11, pp. 1040-1049.

Bell, S., (2002), Institutionalism: Old and New, in Woodward, D., (ed), Government, Politics, Power and Policy in Australia, $7^{\text {th }}$ Edition, Melbourne, Longman.

Bentley, A., (1949), The Process of Government, Evanston, Illinois, Principia Press.

Berlin, I., (1995), Liberty. Oxford University Press.

Besley, T., (2006), Principled Agents?: The Political Economy of Good Governance, Oxford University Press.

Bevir, M. And Rhodes, R., (2001), A Decentered Theory of Governance: Rational Choice, Institutionalism, and Interpretation, Working Paper 2001-10, Institute of Governmental Studies, University of California, Berkeley.

Blumberg, B., Cooper, D. and Schindler, P., (2008), Business Research Methods, $2^{\text {nd }}$ European Edition, McGraw Hill. 
Boesen, N. and Therkildsen, O., (2005), A Result Oriented Approach to Capacity Change, Danish Institute for International Studies.

Bolongaita, E., (2010), An exception to the rule? Why Indonesia's Anticorruption Commission succeeds where others don't - a comparison with the Philippines Ombudsman, U4 Issue, August 2010, No. 4, U4 AntiCorruption Resource Centre.

Booth, D., (2010), Towards a theory of local governance and public goods provision in sub-Saharan Africa, Working Paper No. 13, African Power and Politics, Overseas Development Institute.

Boyne, G., and Meier, J., (2009), Environmental Turbulence, Organisational Stability, and Public Service Performance, Administration and Society, Vol. 40, No.8, pp. 799-824.

Boyne, G., Meier, G., O’Toole Jr., and Walker, R., (eds.,) (2006), Public Service Management: Perspectives on Measurement and Management, Cambridge University Press.

Braithwaite, J., (2007), Can Regulation and Governance Make a Difference?, Regulation and Governance, 1, pp.1-7.

Brown, A, (2006), Measuring Effectiveness of Regulatory Agencies, accessed from the internet on 18 March, 2012 at http://www.hks.harvard.edu/hepg/brown_papers/ABrown_WB_Regulation _306.pdf

Business Day, 2010, Long list of banned goods promotes corruption in customs - World Bank, edition of Thursday 16 November 2010, downloaded from the internet on 2 March 2012 at http://www.businessdayonline.com/NG/index.php/news/76-hottopic/16173-long-list-of-banned-goods-promotes-corruption-in-customsworld-bank-

Buyonge, C., (2008), Organisational Design of Customs in Sub-Saharan Africa: A Critical Evaluation, World Customs Journal, October 2008, Volume 2, Number 2, p.53. 
Cabinet Office, UK, (2007), Building on progress: The role of the state, accessed from www.cabinetoffice.gov.uk/policy_review on $4^{\text {th }}$ January, 2010.

Cabral, A., (1974), Return to the Source: Selected Speeches, Monthly Review Press

Calvert, R., (1995), "Rational Actors, Equilibrium and Social Institutions", in Knight, J. And Sened, I., editors, Explaining Social Institutions, University of Michigan Press.

Carroll, L., (1865), Alice's Adventures in Wonderland, in The Little Oxford Dictionary of Quotations, 1994, edited by Susan Ratcliffe, Oxford University Press, p. 27

Chika, A, Bello, S., Jimoh, A., and Umar, M., (2011), The Menace of Fake Drugs: Consequences, Causes and Possible Solutions, Research Journal of Medical Sciences, Volume 5, Issue 5, pp. 257-261, downloaded from the internet on $20 \quad$ March 2012 at http://www.medwelljournals.com/fulltext/?doi=rjmsci.2011.257.261.

Chiles, T., (2003), Process Theorizing: Too Important to Ignore in a Kaleidic World, Academy of Management Learning and Education, Vol. 2, No. 3, pp. 288-291.

Chinafrica, (2011), Quality Management VS Quality Control, Business Ease, downloaded from the internet on 31 March, 2011, at http://www.chinafrica.cn/english/business ease/txt/201102/28/content 334304.htm .

Churchill, W., (1942), in The Little Oxford Dictionary of Quotations, 1994, edited by Susan Ratcliffe, Oxford University Press, p. 27.

Clarke, J., (2004), Dissolving the Public Realm? The Logics and Limits of Neo- liberalism, Cambridge Journals, Jnl.Soc.Pol, 33,1,27-48 
CLEEN Foundation, (2005), National Crime Victimisation Survey, accessed from the internet on 4 June 2011 at http://www.unodc.org/documents/dataand-analysis/dfa/Review_Indicators_EFCC.pdf

Cohen, S., (1993), Building Sustainable Public Sector Managerial, Professional and Technical Capacity: A Framework for Analysis and Intervention, Development Discussion Paper 473, Cambridge M.A.: Harvard Institute for International Development.

Collier, P., (1996), Living Down the Past: Redesigning Nigerian Institutions for Economic Growth, African Affairs, 95, pp. 325-250.

Collins, J., (2001), Good to Great. Harper Collins.

Convention of Business Integrity, (2009), Public Perception of the AntiCorruption Agencies.

Dahl, R., (1959), The Concept of Power, Behavioural Science, 2, pp. 201-215.

- (1961), Who Governs? Democracy and Power in an American City, Yale University Press.

Daily Trust, (2010), FIRS Rakes in 1.7 Trillion in 8 Months", 7 October 2010, accessed from the internet on 11 November, 2010, at http://allafrica.com/stories/201010070459.html .

- (2011a), Civil Society Lauds Rejection of ICPC Chair Nominee, 14 February, 2011, accessed from the internet the same day at http://dailytrust.dailytrust.com/index.php?option=com_content\&view= article\&id=12019:civil-society-lauds-rejection-of-icpc-chair-

nominee\&catid $=1$ :news\&Itemid $=2$

- (2011b), We have done better than Ribadu, says Farida, 7 March, 2011, accessed from the internet on the same day at http://www.dailytrust.com.ng/index.php?option=com_content\&view=a rticle\&id=13504:we-have-done-better-than-ribadu-saysfarida\&catid=2:lead-stories\&Itemid $=8$

- (2011), ICPC: NAFDAC Illegally Spent N14b Revenue, edition of 22 June, 2011. 
DiMaggio, P. and Powell, W., (1991), The New Institutionalism in Organisational Analysis, Chicago, Chicago University Press.

Dowden, R., (2009), Africa: Altered States, Ordinary Miracles, Portobello Books.

Dunleavey, P., (2003), Authoring a PhD: How to Plan, Draft, Write and Finish a Doctoral Thesis or Dissertation, Palgrave Macmillan.

Economic Confidential, (2010), Re: 'Senators, Ministers Hijack 524 Jobs in FIRS': Facts, downloaded from the internet on 4 March 2012 at http://economicconfidential.net/new/financial/tax-matters/417-re-senatorsministers-hijack-524-jobs-in-firs-facts )

- (2010a), FIRS Boss Slams N10bn Suit Against Newspaper, Consultant, downloaded from the internet on 4 March, 2012 at http://economicconfidential.net/new/financial/tax-matters/276-firs-bossslams-n10bn-suit-against-newspaper-consultant

EFCC, (2010), The Impact is Real", in Our Milestone, A Special Publication of Nigeria's Economic and Financial Crimes Commission, Vol. 1, No 1, May 2010, p.14

Eisenhardt, K., (1989), Building Theories from Case Study Research, Academy of Management Review, 1989, Vol.14, No. 4, pp. 532-550.

Ekeh, P., (1975), Colonialism and the Two Publics: A Theoretical Statement, Comparative Studies in Society and History, Vol.17, No. 1, pp. 91-112.

Esman, M. and Uphoff, N. (1984), Local Organisation: Intermediaries in Rural Development, Ithaca: Cornell University Press

Evans, P., (1995), Embedded Autonomy: States and Industrial Transformation, Princeton: Princeton University Press.

Fanon, F., (1963), The Wretched of the Earth, Penguin Classics 
Federal Government of Nigeria, (1971), Nigeria Standards Organisation Act, No. 56 of 1971

- (1976), Nigeria Standards Organisation Amendment Act

- (1984), Nigeria Standards Organisation Amendment Act

- (1990), Standards Organisation of Nigeria Act, Chapter 412, Laws of the Federation of Nigeria

- (1991), The Banks and other Financial Institutions Act, 1991

- (1993), National Agency for Food and Drug Administration and Control Act, Decree No 15 of 1993.

- (1994), The Failed Banks (Recovery of Debts) and Financial Malpractices in Banks Act, 1994

- (1995), The Money Laundering Act, 1995

- (1999), Constitution of the Federal Republic of Nigeria, Federal Government Press

- (1999a), National Agency for Food and Drug Administration and Control Amendment Act, Decree No 19 of 1999.

- (2000), The Corrupt Practices and Other Related Offences Act, 2000

- (2002), Economic and Financial Crimes (Establishment) Act, 2002

- (2003), Nigerian Tax System in 2003 and Beyond

- (2004), Economic and Financial Crimes (Establishment) Act, 2004

- (2004a), The Miscellaneous Offences Act, 2004

- (2004b), The Money Laundering (Prohibition) Act, 2004

- (2004c), National Economic Empowerment and Development Strategy, National Planning Commission, Nigeria.

- (2004d), Customs and Excise Management Act

- (2006), The Advance Fee Fraud and Other Fraud Related Offences Act, 2006

- (2007), Federal Inland Revenue Service (Establishment) Act

- (2008), National Strategy for Public Service Reform, Unpublished

Federal Inland Revenue Service Modernisation Plan, 2004-2007.

- Federal Inland Revenue Service Establishment Act of 2007

- Federal Inland Revenue Service Corporate Plan, 2010.

Fitzallen, N. and Brown, N., (2007), Evidence-based research in practice, in Engaging Pedagogies, 26-30 November, accessed from the internet on 8 January 2012 at http://eprints.utas.edu.au/4857/ 
Fitzgerald, L. and Moon, P., (1996), Performance measurement in Service Industries: Making it Work, CIMA, London.

Foucault, M., (1990), The History of Sexuality: An Introduction, Volume 1, New York, Vintage Books.

- (1995), Discipline and Punishment, New York, Vintage Books.

Gallup, (2005), Brand Piracy: A Victimless Crime?, accessed from the internet on 22 march 2012 at http://www.gallup.com/poll/15088/brand-piracy-victimlesscrime.aspx

Gana, A., (1985), The State in Africa, Yesterday, Today and Tomorrow, International Political Science Review, Vol. 6, No. 1, p. 123, The Future of the State, pp. 115-132.

Gauld, R., (2007), Principal-Agent Theory and Organisational Change, Policy Studies, Vol. 28, No.1.

Ghosal, S. and Proto, E., (2009), Democracy, collective action and intra-elite conflict, Journal of Public Economics, 93, pp. 1078-1089.

Giddens, A., (2002), Runaway World, Profile Books.

- (2009), The Third Way, Polity Press.

Gillies, A., (2007), Obasanjo, the Donor Community and Reform Implementation in Nigeria, The Round Table: The Commonwealth Journal of International Affairs, Vol.96, No. 392, pp. 569-586, October 2007.

- (2009), U4 Brief, accessed from the internet on 16 April 2011 at http://www.radnetwork.org/admindb/docs/GGillies\%20Nigeria\%20Bri ef.pdf

Gorham, G., The Philosophy of Science, A Beginners Guide, One World Publications, p. 73. 
Gowon, Y., (date unknown), accessed from the internet on 10 November, 2011 at http://en.wikipedia.org/wiki/Yakubu_Gowon

Gray, G., (2004), Concise Guide to Evidence-based Psychiatry, American Psychiatric Publications, Washington, D.C.

Greif, A., (2006), Institutions and the Path to the Modern Economy. Cambridge University Press.

Grindle, M. and Thomas, J., (1991), Public Choice and Policy Change: The Political Economy of Reform in Developing Countries, Baltimore: The John Hopkins University Press.

Grindle, M., (1997), Divergent Cultures? When Public Organisations Perform Well in Developing Countries, World Development, Vol.25, No.4, pp.481-495.

Guardian, (2011), Influx of substandard goods worrisome says SON, 30 May, 2011.

- (2012), How to rid Nigerian market of substandard goods, by Odumodu, accessed from the internet on 20 March, 2011 at http://www.ngrguardiannews.com/index.php?option=com_content\&vi ew=article\&id=74166:how-to-rid-nigerian-market-of-sub-standardgoods-by-odumodu\&catid=89:industry-watch\&Itemid=594

Gunn, C., (2004), Evidence Based Research in Education. Downloaded from the internet on 5 January 2012 at www.alt.ac.uk/alt2004/altc2004_documents/cathy_gunn.ppt

Hafsi, T. and Farashahi, M., (2005), Applicability of management theories to developing countries: a synthesis, Management International Review, October 2005.

Hall, P. and Taylor, R., (1996), Political Science and the Three New Institutionalisms, Political Studies, XLIV: 936-57 
Held, D. and Hirst, P., (2002), Globalization: The Argument of Our Time, Centre for Bhutan Studies.

Heredia, B. And Schneider, B. (2002) 'The Political Economy of Administrative Reform in Developing Countries', in B.R. Schneider and B. Heredia (eds.), Reinventing Leviathan: The Politics of Administrative Reform in Developing Countries, Miami: North-South Centre Press: 1-29.

Heymans, C. and Pycroft, C., (2005), Drivers of Change in Nigeria: Towards Restructuring the Political Economy, Department for International Development.

Heywood, A., (2002), Politics, Palgrave Macmillan, $2^{\text {nd }}$ Edition.

Hilderbrand, M., Grindle, M., (1994), Building Sustainable Capacity: Challenges for the Public Sector, Prepared for UNDP, accessed from the internet on 1 March, 2012, at http://mirror.undp.org/magnet/cdrb/parti.htm

Hobbes, T., (2008), Leviathan, Oxford World Classics, Oxford University Press.

Hofstede, G. (2001), Culture's consequences - comparing values, behaviours, institutions and organisations across nations. $2^{\text {nd }}$ edition, Sage publications, Thousand Oaks.

Holdt, v. K., (2009), The South African Post-Apartheid Bureaucracy: Inner Workings, Contradictory Rationales and the Developmental State. Unpublished

Human Rights Watch, (2011), Corruption on Trial?: The record of Nigeria's Economic and Financial Crimes Commission, Human Rights Watch

Ibrahim Foundation (2010), The Ibrahim Index, accessed from the internet at http://www.moibrahimfoundation.org/en/section/the-ibrahim-index on 7 November, 2010.

Ikenberry, G., (1994), History's Heavy Hand: Institutions and the Politics of the State, presented at a conference on New Perspectives of Institutions, 
University of Maryland, accessed from the internet on 28 April, 2011, at http://www.princeton.edu/ gji3/HistorysHeavyHand.pdf .

Ikubaje, J., (2006), Corruption and Anti-corruption: Revenue Transparency in Nigeria's Oil Sector, Joe-Tolalu and Associates, p.ix.

International Anti-counterfeiting Coalition (undated), Facts on Fakes, downloaded from the internet on 20 March 2011 at http://www.fnal.gov/directorate/OQBP/sci/sci_reference_docs/SCI\%20Facts _on_fakes.pdf .

Institute of Development Studies (2010), An Upside-down View of Governance, University of Sussex.

Institute of Public Analysts of Nigeria (2011), accessed from the internet on 23 October, 2011, at www.ipanng.org./AboutUs.php

Internet Centre for Corruption Research, (Undated), Frequently Asked Questions, accessed from the internet on 6 June, 2011 at http://www.icgg.org/corruption.cpi_2004_faq.html

Jackson, P., (1988), The Management of Performance in the Public Sector, Public Money and Management, Winter 1988, pp. 11-16.

Jalilian, H., Kirkpatrick, C., and Parker, D., (2006), The Impact of Regulation in Economic Growth in Developing Countries: A Cross-Country Analysis, accessed from the internet on 10 November, 2011, at https://dspace.lib.cranfield.ac.uk/bitstream/1826/1455/1/Impact\%20of\%20reg ulation-Economic\%20growth-March06.pdf

Jinadu, A., (2009), Strengthening the Regulatory Role of the African State: The Approach of the African Peer Review Mechanism (APRM), paper prepared for presentation at the 31 ${ }^{\text {st }}$ AAPAM Roundtable Conference, The World Economic Crisis: Challenges to the African Public Administration Systems, [Sub-theme 6.4, Strengthening the Regulatory Role of Public Administration Systems], 21-25 September, 2009, Nairobi, Kenya. 
Johnston, M. and Kpundeh, S., (2004), Building a Clean Machine: AntiCorruption Coalitions and Sustainable Reform, World Bank Policy Research Working Paper 3466, World Bank.

Johnston, M., (2005), Syndromes of Corruption, Cambridge University Press.

Kandinsky, W. and Sadler, M.T., (1997), Concerning the Spiritual in Art, Dover Publications, Inc, p. 35.

Kauffman, D., and Kraay, A., (2002), Growth Without Governance, Mimeo, Washington DC, World Bank.

Kaufman, R., (2003), 'The Comparative Politics of Administrative Reform: Some Implications for Theory and Practice', in B.R. Schneider and B. Heredia (eds.), Reinventing Leviathan: The Politics of Administrative Reform in Developing Countries, Miami: North-South Centre Press: 281-302.

Keynes, J., (date unknown), downloaded from the internet on 27 February 2012 at http://www.financeware.com/ruminations/wems/01.21.04/AM_01.21.04.new budgetproposals.pdf

Kingston, C. and Caballero, G., (2006), Comparing Theories of Institutional Change. Downloaded from the internet on 11 January 2012 at http://www.isnie.org/ISNIE06/Papers06/04.1/kingston.pdf

Kloeden, D., (2011), Revenue Administration in Anglophone Africa Since the Early 1990s, IMF Working Paper WP/11/162, International Monetary Fund.

Laehreid, P., Verhoest, K. And Jann, W., (2008), The Governance, Autonomy and Coordination of Public Sector Organisations, Public Organisation Review, Volume 8, No. 2 (2008), pp.93-96.

Laffont, J., (1999), Competition, Regulation and Development, in Plescovic, B., and Stiglitz, J. (eds.), Annual World Bank Conference on Development Economics 1998, Washington DC, World Bank, pp. 237-257. 
Langley, A., (2008), Studying Processes in and around Organisations, downloaded from the internet on 23 April, 2012 at http://web.hec.ca/geps/Langley.pdf

Leadership, (2011), Scorecard of Dikko's 2 years in office, edition of 23 August 2011,

Leonard, D., (1991), African Successes: Four Public Managers of Kenyan Rural Development, Berkeley; University of California Press.

- (2006) The Political Economy of International Development and Pro-Poor Livestock Policies: A comparative Assessment: Revised and Expanded, PPLPI Working Paper 12, Rome: Food and Agriculture Organisation.

- (2008), Where are 'Pockets' of Effective Agencies Likely in Weak Governance States and Why? A Propositional Inventory. IDS Working Paper 306. Institute of Development Studies, University of Sussex.

Libecap, G., (1989), Contracting for Property Rights, Cambridge University Press

Locke, J., (1988), Two Treatises of Government, Cambridge University Press, edited by Laslett, $\mathrm{P}$.

Lynn, L., Heinrich, C., and Hill, C., (2000), Studying governance and public management: Challenges and prospects, Journal of Public Administration Research and Theory, 10, pp. 233-261.

Maathai, W., (2011), Wangari Maathai, Obituary in the Telegraph, downloaded from the internet on 8 January 2012 at http://www.telegraph.co.uk/news/obituaries/politicsobituaries/8790642/Wangari-Maathai.html 
Machiavelli, N., (1999), The Prince, Penguin Classics, translated with notes by Bull, G., p.20.

- (2009), Discourses on Livy, Oxford World's Classics, Oxford University Press, translated by Bondanella, C., p.99

Makhaya, G., (2002), The Determinants of Regulatory Effectiveness in Liberalised Markets: Developing Country Experiences, Trade and Industry Secretariat Working Paper 4, p.9).

McNamara, C., (1999), Basic Definition of Organisation, accessed from the internet on 2 May, 2011 at http://208.42.83.77/org_thry/org_defn.htm

McNeil, M. and Malena, C., eds., (2010), Demanding Good Governance: Lessons from Social Accountability Initiatives in Africa, The World Bank, Washington DC.

McNeil, M. and Mumvuma, T., (2006) Demanding Good Governance: A Stocktaking of Social Accountability Initiatives by Civil Society in Anglophone Africa, The World Bank, Washington DC.

Meagher, P., (2002), Anti-Corruption Agencies: A Review of Experience, Final Paper, Revised Draft, submitted to the World Bank PREM-ECA, August 2, 2002.

Mendonca, M. and Kanungo R.N., (1996), Impact of culture on performance management in developing countries, International Journal of Manpower, Vol. 17 No. 4/5, pp 65-75, Canada: MCB University Press.

Meredith, M., (2006), The State of Africa, A History of Fifty Years of Independence, The Free Press.

Miles, M. and Huberman, M., (1994), Qualitative Data Analysis: An Expanded Sourcebook, Sage Publications

Mills, J.S., (1987), The Logic of the Moral Sciences, Duckworth. 
Mintzberg, H., (1979), An Emerging Strategy of 'Direct' Research, Administrative Science Quarterly, 30, pp. 160-197.

Mkandawire, T., (1998), Thinking about Developmental States in Africa, Paper presented at the UNU-AERC Workshop on Institutions and Development in Africa held at the UNU Headquarters, Tokyo, Japan, October 14-15. Accessed from the internet on 5 January 2010 at www.unu.edu/hq/academic/Pg_area4/Mkandawire.html .

Mohr, L., (1982), Explaining Organisational Behavior, San Francisco, California, Jossey-Bass.

Momoh, A., (2010), Policing Corruption and Financial Crimes: Understanding the structure of the EFCC, FES, Unpublished Draft

Mwita, J., (2000), Performance Management Model: A systems-based approach to public service quality, The International Journal of Public Sector Management, Vol. 13, No.1, pp 19 - 37.

Nation, (2009) Vaswani's N2.5b waiver: EFCC re-arrests ex-Customs boss, three others, edition of 12 August 2009, downloaded from the internet on 23 March 2012 at http://thenationonlineng.net/web2/articles/13816/1/VaswanisN25b-waiver-EFCC-re-arrests-ex-Customs-boss-three-others/Page1.html ).

- (2010), Yar'adua, the man, Edition of 6 May, 2010, downloaded from the internet on 23 March, 2012 at http://thenationonlineng.net/web2/articles/45485/1/YarAdua-theman/Page1.html

National Agency for Food and Drugs Administration and Control, (undated), Information Brochure, obtained on 26 June, 2011.

National Bureau of Statistics, Annual Abstract of Statistics, 2005-2009.

National Mirror, (2012), Jonathan Fires Ringim, Appoints Acting IG of Police, edition of 25 January 2012, accessed from the internet on 13 March 2012 at http://nationalmirroronline.net/breaking-news/29837.html. 
NBS/ EFCC, (2007), Business Survey on Crime and Corruption and Awareness of EFCC in Nigeria, published December, 2009.

NEPAD (2010), Objectives, Standards, Criteria and Indicators for the African Peer Review Mechanism, accessed from the internet at http://www.nepad.org/economicandcorporategovernance/african-peerreview-mechanism/about on 7th November 2010.

Newswander, C., (2011), Foucauldian Power and Schmittian Politics: The Craft of Constitution, Administration and Society, 43(5), pp. 537-560.

Next Newspaper, accessed from the internet from http://234next.com/csp/cms/sites/Next/Home/5444428-146/story.csp on 25 October, 2010

- (2010), Agencies ask government to check counterfeiting, Next newspaper, 9 November, 2010, accessed from the internet at http://234next.com/csp/cms/sites/Next/Money/Business/5540473146/agencies_ask_government_to_check_counterfeiting.csp

- (2010a), Agencies helpless as counterfeit products increase, Next newspaper, 9 November, 2010

- (2011), America Humiliates Waziri”, March 14, 2011, accessed from the internet on 1 June 2011 at http://234next.com/csp/cms/sites/Next/Home/5682708-146/story.csp

Nietzsche, F., (2000), The Birth of Tragedy, Oxford World Classics. A new translation by Smith, D.

Nigeria Compass Newspaper, accessed from the internet from http://www.compassnewspaper.com/NG/index.php?option=com_content\& view=article\&id=68934:customs-n100-million-gift-causes-row-inreps\&catid=43:news\&Itemid=799 on 25 October 2010.

Nigeria Population Commission, (2011), accessed from the internet on 9 January 2012 at http://www.population.gov.ng/index.php?option=com_content\&view=articl e\&id=211:nigerias-over-167-million-population-implications-andchallenges\&catid=1:latest-news 
Nigeria Tribune, (2010), Is SON Losing Fight Against Counterfeit Products?, 8 November, 2010, accessed from the internet on 9 November, 2010 at http://www.tribune.com.ng/index.php/industry/6394-is-son-losing-fightagainst-counterfeit-products

- (2011), Senate Rejects Justice Aderemi as ICPC Boss", 10 February, 2011, accessed from the internet on 10 February, 2011 at http://www.tribune.com.ng/index.php/news/17367-senate-rejectsjustice-aderemi-as-icpc-boss

- (2011a), Standardising SON, edition of 27 September, 2011.

- (2011b), Why Farida Waziri was sacked. Lamorde takes charge, holds meeting with ex-EFCC boss.

- (2011c), US okays Farida Waziri's sack: Backs Jonathan's moves to appoint 'strong candidate' for ICPC, 10 December, 2011.

Nkrumah, K., (1964), Consciencism, Monthly Review Press

NOI Polls, (2007), Perceptions of Effectiveness, Confidence and Corruption in Government Institutions and Agencies.

- (2008), Perceptions of Effectiveness, Confidence and Corruption in Government Institutions and Agencies.

- (2009), Perceptions of Effectiveness, Confidence and Corruption in Government Institutions and Agencies.

Nokkala, E., (2010), Passion as the foundation of natural law in the German enlightenment: Johann Jacob Schmauss and J.H.G. von Justi, European Review of History, Volume 17, No. 1, February 2010, pp. 113-123.

North, D. (1990), Institutions, Institutional Change and Economic Performance, Cambridge University Press.

Obasanjo, O., (1999), Inaugural Speech, downloaded from the internet on 20 March 2012 at http://maxsiollun.wordpress.com/2009/05/30/10thanniversary-of-nigeria\%E2\%80\%99s-return-to-democracy/ ). 
Obasi, E., (2010), Farida Waziri: Giving a dog a bad name, in Our Milestone, A Special Publication of Nigeria's Economic and Financial Crimes Commission, Vol. 1, No 1, May 2010, p.7

OECD, (2009), Measuring Government Activity, OECD Publishing

Olaopa, T., Olaopa, T. (2008), Theory and Practice of Public Administration and Civil Service Reforms in Nigeria, Ibadan: Spectrum

- (2009), Public Administration and Civil Service Reforms in Nigeria, University Press Plc, Ibadan.

- (2010), Public Service Reforms in Africa, University Press Plc, Ibadan.

Olowu, D. and Smoke, P., (1992), Determinants of success in African local governments: an overview, Public Administration and Development, Vol. 12, 117

Olowu, D., (2002), Public Service Delivery, in Adamolekun, L., Public Administration in Africa, Main Issues and Selected Country Studies, Spectrum Books.

Olsen, M., (1971), The Logic of Collective Action, Harvard University Press.

Olsen, M., Sarna, N., and Swamy, A., (1998), Governance and Growth: A simple hypothesis explaining cross-country differences in productivity, Mimeo, Centre for Institutional Reform and Informal Sector (IRIS), University of Maryland.

Oshana, D., (2006), Evidence-based Practice Literature Review, Prevent Child Abuse America, Chicago, Illinois. Downloaded from the internet on 5 January 2012 at http://member.preventchildabuse.org/site/DocServer/EBP_Literature_Revie w.pdf?docID $=162$

Ostrom, E., (2005), Understanding Institutional Diversity. Princeton University Press 
Owusu, F., (2005), On Public Organisations in Ghana; What Differentiates Good Performers from Poor Performers?, Development Policy Review, Vol.24, Issue 6, pp. 693-705

Parker, D., (1999), Regulation of Privatised Public Utilities in the UK: Performance and Governance, International Journal of Public Sector Management, 12(3), pp.213-235.

Paynter, R., (2009), Evidence-based research in the applied social sciences, Reference Services Review, Volume 37, Issue 4, pp.435-450.

Philippe, F., Vallerand, R., and Lavigne, G., (2009), Passion Does Make a Difference in People's Lives: A Look at Well-Being in Passionate and NonPassionate Individuals, International Association of Applied Psychology.

Piercy, N.F., Low, G.S. and Cravens, D.W., (2004), Examining the effectiveness of sales management control practices in developing countries, Journal of World Business, 39:255-267.

Pogoson, I., (2009), National Agency for Food and Drug Administration and Control: Managing the Crises in the Food and Drug Sector in Nigeria, Pockets of Effectiveness in Nigeria, unpublished, FES.

Prichard, W. And Leonard, D., (2010), Does reliance on tax revenue build state capacity on sub-Saharan Africa?, International Review of Administrative Sciences, 76(4), pp. 653-675.

Punch, (2012), EFCC Secures 500 Convictions in 12 Years, 25 February, 2012, downloaded from the internet on 1 March, 2012 at http://www.punchng.com/news/efcc-secures-500-convictions-in-12yrs/

Radio Netherlands Worldwide Internet,(2010), 'Made in Nigeria' actually 'Made in China', accessed from the internet on 9 November, 2010 from http://static.rnw.nl/migratie/www.radionetherlands.nl/africa/programmes/b ridgeswithafrica/090304-nigeria-made-in-china-redirected 
Radaelli, C., (2004), How Context Matters: Regulatory Quality in the European Union, paper prepared for PSA Conference, Lincoln, 5-8 April, 2004, Political Studies Association.

Ragin, C., (1987), The Comparative Method: Moving Beyond Qualitative and Quantitative Strategies, University of California Press.

- (2000), Fuzzy-set Social Science, University of Chicago Press

- (2008), Redesigning Social Inquiry: Fuzzy Sets and Beyond, University of Chicago Press.

Rainey, H., (1991), Understanding and Managing Public Organisations, JossyBass, San Francisco.

Rhodes, R., (1996), The New Governance: Governing without Government, Political Studies, XLIV. 652-667, p. 661.

Ribadu, N., (2010), My Story; My Vision, Youth Media and Communication Initiative.

Robbins, S., (1996), Organisational Behaviour: Concepts, Controversies, Applications, seventh edition, Prentice Hall, p.26

Rodney, W., (1972), How Europe Underdeveloped Africa, Panaf Publishing Inc.

Rodrik, D., (2003), In Search of Prosperity, Princeton University Press

Rodrik, D., (2005), Comments on Bolivia's CEM Annexe, accessed from the internet on 31 March, 2011, at http://siteresources.worldbank.org/INTPREMNET/Resources/489836$1123682017954 /$ comments bolivia rodrik.pdf

Rodrik, D., Subramanian, A. and Trebbi, F., (2004), Institutions Rule: The Primacy of Institutions over Geography and Integration in Economic Development, Journal of Economic Growth, Vol.9, Issue 2, pp. 131-165.

Rose-Ackerman, S., (2006), Corruption and Government: Causes, Consequences and Reform, Cambridge University Press. 
Rosen, S., (2007), Philosophy 101: Selections from the works of the Western World's Greatest Thinkers, Gramercy Books, New York, p. 487.

Sahara Reporters, (2008), Confusion Hits Nomination of New EFCC Boss as Senators Kick", 22 May 2008, accessed from the internet on 6 June 2011 at http://www.saharareporters.com/news-page/confusion-hits-nominationnew-efcc-boss-senators-kick

- (2011), N11.2m Fraud: AGF Stop Trial of Corrupt Minister", 31 January, 2011, accessed from the internet on the same day at http://www.saharareporters.com/news-page/n112m-fraud-agf-stoptrial-corrupt-minister?page $=1$

- (2011a), SERAP Asks Jonathan to Reinstate Acting ICPC Chairman”, 23 March 2011, accessed from the internet on the same day at http://www.saharareporters.com/press-release/serap-asks-jonathanreinstate-acting-icpc-chairman

- (2011b), Jonathan's Wife Responsible for Appointment of New ICPC Acting Chairman", 25 March, 2011, accessed from the internet on the same day at http://www.saharareporters.com/newspage/jonathan $\%$ E2\%80\%99s-wife-responsible-appointment-new-icpcacting-chairman-abang-wushishi-former-pdp

Sayer, A., (2010), Method in Social Science, Revised Second Edition, Routledge

Sharp, G., (2010), From Dictatorship to Democracy: A Conceptual Framework for Liberation, Fourth U.S. Edition, The Albert Einstein Institution.

Shaxson, N., (2007), Oil, Corruption and the Resource Curse, International Affairs, 83:6, pp. 1123-1140.

Shepherd, G., (2003), Civil Service Reform in Developing Countries: Why Is It Going Badly, Paper presented at the $11^{\text {th }}$ International Anti-Corruption Conference, May 2003, South Korea.

Siegel, H., (2006), Epistemological Diversity and Education Research: Much Ado About Nothing Much, Educational Researcher, Volume 35, Issue 2, pp. 312. 
Simmons, H., (2010), Case Study Research in Practice, Sage Publications Ltd.

Skocpol, T., (1985), Bringing the State Back in: Strategies of Analysis in Current Research, in Evans, P., Rueschemeyer, D., and Skocpol, T. (eds.), Bringing the State Back In, Cambridge University Press, Cambridge

Soest, C., (2009), The African State and Its Revenues: How Politics Influences Tax Collection in Zambia and Botswana, Nomos.

Stake, R., (1995), The Art of Case Study Research, Thousand Oaks, Sage.

Stiglitz, J., (1998), Private Uses of Public Interests: Incentives and Institutions, Journal of Economic Perspectives, 12(2), pp. 3-22.

Strauss, A. and Corbin, J., (1990), Basics of Qualitative Research: Grounded Theory Procedures and Techniques, Sage Publications.

Sturzenegger, F. and Tommassi, M., (1998), The Political Economy of Reform, Cambridge, MIT Press.

Sullivan, A. and Sheffrin, S., (2003), Economics: Principles in action, Pearson Prentice Hall

Sun, (2011), Stemming influx of substandard goods, 13 June 2011.

- Sun, (2011) Indeh: Customs Mr Welfare at 50, edition of June 2, 2011,

Sutherland, J., (2004), Should they de-Nobel Moniz?, The Guardian, accessed from the internet on 8 January 2011 at http://www.guardian.co.uk/education/2004/aug/02/highereducation.comme nt

Talbot, C., (2007), Performance Management, in the Oxford Handbook of Public Management, Edited by Ferlie, E., Lynn Jr., L. and Pollit, C., Oxford University Press. 
- (2008), Competing Public Values and Performance, in Holy Grail or Achievable Quest?: International Perspectives on Public Sector Performance Management, p.141, KPMG.

Tell, (2011), Special Publication: A Silent Revolution at the Revenue House, Tell Communications Limited

Tendler, J., (1997), Good Government in the Tropics, The John Hopkins University Press.

The Collins Paperback English Dictionary, (1991), Completely New Edition, Harper Collins Publishers, p. 669.

The Guardian, (2010), Corruption Index 2010 from Transparency International: find out how each country compares, accessed from the internet on 5 June, 2011 at http://www.guardian.co.uk/news/datablog/2010/oct/26/corruption-index2010-transparency-international

The News, (2011), A New SON, edition of 21 September, 2011.

Thelen, K., (1999), Historical Institutionalism in Comparative Politics, Annual Review of Political Science, 2:369-404.

This Day newspaper (2009), "UN Rates Nigeria Best in Drug Control", accessed from the internet on 9 November 2010 at http://www.thisdayonline.com/nview.php?id=143577

- (2009a), The Prevalence of Substandard Goods, edition of 30 September, 2009.

- (2011b), EFCC: Eight Years of Fighting Corruption, 11 April, 2011, p.25.

- (2011c), FG Begins Total Clampdown on Fake Products, edition of 3 May, 2011

- (2011d), Jonathan Nominates Elechi as ICPC Chair", 1 June 2011, accessed from the internet the same day at http://www.thisdaylive.com/articles/jonathan-nominates-elechi-as-icpcchair/92415/ 
- (2011e), ICPC...Toothless Bull-Dog After Eleven Years?", Lawyer, p.xi, March 29,2011.

- (2011f), SON: 60\% of Containers Enter Nigeria Without Inspection, 4 October 2011.

- (2011g), FIRS arrests FCDA Boss over 28 billion Unremitted Taxes, edition of Thursday 22 December 2011. Front page.

Thomson, W., (2004), Delivering Service in Nigeria: A Road Map, Office of Public Service Reforms, United Kingdom.

Transparency International, (Undated), Accessed from the internet on 7 May 2011 at http://www.transparency.org/news_room/faq/corruption_faq

- (2000), Corruption Perception Index, 2000, accessed from the worldwide web on 30 May 2010 at: http://www.transparency.org/policy_research/surveys_indices/cpi/prev ious_cpi/2000

- (2004), National Integrity Systems: Transparency International Country Report, Nigeria 2004.

United Nations International Narcotics Control Board, (2009), Report, United Nations.

United Nations Office on Drugs and Crime, (2008), Annual Report.

- (2009), NBS/EFCC Business Survey on Crime \& Corruption and Awareness of EFCC in Nigeria, 2007, SUMMARY REPORT.

Uphoff, N., Esman, M. and Krishna, A. (1998), Reasons for Success: Learning from Instructive Experiences in Rural Development, West Hartford, Conn: Kumarian Press.

USAID, (2006), Nigeria Economic Performance Assessment, 2006, downloaded from the internet on 1 March, 2012, at http://pdf.usaid.gov/pdf_docs/PNADF350.pdf

- (2006a), Anticorruption Agencies (ACAs), Anticorruption Programme Brief, Office of Democracy and Governance. 
Vallerand, R., Salvy, S., Mageau, G., Elliot, A., Denis, P, Grouzet, F., and Blanchard, C., (2007), On the Role of Passion in Performance, Journal of Personality, 75:3.

Van de Van, A., (1992), Suggestions for Studying Strategy Processes: A Research Note, Strategic Management Journal, 13 (summer special issue), pp. 169-188.

Vanguard, (2010), Money Laundering: EFCC has recovered \$11 bn, says FG, 12 December, 2010, downloaded from the internet on 1 March, 2012 at http://www.vanguardngr.com/2010/12/money-laundering-efcc-hasrecovered-11bn-says-fg/

- (2011), Odumodu to Unfold Agenda for SON, edition of February 16, 2011.

- $\quad$ ( 2011a), FIRS/NCS Introduce Importers Taxpayer's ID Number, edition of 7 November, 2011, downloaded from the internet on 14 March 2012 at http://www.vanguardngr.com/2011/11/firs-ncs-introduceimporters $\%$ E2\%80\%99-taxpayer\%E2\%80\%99s-id-number/ ).

- (2011b) Nigerians Hail Waziri's Removal, downloaded from the internet on 24 November, 2011at http://www.vanguardngr.com/2011/11/why-waziri-was-axednigerians-hail-removal/

Verbeeten, F., (2008), Performance Management Practices in Public Sector Organisations, Accounting, Auditing and Accountability Journal, Vol. 21 No 3, pp. $427-454$

Waal, A. de (2007), Is performance management applicable in developing countries? The case of a Tanzanian college, International Journal of Emerging Markets, Vo.2, No 1

- (2007), The Characteristics of a High Performing Organisation, Business Strategy Series, Vol. 8, No.3

- (2008), The Secret of High Performance Organisations, Management Online Review, April, 2008. 
Walmsley, G.L., and Zald, M.N. (1973), The Political Economy of Public Organisations. Lexington, Mass.: Heath.

Weick, K., (1989), Theory Construction as Disciplined Imagination, Academy of Management Review, Volume 14, No.4, pp.516-531.

- (1995), What Theory is Not, Theorizing Is, Administrative Science Quarterly, Volume 40, No. 3 (September 1995), pp.385-390.

Weiss, L., (2000), Globalization and State Power, Development and Society, Volume 29, No 1, pp. 1-15

Williamson, J., (2009), The Impact of the Global Financial Crisis on the Development Agenda, Peterson Institute for International Economics. Presentation to the World Bank Executive Directors on July 7, 2009, downloaded from the worldwide web on 29 May 2010 through http://www.iie.com/publications/papers/paper.cfm?ResearchID=1260

Williamson, O.E., (2000), The New Institutional Economics: Taking Stock, Looking Ahead, Journal of Economic Literature, 38, pp. 596-613

World Bank (1997), World Development Report: The State in a Changing World, Washington, World Bank.

- (2002), World Development Report, 2002: Building Institutions for Markets, Washington DC, World Bank.

- (2004), World Development Report: Making Services Work for Poor People, Washington, World Bank.

- (2010), World Governance Indicators, accessed from the internet at http://worldbank.org/governance/wgi/index.asp on 7 November, 2010.

- World Governance Indicators (2008 to 2010), accessed from the internet on 23 October, 2011 at http://info.worldbank.org/governance/wgi/mc_chart.asp

Yin, R.K., (2009), Case Study Research: Design and Methods, Fourth Edition, Sage Publications. 


\section{Summary in Dutch/ Samenvatting}

Ondanks de ontmoedigende institutionele uitdagingen, lukt het sommige organisaties in ontwikkelingslanden nog steeds om te leveren wat zij volgens hun mandaten moeten leveren. Veel van de literatuur over instellingen gaat ervan uit dat zwakke instellingen zullen leiden tot zwakke overheidsorganisaties. Veel staten worden nog steeds aangeduid als zwak en voorbeelden van sterke prestaties worden komen vaak van ontwikkelde landen. Het bestaan van 'eilanden van produktiviteit' in ontwikkelingslanden, in de literatuur steeds algemener erkend, tart deze bewering. Hoe en waarom zijn sommige organisaties in sommige staten, die over het algemeen als zwak aangemerkt worden, in staat institutionele uitdagingen te overwinnen en output te leveren? Dit is het onderwerp van dit proefschrift.

In de literatuur over 'eilanden van produktiviteit' in ontwikkelingslanden omschrijven veel auteurs over het algemeen de kenmerken die zij hebben gevonden in de door hen bestudeerde organisaties, die leiden tot produktiviteit. Deze kenmerken zijn vaak net zo van toepassing in staten met een sterk bestuur als in staten met een zwak bestuur. Ze omvatten onder andere leiderschap, loon, goede managementpraktijken, prestatiemanagement, duidelijkheid van verwachtingen en overheidssteun. Er wordt echter weinig geschreven over hoe de vereiste omstandigheden moeten worden gecreëerd en hoe tegengestelde institutionele omstandigheden worden overwonnen door deze instituten, om tot hun uitzonderlijk goede prestaties te komen.

Dit proefschrift behandelt meerdere casestudy's waarbij atypische prestaties op drie gebieden worden beoordeeld: anticorruptie, kwaliteit van regelgeving en omzetadministratie. Het boek bestaat uit negen hoofdstukken. Hoofdstuk 1 bepaalt de context van het onderzoek, beschrijft het fenomeen van sterke organisaties in zwakke staten, stelt de 
onderzoeksvraag en de afhankelijke en onafhankelijke variabelen vast en legt de benadering en het belang van het onderzoek uit.

Hoofdstuk 2 betreft een literatuur overzicht en hierin worden de theoretische concepten van staat, instellingen en overheidsorganisatie besproken. Ook wordt in dit hoofdstuk gepoogd de theorie te koppelen aan ervaring. Dit biedt een goede basis voor de empirische beoordelingen in het onderzoek. De betekenis van de staat en zijn rol wordt bekeken en het effect van globalisering op de macht van de staat wordt besproken. De staat op het Afrikaanse continent biedt de directe achtergrond voor het onderzoek, waarna wordt overgegaan op het bespreken van hoe organisaties in de publieke sector staten helpen hun rollen te vervullen. De literatuur over het onderwerp suggereert dat zwakke staten worden gekenmerkt door zwakke instellingen die op hun beurt weer zorgen voor zwakke organisaties. Sommige organisaties ontworstelen zich echter aan dit fatalistische beeld door toch goede publieke diensten te leveren. Daarom worden in het hoofdstuk de beperkingen van de huidige literatuur besproken. Het concept van het eisen van goede publieke diensten wordt gedifferentieerd van de verantwoordelijkheid van de vraagkant - de eerste omvat de wens, het vermogen, de macht en bereidheid voor betere levering van overheidsdiensten, terwijl de laatste zich meer richt op de wens zonder noodzakelijkerwijs de macht en het vermogen te hebben om het gewenste te realiseren. Ik heb het concept van vraag in groter detail bekeken, inclusief de verschillende mogelijkheden van verschillende spelers om vraag te stimuleren. Ik heb ook een raamwerk voorgesteld voor het beoordelen van de beschikbaarheid van de vraag. Het hoofdstuk wordt afgerond met de uitleg van het conceptuele raamwerk dat als basis diende voor het onderzoek.

Hoofdstuk 3 geeft een uiteenzetting van het ontwerp en de methodologische benadering van het onderzoek. Het laat de logische koppeling zien van de gegevens voor de ontwikkelende theorie van de vraag en hoe ik de bevindingen heb geïnterpreteerd. Tevens wordt de grondgedachte uitgelegd achter de keuze van kwalitatieve 
onderzoeksmethodes op basis van casestudy's en rechtvaardiging van de gekozen focusgebieden. Ten slotte beschrijft het hoofdstuk de gebruikte keuzemethodologie van de casestudy's, het plan voor de gegevensverzameling en de protocollen voor gegevensanalyse.

Hoofdstuk 4 tot en met 6 zijn de drie casestudy's in Nigeria waarop het empirische aspect van dit onderzoek is gebaseerd. Hoofdstuk 4 is de casestudy gericht op de Economic and Financial Crimes Commission en de Independent Corrupt Practices Commission. Hoofdstuk 5 is de casestudy over regelgevende kwaliteit gericht op de National Agency for Food and Drug Administration en Control and the Standards Organisation van Nigeria. Hoofdstuk 6 is de casestudy over inkomstenadministratie gericht op de Federal Inland Revenue Service en de Nigeria Customs Service. Iedere casestudy bevat een kort achtergrond- en geschiedenisgedeelte van de organisaties. Ik heb ook de literatuur bestudeerd behorend bij elke case en de belangrijkste hypotheses uit de literatuur geanalyseerd. Ook heb ik mijn eigen theoretische voorstellen ontwikkeld. Elke casestudy wordt afgesloten met een analyse van empirische gegevens en conclusies en bevindingen.

Hoofdstuk 7 is een cross-case analyse van de drie casestudy's ten opzichte van verschillende hypotheses en voorstellen. Hier worden de bevindingen van de empirische gedeeltes samengebracht en gezamenlijk beoordeeld ten opzichte van de hypothese en theorieën. Daarnaast wordt er gepoogd een hiërarchie te creëren van belangrijke factoren die leiden tot atypische prestaties in disfunctionele omgevingen.

In hoofdstuk 8 wordt de theorie van de vraag verder uitgebouwd en worden de hervormingspogingen gericht op de drie algemene gebieden.

Hoofdstuk 9 vormt de conclusie van het onderzoek met de beperkingen en mogelijke gebieden van toekomstig onderzoek.

Over het algemeen luidt de conclusie van het onderzoek dat sterke prestaties in de publieke sector in zwakke staten waarschijnlijker zijn in 
gebieden waar druk wordt uitgeoefend, de macht om veranderingen tot stand te brengen en de passie om die macht te gebruiken. Daarnaast wordt een aantal voorstellen in de huidige literatuur over het onderwerp bevestigd of betwist. 


\section{Curriculum Vitae \\ Joe Abah}

Joe Abah was born in Enugu, Nigeria, in 1964. He has worked in the field of governance reform most of his working life, except for a stint in legal practice at the beginning of his career. He was a pioneer member of Prime Minister Tony Blair's Office of Public Sector Reforms, and as a development consultant, has led, and still leads, a number of donor interventions on governance reforms in developing countries. He is married to Kemi and has two children (Nnenna, 18 years; and Olachukwu, 7 years).

\section{Recent Assignments}

- National Programme Manager, State Partnership for Accountability, Responsiveness and Capability, United Kingdom Department for International Development (DFID), Nigeria, 2011 to present.

- Deputy National Programme Manager, State Partnership for Accountability, Responsiveness and Capability, DFID Nigeria, 2009 to 2011.

- Programme Coordinator, Federal Public Service Reform Programme, DFID Nigeria, 2007-2009

- Federal Team Leader, State and Local Government Programme, DFID Nigeria 2005-2007.

- State Team Leader, State and Local Government Programme, DFID Nigeria, 2003-2005. 
- Senior Programme Manager, Prime Minister's Office of Public Service Reforms, United Kingdom, 2001-2003.

- Performance Manager, Audit Commission of England and Wales, 2001 to 2001

- Performance Manager, London Borough of Ealing, 1997-2001.

\section{Academic Record}

- Bachelor of Laws (Honours), University of Calabar, Nigeria, 1985

- Master of Arts (Business Law), London Guildhall University, London, England, 1992

\section{Professional Qualifications in Law}

- Certificate of Call to the Nigerian Bar (Barrister and Solicitor), Nigerian Law School, 1986.

- Admission Certificate (Solicitor), Law Society of England and Wales, 2002.

\section{Additional Professional Qualifications}

- Lead Auditor of Quality Management Systems (ISO 9000), 1995.

- Lead Environmental Systems Assessor (ISO 14001)

- Lead Assessor and Licensed Trainer, EFQM Excellence Model, 2000. 


\section{Maastricht Graduate School of Governance Dissertation Series}

\section{Zina Nimeh}

Social Citizenship Rights - Inequality \& Exclusion

MGSOG Dissertation Series, nr 27 (2012)

\section{Lenka Eisenhamerová}

Legitimacy of 'Humanitarian Military Intervention'

MGSoG Dissertation Series, nr 26 (2011)

\section{Sonila Tomini}

Informal Payments for Health Care Services in Albania

MGSoG Dissertation Series, nr 25 (2011)

\section{Jinjing Li}

Dynamic Microsimulation in Public Policy Evaluation

MGSoG Dissertation Series, nr 24 (2011)

\section{Aziz Atamanov}

Rural Nonfarm Employment and International Migration as Alternatives to Agricultural Employment: The Case of Kyrgyztan

MGSoG Dissertation Series, nr 23 (2011)

\section{Frieda Vandeninden}

Poverty Alleviation: Aid and Social Pensions

MGSoG Dissertation Series, nr 22 (2011)

\section{Juliana Nyasha Tirivayi}

The Welfare Effects of Integrating AIDS Treatment with Food Transfers: Evidence from Zambia MGSoG Dissertation Series, nr 21 (2011) 


\section{Agnieska Ewa Sowa}

Who's Left Behind? Social Dimensions of Health Transition and Utilization of Medical Care in Poland

MGSoG Dissertation Series, nr 20 (2011)

\section{Emmanaouil Sfakianakis}

The Role of Private Actors in the Provision of Public Goods with Applications to Infrastructure and Financial Stability MGSoG Dissertation Series, nr 19 (2011)

\section{Siu Hing Lo}

White Collars Green Sleeves: An Interonganizational Comparison of Deteminants of Energy-Related Behaviors among Office Workers MGSoG Dissertation Series, nr 18 (2011)

\section{Treena $\mathbf{W u}$}

Constraints to Human Capital Investment in Developing Countries: Using the Asian Financial Crisis in Indonesia as a Natural Experiment

MGSoG Dissertation Series, nr 17 (2011)

\section{Henry Espinoza Peña}

Impact Evaluation of a Job-Training Programme for Disadvantaged Youths: The Case of Projoven MGSoG Dissertation Series, nr 16 (2011)

\section{Florian Tomini}

Between Family and Friends: Understanding the Interdependency of Private Transfers MGSoG Dissertation Series, nr 15 (2010)

\section{Michał Polalowski}

The Institutional Transformation of Social Policy in East Central Europe MGSoG Dissertation Series, nr 14 (2010)

\section{Maha Ahmed}

Defining, Measuring and Addressing Vulnerability: The Case of Post Conflict Environments MGSoG Dissertation Series, nr 13 (2010) 


\section{Pascal Beckers}

Local Space and Economic Success: The role of spatial segregation of migrants in the Netherlands

MGSoG Dissertation Series, nr 12 (2011)

\section{Victor Cebotari}

Conflicting Demands in Ethnically Diverse Societies- Ethnopolitical Contention and Identity Values in Europe MGSoG Dissertation Series, nr 11 (2010)

\section{Dennis Gyllensporre}

Competing and Complementary Perspectives on the EU as a Crisis Management Actor: An Examination of the Common Security and Defence Policy through the Lenses of Idealism and Realism

MGSoG Dissertation Series, nr 10 (2010)

\section{Judit Vall Castello}

Business Cycle and Policy Effects on Labour Market Transitions of Older and Disabled Workers in Spain

MGSoG Dissertation Series, nr. 9 (2010)

\section{Keetie Roelen}

False Positives or Hidden Dimensions: the definition and measurement of child poverty

MGSoG Dissertation Series, nr. 8 (2010)

\section{Denisa Maria Sologon}

Earning Dynamics in Europe

MGSoG Dissertation Series, nr. 7 (2010)

\section{Melissa Siegel}

Money and Mobility: Migration and Remittances

MGSoG Dissertation Series, nr. 6 (2010)

\section{Jessica S. Hagen-Zanker}

Modest Expectations: Causes and effects of migration on migrant households in source countries

MGSoG Dissertation Series, nr. 5 (2010) 


\section{Mirtha R. Muniz Castillo}

Human Development and Autonomy in Project Aid: Experiences from four bilateral projects in Nigaragua and El Salvador

MGSoG Dissertation Series, nr. 4 (2009)

\section{Christiane Arndt}

Governance Indicators

MGSoG Dissertation Series, nr. 3 (2009)

\section{Britta Augsburg}

Microfinance - Greater Good or Lesser Evil?

MGSoG Dissertation Series, nr. 2 (2009)

\section{Geranda Notten}

Measuring and Managing Poverty Risks

MGSoG Dissertation Series, nr. 1 (2008) 